\title{
From directions to descriptions: Reading the theatrical Nebentext in Ben Jonson's Workes as an authorial outlet
}

\author{
David J. A melang \\ Freie U niversität Berlin, Germany
}

\begin{abstract}
This article explores how certain dramatists in early modern England and in Spain, specifically Ben Jonson and Miguel de Cervantes (with much more emphasis on the former), pursued authority over texts by claiming as their own a new realm which had not been available-or, more accurately, as prominently available - to playwrights before: the stage directions in printed plays. The way both these playwrights and/ or their publishers dealt with the transcription of stage directions provides perhaps the clearest example of a theatrical convention translated into the realm of readership.
\end{abstract}

KEYWORDS: William Shakespeare; Ben Jonson; Lope de Vega; Miguel de Cervantes; stage directions.

\section{De indicaciones a descripciones: la lectura del $\boldsymbol{N}$ ebentext teatral en las Workes de Ben Jonson como expresión autorial}

RESUMEN: Este artículo analiza cómo ciertos dramaturgos en las Inglaterra y España del Renacimiento, especialmente Ben Jonson ( $\mathrm{y}$ en menor medida también Miguel de Cervantes), buscaron establecer su posición autorial sobre sus textos de una manera no disponible hasta ese momento (o al menos no tan claramente disponible) para escritores de teatro: en las acotaciones escénicas de las versiones impresas de sus obras. La manera en la que ambos dramaturgos y/ o sus impresores manejaron la transcripción de acotaciones es un gran ejemplo de ciertas costumbres del mundo actoral adaptadas para un público lector.

PALABRAS CLAVE: William Shakespeare; Ben Jonson; Lope de Vega; Miguel de Cervantes; acotaciones.

\section{De indicações a descrições: ler o Neben- text teatral em Workes de Ben Jonson como expressão autoral*}

RESUMO: Este artigo explora de que forma certos dramaturgos em Inglaterra e na Espanha do Renascimento, especificamente Ben Jonson e Miguel de Cervantes (com maior ênfase no primeiro), procuraram estabelecer uma posição autoral sobre os seus textos ao reclamarem para si uma área que anteriormente não estava disponível-ou, de forma mais correta, não tão claramente disponível-para dramaturgos: as didascálias de peças impressas. A forma como estes dois dramaturgos e/ ou os seus editores lidaram com a transcrição de didascálias fornece-nos talvez o mais claro exemplo de uma convenção teatral traduzida para um público leitor.

PALAVRAS-CHAVE: William Shakespeare; Ben Jonson; Lope de Vega; Miguel de Cervantes; didascálias.

\footnotetext{
${ }^{*}$ Translation into Portuguese by Miguel Ramal hete.
} 
The early modern era was a period in history during which theater and literature did not necessarily enjoy the metonymic relationship they often do today. A playbook was understood to be a transcription of a theatrical performance. R. B. McKerrow best explains the logic behind this position when he says that an Elizabethan play manuscript "was not a literary document at all. It was merely the substance, or rather the bare bones, of a performance on the stage, intended to be interpreted by actors skilled in their craft, who would have no difficulty in reading it as it was meant to be read" (1931, 266). Only after the play was performed and published, John Jowett points out, could the comprehension of playtexts evolve from being considered strictly dramatic texts into becoming literary texts as well: "we now usually understand that Shakespeare plays originated as (primarily) dramatic texts and became (primarily) literary texts. Hence, even in our literary readings, we find it appropriate to recuperate an understanding of the script's dramatic aspect" (2007, 148-49).

In an attempt to travel back in time in order to understand better the original circumstances of play production, one of the most commonly considered subjects of analysis is the early modern notion of authorship. Many people were involved in putting on a single commercial theater performance. The same was the case when composing a play. There were the plotters who wrote the skeleton of the play; then the playwright (or playwrights, as they were often hired in numbers) gave textual flesh to the skeleton; if necessary, ancillary artists would write specialized material (for example musicians and their songs); and stage functionaries would often add performance-specific notes such as the stage directions. Even before arriving at the printing house, in which some manipulation could also be expected (whether accidental, incidental or on purpose), in England writing drama was understood to be a collaborative process (Stern 2009, 1-7). As much as any other artistic manifestation, an early modern playbook was the product of the period's social and cultural energy in circulation. For this reason, the question of the authorship of plays has always been very present in early modern literary scholarship, even if originally its purpose was to peel off the non-Shakespearean layers in the plays.

Considering all the people who intervened in the process of making theater, as well as the complex notions of copyright of the 
period (Rose 1993; Loewenstein 2002), it was difficult for a single agent to claim authority and authorship over the staged play. Logically, the playbook, if understood as a post-script record of the performance, could not offer any more channels through which the playwright(s) could assert his (their) voice. However, early modern playwrights seemed to have been aware that a play could have an existence beyond ephemeral performance: the inclusion of explanatory paratext, added passages that had not been performed before (or so many printers claim), or plays that were quite obviously never meant to be taken to the stage. Clearly, the concept of drama as something beyond just scripted performance was slowly gaining ground in the early modern consciousness, and therefore the profession of dramatist was at a crossroads between being a commercial playwright and a dramatic author. ${ }^{1}$

Here the term "drama" is intentionally used to contrast with "theater." The dramatic work, unlike the theatrical text, allowed one or more playmakers to assert their voices over the rest and claim authorship over the product. In a sense, the page was a better locus wherein to exert one's individual authority than the much more collaborative stage. However, there were very few playwrights directly involved in the publication process of their own plays, and consequently only few seem to have taken advantage of this possibility. Without a doubt, the most conspicuous dramatist, demanding full and unquestionable recognition of his distinctive voice, was England's Ben Jonson. It is well known that Jonson was heavily invested in the printing of his work so as to allow as little external intrusion as possible. For instance, after being hired as one of the playwrights to give shape to the plot of Sejanus (a plot he himself had written), when the play was to be released commercially in print in 1605 he rewrote the passages written by other play-patchers to make the final work "unmistakably his own" (Dutton 1983, 54; Stern 2009, 25-27). Later, in 1616, Jonson commissioned and supervised

\footnotetext{
${ }^{1}$ Linda Mcjannet postulates that "the rhetoric of title pages and prefaces suggests that the Elizabethans deemed playscripts from the theater as adequate and appropriate for the lay reader" $(1999,25)$. One very clear example of how a playtext could be prepared for the reader comes from Spain's Juan de la Cueva and the publication of his collected works: the second edition (1588) provides argumentos (brief summaries, similar to the English plots described by Tiffany Stern in 2009, 8-35) for each play and act that the first edition (1582) did not, very probably the author or publisher's effort to make the new release more reader-friendly.
} 
the publication of a folio compilation of many of his texts, dramatic and non-dramatic, with which he managed to fashion himself as both a stage playwright at the service of a theater entrepreneur and a page author defending his writing as individual art.

In varying degrees most critics agree that, through his Workes, Jonson "broke with the traditional practice which transferred the ownership of the plays to the company as if their real 'authors' were the directors of the companies and not the playwrights" (Chartier 1999, 53-54). N ora Johnson calls to mind that "his productions, even for 'the loathed stage', were, he famously insisted, recuperable as high literature, as works, while the contributions of less distinguished playwrights remained popular entertainment, unworthy of a court poet and learned author" $(2003,54)$. By actively taking control and unifying all the domains of textual artistry under a single authority, the playwright slowly raised his status from being a hired artisan of the playground to being a literary author of dramatic texts. ${ }^{2}$ This article explores the slow yet visible transformation that took place in the profession of the playwright as a consequence of the rise in popularity of the printed playbook. It also argues that Jonson enhanced his authority over his texts by claiming for his own a new realm which had not been available (or, more accurately, as prominently available) to playwrights before: the stage directions in printed plays. In particular, it focuses on the way Jonson dealt with the transcription of stage directions, as providing perhaps the clearest example of a theatrical convention translated into the real $m$ of literature.

$\infty 28$

\footnotetext{
${ }^{2}$ As Richard Barbour indicates, the idea of the author Jonson fashioned for himself with the W orkes was still one of an artisan of words; however, unlike the labor of the playwright, Jonson's self-fashioning as a dramatic author allowed him to present his work as the product of a single independent individual. "Developing arguments by Stallybrass and White," Barbour writes, "that Jonson negotiated 'an emergent place for authorship at a distance both from the aristocracy and the plebeians,' and Haynes, that Jonson tenaciously 'stuck to a middle-class identity,' I want to propose that artisanal pride in the craft of poetry was crucial to that negotiation of a middle space. To see poetic making as labor and to valorize that labor, helped Jonson to define himself against a courtly ethos of easeful mastery and find his way to an independent poetic identity" $(1998,505)$.
} 
In Das literarische Kunstwerk ([The Literary Work of Art], 1931), Roman Ingarden distinguishes between two types of texts that can be found in a dramatic piece: the Haupttext, or main text, and the N ebentext, which translates into English as "adjacent text" $(1972,208-$ 22). More recently, Manfred Pfister also discusses the coexistence of two types of textual layers in the dramatic work: "One layer comprises the spoken dialogue that takes place between the dramatic figures, whilst the other refers to the verbal text segments that are not reproduced in the spoken form" (1988, 13-14). Pfister's "secondary text" level coincides with Ingarden's N ebentext, those "features that distinguish drama from a genre such as prose fiction", as Margaret Jane Kidnie explains, "the most important being stage directions" $(2000,460){ }^{3}$

Stage directions are unique types of textual information exclusive to, and to a certain extent defining of, the theatrical genre. They are the non-verbal complementary elements that, when put together with the lines of the characters, complete the picture and permit lay readers to see as well as hear what is happening. The more selfsufficient the $\mathrm{H}$ aupttext is, by means of deictic references and other forms of description, the fewer stage directions are needed; the barer the Haupttext is, the richer the $\mathrm{N}$ ebentext must be in order to guarantee a minimum standard of clarity. Despite the essential weight they carry in a theatrical text, stage directions until the Renaissance were not as important as we consider them nowadays. In fact, in ancient Greek and Roman drama almost all non-verbal action that takes place on stage is implied in the dialogue and consequently there are very few surviving instances of $\mathrm{N}$ ebentext (Mcjannet 1999, 9). By Shakespeare's time, stage directions were minimal and minimalistic, but had nevertheless become indispensable. The studies on stage directions in early modern English drama carried out by Alan Dessen and Leslie Thomson (who co-wrote their seminal A Dictionary of Stage Directions in English D rama 1580-1642) claim that the nebentextual stage directions are transcriptions of a specific dialect common to all theater practitioners-the "theatrical vocabulary," Dessen terms it-and that

\footnotetext{
${ }^{3}$ Pfister goes on to list the different forms of secondary texts, which include "the title of the play, the inscriptions, dedications and prefaces, the dramatis personae, announcements of act and scene, stage-directions, whether applicable to scenery or action, and the identification of the speaker of a particular speech" $(1988,14)$.
} 
"in reading one of the early printed texts of a Shakespeare play, we enter in the middle of a conversation-a discourse in a language we only partly understand-between a dramatist and his actorcolleagues" (1995, 5; Ichikawa 2013, 17-25). This idea of lay readers "eavesdropping" on a jargon-ridden dialogue among playhouse professionals fits in well with Grace Ioppolo's (2006) theory that theatrical manuscripts were written and rewritten by playwrights working in close quarters with acting companies, which recently received substantial support from Paul Werstine's (2012) reappraisal of New Bibliography's ideas that underlined most of twentiethcentury early modern manuscript studies; and Tiffany Stern's (2009) work on the paper trail of the early modern English playhouse also allows for such a scenario.

A brief summary of the research carried out so far on the "theatrical vocabulary" of early modern stage directions in printed playbooks is that they are, for the most part, brief and unadorned. An entry would be marked with "Enter [character]," perhaps with a short tag addressing the place from where the characters emerge or in which fashion they do so. Exits appear in identical style, sometimes using the Latin "exeunt" instead of the vernacular for when a group leaves, a trace of the dying preference for using Latin as the traditional $\mathrm{N}$ ebentext language. Since indicators of action, gesture and special effects were rare, the codification was not completely uniform, but that in no way prompted a lengthier and more elaborate diction than that found in other directions. In short, the logical tendency is to think that in the early modern era the writers of the performance instructions-they are for the most part written in an imperative tone-were not the same writing the stage poetry. Even in those cases in which an unusual or idiosyncratic use of certain words or expressions may suggest that the playwright himself was writing his own stage directions, these are still written in the dialect specific to stage professionals.

This is not only found in English public theater: in Golden Age Spain the practice of codifying stage directions for commercial performances was exactly the same. Victor Dixon, writing from the point of view of seventeenth-century autor de comedias Manuel Vallejo, summarizes it best:

The golden rule our poetas stick to is that, when preparing a manuscript such as this one [supposedly the playhouse copy for the 
first performance of Lope's El castigo sin venganza], they do not add anything other than the words we actors will end up reciting. [...] Sometimes-although not always-the playwright will mark the entrances and exits of characters. Maybe he will add directions regarding props, wardrobe and accessories, the positions and blocking of the actors, their nuances and gestures. Some other times he finds a clever way of presenting some of these things without actually saying them. [...] But in most cases he will add nothing at all, not simply because he trusts us players, but because he knows we will al ways find a way to make the text work and the audience understand it. (Dixon 1989, 56 [my translation])

Perhaps Dixon wrote this passage with the 1631 autograph manuscript of El castigo sin venganza currently located in the Boston Public Library (Ms. D.174.19) in mind. This authorial foul copy of Lope's late tragedy, full of blotted lines and metric aids there only for the benefit of the poeta, also contains a fair number of stage directions. The considerable number of surviving autograph manuscripts of Golden Age Spanish plays suggests that playwrights in Lope's age may have been more involved in writing the $\mathrm{N}$ ebentext than Dixon suggests; and, in the light of such evidence, hypotheses regarding playwriting practices in early modern England's theatrical culture may also warrant reconsidering. ${ }^{4}$ Lope's acotaciones, as stage directions are known in Spanish, are not marginal (here meant both literally and figuratively) afterthoughts inserted into the manuscript during a playhouse rehearsal: Lope writes them as part of the main text, heralded in the margins with a cross and separated from the characters' dialogue by long horizontal lines (the convention of the time), yet clearly an integral part of the playwright's storytelling sequence. Despite being the author, Lope does not take advantage of his position and keeps his acotaciones within conventional expectations. As Dixon explains, they are not elaborate or literary notes, and for the most part limit themselves to providing information needed to understand and/ or stage the play. Lope writes these stage directions in the Spanish equivalent of Dessen and Thomson's "theatrical language." The stage directions in the first printed editions of the EI castigo sin venganza appear exactly as Lope

\footnotetext{
${ }^{4}$ For further research regarding Spanish Golden Age theater manuscripts, see the online database project M anos Teatrales [http:/ / www.manos.net] led by Margaret Greer and Alejandro García-Reidy (further reading on the $M$ anos project in Greer 2009, 262-66; 2012). My thanks to Margaret Greer and Alejandro García-Reidy for all the help and guidance with this field.
} 
handwrote them himself. In fact, had this manuscript not been conserved properly, we might have thought that it was some stage hand or amanuense writing Lope's uninspiring acotaciones (Vega 1634; Vega 1635, 91r-113v).

That said, one cannot honestly portray the style of stage directions in early modern drama as completely bare, static or stagnant. As alluded to above, at the brink of becoming considered "high literature," the N ebentext of the early English playbook also adapted to favor of its new form of consumption. Mcjannet's research on the evolutionary process of stage directions shows that the Elizabethan stage direction were at a transitional point between being openly self-conscious of its role as a theatrical instrument and being somewhat more literary and part of the fictive world, without trying to shatter the illusion altogether:

Whether textually or theatrically aware, self-conscious directions address their interpreters from a position outside the world of the play. They address themselves directly to their interpreters as readers of "words," "lines," or other textual elements, or as producers of a play concerned with theatrical illusion and the time and space of performance. Self-effacing directions, on the other hand, though still clearly distinct from the dialogue, do not address their interpreters directly; they operate within the theatrical illusion and the fictive world of the play. [...] The practice of any theatrical community is rarely purely one or the other, but, in general, stage directions in English plays move from self-consciousness in the medieval period to relative self-effacement in the late sixteenth and early seventeenth centuries, particularly in plays for the professional London theaters. (McJannet 1999, 111-12)

It is difficult to see this transformation of the self-conscious into the self-effacing stage directions of a Shakespeare or a Marlowe play. ${ }^{5}$

\footnotetext{
${ }^{5}$ In large part this has to do with the fact that the stage directions in the works of these playwrights are thought to have been written by a different playhouse agent. It would make no sense to begin a discussion about literary self-effacement in the performance notes of stage practitioners who had no ulterior motive in writing anything beyond the essential for the preparation of the show. However, Grace loppolo's study of the surviving autograph manuscripts of early modern English playwrights (2006, 157-62) suggests that the stage directions written by the playwrights themselves did in fact have a different quality from those written by playhouse personnel, even if "selfeffacing" may not be the right word; she points out that many of the authorial stage directions contain mistakes and show inattention to staging details, signals of "a composing author at work, not primarily concerned about such details in the throes of composition and thus slightly and momentarily confused about who is, and is not, on
} 
On the other hand, the conversion of the $\mathrm{N}$ ebentext in the printed W orkes of Ben Jonson, a self-proclaimed author and descendant of the great poets of Antiquity, from the jargon of the professional playmakers into a less technical style for the benefit of the lay reader is much more visible. ${ }^{6}$ The juxtaposed study of the quarto versions of Jonson's plays and their folio counterparts helps highlight certain aspects of this transition of styles, especially since any observations made are underlined by the prevailing narrative of Jonson's having been highly invested in the arrangement and printing of his 1616 compilation.

One aspect that all the plays in the folio have in common is that the $\mathrm{N}$ ebentext differs significantly from the ancillary text in their earlier quarto versions. Starting with the act and scene indicators (and even the paratextual prologue), which Jonson translated from the Latin "actus," "scena" and "prologus" into the vernacular, these modifications seem to be aimed at distancing the Workes from the "theatrical vocabulary" and the conventions associated with the playhouse. Much more significant is the different treatment given to stage directions. Many of the original quarto editions contain no stage directions, as is the case of $\mathrm{V}$ ol pone. A possible explanation for the lack of performance indicators is that the copy of the play submitted to the printer had not been used for rehearsals, during which the theater professionals (often in accordance or with the help of the playwright [M cjannet 1999, 9-23]) agreed on the final blocking and staging; this practice would thus highlight the collaborative effort that was playmaking already in its primal kinetic form. Alternatively, one can read the frequent lack of stage directions in Jonson's quartos as the playwright's effort to differentiate the play he wrote from the performance he-along with others-scripted by

stage." For example, the manuscript stage directions for the dumb shows in Middleton's H engist, King of Kent are syntactically more fleshed out than the average Jacobean bare-boned dumb show description. While the two surviving manuscripts of the play are not in Middleton's own hand (they are scribal copies, presumably commissioned as a gift for an aristocratic patron), Ioppolo explains that they should be considered "authoritative texts because of their overwhelming agreement in spelling, diction, directions, character names, and speech prefixes, their evident dependence on Middleton's unique spelling and scribal practices" (2007, 1056-61).

${ }^{6}$ Many scholars have previously noted the uniqueness of Ben Jonson's stage directions, for which Alan Dessen and Leslie Thomson reserve a lengthy aside in the introduction of their dictionary (2001, xii-xiii). 
presenting the text in the fashion of the early humanist editions of the classics. ${ }^{7}$ However, for the folio version of the play Jonson inserted descriptions of the characters' actions. For instance, in the second scene of the first act the margin of the page read "O ne knocks without" (1616, 454), signaling the first of many visitors Volpone would receive that day; there is no such direction in the quarto edition (1607, B3v). The same happens later on when Celia "at the windo' throwes downe her handkerchiefe" $(1616,471)$, an action that goes unremarked in the 1607 text (E2v), making it seem as if she had silently turned down Volpone's petition of her favor. The same can be said of the rest of the play, and a few others as well; other quarto versions of Jonson's plays lacking stage directions that later appeared in the folio are Sejanus (1605), Catiline (1611) and The A lchemist (1612).

Other Jonson quartos, for instance the 1602 Poetaster edition, do have stage directions, but these are written in the conventional fashion of the directions described by Dessen's notion of "theatrical vocabulary." Limited almost exclusively to entrances and exits, the $\mathrm{N}$ ebentext of the Poetaster quarto has every indication of having been designed by or with the stage practitioners-and only the stage practitioners-in mind. The folio text replaces most of the plain exit markers with more elaborate versions of the same thing. For instance, in the first scene of the second act Jonson changed Albius' continuous Exits (1602, C2-C2v) for a more elegant " $\mathrm{He}$ is still going in and out" (1616, 288). At a later point, a plain and conventional "Exeunt" (1602, F3) is substituted by "They with-draw to make themselues ready" (1616, 306), providing more detail and nuance to aid the reader to follow the action better. In many other cases the original playhouse directions are simply removed altogether without any form of replacement, reinforcing the hypothesis that Jonson thought impersonal theatrical $\mathrm{N}$ ebentext was not worth becoming part of his literary monument. Two other of his earlier quartos, Every $M$ an In his Humour (1601) and Cynthia's Revels (1601) underwent similar alterations when revisited for the preparation of the 1616 folio.

\footnotetext{
${ }^{7}$ Revels editors Brian Parker and David Bevington take for granted that the quarto edition of V olpone "was set up from a fair copy prepared by Jonson himself, with no theatrical influences; and, like some previous Jonson quartos, it has been consciously modelled on the format of the early humanist editions of the Latin dramatists Plautus and Terence, with massed entries at the beginning of each scene and few indications of when characters are to exit" (1999, 24).
} 
The oddity among the quarto-turned-folio plays is the earliest of them all, Every M an Out of his Humour (1600). This edition seems quite clearly to have been a version of the performance script that Jonson later adapted for the medium of print, and which already hinted at some of his extra-theatrical aspirations. The title page warns the reader that this text contains "more than hath been Publickely Spoken or Acted" (1600, A), a quite common marketing strategy for printed playbooks at the time. Although there is a lingering presence of theatrical practice in this edition, a lot of the stage is lost in the play's translation to the page. For example, the convention of writing the directions in a pseudo-imperative tone is still quite strong, although one can see an obvious attempt on Jonson's behalf to prosify the $\mathrm{N}$ ebentext and make it more readerfriendly. The folio's taking the next step by adding new directionsits "H e leaps from whispring with the boy" towards the beginning of the second act $(1616,102)$ cannot be traced to the quarto-is one of such several instances. Even more interesting is that Jonson took his time to convert the pseudo-imperative orders for the players into narrative descriptions for the reader. He replaces the original "Enter Carolo Buffone, with a Boy" one finds in the prologue (1600, Cv) with "H e enters with a Boy, and wine" $(1616,88)$. A gain, early in the first act Jonson changes another conventional entrance like "Enter a $\mathrm{H}$ ine to Sordido with a Paper" $(1600, D 3)$ into "The Hine enters with a paper", and so on $(1616,96)$.

These examples, especially the last one, suggest that one cannot doubt Jonson's desire to include this form of text as part of his pursuit of something new. Even though for the most part stage directions "are, more than any other part of a playbook, written by theatre practitioners, or at least with them in mind" (Stern 2009, 227), I believe that Jonson clearly ended up taking over and writing (or rewriting) them himself for the benefit of the reader of his playbook. Moreover, he did so in such a personal, distinct way that they can and should be understood as part of the Jonson literary corpus, no longer a remnant of the theatrical event, but lines written specifically by the playwright and thus retaining authorial integrity. Indeed, in the folio-whose printing arrangement confined the stage directions to the margins of the main text-he is very visually taking over a space of the theatrical script that was not expected to be part of the playwright's domain, or at least not in his voice. He went a step further than simply "refashioning his play for a reader", in Dessen 
and Thomson's words (2001, ix). As the case of Every $M$ an $O$ ut of his Humour shows, Jonson made a conscious effort to alter the default "theatrical language" directions into something different, less selfevident and more self-effacing, something he thought-or knewworked better with his intended readership. But even if the purpose behind introducing his authority into the $N$ ebentext may never be completely known to us-Holger Schott Syme's idea that Jonson was trying to find "a way of making the book a theater", instead of making the theatrical transcript a book, is quite enticing $(2008,144)$ we can still delve quite freely into the possible sources from which Jonson took inspiration to make such changes. The final section of this article explores a possible influence of Jonson's career as a writer of court masques on the way he ended up dealing with the $\mathrm{N}$ ebentext of his commercial plays.

(2)

In the latter half of the twentieth century, Golden Age Spanish scholarship took a much stronger interest in the previously neglected dramatic works of Miguel de Cervantes. The author of novels and novellas was finally acknowledged as a playwright of note, even if his theater had been met by his contemporaries with mild disinterest at best. In 1615, capitalizing on the success of his narrative works, Cervantes released a volume containing eight plays and eight entremeses in what has been interpreted as "an extreme response against what he thought was an injustice" done to his dramatic oeuvre (Profeti 1999, 60-64 [my translation]). They are profoundly un-Lopean, which may explain why they were not successful with the crowds flocking day in and out to comedia nueva shows. One of the aspects most critics immediately noted was that the stage directions in this collection were quite unlike the typical acotaciones of most plays in this period. They were longer and more fleshed out-more narrative, one could say-than the brief and uninteresting directions that were the norm in the comedias of the time. In the quest to provide a reason for such unusual notations, John Varey turned to other Cervantine works as a possible source of inspiration: the author "seems to confound the art of writing plays and the art of writing novels" (as cited in Profeti 1999, 62 [my 
translation]). ${ }^{8}$ Whether through logic or simply due to the welldeserved omnipresence of Don Quijote in everything written by Cervantes, Varey puts forth the notion of the author's skillset flowing seamlessly from one written genre into another. This theory, though difficult to prove, is too commonsensical to be dismissed for lack of evidence. I would suggest that something similar may have happened with Ben Jonson, who was a commercial playwright, writer of pageants and court masques, and wrote texts in a variety of fields. The fact that both commercial plays and court masques belong to the same dramatic genre renders the hypothesis of a transference of styles from one textual form to the other even more plausible.

When Jonson began his career as a playwright in the late sixteenth century, there was no single way of presenting stage directions in a printed playbook. "Consistency is the exception, not the rule", Jowett reminds us (2007, 149). However, there was a big difference in the treatment of the $\mathrm{N}$ ebentext of a commercial playbook and that of one of the other main forms of scripted performance: the masque. A masque, or mask, was "a spectacular kind of indoor performance combining poetic drama, music, dance, song, lavish costume, and costly stage effects, which was favoured by European royalty in the $16^{\text {th }}$ and early $17^{\text {th }}$ centuries" (Baldick 2004, 148), and Jonson was the preeminent writer of masques for the court of James I. The 1616 folio compilation of his dramatic and poetic writings included nineteen masques, the final 122 pages of the 1015-page volume, a clear sign of how crucial they were to his body of work. These masques paid much attention and placed much emphasis on the elaboration of the $N$ ebentext. Here is an extract from The $M$ asque of Blackness, first performed by Queen Anne and her entourage at Whitehall in 1605 and considered to be one of Jonson's earliest masques, if not the first:

the Moone was discouered in the vpper part of the house, triumphant in a Siluer throne, made in figure of a Pyramis. Her garments White, and Siluer, the dressing of her head antique, \& crown'd with a Luminarie, or Sphere of light: which striking on the clouds, and heightned with Siluer, reflected as naturall clouds do by the splendor of the Moone. The Heauen, about her, was vaulted with blew silke, and set with Starres of

\footnotetext{
${ }^{8}$ A gustín de la Granja also discusses Cervantes' long and atypical stage directions in the 0 cho comedias y ocho entremeses collection (1989, 106-109).
} 
Siluer, which had in them their seuerall lights burning. The suddaine sight of which, made Niger to interrupt Oceanvs, with this present passion. (Jonson 1608, B3)

It is obvious that this style of stage direction, which is not particularly remarkable either in style or in length compared to the rest of the masque's $N$ ebentext, has little or nothing to do with the average directions in a popular theater playbook, and at no point in his career does Jonson try to transfer it from one medium to the other. If anything, more of the speech-based popular playwriting made it into his masques than the other way around. Marijke Rijsberman points out that the early masques "tend to rely on gestural, as opposed to verbal, signification to a far greater degree $[\ldots]$ and it is the gesture which is given the function of bridging the gap between the masque and its context" (1987, 224); eventually, although words "never over-balanced their fellow-ingredients, music, dance, and spectacle", Jonson's masques did become progressively more speech heavy (Adams 2001, xiv). But from the perspective of the $\mathrm{N}$ ebentext, especially in the added or altered stage directions of the folio, much can be said about how his experience as a masque writer influenced the presentation of his commercial plays in print. Moreover, seeing the significant register shift between the stage directions of the pre-1616 quartos and their folio counterparts, it is probable that Jonson purposefully rewrote the $\mathrm{N}$ ebentext for the Folio in the light of his masque-writing (and publishing) experience as he prepared the texts for his upcoming and more reader-oriented compilation.

One of the main differences between the $\mathrm{N}$ ebentext of the masques and the "theatrical language" stage directions of Elizabethan and Jacobean plays is their grammatical mood and tense. The verb of a conventional direction is written in the present tense, and although technically it is in the indicative mood, the sharp bluntness of the grammar makes it sound as if it were an order (indeed, a direction) for the actor to follow. What is more, the directions in Jonson's printed versions of the masques appear in the past tense indicative, as if he were describing a past event instead of pre-establishing the blocking of his plays for theater professionals. ${ }^{9}$ Even though he does

\footnotetext{
${ }^{9}$ One possible explanation for this grammatical shift is that masques often were not written for stage professionals, but for aristocratic amateur performers (Butler 2012a; 2012b). One means of testing this hypothesis would be to contrast practice in court
} 
not go as far as to write them in the past tense, this stylistic or conceptual approach to $\mathrm{N}$ ebentext, which converts the orders of behind-the-scenes professionals into a narrative tone, is one Jonson would carry over from the masques to the folio. The margins of the Workes describe the actions as if they were to happen in some (factual or hypothetical) performance instead of placing explicit demands on the Kopfkino [mental picture] of the reader. It would be, therefore, much more appropriate to talk about "stage descriptions" than "stage directions" when discussing this dimension of the Jonsonian $\mathrm{N}$ ebentext. ${ }^{10}$

With this conversion into a narrative tone comes an inevitable syntactical change in the way of writing $N$ ebentext. This is best illustrated by the alterations of the stage directions of Every $\mathrm{M}$ an $\mathrm{O}$ ut, going from the "verb + subject" structure of the quarto into the "subject + verb" of the folio. One can interpret this change as a

theaters throughout the rest of Europe. To prolong the Anglo-Spanish comparison, let us briefly consider the masque-like play of Querer por solo querer, written by Antonio Hurtado de Mendoza, first performed in 1622 by the Queen's ladies-in-waiting to honor her birthday (and later on by a professional acting company as well) and published in 1629. The 1629 text mixes acotaciones similar to directions in a commercial comedia along with narrative descriptions written in the past tense typical of court plays N ebentext (Shergold 1967, 270-72). We do not know whether the performance script the ladies-in-waiting received was different from that of the professional comediantes, and if that is the case we do not know which of the two the printer of the 1629 version used. However, the discordance in tense use may suggest that the text was partly (or incompletely) modified with the readership of the printed publication in mind. Another text worth analyzing is La gloria de $\mathrm{N}$ iquea by the Conde de Villamediana and also performed in 1622, this time to honor the young King Philip IV's birthday. The amount of both structural and stylistic similarities between this court invención and Jonson's masques may be due, as Gareth A. Davies points out, to Villamediana's father having been the ambassador in London in the early seventeenth century, when the English poet was putting on and publishing his first court spectacles and which he could have seen performed $(1995,59)$. More on this Spanish masque, in addition to Felipe B. Pedraza's edition of the play (Tassis y Peralta 1991), in Chaves Montoya (1991) and Miñana (2000).

${ }^{10}$ To support this alternative nomenclature, I lean on the study of the discordant quarto versions of some early modern plays thought to have been reconstructed from memory, such as the 1597 quarto of Romeo and Juliet. While the dialogue text of this "bad" quarto is imperfect in comparison to the more authoritative 1599 quarto and the subsequent 1623 First Folio texts, the stage directions are longer and more substantial. Indeed, they read as descriptions of a performance, instead of the conventional brief orders of the "theatrical vocabulary" directions, because in a way they were descriptions. For this reason, among others, this quarto is often referred to as "more theatrical" than the "more literary" 1599 text (Belsey 2014, 87-98; Weis 2012, 94-115). 
simple rearrangement of linguistic units in order to make his directions appear to be more reader-friendly. However, Jonson shows his willingness to turn stage directions into more complex linguistic and pseudo-poetic structures, not just marginal annotations. Progressively, especially in the playbooks published after the W orkes, Jonson adds more new elements and nuances rarely seen before in the syntax of sparse playhouse directives, such as coordinated, juxtaposed or subordinated clauses. The 1631 quarto of Bartholomew Fair, which maintains the folio's layout of leaving ample margins for the $\mathrm{N}$ ebentext, is home to some of the most developed syntax in Jonson's stage descriptions, such as the following examples:

Edgworth gets vp to him, and tickles him in the eare with a straw twice to draw his hand out of his pocket. (Jonson 1631, 44)

Cokes falls a scrambling whilest they runne away with his things. (1631, 54)

Here they continue their game of vapours, which is nonsense. Everyman to oppose the last man that spoke: whether it concern'd him, or no. (1631, 59)

As they open the stockes, Waspe puts his shooe on his hand, and slips it in for his leege. $(1631,67)$

Quarlous in the habit of a madman is mistaken by $M^{\text {ts }}$ Pure-craft. (1631, 70)

These five instances of $\mathrm{N}$ ebentext demonstrate the extensive arsenal of Jonson's experiments with syntax for his marginal notes. While they are nowhere close in length and complexity to the descriptions of the printed masques, they no longer belong to the same category as the conventional stage directions, if only visually. These stage descriptions go far beyond simply being longer and more prose-like than the "theatrical language" directions. Jonson adds different content and purpose to his $\mathrm{N}$ ebentext: the result is that it often interprets and/ or judges the actions the characters carry out. In the first example, the stage description explains the reader the purpose behind Edgworth's tickling Nightingale's ear: to make him draw his hand out of his pocket. In the third instance, the reader is informed that the game of vapors is utter nonsense, in case this was not sufficiently clear. The last note explains Dame Purecraft's confusion. 
There is a voice behind the Nebentext, a narrator of sorts, digesting and nuancing the non-verbal codes associated with the theatrical experience for the lay reader. Jonson, the author himself, is present in the experience of reading, making sure we arrive at a safe port after navigating the text. This is what he had hitherto done only in masques, perhaps simply due to conventional expectations. But, this article suggests, Jonson was to discover the aptness for the printed medium of this convention and have his voice increasingly appear in the stage directions of his commercial plays as well, a voice one could expect to find only in the $\mathrm{H}$ aupttext in that period of time. Unluckily for us, for the most part Elizabethan and Jacobean dramatists did not exercise this new option of personalization. Ben Jonson, however, found in them a new outlet for his irrepressible drive to become the first "author" in English literature. He turned the $\mathrm{N}$ ebentext into a sort of $\mathrm{H}$ aupttext by reminding his readership that the margins of the page were still within the limits of his domain. The process, as portrayed here, was slow and called little attention to itself. But it was nonetheless the first step taken in what would become a tradition of highly personalized and authoritative stage directions in the body of western dramatic literature.

\section{References}

Adams, Robert M. 2001. "The Staging of Jonson's Plays and Masques." In Ben Jonson's Plays and Masques, edited by Richard Harp, xi-xvi. New York: W.W. Norton.

Baldick, Chris. 2004 (1990). The 0 xford Concise Dictionary of Literary Terms. Oxford: Oxford University Press.

Barbour, Richard. 1998. "Jonson and the Motives of Print." Criticism 40 (4): 499-528.

Belsey, Catherine. 2014. Romeo and Juliet: Language and Writing. The Arden Shakespeare. London: Bloomsbury.

Butler, Martin. 2012a. "The Court Masque." In The Cambridge Edition of the Works of Ben Jonson, V ol. 1: 1597-1601, edited by David Bevington, Martin Butler, and Ian Donaldson, cxxxii-cxlii. Cambridge: Cambridge University Press.

- - . 2012b. "Masquers and Tilters." In The Cambridge Edition of the Works of Ben Jonson, Vol. 1: 1597-1601, edited by David Bevington, Martin Butler, and Ian Donaldson, cxliii-clxiii. Cambridge: Cambridge University Press. 
Chartier, Roger. 1999. Publishing D rama in Early M odern Europe. London: The British Library.

Chaves Montoya, María Teresa. 1991. La gloria de N iquea: una invención en la corte de Felipe IV . A ranjuez: Doce Calles.

Cueva, Juan de la. 1582. Obras de Ivan de la Cveva. Sevilla: Francisco Rodríguez.

_- _ 1588. Primera parte de las comedias y tragedias de Ioan de la Cveva. Sevilla: Juan de León.

Davies, Gareth A. 1995. “La Fiesta de Aranjuez: 1622." Grama y Cal: Revista Insular de Filología 1: 53-71.

Dessen, Alan C. 1995. Recovering Shakespeare's Theatrical Vocabulary. Cambridge: Cambridge University Press.

- - - , and Leslie Thomson. 2001. A D ictionary of Stage D irections in English D rama 1580-1642. Cambridge: CambridgeUniversity Press.

Dixon, Víctor. 1989. “Manuel Vallejo. Un actor se prepara: un comediante del Siglo de Oro ante un texto (El castigo sin venganza)." In A ctor y técnica de representación del teatro clásico español, edited by José María Díez Borque, 55-74. London: Tamesis.

Dutton, Richard. 1983. Ben Jonson: To the First Folio. Cambridge: Cambridge University Press.

Granja, Agustín de la. 1989. "El actor y la elocuencia de lo espectacular." In Actor y técnica de representación del teatro clásico español, edited by José María Díez Borque, 99-120. London: Tamesis.

Greer, Margaret R. 2009. “Early Modern Spanish Theatrical Transmission, Memory, and a Claramonte Play." In H ispanic Studies in H onor of R obert L. Fiore, edited by Chad M. Gasta and Julia Domínguez, 261-80. Newark, DE: Juan de la Cuesta.

- _ . 2012. "Authority and Theatrical Community: Early Modern Spanish Theater Manuscripts." Renaissance D rama, N ew Series 40: 100-12.

Ichikawa, Mariko. 2013. The Shakespearean Stage Space. Cambridge: Cambridge University Press.

Ingarden, Roman. 1972 (1931). D as literarische Kunstwerk. M it einem Anhang von der Funktionen der Sprache in Theaterschauspiel. Tübingen: Max Niemeyer.

Ioppolo, Grace. 2006. Dramatists and their Manuscripts in the Age of Shakespeare, Jonson, M iddleton and H eywood: Authorship, A uthority and the Playhouse. London: Routledge.

_- - 2007. "Hengist, King of Kent; or, The Mayor of Queenborough." In Thomas Middleton and Early Modern Textual Culture: A Companion to the 
Collected Works, edited by Gary Taylor and John Lavagnino, 1029-61. Oxford: Clarendon Press.

Johnson, Nora. 2003. The Actor as Playwright in Early Modern Drama. Cambridge: Cambridge University Press.

Jonson, Ben. 1600. The Comicall Satyre of Every M an O vt of his H vmor. London:

William Holme.

_-_. 1602. Poetaster or The A rraignment. London: M.L.

-_- 1607. V ol pone or The Foxe. London: Thomas Thorpe.

- - - 1608? The Characters of Two R oyall M asques. The 0 ne of Blacknesse, The Other of Beavtie. London: Thomas Thorpe.

_-_. 1616. The W orkes of Beniamin Jonson. London: Richard Meighen.

Jowett, John. 2007. Shakespeare and Text. Edited by Peter Holland and Stanley Wells, Oxford Shakespeare Topics series. Oxford: Oxford University Press.

Kidnie, Margaret Jane. 2000. "Text, Performance, and the Editors: Staging Shakespeare's Drama." Shakespeare Q uarterly 51 (4): 456-73.

Loewenstein, Joseph. 2002. The Author's Due: Printing and the Prehistory of Copyright. Chicago: University of Chicago Press.

McJannet, Linda. 1999. The V oice of Elizabethan Stage D irections: The Evolution of a Theatrical Code. London: A ssociated University Presses.

McKerrow, R. B. 1931. "The Elizabethan Printer and Dramatic Manuscripts." The Library IV 12 (3): 253-75.

Miñana, Rogelio. 2000. "Representar lo irrepresentable: La gloria de N iquea de Villamediana." In EI texto puesto en escena: estudios sobre la comedia del Siglo de Oro. En honor a Everett W. Hesse, edited by Bárbara Mujica and Anita K. Stoll, 113-20. London: Tamesis.

Parker, Brian, and David Bevington. 1999 (1983). "Introduction." In V olpone, by Ben Jonson, 1-29. Manchester: Manchester University Press.

Pfister, Manfred. 1988. The Theory and Analysis of Drama. Cambridge: Cambridge University Press.

Profeti, Maria Grazia. 1999. “Escritura, compañías, destinatarios: un teatro de la ambigüedad." In Cervantes y la puesta en escena de la sociedad de su tiempo, edited by Catherine Poupeney Hart, Alfredo Hermenegildo, and César Oliva, 55-75. Murcia: Universidad de Murcia.

Rijsberman, Marijke. 1987. "Forms of Ceremony in Ben Jonson's Masques." In Ben Jonson, edited by Harold Bloom, 223-38. New York: Chelsea House.

Rose, Mark. 1993. A uthors and O wners: The Invention of Copyright. Cambridge, MA: Harvard University Press. 
Shergold, N.D. 1967. A H istory of the Spanish Stage: From M edieval Times until the End of the Seventeenth Century. Oxford: Clarendon Press.

Stern, Tiffany. 2009. Documents of Performance in Early Modern England. Cambridge: Cambridge University Press.

Syme, Holger Schott. 2008. "Unediting the Margin: Jonson, Marston, and the Theatrical Page." English Literary Renaissance 38 (1): 142-71.

Tassis y Peralta, Juan de [Conde de Villamediana]. 1991. La Gloria de N iquea: una invención en la Corte de Felipe IV . A ranjuez: Doce Calles.

Vega, Félix Lope de. 1634. El castigo sin venganza, tragedia de frey Lope Felix de Vega Carpio. Madrid: Pedro Lacavalleria.

- - - 1635. El castigo sin venganza. In Veinte y vna parte verdadera de las comedias del fenix de España Frei Lope Felix de Vega Carpio, 91-113v. Madrid: Diego Logroño.

Weis, René. 2012. "Introduction." In Romeo and Juliet, by William Shakespeare, 1-116. London: Bloomsbury.

Werstine, Paul. 2012. Early M odern Playhouse M anuscripts and the Editing of Shakespeare. Cambridge: Cambridge University Press.

How to cite this article:

Amelang, David J. "From directions to descriptions: Reading the theatrical

N ebentext in Ben Jonson's W orkes as an authorial outlet." SEDERI 27 (2017): 7-26.

A uthor's contact: david.amelang@fu-berlin.de

Postal address: Institut für Englische Philologie - Habelschwerdter Allee 45 - 14195

Berlin - Germany

Submission: 02/ 08/ 2016

A cceptance: 07/ 10/ 2016 


\title{
Shakespeare in La M ancha: Performing Shakespeare at the AImagro Corral
}

\author{
Isabel Guerrero \\ U niversidad de M urcia, Spain
}

\begin{abstract}
Shakespeare is one of the most often performed playwrights at the Festival de Teatro Clásico de Almagro [The Almagro Festival of Classical Theater], an event initially created to celebrate Golden Age drama in which, nowadays, Shakespearean productions often outnumber those by individual national authors. Throughout the history of the festival, several Shakespearean productions have been staged in the Corral de Comedias, an original seventeenth-century venue that reactivates the use of space encoded in the playtext due to its similarities with Renaissance playhouses. This article has a double purpose: first, to examine the abundance of Shakespeare in A Imagro as a phenomenon that finds its explanation in factors ranging from Shakespeare's popularity to the role of modern translation and, second, to focus on how Shakespearean productions at the Corral de Comedias have negotiated new meanings of Shakespeare in performance, generating an interplay between Renaissance and Golden Age venues in contemporary performance.
\end{abstract}

KEYWORDS: William Shakespeare; contemporary performance; Golden Age; theater architecture; theater festivals.

\section{Shakespeare en la M ancha: la representación de Shakespeare en el Corral de A Imagro}

RESUMEN

Shakespeare es uno de los autores representados con mayor frecuencia en el Festival de Teatro Clásico de Almagro. Este encuentro estuvo inicialmente dedicado a la preservación del teatro del Siglo de Oro español. No obstante, las producciones shakesperianas superan hoy día a las de muchos autores nacionales. A lo largo de su historia, el festival ha acogido diversas producciones de Shakespeare en el Corral de Comedias, un edificio teatral del siglo XVII en el

\section{Shakespeare em La M ancha: A representação de Shakespeare no Corral de A Imagro* \\ RESUMO}

Shakespeare é um dos autores mais frequentemente representados no Festival de Teatro Clásico de A Imagro, um encontro inicialmente criado para celebrar o drama do Século de Ouro espanhol, mas no qual as produções de Shakespeare superam em número as de muitos autores nacionais individuais. Ao longo da história do festival, várias produções de Shakespeare foram encenadas no Corral de Comedias, um edifício teatral do século XVII, o qual, devido à sua seme-

\footnotetext{
*Translation into Portuguese by Miguel Ramalhete.
} 
que, debido a su similitud con los teatros de la Inglaterra renacentista, se reactivan los usos del espacio codificados en el texto. Este artículo tiene dos propósitos fundamentales, por un lado, examina las causas que han Ilevado a Shakespeare a convertirse en el autor más representado en Almagro, un hecho que encuentra su explicación en factores tan diversos como la popularidad del dramaturgo inglés o el papel de la traducción al español. Por otro lado, el artículo estudia cómo las producciones de Shakespeare en el Corral de Comedias generan nuevos significados en la puesta en escena de las obras, creando una interacción entre los teatros del Siglo de Oro y los renacentistas ingleses desde la representación contemporánea.

PALABRAS CLAVE: William Shakespeare; representación contemporánea; Siglo de Oro; arquitectura teatral; festivales de teatro.
Ihança com os teatros da Inglaterra renascentista, reativa os usos do espaço codificados no texto dramático. Este artigo cumpre dois propósitos fundamentais: em primeiro lugar, examinar a abundância de Shakespeare em Almagro, enquanto fenómeno que encontra a sua explicação em fatores que vão desde a popularidade de Shakespeare até ao papel da tradução contemporânea; em segundo lugar, focar-se no modo como as produções de Shakespeare no Corral de Comedias têm vindo a negociar novos sentidos para a representação de Shakespeare, gerando uma interação entre os teatros renascentista inglês e do Século de Ouro através da representação contemporânea.

PALAVRAS-CHAVE: William Shakespeare; representação contemporânea; Século de Ouro; arquitetura teatral; festivais de teatro.

SHAKESPEARE.- In a village of England, the name of which I have no desire to call to mind, there lived not long since one of those writers that write for the theater, quick of wit, sharp of pen and rich in fame. The age of this writer of ours was bordering on fifty; he was of a hardy habit, spare, gauntfeatured, a very early riser and a great sportsman. They will have it his name was William, or Will, but this is of little importance to our tale; it will be enough not to stray a hair's breadth from the truth in the telling of it.

M iguel W ill, José Carlos Somoza

William Shakespeare literally made his entrance on the stage of the Festival de Teatro Clásico de Almagro [The Almagro Festival of Classical Theater] on the evening of 17 July 1997. The playwright, transformed into the protagonist of the play M iguel Will, written by José Carlos Somoza, delivered the lines above at the beginning of the play. Nevertheless, his words were not recognized as Shakespeare's, as they paraphrased the popular opening of D on Q uixote. M iguel Will tells the story of the staging of Cardenio, the lost play written by Shakespeare in collaboration with John Fletcher inspired by an episode in Cervantes' novel, as performed by the King's Men and 
casting Shakespeare himself in the title role. The play was the winner of the First Cervantes Theater Prize, organized on the occasion of the four $450^{\text {th }}$ anniversary of the birth of Cervantes. The award included the staging by the Compañía Nacional de Teatro Clásico, Spain's national company, plus its premiere at the Almagro Festival. The plays eligible for the award had to capture Cervantes' essence. It is through Shakespeare's imaginary tribute to Cervantes with the staging of Cardenio that this essence is captured in M iguel Will.

It is paradoxical that the winner of the award or, what is the same, the play chosen to celebrate Cervantes' $450^{\text {th }}$ birth anniversary, resorts to Shakespeare to remember the Spanish writer, who wanted to become a playwright but whose dramatic production-much more limited than that of his contemporaries Lope de Vega or Cal derón-was never successful during his lifetime. ${ }^{1}$ This paradox is further increased if the fact that the play premiered at the Almagro Festival performed by Spain's national company-two institutions devoted to the promotion and preservation of Golden Age theateris taken into consideration.

Had the play been staged in the Corral de Comedias, the seventeenth-century venue of the Almagro Festival, it would have been too much for the Cervantine celebration: Shakespeare would have not only displaced the attention that was due to Cervantes in that year, but he would have even occupied a physical space similar to the venues in which Cervantes had desired to see his plays performed with more frequency. ${ }^{2}$ However, M iguel Will did not go that far. The performance took place in the proscenium-arch Teatro Municipal, a much more contemporary venue than the Corral. Although Shakespeare did not occupy the original space of Spanish Golden Age drama, his works did receive more attention than those by Cervantes in that festival season. The only productions programmed to mark Cervantes' anniversary were M iguel Will, with Shakespeare as the main protagonist, and a performance of his Entremeses. In contrast, two other Shakespearean productions were

\footnotetext{
${ }^{1}$ Cervantes acknowledges his passion for the theater in the prologue to his Comedias $y$ Entremeses, as well as in several references in D on Q uixote and other prose works. The fact that he decided to publish eight of his plays is considered a sign of his failure to have them performed (Sánchez 1992).

${ }^{2}$ Due to the date of construction of the Corral (1628), it is unlikely that Cervantes' dramatic pieces had been staged in this venue.
} 
staged (The Tempest, dir. Calixto Bieito; M uch A do about N othing, dir. Juan Carlos Corazza).

The celebration of Golden Age Spanish theater and the Corral have been two of the pillars of the Almagro Festival since its inception in 1978. The festival, held in the Castilian town of Almagro, intended to revive Spanish Golden Age classics, which had been used to support the ideology of Franco's regime in the 1940s and had experienced a dramatic decrease on the Spanish stages from the 1960s to the 1980s (Peláez Martín 1997, 25; García Lorenzo and Muñoz Carabantes 1997, 64). It is only in the 1980s, once the festival widened its scope to include international artists and authors, when the first Shakespearean productions were staged in Almagro. ${ }^{3}$ The festival celebrates sixteenth- and seventeenth-century theater, with special attention to Spanish Golden Age classics. Nevertheless, Shakespearean productions often outnumber those by individual national authors, with Shakespeare stealing the scene from Golden Age authors. Shakespeare's intrusion in the celebration of Spanish classical theater is enhanced when his plays are performed in the Corral de Comedias. This article has a double purpose, first, to examine the abundance of Shakespeare in Almagro as a phenomenon that finds its explanation in factors ranging from Shakespeare's popularity to the role of modern translation and, second, to focus on how Shakespearean productions at the Corral de Comedias have negotiated new meanings of Shakespeare in performance, generating an interplay between Renaissance and Golden Age theater.

\footnotetext{
${ }^{3}$ The first Shakespearean productions, staged in 1984, were Pericles, dir. Declan Donnellan; La Tempestad, dir. Edgar Saba; A M idsummer Night's D ream, dir. Jaume Bordera. The inclusion of Pericles, by the international company Cheek by Jowl, and A $M$ idsummer Night's D ream, performed in Catalan, illustrate the evolution of Spanish theater under the new democratic government, with the emergence of the "teatro de las nacionalidades" [theater of nationalities]-theater in the regional languages of Spain often used to support nationalist causes-and the increasing numbers of foreign companies on the Spanish stages (Ruiz Ramón 1988, 103-13; Berenguer and Pérez 1998, 36).
} 


\section{Shakespeare in the Company of G olden A ge A uthors}

The steady rise of Shakespearean productions throughout the history of the Almagro Festival has led to a tension between the original purpose of the festival (preserving Golden Age drama), and the profusion of Shakespeare's works. The analysis of the festival programs, gathered in the Museo Nacional del Teatro in Almagro, shows that the festival seasons in the 1980s did not include more than one or two, if any, of Shakespeare's plays on average; however, the beginning of the twenty-first century has witnessed a dramatic increase. $^{4}$ In 2015, the Almagro Festival reached a historical maximum of Shakespeare's plays, with nine productions in the program. In contrast, the three most popular Spanish playwrights of the period only amounted to eleven productions: five by Lope de Vega and Calderón respectively, and only one by Tirso de Molina. This domination of Shakespeare on the Almagro stages is not unique, but reproduces the general theatrical landscape in Spain. Keith Gregor has noted the Spanish addiction to Shakespeare at the beginning of the twenty-first century, pointing out that Shakespearean productions do not only outnumber the works by individual Golden Age playwrights, but even sometimes "the combined dramatic efforts of all of Spain's classical authors" (2010, 1). The production of more Shakespeare than national classical authors in the country as a whole can go somehow unnoticed, but the concentration of theatrical events at the Almagro Festivaltaking place in a single city in the span of a month-brings such contrast to the fore. It is precisely due to the large number of Shakespeare's plays, often outnumbering the plays by individual Spanish playwrights, that the study of Shakespeare in Almagro is relevant.

Nevertheless, the presence of more plays by Shakespeare than by individual national authors has not been a real threat to the celebration of national theater in Almagro, as the total number of Golden Age productions has always been greater. In 2015, Shakespearean productions occupied $22.5 \%$ of the program, those by Lope de Vega, Calderón and Tirso put together reached $27.5 \%$, and the remaining $50 \%$ were by other Spanish and foreign classical

\footnotetext{
${ }^{4}$ The increasing number of Shakespearean productions in AImagro al ready caught the attention of José Manuel González (1999), whose chapter "Shakespeare in Almagro" offers an overview of the Shakespearean productions in the festival in the 1990s.
} 
authors. ${ }^{5}$ However, in a national as well as international market in which Shakespeare is, by far, the playwright most often performed, the organizers of the Almagro Festival need to design each season carefully in order to prevent Shakespearean productions from completely taking over the program.

Apart from paralleling a national trend, the most obvious explanation for Shakespeare's omnipresence in Almagro is that he stands as the most popular playwright of the period to which the festival is devoted. ${ }^{6}$ As a thematic festival focused on a specific moment of theater history and featuring only works from the sixteenth and seventeenth centuries or related somehow to this period, the festival foregrounds the link between the productions presented and this historical past, a connection that, most of the time, comes via the playwright. This means that Shakespearean works are eligible to be presented at the festival precisely because they have been written by Shakespeare. In this case, the historical time when they were created and Shakespeare's canonical status are the two main explanations for the abundance of Shakespeare's plays at the festival. The historical requirement shapes the meaning of the Almagro Festival as an event and affects the reading of the productions. The inclusion of Shakespearean productions in the festival marks them as representatives of a historical period, whose performance in the festival is intended to show that these works can still speak to contemporary audiences, no matter how long ago they were written. Shakespeare's canonicity and the commercial success of his works on the Spanish stage also explain why his works are performed in Almagro much more often than those by other English playwrights of the same period, as Marlowe or Fletcher.

Shakespeare's works have been performed in a wide range of styles at the festival, pointing out their relevance in twenty-firstcentury theater: from productions recontextualizing the action in our days (e.g. Coriolanus, dir. Àlex Rigola, 2012; The M erry Wives, dir. Andrés Lima, 2015), to playful parodies and pastiche adaptations (e.g. Shakespeare para ignorantes, 2013), or productions in a more

\footnotetext{
${ }^{5}$ Data obtained using the information available in the 2015 festival program.

${ }^{6}$ Jonathan Bate (1997) argues that part of Shakespeare's popularity is due to the political victory of England over Spain and that had Spain's power not declined after the seventeenth century, Lope's fate would have been certainly different and he would "have triumphed over Shakespeare" (338).
} 
canonical style (e.g. The M erry Wives of Windsor, dir. Gustavo Tambascio, 2001; $\mathrm{H}$ amlet, dir. Alfonso Zurro, 2015). This variety of approaches to Shakespeare in performance does not find an equivalent in Golden Age productions. Even if they are sometimes adapted and updated to be contextualized in our days, Golden Age plays do not undergo such generalized processes of adaptation as has been the case with Shakespeare's plays. ${ }^{7}$ A quick overview of the productions in A Imagro, as well as of those in the country in general, reveals that whereas the tendency in Shakespearean productions is to perform the plays in contemporary attire, a large number of Golden Age works are in period costume to evoke seventeenthcentury theater. This apparently insignificant detail gives an idea of to what extent the plays of the Golden Age are still made to represent the national historical past.

The connotations that the plays from the Golden Age carry with them, as well as some of their characteristics such as the topics or language, or even their performance tradition, might also explain why they are not performed in such varied styles as in the case of Shakespeare. Golden Age works are still regarded as Spanish sacred classics, which deserve respect and require some degree of historical accuracy, as the frequent performance in period costume indicates. Whereas some of the topics that the plays address, such as love or vengeance, can have a universal and contemporary appeal, others have lost their currency in contemporary society, like those dealing with honor or religion (Gregor 2005, 240-41). The ideological appropriations of Spanish Classics in the early years of Franco's dictatorship, together with their almost complete absence from Spanish stages from the 1960s until the 1980s, explains why the experimentation with and adaptation of Golden Age plays have been much more limited than in the case of Shakespeare's works, which have been continuously reinvented all through the twentieth century. All this hinders the adaptability of certain plays of the Golden Age canon for contemporary theater.

\footnotetext{
${ }^{7}$ Gregor $(2010,2)$ refers to the plurality of approaches to Shakespeare as one of the main characteristics of Shakespearean performance in Spain since the 1990s, and he explicitly mentions the AImagro Festival as a paramount example of this variety.
} 
Shakespeare's works in modern translation are, in general, linguistically more accessible to Spanish audiences than the works of Golden Age theater. Well-trained companies like the Compañía Nacional de Teatro Clásico recite classical Spanish verse in its sixteenth- and seventeenth-century language with the purpose to make it as accessible as possible. Nevertheless, audiences not familiar with Golden Age theater usually need to get used to the rhymed verse before being able to fully grasp the meaning of the dialogues. Such difficulty does not appear in Shakespeare's performances in modern translation; as Rafael Portillo and Manuel J. Gómez Lara point out, "since the vast majority of Spaniards cannot understand his original English, modern translations, particularly those written for the stage, make Shakespeare sound quite 'contemporary' to the ears of the audience" (1994, 219). Thus, Spanish festival-goers in Almagro might feel closer to Shakespeare's language in translation than to Lope's Golden Age Spanish.

\section{Performing Shakespeare in the A Imagro Corral}

At the Almagro Festival, Shakespeare has not only occupied a symbolic space initially devoted to the preservation of Golden Age drama, but has also entered a physical space from that time, the Corral de Comedias. ${ }^{8}$ The Corral was built in 1628 and was used to stage plays during the Golden Age. In the eighteenth century, with the prohibition of the corrales, the building was transformed into a tavern and was not rediscovered until 1950 (García de León Álvarez 2000). As several critics have pointed out, theater architecture serves not only to contain meaning, but it is also an active element in the process of meaning making (Carlson 1989, Mcauley 2000); in the words of Juliet Rufford, "theatre is a temporal art but it is also one that signifies spatially" $(2015,8)$. Part of the spatial meaning of Shakespearean productions at the Corral is determined by the adaptation of the performances to the spatial configuration of the venue, as well as by their use of the resources available in it (i.e.

\footnotetext{
${ }^{8}$ The opposite, the performance of Golden Age works in an Elizabethan venue, at least in the closet example existing nowadays, the reconstruction of Shakespeare's Globe, took place with the performance of Lope de Vega's El castigo sin venganza [Punishment without Revenge] by Lope de Vega by the company Rakatá in September 2015.
} 
balconies, working doors,...). The historical connotations of a theater space also intervene in the spatial meaning of performance. Because of its historical origin, the Corral can be described, to borrow Marvin Carlson's words, as a "haunted house" (2001, 131), a space that activates the connection between contemporary performance and the theatrical past of the Spanish Golden Age.

The Spanish corrales and the Elizabethan public playhouses, two types of sixteenth-century theater architecture, share several features (Hildy 2004; Allen 1990). Franklin J. Hildy acknowledges the importance of the Corral de Comedias in Almagro for the study of Elizabethan amphitheaters because it "remains the only existing theatrical space in Europe with any resemblance to the open-air playhouses of Shakespeare's day" (2004, 101). This resemblance starts in the spatial configuration of the corrales and the Elizabethan amphitheaters. In both types of venues, audiences were distributed in three sides around the stage on different levels, from the lower level-the yard in Elizabethan playhouses and the patio, its equivalent in the corrales - to the galleries. ${ }^{9}$ As in Elizabethan amphitheaters, the corrales tended to be open-air constructions. Their location in relation to the city was, nevertheless, different, with the corrales situated in the city center and the Elizabethan venues outside the city walls. The placement of the corrales inside the city explains their square or rectangular shape as they had their origin in the inner courtyards of buildings that were used for the performance of touring companies. This ad hoc space derived in purpose-built theaters, as is the case of the Corral de Comedias in Almagro. In contrast, Elizabethan public theaters usually had a circular or octagonal shape, but their origin can be also traced back to temporary arrangements in the yards of inns, as it is known to have been the case of the Boar's Head and the Red Bull (Gurr 2009, 147). ${ }^{10}$ In the corrales, the front part of the patio was filled with benches and the back was occupied by standing men (known as mosqueteros),

\footnotetext{
${ }^{9}$ For a detailed description of the corrales and Golden Age theater practices see Ruano de la Haza (2000); Ruano de la Haza and Allen (1994). For an analysis of the corrales in English see Thacker (2007). A general analysis on Elizabethan venues and theater practices at the time is provided in Gurr (2009). Recent studies on performance at the Shakespeare's Globe have also shed some light on the practices of Renaissance theater (Karim-Cooper and Stern 2013; Carson and Karim-Cooper 2008).

${ }^{10}$ Both the Boar's Head and the Red Bull were officially transformed into play houses after the ban on staging plays at inns.
} 
reversing the pattern of Elizabethan theaters in which standing audiences were at the front and seating spectators in the lower gallery at the back.

Nowadays, the Corral in Almagro preserves the overall original disposition of audiences in the patio and the galleries, although there are no longer spectators on the sides of the stage or standing, the benches have been substituted by chairs and there is artificial lighting. A fter a recent restoration in 2004, Felipe Delgado Laguna and Isidro G. Hidalgo Herrero, the architect and archaeologist in charge of the project, stated that the Corral has been "able to meet the technical requirements and the architectural features to become a modern twenty-first-century building preserving intact its personality and its popular architecture" $(2006,155) .{ }^{11}$ Technological innovations and seventeenth-century elements coexist in the restored Corral. The venue has three bal conies in the upstage gallery (similar to the Lord's room in Elizabethan amphitheaters), and two working doors at stage level plus two exits on the sides, elements that many productions integrate into the performance.

The similarities between Elizabethan and Golden Age theaters, together with the resources available in the sixteenth and seventeenth centuries, result in similar performing practices, such as the integration of the architecture into the action or the constructedness of theater practice. Andrew Gurr observes that in Elizabethan theater practices the "awareness of the illusion as illusion was [...] much closer to the surface all the time" $(2009,180)$, a statement that is also true for Golden A ge theater. Scenes requiring an upper level were performed in the balconies in both traditions and the central door at stage level provided space for the apariencias in Spain and discovery scenes in England. ${ }^{12}$ The two traditions also created meaning with similar resources. For instance, a chair and a desk on the English and Spanish sixteenth- and seventeenth-century stages would have functioned as referential stage properties (Ubbersfeld 1999, 123) to indicate that a scene was placed indoors;

\footnotetext{
11 “Ha sido capaz de recoger por sí mismo las condiciones técnicas y arquitectónicas para ser un edificio moderno del siglo XXI manteniendo su personalidad, el lenguaje de su arquitectura popular." My translation.

${ }^{12}$ The apariencias were scenes generally shown behind the central door at stage level that pursued to make a visual impact on their audiences (Ruano de la Haza 2000, 226).
} 
likewise, branches and plants suggested outdoor locations and the use of torches and candles announced night scenes.

Shakespearean and Golden Age works might have been written with the venues where they were going to be performed in mind, integrating into the action specific characteristics of these spaces. There is no way of determining whether this was the case, but there is conclusive evidence for the performance of Shakespeare's works in a variety of locations (open-air playhouses, small indoor theaters such as Blackfriars, the Inns of Court or a palace at court). At the same time, there are indications in the plays that the specific characteristics of these spaces were put to good use in the dramatic action. This means that, given the similarities between Elizabethan amphitheaters and the Spanish corrales, Shakespearean productions performed at the Corral de Comedias in Almagro have the possibility to reactivate the use of space encoded in the playtext and to give rise to new spatial meanings in a venue that is, at the same time, historically accurate (built in the seventeenth century), but geographically displaced (in Spain instead of England), while the performance takes place in present-day Spain. The first production to materialize such interplay took place in 1984, when Cheek by Jowl was invited to perform Pericles at the festival. ${ }^{13}$ Since then, twentyone different Shakespearean productions have been staged there as part of the Almagro Festival, and each has interacted with this historical building in diverse ways. The reasons for such a reduced number of Shakespearean productions in this space, twenty-one in contrast to the 132 productions staged in the festival until 2016, are simple: the reduced dimensions of the stage (the stage in Almagro is quite shallow, around 8 meters wide by 5 meters deep), and some of the technical restrictions of the venue make it difficult to accommodate big-scale productions with large casts, as those in most of the Shakespearean productions at the festival, which are more easily staged in other venues. The challenge faced by Shakespearean productions in the Corral is not how to recreate original theater practice from the Golden Age or the Renaissance, but

\footnotetext{
${ }^{13}$ There are no indications of Shakespearean productions in the Corral before the one in 1984. From its restoration and reopening in 1954 until the inauguration of the festival, the Corral was mainly used to stage Golden Age plays, including those for the TV series Teatro de Siempre, and for local festivities.
} 
how to accommodate present-day productions-devised to be staged in a more contemporary venue-in this historical space.

Cheek by Jowl's Pericles was not only the first example of Shakespeare in this space, but also the first visit of the company to both the festival and Spain. The company has periodically returned to the festival since then, presenting up to five Shakespearean productions and becoming the international company that has most often performed Shakespeare in Almagro. ${ }^{14}$ Pericles proved a good example of the theater practice of the company, a style whose core axioms have been summarized by Paul Prescott as follows:

[...] that the art of the theatre is above all the art of the actor; that the director's primary job is to nurture the health of the ensemble; that the story and the text are not the same thing and that in the case of a clash, the former must prevail; that every single line must be new-minted; that the emotionally unblocked actor needs less physical blocking; that the scenery and props should never obtrude between the actor and the audience; that rehearsals and the process of discovery continue until the final performance; that there must al ways be something at stake. $(2008,70)$

All these were present in Pericles, performed by seven actors who doubled and tripled characters. Far from being an obstruction between actor and audience or, even more, between actor and performance space, the setting and props perfectly adapted to the Corral. What was at stake at this specific performance was the resonance of the play when staged in this particular venue. The set featured a wooden door in the center of the stage and two boxes that constantly varied their function to recreate different moments in the play. They were used, for instance, to represent the ship when Pericles leaves Pentapolis, and transformed later into the coffin in which Thaisa is thrown overboard being left for dead. A side from its imaginative functionality, the set did not try to impose itself over the elements of the venue, but left the back wall of the stage perfectly

\footnotetext{
${ }^{14}$ A part from Pericles (1984), the productions by Cheek by Jowl at the Almagro Festival include: M easure for M easure (1994), O thello (2004), Twelfth Night (2008) and Troilus and Cressida (2008). M easure for $\mathrm{M}$ easure, $\mathrm{O}$ thello and Twelfth $\mathrm{N}$ ight took place in the Teatro Municipal, while Pericles and Troilus and Cressida were staged in the Corral. The relationship between the company and the festival has been an intense one, with Declan Donnellan and Nick Ormerod (the stage designer) receiving the Corral de Comedias award in 2008.
} 
visible-a white wall with some wood pillars, plus the doors and balconies.

The set, together with the costumes of the actors, who were in sailor-like attire, did not try to locate the action in a precise historical time, but rather indicated a timeless space appropriate to evoke the multiple voyages in Pericles. Instances of physical theater served to present on stage events that would be otherwise difficult to conjure up. This was the case of the storm during which Thaisa gives birth to Marina, created thanks to the movements of the actors. The importance of physical theater in this production can be interpreted as an expansion of the dumb shows in the play, as both show (in images) rather than tell (with words). Instead of restricting the narration with images only to transitional scenes, the physical actions of the actors remained essential all through the production. This led to an emphasis on the visual, enhancing the accessibility of the production, performed in English for a mainly Spanish audience. Gower's lines were shared by all the actors, who took turns to deliver them addressing the audience directly. The direct address was favored by the proximity of the audience to the stage in the Corral, in which the first row of spectators is barely two meters away from the scene. The simple set, the use of physical theater and the closeness of the auditorium and the stage in the Corral highlighted the constructedness of theater, recalling some of the mechanisms of Elizabethan and Spanish Golden Age theater. As in those times, Cheek by Jowl challenged their audiences with a production in which they had to engage with the imaginative solutions on stage.

Other Shakespearean productions in the Corral have integrated the architecture of the venue into their mise en scène more directly, as was the case of The M erry W ives of W indsor (dir. Gustavo Tambascio, 2001). The production relied on the architectural features of the space (i.e. the working doors on stage, the balconies and the side entrances) to locate the action and create diverse stage configurations involving the stage and the balconies. The opening scene already foreshadowed the intention to occupy all the performing spaces available at the Corral. A musician, playing the harpsichord in one of the side galleries over the stage, presented the play while the actors appeared in different spaces of the theater (at the doors, balconies, etc.) as he announced: 
The Merry Wives of Windsor by William Shakespeare A very pleasant and excellent comedy of John Falstaff and the merry wives, mixed with different genres by Sir Hugh, the Danish gentleman, the judge Shallow, and his nephew Slender, with the boastful veteran Pistol and Nym, as it has been acted at various times by members of the honourable Lord Chamberlain on the occasion of the feast of The Most N oble Order of the Garter for Her Majesty Elizabeth I. ${ }^{15}$

The opening lines reveal the aura of authenticity that the production as a whole attempted to evoke, presenting the production as if it was the one performed by the Lord Chamberlain's Men and premiered for Elizabeth I. The introduction of some features of original practice in the mise en scène contributed to this evocation of authenticity, such as the use of period costumes or on-stage music-there were two other musicians playing guitar on stage apart from the one on the harpsichord and the piece they played several times was "Greensleeves."

The architecture of the Corral was all the scenography that the production needed. The doors at stage level were, in general, consistently used for the entrance or exit to a room when the action was located indoors, and as the entrance to a house when it took place outside. ${ }^{16}$ The entrance of a group of characters through one of the sides and their immediate exit through the other indicated that they were walking on their way to somewhere. During the first half of the performance, the changes of scene were announced by a character onstage, who proclaimed both the location and the scene number. Most of the announcements were made from the central balcony, and were on occasions accompanied by a board indicating

\footnotetext{
15 "Las alegres comadres de Windsor de William Shakespeare, una muy agradable y excelente comedia de Sir John Falstaff y las alegres comadres, entremezclada con géneros variados de Sir Hugh, el caballero danés, el juez Shallow y su sobrino Slender, con la jactanciosa vanidad del veterano pistola y el Cabo Nym, tal y como ha sido actuada en diversos momentos por los miembros del honorable Lord Chamberlain en ocasión de la festividad de la orden de la jarretera ante su majestad Isabel I." Las al egres comadres de Windsor, dir. Gustavo Tambascio, 2001. Quoted from the recording by the Centro de Documentación Teatral at the A Imagro Festival 2001. My translation.

${ }^{16}$ Mariko Ichikawa $(2002,85)$ has discussed the use of stage doors in Elizabethan venues, suggesting that doors represented the entrance/ exit to a particular place at specific moments during the performance.
} 
the scene location. ${ }^{17}$ For the first scene at the inn, for instance, one of the secondary characters appeared on the balcony carrying a sign with the words "Garter Inn," which resembled the actual board that could have been found on the facade of an inn.

In addition to the announcements, the boards and the references to locale also present in the text, the performance employed other elements to situate a scene indoors or outdoors. One of them was bringing furniture or other props into the stage. Thanks to this technique, also characteristic of Elizabethan and Golden Age theater, a chair, some stools and the buck-basket (where Falstaff hides the first time he needs to escape from the house without being seen by Mr. Ford) were enough to transform the stage from a street setting into an indoor room. The last scene was situated in Windsor Park just by adding some branches to the costumes of the actors. In sixteenth- and seventeenth-century theater, the performance of the plays during day-time enhanced the interaction between the stage and the auditorium, as public and actors shared the samelight. Here, however, the introduction of artificial lighting clearly separated actors and spectators, with stage lighting to indicate changes in locale and the time of the action. Night scenes, for instance, used low intensity lights in blue shade for indoor scenes and in amber for indoor locations, perhaps in an attempt to recreate the color of candle light of past times, when such props were made to represent night scenes.

In Golden Age theater, the doors, usually covered by hangings, were often used to hide characters or help them to exit without being seen. A typical plot of the comedia involves a lover visiting his lady and having to escape from the house because of the unexpected arrival of her father or brothers, as is the case of Casa con dos puertas mala es de guardar [A House with Two Doors Is Difficult to Guard], by Calderón de la Barca. In this play, the two doors of the house allow the lover (known as galán) to visit his lady and exit without being caught. Likewise, hiding and escaping are central to The M erry Wives of Windsor, where Mistress Page and Mistress Ford fool both Falstaff and Mr. Ford. In Falstaff's two visits to Mistress Ford in this production, Mistress Page hides behind the central door to overhear

${ }^{17}$ According to Gurr (2009, 180), some performances of Court plays in private playhouses used boards to indicate the location. Their introduction here could be interpreted as an echo of this practice. 
the conversation between her friend and Falstaff, and Falstaff hides behind the other door when Mistress Page enters to bring news about Mr. Ford. In his second visit, Falstaff is taken upstairs by Mistress Page to be dressed as the maid's aunt of Brentford. The first glimpse that the audience catches of him in disguise takes place in one of the upper balconies, anticipating the subsequent comedy when he reaches the stage and exits without being recognized by $\mathrm{Mr}$. Ford, although Mr. Ford hits him thinking that he is the witch from Brentford. The architecture of the theatrical building in Almagro provides an excellent setting to perform the actions in the play without having to resort to any other features of the set.

Pericles and The Merry Wives of Windsor did not introduce any significant alterations to the performing space of the Corral. On the contrary, they integrated their action into the characteristics of the venue. Other Shakespearean productions have made more drastic modifications to this space. In The Taming of the Shrew (dir. Carlos Marchena, 1999), a white backcloth covered the whole facade of the tiring house, which was concealed or visible depending on how it was illuminated. Four years later, Troilus and Cressida (dir. Francisco Vidal, 2003) also employed a white cloth for the opening scene, although this one had a maroon circle in the center and covered the front of the stage. The cloth was removed after the Chorus's opening speech.

The most radical modification of the Corral took place with Cheek by Jowl's Troilus and Cressida in 2008, when the spatial configuration of the venue was completely altered. Instead of using the actual stage, as previous Shakespearean productions had done, the stage space was expanded to form a T-shaped traverse stage, with a platform across the patio connecting with the real stage, while the facade of the tiring house was covered with some strips of canvas stained with faded blood. This particular use of the space emphasized the spectacular aspect of the production, shifting the attention from its linguistic component (it was performed in English with Spanish surtitles) to its visual dimension.

Troilus and Cressida was detached from the historical origin of the play in a way that the first production of the company at the festival, Pericles, was not. Troilus and Cressida addressed present day reality, with the characters in contemporary attire and with some of them updated to resemble recognizable character types. A part from an 
openly gay Thersites, Helena and Paris were transformed into Hollywood-like stars. However, in Cheek by Jowl's style, the production kept the simplicity of the setting, mostly restricted here to some stools. This was combined with more unusual stage conventions, such as the performance of soliloquies with characters not in isolation, but surrounded by others who were immobile while the speeches were delivered.

If the performance of Cheek by Jowl's Pericles in the Corral allows for a comparison between Golden Age and Elizabethan venues, a third space comes into view in Troilus and Cressida: a more contemporary kind of performing space, that of the traverse stage. Most of the action took place in the traverse stage, enabling the actors to exit the performance space just by moving to the stage of the Corral. The real stage was only restored to its original function in a metatheatrical moment, when a transvestite Thersites sang to the Trojan Warriors in a Marlene Dietrich style. As the performing space was rearranged, the distribution of the venue was reconfigured, with the audience seating in rows of chairs along the traverse stage in the patio and the balconies. This distribution enhanced the stageauditorium relationship as the audience was even closer to the performers, who addressed them directly and went down the stage invading the audience's space at some moments. The constructedness of theater was highlighted by the distribution, as the spectators faced one another and those in the row next to the stage were illuminated by the stage lighting. This effect was suppressed for soliloquies, when the light intensity was lowered to isolate the characters from the audience and achieve a more emotional introspection.

Cheek by Jowl's intervention in the space transformed the concept of attending a play in this venue. As Ric Knowles notes, "all performances take place within specific architectural and geographic frames that serve to shape their meaning" $(2004,66)$. While the geographical frame of Troilus and Cressida is quite specific (the performance takes place in Almagro, in the Corral de Comedias, in the main square of the town), a multiplicity of architectural spaces are juxtaposed in the performance: two physical spaces (the Corral as a building plus the addition of the traverse stage), and a fictional space (an evocation of Elizabethan playhouses through the play and Cheek by Jowl's staging). This simultaneity of fictional and physical 
spaces, common to all the Shakespearean productions in the Corral examined here, recalls Michel Foucault's concept of heterotopias. According to Foucault, heterotopias juxtapose different incompatible spaces in a single real space. To exemplify this, Foucault precisely comments on what happens in theater, "the theatre brings onto the rectangle of the stage a whole series of places that are alien to one another" $(2008,19)$. Shakespearean productions in the Corral do not only conjure on the stage those fictional places that appear in the plays, they also juxtapose the fictional space of Elizabethan venues and real physical spaces-the Golden Age venue itself and, in the case of Troilus and C ressida, the addition of the traverse stage.

Experimentation with original practice techniques is not frequent at the Corral de Comedias, either with Golden Age works or with Shakespeare. However, the performance of Shakespeare's plays in an original seventeenth-century venue activates the resonances of space encoded in the playtext, foregrounding the relationship between the text and the venue for which they were written in a foreign theatrical space of similar characteristics. With its profusion of Shakespearean productions, the Almagro Festival does not only place the works of the English playwright in direct conversationand competition-with those by Golden Age authors, but also gives rise to a unique theatrical event bringing together Golden Age, Elizabethan theater and contemporary Shakespearean performance.

\section{References}

Allen, John J. 1990. "The Spanish Corrales de Comedias and the London Playhouses and Stages." In N ew Issues in the Reconstruction of Shakespeare's Theatre, edited by Franklin J. Hildy, 207-35. New York: Peter Lang.

Bate, Jonathan. 1997. The G enius of Shakespeare. London: Picador.

Berenguer Ángel, and Manuel Pérez. 1998. Tendencias del teatro español durante la transición política (1975-1982). Madrid: Biblioteca Nueva.

Carlson, Marvin. 1989. Places of Performance: The Semiotics of Theatre A rchitecture. Ithaca, London: Cornell University Press.

- - - 2001. The H aunted Stage: The Theatre as M emory M achine. Ann Arbor: University of Michigan Press.

Carson, Christie, and Farah Karim-Cooper, eds. 2008. Shakespeare's Globe: A Theatrical Experiment. Cambridge: CambridgeUniversity Press. 
Delgado Laguna, Felipe, and Isidro G. Hidalgo Herrero. 2006. "A condicionamiento del Corral de AImagro. 2003-2004." In EI corral de comedias: espacio escénico, espacio dramático, A ctas de las XXVIII Jornadas de teatro clásico de Almagro, edited by Felipe $B$. Pedraza Jiménez, Rafael González Cañal, and Elena Marcello, 139-56. Almagro: Ediciones de la Universidad de Castilla la Mancha.

Foucault, Michel. 2008. "Of Other Spaces." In H eterotopia and the City: Public Space in a Postcivil Society, edited by Michiel Dehaene and Lieven de Cauter, 13-29. London: Routledge.

García de León Álvarez, Concepción. 2000. "La construcción del Corral de Comedias de Almagro." In Francisco de Rojas Zorrilla, poeta dramático: actas de las XXII Jornadas de Teatro Clásico, A Imagro 13, 14 y 15 de julio de 1999, edited by Felipe B. Pedraza Jiménez, Rafael González Cañal, and Elena E. Marcello, 17-38. Almagro: Instituto A Imagro de Teatro Clásico.

García Lorenzo, Luciano, and Manuel Muñoz Carabantes. 1997. “Festival de Almagro: veinte años de teatro clásico." In Festival Internacional de Teatro Clásico de A Imagro. 20 años: 1978-1997, edited by Luciano García Lorenzo and A ndrés Peláez Martín, 63-96. Toledo: Caja de Castilla la Mancha.

González, José Manuel. 1999. "Shakespeare in Almagro." In Shakespeare in Japan, edited by Tetsuo Anzai et al., 244-60. Lewiston: Edwin Mellen Press.

Gregor, Keith. 2005. "Contrasting Fortunes: Lope in the UK/ Shakespeare in Spain." IIha do D esterro 49: 240-41.

_-_. 2010. Shakespeare in the Spanish Theatre: 1772 to the present. London: Continuum.

Gurr, Andrew. 2009. The Shakespearean Stage: 1574-1642. $4^{\text {th }}$ ed. Cambridge: Cambridge University Press.

Hildy, Franklin J. 2004. "The Corral de Comedias at A Imagro and London's Reconstructed Globe." In Shakespeare and the M editerranean: The Selected Proceedings of the International Shakespeare Association World Congress, Valencia 2001, edited by Thomas Clayton, Susan Brock, and Vicente Forés, 89-120. N ewark: University of Delaware Press.

Ichikawa, Mariko. 2002. Shakespearean Entrances. New York: Palgrave Macmillan.

Karim-Cooper, Farah, and Tiffany Stern, eds. 2013. Shakespeare's Theatres and the Effects of Performance. London: Bloomsbury.

Knowles, Ric. 2004. Reading the M aterial Theatre. Cambridge: Cambridge University Press.

McAuley, Gay. 2000. Space in Performance: Making Meaning in Theatre. Michigan: University of Michigan Press. 
Guerrero

Peláez Martín, Andrés. 1997. "El Corral de Comedias de Almagro: un espacio y un patrimonio dramático recuperados." In Festival Internacional de Teatro Clásico de A Imagro. 20 años: 1978-1997, edited by Luciano García Lorenzo and Andrés Peláez Martín, 18-32. Toledo: Caja de Castilla la Mancha.

Portillo, Rafael, and Manuel J. Gómez-Lara. 1994. "Shakespeare in the New Spain: or What You Will." In Shakespeare in the N ew Europe, edited by Michael Hattaway, Boika Sokolova, and Derek Roper, 208-20. Sheffield: Sheffield A cademic Press.

Prescott, Paul. 2008. "Declan Donnellan." In The Routledge Companion to Directors' Shakespeare, edited by John Russell Brown, 69-85. London: Routledge.

Ruano de la Haza, José M. 2000. La puesta en escena en los teatros comerciales del Siglo de O ro. Madrid: Editorial Castalia.

_-_ and John J. Allen. 1994. Los teatros comerciales del siglo XVII y la escenificación de la comedia. Madrid: Castalia.

Rufford, Juliet. 2015. Theatre and Architecture. Basingstoke: Palgrave Macmillan.

Ruiz Ramón, Francisco. 1988. “Del teatro español de la transición a la transición del teatro (1975-1985)." In La cultura española en el posfranquismo: diez años de cine, cultura y literatura en España, 1975-1985, edited by Samuel Amell and Salvador García Castañeda, 103-13. Madrid: Playor.

Sánchez, Alberto. 1992. "A proximación al teatro de Cervantes." In Cervantes y el teatro, Cuadernos de Teatro Clásico 7: 11-30.

Somoza, José Carlos. 1999. Miguel Will. Translated by Keith Gregor. Unpublished.

Thacker, Jonathan. 2007. A Companion to Golden A ge Theatre. Woodbridge: Tamesis.

Ubbersfeld, Anne. 1999. R eading Theatre. Toronto: Toronto University Press.

\footnotetext{
How to cite this article:

Guerrero, Isabel. "Shakespeare in La Mancha: Performing Shakespeare at the Almagro Corral." SED ERI 27 (2017): 27-46.

A uthor's contact: isaesbel@gmail.com

Postal address: Dpto. de Filología Inglesa - Campus de la Merced - C/ Santo Cristo 1 30001 Murcia, Spain

Submission: 07/ 12/ $2016 \quad$ Acceptance: 25/ 02/ 2017
} 


\title{
Translation of temporal dialects in the dubbed versions of Shakespeare films ${ }^{*}$
}

\author{
Ana María Hornero Corisco \\ U niversidad de Zaragoza, Spain
}

\begin{abstract}
This paper intends to providea thorough analysis of some linguistic features of Early Modern English present in three Shakespeare movies and how they have been transferred in the Spanish translation for dubbing. To achieve it, a close observation of forms of address, greetings and other archaic formulae regulated by the norms of decorum of the age has been carried out.

The corpus used for the analysis: Hamlet (Olivier 1948) and M uch A do about N othing (Branagh 1993), highly acclaimed and rated by the audience as two of the greatest Shakespeare movies. A more recent version of Hamlet (Branagh 1996) - the first unabridged theatrical film version of the playwill be analyzed too in the light of the translation choices, and the results will be compared with those of the other two films.
\end{abstract}

KEYWORDS: Shakespeare; Hamlet; Much Ado about Nothing; audiovisual translation; literary films; temporal dialects.

\section{La traducción de los dialectos temporales en las versiones dobladas de las películas shakespearianas}

RESUMEN: El objetivo del presente artículo es analizar en detalle algunas de las formas lingüísticas del Inglés Moderno Temprano presentes en tres películas de temática shakesperiana, y el modo en que se han vertido en la traducción para el doblaje al español. Para ello se ha llevado a cabo un estudio de las formas de cortesía, saludos y otras fórmulas arcaicas reguladas por las normas del decoro de la época.

El corpus analizado incluye $\mathrm{Hamlet}$ (Olivier 1948) y M uch A do about $N$ othing (Branagh 1993), consideradas por el público y la crítica como dos de las mejores películas de obras de Shakespeare. En

\section{A tradução de dialetos temporais nas versões dobradas de filmes shakespearianos ${ }^{* *}$}

RESUMO: O presente artigo visa proceder a uma análise detalhada de algumas formas linguísticas do inglês do princípio da Idade Moderna em três filmes de temática shakespeariana e do modo como estas foram traduzidas para a dobragem em espanhol. Para esse efeito, levou-se a cabo um estudo atento de fórmulas de cortesia e de cumprimento, assim como de outras fórmulas arcaicas reguladas pelas normas de decoro da época.

$\mathrm{O}$ corpus analisado inclui $\mathrm{H}$ amlet (Olivier 1948) e M uch A do about N othing (Branagh 1993), considerados pelo público e pela crítica como dois dos melhores filmes de obras de Shakespeare. A nalisa-se também

\footnotetext{
* This research has been carried out within the framework of Project 245 212/2, funded by the Regional Government of A ragón.
}

** Translation into Portuguese by Miguel Ramalhete. 
tercer lugar, se ha analizado también una versión más reciente de $\mathrm{H}$ amlet (Branagh 1996), la primera versión íntegra de la obra teatral llevada a la gran pantalla, con una reflexión sobre las decisiones tomadas en la traducción, comparándolas en algunos casos con las adoptadas en las dos primeras.

PALABRAS ClAVE: Shakespeare; Hamlet; Much Ado about Nothing; traducción audiovisual; películas literarias; dialectos temporales. uma versão mais recente de $\mathrm{H}$ amlet (Branagh 1996) - a primeira versão integral desta peça para cinema-à luz das escolhas de tradução, e os resultados serão comparados com os dos outros dois filmes.

PALAVRAS-CHAVE: Shakespeare, Hamlet, Much Ado about Nothing, tradução audiovisual, filmes literários, dialetos temporais.

\section{Introduction}

The present article deals with language variation in literary films. Of all the types of dialects which have been traditionally distinguished - geographical, temporal, social, standard/nonstandard and idiolects (Hatim and Mason 1990, 39-45; Agost 1999, 127-31)-this paper focuses on temporal dialects. Temporal dialects show language variation through time and the linguistic uses and fashions of one period or another. In the same way as the reader must come to terms with the language of the time in order to read the literature of the past, the translator must have a solid linguistic background of the source and target languages and then "determine whether an imitation of the source-text style could be an appropriate way of achieving the intended function and what effect this will have" (Nord 1997, 93). The translator of audiovisual products faces the problem of having to transfer some of the morpho-syntactic structures, lexical choices and word order patterns of an earlier period (as many as the film adaptation retains in the original version) to the norm and uses of the target language. The aim of this paper is to analyze some of the Early Modern English forms present in the films and look into the tools employed by the audiovisual translator to give a linguistic flavor of Shakespeare's language in the Spanish dubbed version.

\section{Corpus}

Initially, the films analyzed for this piece of research were $\mathrm{H}$ amlet (Olivier 1948) and M uch A do about N othing (Branagh 1993), highly acclaimed and rated by the audience as two of the greatest 
Shakespeare movies. $^{1}$ A tragedy and a romantic comedy, respectively, both are the first sound films of the plays in English. As a matter of fact, $\mathrm{M}$ uch $\mathrm{A}$ do about $\mathrm{N}$ othing is one of the most financially successful Shakespeare films ever released and Olivier's $\mathrm{H}$ amlet is the Shakespeare film that has received the most prestigious awards. The analysis of these two productions has been recently enriched with that of a third added to the corpus: $\mathrm{H}$ amlet (Branagh 1996), one of the best Shakespeare film adaptations ever made.

\section{M ethodology of analysis}

This paper intends to look into the use and meanings of the forms of address offered in the original (English) version of the three films, seeing in detail, in the first place, the use of second person pronouns as well as the use of titles and how they have been transferred in the Spanish translation for dubbing. Secondly, greetings, expressions of farewell and other Early Modern English linguistic forms that appear in the threefilms will be analyzed.

Several viewings of the three films were initially carried out, followed by a thorough collection of the linguistic forms to be analyzed. The observation of the treatment of such forms in the OV

\footnotetext{
${ }^{1}$ M uch A do A bout N othing (1993) was nominated for the Palme d'Or at Cannes Film Festival the same year. In 1994 it won the London Critics Circle Film Awards for British Producer of the year. It was also nominated Best Feature by the Independent Spirit A wards (1998).

Olivier's H amlet (1948) was the first British film to win the Academy A ward for Best Picture. It received the award for Best Actor, as well as the Golden Lion at the Venice Film Festival, among other prizes. It is also the first sound film of the play in English. However, it proved controversial among Shakespearean purists, who felt that Olivier had largely altered the four-hour play into just two hours' worth of content.
}

Branagh's Hamlet (1996) was nominated by the Academy in 1997 for Best Writing, Screenplay Based on Material Previously Produced, Best Art Direction-Set Decoration, among others. It was also nominated for BAFTA Film Awards (1997); for the detail of all the nominations and awards, see http:/ / www.imdb.com/ title/ tt0116477/ awards (last accessed August 2017). Critics in Spain referred to it as a stunning adaptation of Shakespeare's text where Branagh displayed his talent in an awesome masterpiece. However, the film went al most unnoticed in Spain, probably due to its unusual length (four hours) and to its markedly literary script. Actually, as Pedro Moral (2016) has pointed out, Shakespearean films have been real box-office successes in Spain are precisely those which have least to do with the writer's style (as is the case of Shakespeare in Love or Romeo and Juliet). 
and the $\Pi T$ versions reveals to what extent the Spanish translation for dubbing in the three films succeeds in conveying the meaning intended by the playwright and in contributing to take the audience back to the Renaissance. The study also includes considerations on the translation techniques applied. Last but not least, Astrana Marín's literary translation has been taken as a helpful reference for comparison with the dubbed product.

\subsection{A nalysis of forms of address}

\subsubsection{Second person pronouns in Early Modern English and their translation}

Among the linguistic tools used in Early Modern English that showed the relationship between the characters the second person pronoun usage stands out. In Elizabethan English there was a choice between the familiar th- and the deferential $y$ - to refer to a singular addressee, a use dating from the thirteenth-century. Since then, the second person plural forms ( $y$-forms) began to be used with a singular meaning in circumstances of politeness or formality (Algeo 2010; Blake 1996, 219; Corrie 2006, 107; Görlach 1991, 85).

The analysis takes into account two concepts used by Brown and Gilman (1989) for their most influential study of address forms: the power pronoun semantic and the solidarity semantic; the polite or $y$ form would be used to address a singular social superior as well as an equal who belonged to the upper classes. Therefore, $y$-forms were used to indicate social distance or respect. The original singular thforms would be used to address a social inferior as well as for reciprocal address among the lower classes.

In Early Modern English there was a remarkable fluctuation between 'you' and 'thou' to address a single hearer, frequently expressing thereby shifts of feeling. Thus, the th- form gradually acquired the condition of marked form, associated with a rising of emotional temperature in a social interaction and connoting passion, familiarity, or disrespect, all context-bound interpretations. 'You', in turn, would be reserved for public, fashionable and polite address. The bases of power are varied: gender, age, social status, etc. Power equals would be expected to give and receive the same pronoun (Hornero Corisco 2006). 
In Present Standard English, however, there is only one form, 'you', with a singular or plural value. The use of 'you' as the only pronoun of address obscures those former differences of number and of social status which are still maintained in other European languages. $^{2}$

As Hatim and Mason state (1997, 68; Mason 2001) transferring the meaning of the shift between the two personal pronoun forms is a familiar problem for screen translators:

in languages which have distinct pronouns of address to encode addresser/ addressee relationship [...] a switch from the use of one form to the other form may in itself constitute a potential FTA - to the addressee because the sudden reduction of the social distance between him or her and the speaker may be unwelcome; and to the speaker because he or she runs the risk of being rebuffed by nonreciprocal use by addressees.

As to the forms of address in Spanish at the time, Fontanella de Weinberg $(2000,1412)$ states that 'vos' still worked as a respectful form of address in formal contexts, in what was known as its "ancient use," given that it kept the characteristic value of 'vos' in the Middle Ages. Similarly, Frago García underlines the fact that "las formas de tratamiento de respeto dedicadas al superior o que entre sí se intercambian los miembros de la minoría dominante sean 'vuestra señoria', 'vuestra merced' o 'vos' realzado por un vocativo de respeto" (2005, 300). Moreover, the need to show a higher degree of affection or camaraderie or even the intention to denigrate the addressee would lead to a shift in the use of the pronominal forms, and here the Spanish t-forms could fulfil the goal (Frago García 2005, 296).

Before proceeding with the analysis it must be clarified that the totality of $t$ - and $y$ - forms in English and their translation into Spanish in the three films has been considered. Astrana Marín's translation has been provided in those cases where it succeeds in

\footnotetext{
${ }^{2}$ It is a fact, however, that outside the standard, some varieties of English (N evalainen 2006, 194) establish a useful formal distinction between a single and plural addressee, although these data are not generally acknowledged by contemporary grammarians. These variants are not usually recorded, except in colloquial registers. Katie Wales (1996) offers a thorough study on (non)-standard pronoun forms from a pragmatic and functional point of view.
} 
taking the reader back to Shakespeare's days, as a contrast to what is seen in the translation for dubbing.

\section{Much A do about Nothing}

Of the total number of $y$-forms (24) in the comedy M uch A do about $\mathrm{N}$ othing, all are translated as $\mathrm{v}$-forms in Spanish, as in

Example 1 (00:11:20)

[Leonato to Don John]

OV: Let mebid you welcome, my lord.

$\Pi$ T: Dejad que os déla bienvenida, señor.

The translation maintains, in this sense, the deferential form of the original line. Notice also that the v-form chosen, 'vos', is archaic in Spanish now, 'usted' being the form currently used.

Figure 1. The translation of $\mathrm{y}$-forms in $\mathrm{M}$ uch $\mathrm{A}$ do about $\mathrm{N}$ othing

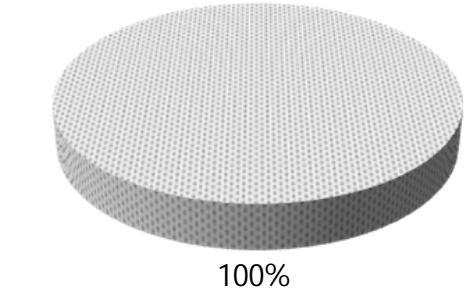

V-forms t-forms $\mathrm{N}$ ot translated

There is, therefore, consistency in the translation of y-forms, the expected treatment from Speaker to Hearer (henceforth $\mathrm{S}$ and $\mathrm{H}$ ). The use of a v-form provides a flavor of earlier times, as the translator has chosen an earlier (no longer used) form of Spanish.

Moreover, there is not a single occurrence of the 'ye' form in the original version. In Early Modern English 'ye' was frequently used as the subject (either with a plural meaning ('you') or with a singular, deferential function). The script writer may have thought it to be too archaic, too strange to a twentieth-century audience, overlooking the historical linguistic evidence and trying instead to 
attract the general audience with a more accessible linguistic product.

As to the th-forms (35) in M uch Ado about $\mathrm{N}$ othing, eight are translated as t-forms (22.8\%), as in the scene when Dogberry, the constable of Messina, addresses Borachio-one of Don John's associates-in a clear attempt to abuse the knave under arrest using linguistic means.

Example 2 (01:13:00)

OV: I do not like thy look, I promise thee.

TT: No me gusta tu facha, te lo aseguro.

Or, when Beatrice holds an imaginary conversation with Benedick in which she declares her love for him.

But the majority (23) are translated as v- forms (65.7\%), as shown in Figure 2.



Example 3 (00:12:49)

[Claudio to Benedick]

OV: Thou thinkest I am in sport. I pray thee, tell me truly how thou likest her.

TT: Creéis que no hablo en serio. Quiero saber lo que de verdad opináis.

This option reveals that in the Spanish dubbed version there is a breach in the linguistic norm. The English version shows the 
closeness of two friends, by means of the th-forms, but this proximity disappears in the Spanish translation. The translation is not conditioned by lip synchrony or time restrictions. In Astrana Marín's literary translation, however, "Piensas que estoy de broma. Te suplico me digas con franqueza lo que te parece" (1974, 12), the intended closeness is evidenced.

The following example shows that when they are courting, Benedick addresses Beatrice with th-forms, but this intimacy is not reflected in the translation for dubbing, so the Spanish audience cannot perceive this shortening of distance expressed by linguistic means:

Example 4 (01:31:49)

OV: I will live in thy heart, die in thy lap and be buried in thine eyes. And moreover, I will go with thee to thy uncle's.

$\Pi$ T: Quiero vivir en vuestro corazón, morir en vuestro seno y ser enterrado en vuestros ojos. Y además, ir con vos a ver a vuestro tío.

Notice that the $T$ presents a longer discourse and lip synchrony is not taken into account, even though this is a medium close-up shot. The soundest reason for the recurrent translation of th- as v-forms in the dubbed version may be the intention to take the audience back to the Renaissance, and in order to achieve it a touch of formality is given to the discourse between $\mathrm{S}$ and $\mathrm{H}$ with the aid of these pronominal forms. The original version presents friends 'th-aging' each other (e.g., Claudio to Benedick, Don Pedro to Benedick, Benedick to Don Pedro, Don Pedro to Claudio); a person with a higher position in the social scale to another on a lower step; and lovers in an intimate situation. The Spanish audience cannot perceive, however, the companionship between speaker and addressee that the English version makes explicit by means of the use of the more friendly th-forms. Moreover, shifts of address between characters are revealed by these linguistic means in the original version. Thus, Benedick addresses Don Pedro (a close friend of his) with a deferential $y$ - in public, showing by this means respect for his higher rank but also anger, marking distance when he does not agree with Don Pedro's behavior.

Example 5 (01:17:57)

OV: My lord, for your many courtesies I thank you. 
TT: Alteza, os agradezco vuestras cortesías

At the end of the play, however, the spirit of camaraderie is recovered in the source text, with a return to a th-form that Benedick utters addressing Don Pedro again as a friend:

Example 6 (01:39:56)

OV: Get thee a wife!

TT: ¡Buscaos esposa!

The shift of treatment is not reflected in the translation for dubbing, so the Spanish audience is not aware of that change in mood between $\mathrm{S}$ and $\mathrm{H}$. Notice, however, that Astrana Marín's translation does reflect the intended shift: “¡búscate mujer!” (1974, 61).

\section{Olivier's Hamlet (1948)}

Of a total number of $36 \mathrm{y}$-forms in Olivier's $\mathrm{H}$ amlet thirteen (36.1\%) are translated as v-forms in Spanish, $17(47.2 \%)$ as t-forms and six were not translated as a form of address (16.7\%).

Figure 3. The translation of $\mathrm{y}$-forms in Olivier's $\mathrm{H}$ amlet

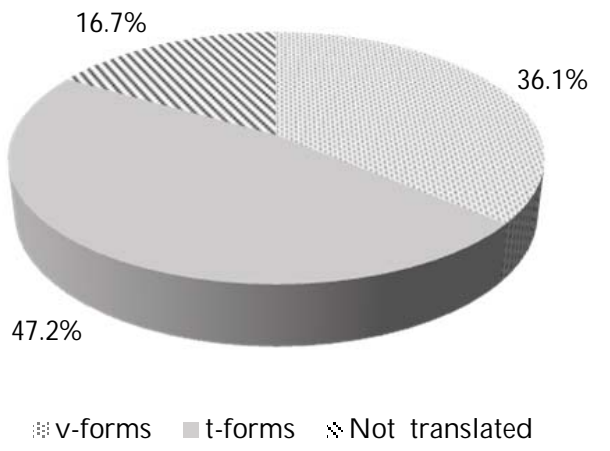

Only one v-form and three th-forms have been included in the target text where none of them is found in English; moreover, they cannot be considered as instances of compensation in the translation of this audiovisual text.

Noteworthy is the fact that the King addresses Hamlet with yforms in public, following the linguistic etiquette to show respect to a prince, even if the speaker is the highest authority. Moreover, the 
use of the 'royal we' formula - the purpose of which is to mark the speaker's authority, a sense of his own importance-accompanies the speech of King Claudius in Olivier's film version:

Example 7 (00:11:08)

[King to Hamlet, in public]

OV: But now, our cousin Hamlet, and our son, ${ }^{3}$ how is it that the clouds still hang on you?

$\Pi$ T: $Y$ ahora, sobrino Hamlet e hijo nuestro, ¿por qué se ciernen sobreti esas nubes?

Immediately after this, the queen addresses Hamlet with th-forms, showing tenderness and a higher degree of affection:

Example 9 (00:11:20)

[Queen to Hamlet, in public]

OV: Good Hamlet, cast thy nightly colour off and let thine eye look like a friend on Denmark.

$\Pi T$ : Buen Hamlet, deja ya tu negro luto, ven como amigo al rey de Dinamarca.

The translation does not distinguish between king and queen, using the t-form in all cases. We observe in this film a greater percentage of occurrences in which the $y$-form has been rendered as a t-form in the Spanish translation for dubbing. This is not the case in M uch A do about $\mathrm{N}$ othing, as seen above.

The translator possibly opted for t-forms in these cases to show affection from the $\mathrm{S}$ to the $\mathrm{H}$ (King to Laertes, King to Hamlet, Queen to Hamlet, etc.).

At this point it is worth observing how the translation for dubbing reflects interesting differences in address between characters-such as those illustrated above-and shifts of address of the same $\mathrm{S}$ towards the $\mathrm{H}$, as in the following cases:

${ }^{3}$ The "royal we" is not present here in Branagh's version (in fact, it is not present in the Folio), but the addressee receives a t- form in Spanish, too. Example 8 (00:13:58):

OV: But now, my cousin Hamlet, and my son [...] how is it that the clouds still hang on you?

TT:Y tú mi sobrino, Hamlet, y también mi hijo [...] ¿cómo es que sigues aún con ánimo tan sombrío? 
At the official reception the King first addresses Laertes by means of a respectful $y$-form in public, but then switches to a th-form, perhaps trying to approach him more affectionately. The translation, however, does not make a difference-showing a t-form in all cases. With this levelling in the translated product the audience is missing changes in the characters' mood.

A thorough analysis of the $T T$ reveals another example and of special interest: the scene in the queen's closet, after the theatre performance. She rebukes her son for having offended the king with the performance:

Example 10 (01:26:12)

[Gertrude and Hamlet]

OV

HAMLET N ow, mother, what's the matter?

QUEEN Hamlet, thou has thy father much offended.

HAMLET Mother, you have my father much offended.

QUEEN Come, come, you answer with an idle tongue.

HAMLET Go, go, you question with a wicked tongue.

The queen starts talking to Hamlet as a mother natural ly talks to her son, affectionately. Then she switches to a y-form in reproach, showing distance. Hamlet uses the respectful and distant ythroughout the exchange, although the Spanish audience hears the tform and is therefore unable to perceive these nuances of feeling conveyed by linguistic means.

$\pi$

HAMLET Madre, ¿quéte ocurre?

QueEN Hamlet, has ofendido gravementea tu padre.

HAMLET Eres tú quien ha ofendido a mi padre.

QUeEN Vamos, vamos, respondes con lengua insolente.

HAMLET venga, venga, preguntas con lengua perversa.

As all her speech is translated uniformly, her t-treatment to Hamlet unaltered, the audience misses some revealing changes in her mood with respect to her son. 
Similarly to what has been commented for M uch Ado about $\mathrm{N}$ othing, there are no occurrences of the ye form in this film, as presumably the script writer thought it would sound too archaic and difficult to understand by the general audience. Where 'ye' is expected, 'you' replaces it.

Most of the th-forms of address in Olivier's version are translated as t- in Spanish: 35 (92.1\%), and only one is translated as v- (2.6\%). Two are not translated (5.3\%).

Figure 4. The translation of th-forms in Olivier's $\mathrm{H}$ amlet

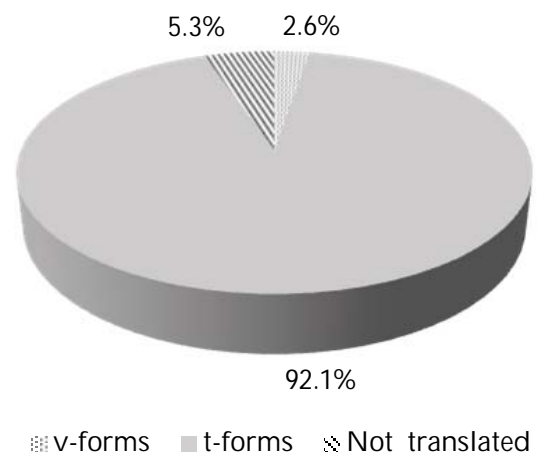

\section{Branagh's Hamlet (1996)}

The fact that Olivier's $\mathrm{H}$ amlet made many alterations and excisions to the play sparked controversy among Shakespearean purists. Moved by curiosity as to how different the results could be in the 1996 film, released nearly 50 years later than Olivier's, this version, the first unabridged theatrical film version of the play, running for 232', was the third to be analyzed. Among the four Academy Award nominations the film received, one went for its adapted screenplay, by Kenneth Branagh. The lines are based on Shakespeare's 1623 Folio.

The analysis showed that a total number of 183 y-forms in Branagh's film Hamlet (38.44\%) are translated as v-forms in Spanish (compare to $36.1 \%$ in Olivier's). Despite the long span of time between both film versions of $\mathrm{H}$ amlet, there is not a remarkable difference in the treatment of the $y$-forms in the Spanish dubbed version. 
Figure 5. The translation of y-forms in Branagh's $\mathrm{H}$ amlet

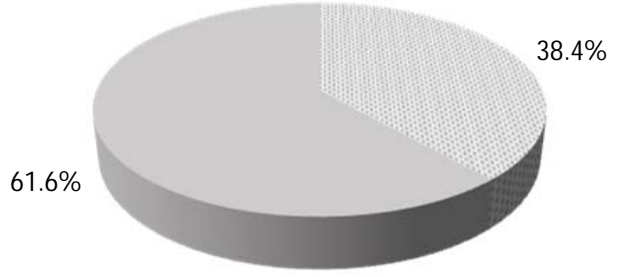

v-forms $\square$ t-forms

A larger percentage, $61.55 \%$, are translated as t-forms (293) (compare to $47.2 \%$ in Olivier's). Here the difference is more marked. Looking into the reasons that lead to this percentage difference we discover that the length of the film itself is the answer: the passages where Polonius holds a conversation with Reynaldo, or Hamlet with Rosencrantz or Guildenstern are omitted in Olivier's version. Similarly, the long conversations held between Polonius and his son Laertes, then with his daughter Ophelia or the dialogue between brother and sister are markedly shorter in the 1948 version of the film. These and more passages showed the deferential $y$ - in the original English version but have been transferred into Spanish by means of the t-form, which conveys a higher degree of closeness between $\mathrm{S}$ and $\mathrm{H}$, a more patronizing mood on behalf of the $\mathrm{S}$, or camaraderie between the two characters involved.

Branagh's film also provides interesting changes in mood in some characters, conveyed by linguistic means. As an example, in Act 3, Scene 1, after Hamlet's soliloquy, there is an encounter between Hamlet and Ophelia. She addresses Hamlet with y-forms (showing respect for the prince), which are translated as v- forms in Spanish:

Example 11 (01:33:31)

OV: OPHELIA My lord, I have remembrances of yours that I have longed long to redeliver. I pray you now receive them.

$\Pi T$ : Señor, tengo recuerdos que me disteis y que hace tiempo deseo devolveros. 0 s ruego que los aceptéis. 
Hamlet, however, moves from an initial y-:

Example 12 (01:34:19)

OV: Areyou honest? (...) A reyou fair?

$\Pi$ : ¿Eres honesta? (...) ¿E res bella?

to th- in anger:

(01:35:58)

OV: If thou dost marry, I'll give thee this plague for thy dowry: be thou as chaste as ice, as pure as snow, thou shalt not escape calumny. Get thee to a nunnery, go, farewell.

$\Pi T:$ Si alguna vez te casas ésta será mi maldición para tu dote: que tú, casta como el hielo, pura como la nieve, no logres escapar a la calumnia. Vete a un convento, ve, adiós.

And then goes back to $y$ - in the English version, despising Ophelia.

The Spanish dubbed version does not reflect that change in mood, employing t-forms from the beginning. As a result the Spanish speaking audience misses part of Shakespeare's intended meaning.

The th-forms of address in Branagh's version are mostly translated as t- in Spanish: 233 (94.33\%) (compare to 92.1\% in Olivier's).

Figure 6. The translation of th-forms in Branagh's $\mathrm{H}$ amlet

$5.7 \%$

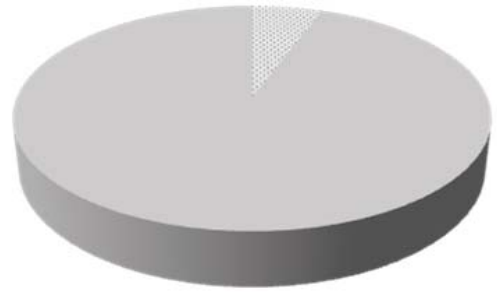

$94.3 \%$

v-forms t-forms 
Worth mentioning here is the fact that the ghost is addressed as 'thou', possibly in fear. 'Thou' was found in dramatic address and invocation to (super-) natural forces (Wales 1996, 77). The Spanish translation renders the corresponding $\mathrm{t}$ - form:

Example 13 (00: 03:07)

OV: HORATIO By heaven, I charge thee speak.

$\Pi$ : Por el cielo, te conjuro a que hables.

Only fourteen th-forms of address (5.66\%) are translated as v-forms in Spanish. Despite the much greater amount of data retrieved from the four-hour running film, and the five decades that separate the two versions of $\mathrm{Hamlet}$, it seems that there is not a remarkable difference in the translation of these forms of address into Spanish.

\subsubsection{Titles}

The expressions of deference in Shakespearean English could be accomplished by means of substrategies like the use of titles, regarded as particular forms of address. The status of the addressee would determine the choice of one or another form. According to Brown and Gilman $(1989,175)$ names with one honorific adjective would score points for deference and titles adorned with honorific adjectives would score higher than the former.

\section{Much A do about Nothing}

Eleven different forms appear in $M$ uch $A$ do about $N$ othing. Only the Duke Don Pedro receives the treatment 'Your Grace', translated as 'Vuestra Gracia'. Don Pedro and Don John receive the title 'my lord' or variant forms, translated as 'señor'. Curiously, Claudio is addressed with the more polite form 'dear my lord' ('mi querido señor') by Leonato, when the latter addresses him as his future sonin-law. Benedick addresses Claudio once as 'boy' ('muchacho'), in a patronising mood. The translations of 'sir' and 'signior' are always levelled in the Spanish form 'señor'. This can be seen when John addresses Claudio in the fancy dress ball (00:25:31) or when Beatrice addresses Benedick, towards the end of the film:

Example 14 (01:29:38)

OV: Yea, signior, and depart when you bid me.

$\Pi T: S i ́$, señor, y partiré cuando lo ordenéis. 
The Italian form 'signior' is never reflected in the $\Pi$, so the Spanish speaking audience misses a bit of the Italian flavor through this strategy of adaptation, which is rather disappointing, given that the film is set in Messina, the Italian town where Don Pedro of Aragon and his noblemen go to visit their friend Leonato. By contrast, Astrana Marín's translation always keeps the loanword 'signior' when it appears: "Sí, signior, y partiré cuando me lo mandéis" (1974, 57) opting for the technique of loanword (Hurtado Albir 2004, 271), thus helping in the contextualization of the play. An explicit reference to Messina is made when the offended Leonato begs Don Pedro and Claudio to restore his beloved daughter's honor:

Example 15 (01:21:44)

OV: But I pray you both tell the people in M essina here how innocent she died

TT: Pero ruego a los dos que declaréis a todo el pueblo de M esina queella murió inocente

\section{Olivier's Hamlet}

$\mathrm{N}$ ine different titles appear in $\mathrm{H}$ amlet. Some show a high degree of politeness. There is elision (Hurtado Albir 2004, 270), however, in the translations of the forms 'Good my lord' and 'Dread my Lord' ', both transferred as 'mi señor' - the title adorned with honorific adjective is thus simplified to the translation of the title.

Four out of nine forms are not felicitous translations of the OV, as in the following example, where part of the addressee has been omitted. Again visual synchrony is not a reason for the change, as Polonius's is an off voice here:

Example 16 (00:42:07)

[Polonius to King and Queen]

OV: My liege and madam.

TT: Soberana señora.

As a result, even though the film presents more polite formulae of address in its English version they are not always rendered as such in the target language. The elision is not present in Astrana Marín's translation: "soberano mio, y vos, señora mía" $(1974,238)$.

\footnotetext{
${ }^{4} \mathrm{~N}$ otice that the modifier is frequently placed before the determiner.
} 


\section{Branagh's Hamlet}

A much greater variety of forms of address pervades this film: different titles, with variant forms, which could be classified into:

Forms relating to the royal rank: each of the members of the royal family deserves specific forms. Thus, the king is addressed as: 'my (good) liege' ('majestad'), 'your highness', 'gracious', 'your majesty' ('vuestra majestad'). The queen as: 'my sweet queen' ('mi dulce Gertrude'), 'my liege and madam' ('mi soberano, mi señora'), 'your grace' ('vuestra gracia'), 'gracious' ('majestad'), '(good) madam' ('señora'), 'my dear majesty' ('mi querida majestad'). These forms are translated with the corresponding equivalent forms in Spanish, and as such they offer no difficulty. However, sometimes one form in Spanish is the translation of several different forms in English (as seen in the case of 'liege', 'majesty' or 'gracious', all translated as 'majestad').

By far the most recurrent of all address forms is 'Lord', with different degrees of formality, ranging from the most formal (to the king): 'Dread my lord' ('respetado señor') to other less formal formulae: 'Dear my lord, good my lord' ('buen señor'), 'my honored lord' ('mi ilustre señor'), 'my lord' ('(mi) señor'), the latter being the most frequent one. The second most frequent is 'Sir', and is always translated as 'señor'. 'Sirrah' reflects a clear distinction between the speaker (well positioned in society, in this case Hamlet) and the addressee, the grave-digger. This form has been replaced with 'sir' in the film script and is not translated.

Literal translation is the translation technique usually applied in the case of titles.

Family forms: 'brother' ('hermano'), 'daughter' ('hija'), 'my son' ('hijo mío'), '(dear) sister' ('querida hermana'), 'mother' ('madre'), always translated literally. The term 'cousin', used by the King to address Hamlet, is only translated once (out of three appearances) as 'sobrino', using a discursive creation technique ("a temporary equivalence which is totally unpredictable out of context") (Molina and Hurtado 2002, 510). As Crystal and Crystal point out, in Shakespeare 'cousin' is used "for virtually any relative beyond the immediate family, both for blood relatives and relatives through marriage, and often as a term of affection between socially equal 
people who are not relatives at all, such as monarchs of different countries" (2002).

Other recurrent forms of address that appear are:

- 'friend(s)' appears in various phrases: 'my (good) friends', 'my old friend', 'your friendship', translated invariably as 'amigo(s)', except for the latter form, which is not translated.

- 'good gentlemen', translated as 'caballeros' (73\%) o 'señores'(17\%).

The term '(dear) lady' finds no translation when Hamlet addresses Ophelia (28\%). It is translated as 'señora' when the Queen is the addressee (28\%), although on one occasion Hamlet addresses her as 'madre' (14\%) in the translation. When the King and Queen speak to the mad Ophelia the translation turns more patronizing: 'sweet lady' 'mi dulce niña' (15\%) or 'pretty lady' ‘linda dama'(15\%).

\section{2. $O$ ther Early M odern English forms}

The film Much Ado about N othing shows nine clearly identifiable Renaissance forms in its OV. Some of them are greetings:

- 'Good day': dated and formal. It is translated as 'buenos días', in current use in Standard Spanish.

- 'Good morrow': archaic, literary or dialectal, referring to the following day. It is translated as the previous formula, 'buenos días', currently in use in Spanish.

Others are expressions used at parting:

- 'Adieu': interjection; archaic form meaning 'goodbye'. It could have been translated as 'Id con Dios', 'con Dios'. But its translation is invariably 'adiós', the current formula in Spanish.

- 'Fare you well, farewell' (interjection, archaic). The S wishes well to the $\mathrm{H}$ at parting: 'may you fare well'. It is translated as 'adiós', the present Spanish expression. As with the previous example, the technique of levelling has been used.

The film displays other forms that were used in Shakespeare's days and sound archaic to the English-speaking audience: 
- 'Ere': preposition, archaic. Translated as 'antes de/ de que'. There is no archaic equivalent in Spanish or any other form in the translation of the sentences affected which compensate for its archaic nature.

- 'Hither': adverb translated as 'aquí', currently in use in Spanish.

- 'Methinks'5 (archaic, the surviving Old English dative construction of 'it seems to me', where 'me' is the indirect object). It could have been translated as 'paréceme' or as an adverb indicating point of view (Palander-Collin 1997, 396). Instead we hear 'os veo'. The translation technique employed here has been that of modulation.

- 'Whither': adverb, archaic. Translated as '¿adónde?', currently in use in Spanish.

- 'Yesternight': translated as 'anoche', current in Spanish.

These examples show that the sporadic Early Modern English forms of the OV do not find a temporal equivalence in the $T$, therefore making them sound contemporary to the audience.

Olivier's Hamlet makes, with its seventeen early forms, a slightly greater effort to take the audience back to the Elizabethan period. The forms interspersed throughout the text are:

An expression of good wishes when somebody leaves:

- 'Adieu': translated as 'adiós'.

- 'Farewell': also translated as 'adiós', the usual formula in present day Spanish.

A variety of Early Modern English forms which are no longer in use. Here they follow, in alphabetical order:

- 'Aught': archaic. Translated as 'nada'.

Example 17 (01:33:44)

\footnotetext{
${ }^{5}$ The process of development of the phrase me thinks to a sentence adverbial started in the early fifteenth century. According to Palander-Collin (1997, 372) "some degree of grammaticalization has taken place in the development of think in Middle and Early Modern English, leading to a gradual adverbialization of the expression me thinks as an indicator of opinion or subjective truth."
} 
I never gave you aught.

Astrana Marín provides a touch of earlier Spanish: "nunca te he dado cosa al guna" (1974, 249).

- 'Ay': interjection, archaic.

Example 18 (00:14:33)

Ay, madam.

Example 19 (01:13:52)

Ay, my good lord.

It has been translated as 'sí' in the first case, and with a touch of earlier days in the second: 'así es, mi señor'.

- 'It comes': expanded verbal forms are not so frequently found in Shakespeare's English. It has been translated as 'ya Ilega', sounding like present day Spanish.

- 'Hither': adverb, archaic.

Example 20 (01:15:06)

OV: the actors are come hither.

TT: Han llegado los cómicos, señor.

'Hither' is not translated; the Spanish audience does not perceive the antiquity of the verbal construction 'are come', either.

- 'Likes': still used as an impersonal verb; not translated.

Example: This likes me well.

- 'List': archaic form for listen, imperative. Translated as 'escucha'.

- 'Methinks', 'methought': The former has not been translated. The latter is translated as 'pensé'.

- 'Mine': variant form of the possessive 'my', uttered when the following words started with vowel. The translation does not take account of this variant form, being rendered as 'mi'.

- 'Nay': dated, archaic. Translated as 'no', current in Spanish.

- 'Our': 


\section{Example 21 (00:16:27)}

OV: our throne

TT: nuestro trono

The 'royal we' was employed by a person of high office, such as a monarch, earl or pope. The pronoun was used by royalty to indicate that they represented both the body natural and the body politic. Hence, the presence of the first person plural pronoun forms: 'we', 'us' and 'our'. Its use can help set the tone of a passage.

Example 22 (00:16:20)

OV: Think of us

TT: Pensad en nos

The translation helps to set the audience in the Renaissance. Astrana Marín translates both as a first person plural form: "nuestro trono" and "nos miréis como a un padre" (1974, 224).

- 'Whence': adverb, literary. Translated as 'de donde'. It does not sound literary or archaic in the translation.

- 'Yesternight': archaic. Compound formed in the Middle English period. Translated as 'la pasada noche', currently in use in Spanish.

- 'Wondrous': we find here the use of a non -ly adverb acting as an intensifier.

Example 23 (00:46:56)

OV: wondrous strange

TT: muy extraño

In twelve cases (70.5\%) the Spanish audience does not hear an archaic form. The expressions 'This likes me well', 'marry' and 'methinks' are not translated. Only in three cases does the translation for dubbing give a hint of early forms: 'Ay' ('así es'); 'yesternight' ('la pasada noche'); the use of the 'royal we' in 'our throne' is translated as 'nuestro trono'; 'think of us' as 'pensad en nos'.

Branagh's Hamlet presents a far greater number of these early forms, as the script is based on the Folio. For reasons of space, unlike for the other two films, a selection of significant Early Modern English forms is presented here. Including all of them in this section 
would doubtless require a paper of far greater length. The need to comply with word count has determined the decision to present some, leaving aside others.

A variety of farewell expressions like the following pervade the film (for the number of occurrences of each form and indication of their translation see table below):

- 'Good night' appears three times in the ST and is translated as 'buenas noches', with no archaic touch. The variant form 'Give you good night', however, is rendered as 'os deseo buenas noches', sounding more formal, most likely due to the presence of they-pronoun.

- 'Farewell' appears 22 times and seventeenth of them are translated as 'adiós', showing no archaic touch. Notice, nevertheless, that when followed by a personal pronoun the translation gives a flavour of the archaic:

ST: Fare ye well $\quad \Pi$ : 'quedad con Dios' (1x)

ST: Fare theewell TT: 'debo despedirmeya' (1x)

ST: Fareyou well TT: 'quedad con Dios' (appearing 3x)

- 'Adieu' appears four times, al ways translated as 'adiós'.

- 'God b'wi'ye' appears three times and finds different translations: 've con Dios', 'andad con Dios', 'te digo adiós'. In this case the translation in Spanish actually sounds more literary and takes the audience back to earlier times, although the association of the forms with the seventeenth-century is not made.

In sum, nine out of the 32 farewell forms (28\%) render a touch of earlier days in the TT.

Something similar happens with greetings:

Example 24 (01:07:45)

OV: How dost thou, Guildenstern?

$\Pi$ T: ¿Cómo estás, Guildenstern?

Notice also here the use in English of a th- personal pronoun and an inflected verbal form, which contrasts with the present Spanish form. 


\section{Example 25 (01:43:36)}

OV: What ho, Horatio!

TT: Hola, Horacio

The translation into Spanish does not show early forms. Astrana Marín provides more formal greetings in Spanish: “¿Cómo te va, Guildenstern?" (1974, 240) and “¿Quién es? ¡Ah!, Horacio” (1974, 252), respectively.

Other greetings pervade the text: 'Holla', 'How is't' + name?, 'How now' +name/ title?, 'How do ye [...]'?, 'How fares' + title? and 'Good morrow, sweet lord', none of them showing archaic forms in Spanish. The exception is 'How does my good lord?' (2x), translated as '¿Cómo estáis, mi buen señor?' Here the presence of the title has conditioned the translation, which achieves a touch of formality.

By way of conclusion, two out of the nineteen greetings (10.5\%) give a touch of earlier days in the $T$.

A part from farewell forms and greetings, there follow a selection of Early Modern English linguistic forms which appear repeatedly in this film.

'Ay': Branagh's version of Hamlet shows 22 times the Renaissance way of asserting, translated as 'sí' in Spanish fifteen times, as in:

Example 27 (00:43:52)

OV: Ay, thou poor ghost

TT:Sí, pobre espectro

Other translations, however, sound more literary and dated (3x): ('eso mismo', 'eso es', 'así es') and on two occasions it is not translated.

There also appear in the audiovisual text double comparative forms, regarded as incorrect since the eighteenth century by grammarians:

Example 28 (01:56:42)

OV: Your wisdom should show itself more richer to signify this to his doctor

TT:Te mostrarías mucho más sabio si se lo contaras al médico 
The technique used here is transposition. There are two occurrences in the ST. The sentence sounds contemporary to the Spanish audience.

In Early Modern English, the inversion verb-object is used not only for interrogations but also in other instances:

Example 29 (00:19:47 CD2)

OV: Thus diddest thou

TT:Tú hiciste esto

The Spanish translation does not put the stress on the manner, but on the person who carried out the action. This sentence also sounds contemporary to the Spanish audience, like any of the ten occurrences where this inversion is present in the ST.

'Mine', the variant form of the determiner ' $m y^{\prime},{ }^{6}$ was preferred when the following word started with a vowel or $\langle h\rangle$, a linguistic choice that originated in Middle English:

Example 30 (00:39:33)

OV: Sleeping in mine orchard.

TT: Mientras dormía en el jardín.

Again, this has no effect in the Spanish translation, where there is no equival ent archaic form. It is not translated in the example, but when it appears in the TT, it does so as ' $m i$ '.

The negative form 'nay' appears fourteen times:

Example 31 (01:10:21)

$\mathrm{OV}$ : $\mathrm{N}$ ay then, I have an eye on you.

$\Pi$ T: No os quitaré el ojo de encima.

Transposition has been used as a translation technique in the example. Again, the Spanish audience does not hear archaic forms here. 'Nay' appears sixteen times in the ST, but it is only translated on four occasions, as 'no'.

\footnotetext{
6 Nevalainen and Raumolin-Brunberg (2003, 142) document the gradual disappearance of $-n$ from the first-and second-person singular possessive determiners in the period 1500-1619, a change which seems to have been led by the lower ranks of society.
} 
The contracted verbal form 'nill', the result of joining 'ne' + 'will', dates back from the Middle English period:

Example 32 (00:29:44 CD 2)

OV: Will henill he

$\Pi T$ : quiera o no quiera hacerlo

The clearly archaic form in English finds a contemporary Spanish translation. Astrana Marín translates 'quieras que no' (1974, 277).

'Perchance', an archaic adverb borrowed in the Middle English period from Old French 'par cheance', meaning 'by chance, possibly';

Example 33 (00:24:37)

OV: Perchance 'twill walk again

TT: Q uizá aparezca otra vez

The technique used is literal translation, showing no trace of its archaic character in the Spanish version. It appears five times in the ST, the translation being always the same. Horatio's reply, however, helps to take the audience back in time:

OV: 'twill walk again

TT: Os aseguro que lo hará.

Astrana Marín opts for an outdated form: 'de seguro', compensating in a way for the absence of other early forms in the translation.

There are 34 occurrences of the 'royal we' formula, with variant forms:

Example 34 (00:09:40)

OV: Hamlet our dear brother's death

TT: La muerte de mi querido hermano Hamlet

Example 35 (00:16:20)

OV: Think of us as of a father

$\Pi T:$ Que pienses en mí como en un padre

Every time the subject 'we' appears in the ST in its use as a 'royal we' (10x), it is rendered as a first person singular in the $\pi$. Likewise, when 'us' appears as a 'royal we' formula (5x) it is translated as 'a 
mí'. The example above shows the translation to Spanish renders the present equivalent in all cases, sounding contemporary to the audience (contrasting with Olivier's film translation, which sounded more archaic in this respect). The same result is obtained in the translation of 'our' and 'ourself', rendered as 'mí' and 'yo mismo', respectively.

Perhaps the most striking early pronoun form is the relativizer 'the which':

Example 36 (00:05:08)

OV: Against the which

TT: A cambio delo cual

'The which' is a relative pronoun which appeared in Late Middle English as a calque from French 'lequel'. The combination was favoured by some writers at that time (Burrow and Turville-Petre $1992,43)$ but as the sixteenth century unfolded, the preference for 'which' becomes apparent (Nevalainen and Raumolin-Brunberg $2003,146)$. The Spanish translation shows present day usage, here and in other occurrences ( 3 in total).

The archaic determiner 'yon' appears twice, the TT showing invariably the same form.

Example 37 (00:02:33)

OV: When yon same star that's westward from the pole

$T T$ : Cuando esa misma estrella al oeste de la polar

The technique applied here has been literal translation. Astrana Marín's translation appears more elaborate: "cuando esa misma estrella que se ve al occidente del polo" (1974, 220). Other Early Modern English forms are present in the original version, which easily take the English speaking audience back to Shakespeare's days. As seen above, the Spanish translation for dubbing does not reflect to the same extent the antiquity of the linguistic choices, often showing contemporary Spanish expressions.

Here follows a table that shows the number of occurrences of the forms analyzed and to what extent the translation for dubbing into Spanish achieves an archaic touch. In percentage terms, it amounts to only $8.7 \%$. 
(5) ederi 27 (2017)

\begin{tabular}{|c|c|c|}
\hline Farewell expressions & No. of occurrences & Translated with archaic touch \\
\hline 'Good night' & 3 & 1 \\
\hline 'Farewell' & 22 & 5 \\
\hline 'Adieu' & 4 & 0 \\
\hline 'God b’wi'ye' & 3 & 3 \\
\hline \multicolumn{3}{|l|}{ G reetings } \\
\hline 'Holla' & 1 & 0 \\
\hline 'How is't' + name? & 4 & 0 \\
\hline $\begin{array}{l}\text { 'How now' + name / } \\
\text { title? }\end{array}$ & 4 & 0 \\
\hline $\begin{array}{l}\text { 'How dost thou' + } \\
\text { name/ title? }\end{array}$ & 2 & 0 \\
\hline ‘How do ye' + title? & 2 & 0 \\
\hline $\begin{array}{l}\text { ‘How does my good } \\
\text { lord?' }\end{array}$ & 2 & 2 \\
\hline ‘What ho' + name! & 1 & 0 \\
\hline 'How fares' + title? & 2 & 0 \\
\hline $\begin{array}{l}\text { 'Good morrow, sweet } \\
\text { lord' }\end{array}$ & 1 & 0 \\
\hline \multicolumn{3}{|l|}{$\begin{array}{l}\text { V arious Early M odern } \\
\text { English linguistic } \\
\text { forms }\end{array}$} \\
\hline 'Ay' & 22 & 3 \\
\hline $\begin{array}{l}\text { Double comparative } \\
\text { forms }\end{array}$ & 2 & 0 \\
\hline Inversion verb-object & 10 & 0 \\
\hline ‘Mine' & 12 & 0 \\
\hline ‘Nay' & 16 & 0 \\
\hline 'Nill' & 1 & 0 \\
\hline 'Perchance' & 5 & 0 \\
\hline 'Royal we' & 36 & 0 \\
\hline
\end{tabular}




\begin{tabular}{|l|l|l|}
\hline 'The which' & 3 & 0 \\
\hline 'Yon/ yonder' & 2 & 0 \\
\hline
\end{tabular}

Table 1. Farewell expressions, greetings and various Early M odern English linguistic forms: number of occurrences in Branagh's Hamlet (ST) and number of archaic forms in the TT.

\section{Concluding remarks}

This paper has sought to provide a thorough analysis of Early Modern English linguistic features present in three of the greatest Shakespeare movies and how they have been transferred in the Spanish translation for dubbing. To that end, a close observation has been carried out of all the forms of address (focusing particularly on second person pronouns and titles) and other archaic forms. A reference to some of the translation techniques applied complements the analysis.

Olivier's $\mathrm{H}$ amlet tries at times to reproduce Elizabethan English, both in the source and target language. That effort, which can also be observed to a lesser degree in the film M uch A do about $\mathrm{N}$ othing, is by no means evenly reflected in the Spanish translation for dubbing.

In Olivier's $\mathrm{H}$ amlet the translation of $\mathrm{y}$-forms as $\mathrm{v}$-forms gives a touch of earlier times, as the translator has chosen outdated forms of Spanish. However, a large number of y-forms (47.2\%) are rendered as t-forms, possibly to show affection from oto the $\mathrm{H}$.

The largest majority of th-forms in $\mathrm{M}$ uch $\mathrm{A}$ do about $\mathrm{N}$ othing are translated as $v$-forms. This most striking fact means that in the Spanish dubbed version there is a clear breach in the linguistic norm, the underlying intention possibly being to take the audience back to the Renaissance with the aid of these pronominal forms, compensating by these means for other Renaissance forms that appear more frequently in the ST but not in the TT. Visual synchrony (and thus lip-sync constraints) as one of the conditions for the good quality of the dubbed product, has not played a part in this decision.

As is the case in Olivier's Hamlet, occasional shifts in treatment are, by the same token, not reflected in the translation for dubbing, so the Spanish audience cannot perceive some revealing changes in mood between $\mathrm{S}$ and $\mathrm{H}$ conveyed by linguistic means. 
Despite the long span of time between Olivier's (1948) and Branagh's version (1996) of $\mathrm{Hamlet}$, there is not a remarkable difference in the treatment of the $y$-forms in the Spanish translation for dubbing.

In the translation of titles the Spanish speaking audience misses a bit of the Italian flavor present in Much Ado's OV through adaptation; this also affects Olivier's $\mathrm{H}$ amlet, because, even though it presents more polite formulae of address in its OV, they are not al ways rendered as such in the target language.

Branagh's Hamlet shows a far greater variety of titles throughout the film which, by and large, have been translated literally for the Spanish audience. However, sometimes one form in Spanish is the translation of several different forms in English (as seen in the case of 'liege', 'majesty' or 'gracious'). By far the most recurrent of all address forms is 'Lord', which may be preceded by honorifics, therefore showing different degrees of formality. The second most frequent title is 'sir'. Both are translated as 'señor'.

The analysis of other Early English forms has shown that the film Much Ado about Nothing presents nine clearly identifiable Renaissance forms. However, they do not find a temporal equivalent in the Spanish choices, which sound contemporary to the audience. In turn, Olivier's $\mathrm{H}$ amlet makes clear, with its seventeen early forms, a slightly greater effort to take the audience back to the Elizabethan period. In spite of that, in $70.5 \%$ cases the Spanish audience does not hear an archaic form.

Branagh's Hamlet presents a far greater number of these early forms, the reason being that the script is based on the Folio and the length of this film is twice that of the previous ones. A part from the titles that may appear, the translation into Spanish does not show early forms.

Lastly, we have centered our attention on a variety of Renaissance forms that appear in greater numbers in Branagh's $\mathrm{H}$ amlet: expressions of farewell, greetings and others: the negative 'nay', the adverb 'perchance', the 'royal we', double comparative constructions, impersonal verbs, contracted verbal forms like 'nill', obsolete pronouns like 'the which', the determiner 'mine' as a variant of 'my', very few of which have found an equivalence in 
early Spanish. Moreover, this absence has not been compensated for linguistically in other parts of the text.

There is no intention to criticize the dubbing team here. At this point, however, one may wonder whether commercial interests may be behind these translation decisions. Olivier's film $\mathrm{H}$ amlet shows a more marked literary word order and lexical choice that may take the audience back to the Renaissance. The successful reception of the film in the 1940s is beyond doubt. It is legitimate, however, to wonder whether this would still hold true. The gap of nearly 50 years between this film version of $\mathrm{H}$ amlet (1948) and M uch A do about N othing (1993) may have been decisive in the linguistic strategy followed, both in the source and target languages, trying in both cases to please the tastes of their contemporary audiences.

The intention to please the audience can be perceived in changes made in the original screenplay, namely 'ye' being replaced with 'you', 'a' being replaced with 'he'; presumably the thought that it would appear too archaic and difficult to understand by the general audience was at the root of those changes. In this same line, it is interesting to point out that even though the three are Shakespeare films, the characters produce contemporary English sounds, even when uttering archaic forms, the pronunciation of which must have been very different in Shakespeare's days.

In Branagh's Hamlet (1996) the translation into Spanish is, as a whole, very literary and takes the audience back to earlier times. Language is a barrier at first and its unusual length makes it unsuitable for a general audience. It is a fact that it was highly acclaimed by many critics and regarded as one of the best Shakespeare film adaptations ever made. However, it was not a box office success. It was conceived as a true "gourmet delicacy" aiming at a limited audience. There may be some truth in the opinion held by some film critics who state that, whether we like it or not, the Shakespeare-related films which have been real box-office successes in Spain are precisely those which have least to do with the writer's style.

Going back to the role of translation, the use of syntactic and lexical embellishments to give a touch of the literary style (Chaume 2012) are found in these films to a greater (Branagh's Hamlet) or lesser extent (Much Ado about Nothing, Olivier's Hamlet). The 
presence of literary terms, a greater use of the subjunctive mood, and a dated word order are frequently used to give the script a touch of the old. Even if the translation for dubbing often falls short of conveying with accuracy the linguistic norms of courtesy, the characters' changes in mood, or the archaic nature of Early Modern English linguistic forms, the audiovisual text compensates for their absence with the support of the interaction of various signifying codes (Mason 2001, 23) that operate simultaneously to produce meaning: the music, the paralinguistic signs (acoustic dimension), the photographic code, types of shots and body language (visual dimension), all intertwine to offer good literary films for different audiences belonging to different times.

\section{References}

Agost, Rosa. 1999. Traducción y doblaje: palabras, voces e imágenes. Barcelona: Ariel.

Algeo, John. 2010. The O rigins and D evelopment of the English Language. $6^{\text {th }}$ ed. Boston: Wadsworth Cengage Learning.

Astrana Marín, Luis, trans. 1974. O bras completas de William Shakespeare. Madrid: Aguilar.

Blake, Norman F. 1996. A H istory of the English Language. London: Macmilan.

Brown, Robert, and Albert Gilman. 1989. "Politeness Theory and Shakespeare's Four Major Tragedies." In Language in Society, edited by Dell Hymes, 159-212. Cambridge: CambridgeUniversity Press.

Burrow, J.A., and T. Turville-Petre. 1992. A Book of M iddle English. Oxford: Blackwell.

Chaume, Frederic. 2012. Audiovisual Translation: Dubbing. Manchester: St. Jerome Publishing.

Corrie, Marilyn. 2006. "Middle English - Dialects and Diversity." In The Oxford History of English, edited by Lynda Mugglestone, 86-119. Oxford: Oxford University Press.

Crystal, David, and Ben Crystal. 2002. Shakespeare's W ords. A Glossary and Language Companion. Penguin Random House. Accessed August 2017. http:/ / www.shakespeareswords.com/ .

Diccionario de la Real Academia de la Lengua Española. http:/ / www.rae.es/ recursos/ diccionarios/ drae.

Fontanella de Weinberg, Ma Beatriz. 2000. "Sistemas pronominales de tratamiento usados en el mundo hispánico." In Gramática descriptiva de la 
lengua española, edited by Violeta Demonde and Ignacio Bosque, 13991425. Madrid: Espasa.

Frago Gracia, Juan A ntonio. 2005. “El tratamiento personal en el Q uijote. Del hecho sociolingüístico al recurso literario." Boletín de la Real Academia Española 85 (291-292): 295-323.

Görlach, Manfred. 1991. Introduction to Early M odern English. Cambridge: Cambridge University Press.

Hatim, Basil, and Ian Mason 1990. Discourse and the Translator. Longman: London.

_-_ . 1997. The Translator as Communicator. London: Routledge.

Hornero Corisco, Ana María. 2006. “Marry, Hang Thee, Brock!: Linguistic Tools for Impoliteness in Shakespeare's Works." In Corpus Linguistics. Applications for the Study of English, edited by Ana Hornero, Ma José Luzón, and Silvia Murillo, 39-59. Bern: Peter Lang.

Hurtado Albir, Amparo. 2004. Traducción y tradu ctología. Madrid: Cátedra.

Mason, Ian. 2001. "Coherence in Subtitling: The Negotiation of Face." In La traducción en los medios audiovisuales, edited by Frederic Chaume and Rosa A gost, 19-31. Castellón de la Plana: Jaume I U niversity.

Molina, Lucía, and Amparo Hurtado. 2002. "Translation Techniques Revisited: A Dynamic and Functional ist A pproach." M eta 47 (4): 498-512.

Moral, Pedro. 2016. “¿Por qué al público ya no le gusta el mejor guionista del mundo?" Cinemanía. El M undo. Accessed September 2016. http:/ / www.cinemania.es/ noticias/ por-que-al-publico-ya-no-le-gustael-mejor-guionista-del-mundo/ .

Nevalainen, Terttu. 2006. "Mapping Change in Tudor English." In The Oxford H istory of English, edited by Lynda Mugglestone, 178-211. Oxford: Oxford University Press.

_-_, and Helena Raumolin-Brunberg. 2003. Historical Sociolinguistics: Language Change in Tudor and Stuart England. London: Longman.

Nord, Christiane. 1997. Translating as a Purposeful Activity: Functionalist A pproaches Explained. Manchester: St. Jerome Publishing.

Palander-Collin, Minna. 1997. "A Medieval Case of Grammaticalization, Methinks." In Grammaticalization at Work: Studies of Long-Term Developments in English, edited by Matti Rissanen, Merja Kytö, and Kirsi Heikkonen, 371-404. Munchen: De Gruyter Mouton.

Wales, Katie. 1996. Personal Pronouns in Present-D ay English. Cambridge: Cambridge University Press.

Weekley, Ernest. 1921. A n Etymological D ictionary of M odern English. London: Murray. 
Filmography

H amlet. Directed by Laurence Olivier. 1948.

$\mathrm{H}$ amlet. Directed by Kenneth Branagh. 1996.

M uch A do about N othing. Directed by Kenneth Branagh. 1993.

How to cite this article:

Hornero Corisco, Ana María. "Translation of temporal dialects in the dubbed versions of Shakespeare films." SED ERI 27 (2017): 47-79.

A uthor's contact: ahornero@unizar.es

Postal address: Dpto. Filología Inglesa y Alemana - Facultad de Filosofía y Letras - C/ Pedro Cerbuna, 12 - 50009 Zaragoza, Spain

Submission: 14/ 11/ $2016 \quad$ A cceptance: 16/ 05/ 2017 


\title{
Rupert G oold's M acbeth (2010): Surveillance society and society of control ${ }^{*}$
}

\author{
Víctor Huertas Martín \\ U niversidad $\mathrm{N}$ acional de Educación a D istancia \\ U niversidad A utónoma de M adrid, Spain
}

\begin{abstract}
This article deals with Rupert Goold's film version of M acbeth (2010). Based on a stage production, this film is set in an unspecified Soviet country. I will analyze Goold's creation of a stage-to-screen hybrid recording framed as a surveillance film. Relying on Michel Foucault's and Gilles Deleuze's works as well as various contributions made by Cultural Materialist and New Historicist critics, I intend to explore the power relations in this surveillance film. I will also examine how the surveillance film conventions deployed by Goold turn the narrative into a meta-filmic event. This allows the viewer to perceive surveillance as part of the subject matter of the story and as inseparable from its narrative structure. Eventually, this will serve to explore how surveillance entirely transforms the filmscape. What begins as a film set in a surveillance society ends up as an environment dominated by a society of control.
\end{abstract}

KEYWORDS: Shakespeare on film; M acbeth; power relations; surveillance society; Foucault; Deleuze.

\section{Macbeth (2010) de Rupert G oold: sociedad de vigilancia y sociedad de control}

RESUMEN: Este artículo trata la versión cinematográfica de $M$ acbeth de Rupert Goold de 2010. Basado en una producción teatral previa, esta película se contextualiza en un país soviético sin especificar. Analizaré la creación a manos de Goold de una grabación híbrida entre el escenario y la pantalla encuadrada como una película de vigilancia. Sirviéndonos de los trabajos de

\section{Macbeth (2010) de Rupert G oold: sociedade da vigilância e sociedade do controlo*}

RESUMO: Este artigo analisa a versão para cinema de M acbeth (2010), por Rupert Goold. Baseado numa produção teatral, este filme tem lugar num estado sovié tico não especificado. Irei analisar a criação, por parte de Goold, de uma gravação híbrida (do palco para o ecrã) enquadrada como um filme de vigilância. Baseando-me no trabalho de Michel Foucault e de Gilles Deleuze assim como

\footnotetext{
* This article is based on a section of the author's PhD entitled "Hybridity in John Wyver's BBC Shakespeare films: A Study of Gregory Doran's M acbeth (2001), H amlet (2009) and Julius Caesar (2012) and Rupert Goold's M acbeth (2010)" (Madrid, UNED 2017).

** Translation into Portuguese by Miguel Ramalhete.
} 
Michel Foucault y Gilles Deleuze, así como de varias contribuciones de los críticos del Materialismo Cultural y del Nuevo Historicismo, pretendo explorar las relaciones de poder en esta película de vigilancia. Por otra parte, examinaré cómo las convenciones cinematográficas de la vigilancia empleadas por Goold convierten la narración en un evento meta-fílmico. Esto permite al espectador percibir la vigilancia como parte del contenido y como parte inseparable de su estructura narrativa. Finalmente, esto servirá para estudiar cómo la vigilancia completamente transforma el espacio de la película. Lo que comienza como una película contextualizada en una sociedad de la vigilancia termina como la recreación de un ambiente dominado por una sociedad de control.

PALABRAS CLAVE: Shakespeare en cine; $M$ acbeth; relaciones de poder; sociedad de vigilancia; Foucault; Deleuze. em várias contribuições feitas por críticos pertencentes ao materialismo cultural e ao novo historicismo, irei explorar as relações de poder neste filme de vigilância. Também irei analisar de que forma as convenções do filme de vigilância mobilizadas por Goold transformam a narrativa num acontecimento meta-fílmico. Isto permite ao espectador percecionar a vigilância como parte do conteúdo da história e como inseparável da sua estrutura narrativa. Finalmente, isto servirá para estudar de que forma a vigilância transforma por completo a paisagem fílmica. Aquilo que começa como um filme situado numa sociedade de vigilância acaba como um ambiente dominado por uma sociedade de controlo.

PALAVRAS-ChAVE: Shakespeare em filme; M acbeth; relações de poder; sociedade de vigilância; Foucault; Deleuze.

\section{Introduction}

“We will annihilate his entire clan, his family! We will mercilessly annihilate everyone who by his actions and thoughts (yes, thoughts too) assails the unity of the socialist state."

(Stalin, qtd. Service 2004, 340)

... Says the tyrant whose specter this film invokes. "Yes, thoughts too." Much attention has been paid to the totalitarian features of Rupert Goold's M acbeth. ${ }^{1}$ Stalin's words echo the commission to massacre the Macduffs after learning that the thane of Fife challenges Macbeth's authority by departing to England (4.2.15054). ${ }^{2}$ Like Stalin's, the Scottish King's tyranny extends to many other

\footnotetext{
${ }^{1}$ This film is a transposition of Goold's stage production at the Minerva Theatre for the Chichester Festival (2007). After being performed in London and New York, the BBC was interested in filming this production and Goold, as well as the whole cast and crew, with John Wyver-head of Illuminations Media-as producer, participated in the process. Eventually, the recording was broadcast on PBS in October 62010.

${ }^{2}$ I am using Braunmuller's edition of M acbeth (2003).
} 
families- "New widows howl, new orphans cry" (4.3.5)—who, as Goold explicitly suggests in several scenes, are decimated under his regime if they "talk of fear" (5.3.37), or if, as Angus' bugging shows in one scene, they speak inappropriate thoughts out loud. ${ }^{3}$ However, neither Macbeth nor Stalin could have anticipated the influence that surveillance societies and societies of control would have in popular fiction and in our daily life in the twenty-first century.

Macbeth's order is, in Goold's "stage-to-screen hybrid" film, transmitted through an intercom connected to an institutional surveillance network. As Goold confirms (Dickson 2016), he was partly inspired by Macbeth's line “There's not a one but in his house| I keep a servant fee'd" (3.4.131-32), alluding to King James' vainglory at keeping an eye on his subjects' privacies (Thomas 2014, 220; Stewart 2003, 76). He also relied on various books on the Gunpowder Plot-e.g. Antonia Fraser's Gunpowder Plot (1996)-and on Shakespeare's possible sympathies for recusants during the Jacobean period (Greenblatt 2004; Hunt 2005; A ckroyd 2006). And he must have been inspired by Gregory Doran's film H amlet (2009) and its display of CCTV cameras within the Danish State. ${ }^{4}$ In more multifarious ways than Doran's, surveillance devices in Goold's film frame the production as a pseudo-Socialist dystopia with an eponymous hero based on the sociopathic Joseph Stalin. ${ }^{5}$ Yet, my intention here is to transcend these alleged parallels between Macbeth and Stalin and explore larger issues connected to surveillance in the production.

My contention is that Goold's M acbeth uses the surveillance film genre to explore power issues in Shakespeare's play-text. These have been reworked in a modernized adaptation which emphasizes the theme of surveillance. Surveillance is not monolithic and exists

\footnotetext{
${ }^{3}$ In this film, after the death of Banquo, Goold inserts the "Stasi Montage." This section consists of a series of short scenes where snapshots of state violence are shown. The police break into a man's room; Alsatian dogs pursue several runaways who try to get across the border; men are led to execution; victims are buried, etc. In the meantime, the Witches-as Servants in Macbeth's household-prepare the table for the coronation banquet.

${ }^{4}$ In an Interview, Wyver explains Goold's interest in the recording of Doran's H amlet (2016). On surveillance in Doran's H amlet, see Lefait (2013-2014).

${ }^{5}$ Martin A mis had al ready noted that Ross' "Alas poor country..." (4.3.166-74) speech can be associated with the "evocation of a terrorized society" under Stalin's rule (2003, 86).
} 
outside the tyrant's control. In fact, surveillance is not simply part of the state apparatus in Scotland but it belongs to the formal structure of the film. A major point of the analysis will be the examination of different types of surveillance in Goold's adaptation. Also, I will examine how the surveillance-based cinematic devices employed by Goold indicate or reflect a transition from a Foucauldian disciplinary society towards a Deleuzian society of control. Whereas both society models work on the premises of surveillance, they operate differently. While the former model bases its power on localized totalitarianism, the latter builds up a more liquid state of vigilance. ${ }^{6}$ My interest in this essay is to examine how Goold's surveillancebased aesthetic choices affect the narrative structure of the film and how these choices help in understanding the larger concerns of surveillance.

$M$ acbeth-whose protagonist has been widely represented on stage as a European dictator (Camati 2005, 341) - can be studied in relation to the deal-making and mutual discrediting through surveillance, plotting, denunciation and delation between rival families taking place in the Jacobean period (Nicholls 1991; Archer 1993; Wills 1995; Greenblatt 2004; Kinney 2008). These plots often blew up in these families' and the crown's faces. King James, himself a watcher and confederate to those who desired Mary Stewart's execution (Schmitt [1956] 2009, 27; Thomas 2014, 150), suffered distress with the public observance his subjects inflicted on him, as Stephen Orgel has pointed out (2011, 29-34). In this regard, Wilson sees the supernatural parade of kings in $M$ acbeth as a court masque possibly including the figure of Mary Stewart recalling James' matricidal treason $(2013,290)$, and therefore as the laying bare of the king's private guilty thoughts. Arguably, the show of kings and the apparition of the murdered queen would unravel popular thoughts and suspicions over the monarch's involvement in the execution of Mary Stewart.

From this it follows that, as surveillance films often demonstrate, state and private spying against political enemies and opponents could be turned against those in power too. In his reworking of the play, Goold's Orwellian nightmare connects the narrative to

\footnotetext{
${ }^{6}$ Experts like David Lyon (2007; 2008) have demonstrated that an apocalyptic analysis of surveillance can be too simplistic and reductive.
} 
contemporary worldwide surveillance exercised "when [people] are thinking, reading, and communicating with others to make up their minds about political and social issues" (Richards 2013, 1935). Communication technologies provide wide access to people's thoughts and ideas through the storing of their readings, their electronic messages, payroll information, bills, and miscellaneous records which allow an approximate reconstruction of their private lives. If Weberians regard state vigilance as a safeguard for our freedoms, many contemporary scandals indicate its frequent unconstitutional, unlawful, and anti-democratic uses (Lyon 2008). Thus, it can be asserted that Goold's film voices contemporary concerns over surveillance and the control derived from such an activity, thus being the first one to develop this dramatic theme in the Scottish Play. Surprisingly, although widely explored in $\mathrm{H}$ amlet films, surveillance has not been thoroughly examined in any $M$ acbeth screen version (except for Welcome M somi's uM abatha, 1970). Arthur F. Kinney, however, has demonstrated that the theme is prominent in Shakespeare's play-text (2008).

\section{Theoretical framework}

Surveillance studies are intimately conjoined with popular fiction and European thought. In this respect, three possible models of surveillance will be identified here. John Michael Archer has called attention to the route to surveillance study opened by Norbert Elias (1993). Elias studies early modern views (and particularly Francis Bacon's) of the monarch's governance as an "angelical power"seeing what is denied to the subjects (Bacon 1999, 249) - moving toward analyses of surveillance seen as a weapon used in the wars between small aristocratic units (1982, 331). However, Goold's vision on surveillance seems to have been filtered through Michel Foucault's more sophisticated analyses of "Panoptic" institutions. Foucault envisages power as a compartmented structure based on Jeremy Bentham's prison model. This analogical space is divided into sections marking out those who present deviant conduct or abnormal behaviors (Foucault [1975] 2012, 166). In an Althusserian analysis of institutions, these localizations of space frame postrevolutionary institutions such as the school, the prison, the family or the hospital as essentially oppressive and determining for the individual's conduct. However, as Foucault indicates, the 
boundaries between the statuses of watcher and watched can shift and power is not possessed by a single entity. Analogously, Gilles Deleuze points to the cultural transition from a post-revolutionary disciplinary society-mostly characterized by institutions-towards the so-called "society of control," where surveillance is in the hands of corporations producing constant tabulations in power relations, undermining all the compactness of institutional apparatuses. Control becomes a less predictable, less institutionalized, more slippery, and depersonalized entangled network which appears to grant more freedom to the citizen but is effectively more controlling through an increase of surveillance mechanisms-i.e. via smartphones- which have widely enlarged the opportunities to accumulate data and information (Deleuze 1990; 1992).

Thus, without our noticing, surveillance becomes part of our daily existence, though still needing means to regulate it. As al ready mentioned, popular fiction has tackled the abuses derived from surveillance to the extent that surveillance studies may have been partly shaped by popular fiction (Lyon 2007). In fact, there seems to be a connection between the origins of film and surveillance practices. As Catherine Zimmer (2015, 6-7) and J. McGregor Wise $(2016,3)$ point out, surveillance caught early filmmakers' imagination: Lumière's W orkers Leaving the Factory and their bosses watching them could be seen as an example of surveillance. However, surveillance in fiction has increasingly focused on the recording of deviant activity. In this regard, as Zimmer observes, filmmakers' inclination to record illicit acts has determined current conceptions of surveillance films $(2015,7)$. Additionally, the selfreflexivity of the surveillance film retrieves the theatrum mundi metaphor for cinema (Lefait 2013; 2013-2014). Thus, surveillance allows the viewer to reflect on the nature of filming itself and then take a flexible position of detachment and/ or identification in relation to the content. In short, not only do we watch the film but, as viewers, are invited to take part in surveillance as well.

McGregor Wise has pointed out that, although each period has developed its "surveillance imaginary" with its own collection of stories and narratives, in the last few years surveillance films have proliferated as a result of the 9/ 11 attacks (2016: 4). In narrative terms, in these films the hero is chased by a manipulating government who, unjustly or not, impeaches him for some crime. 
According to Thomas Y. Levin (2002), surveillance films constitute a perfect fusion of narrative style-with its own tropes and conventions-and content. Such content involves the watching over a victim who eventually turns to be the hero in the narrative. Dietmar Kammerer (2004) -in his analysis of Enemy of the State (1998), M inority Report (2002) and Panic Room (2004)-and, subsequently, McGregor Wise $(2016,10)$ confirm that the surveillance hero is watched but, nevertheless, is able to appropriate surveillance mechanisms to defeat his enemies.

In this production, surveillance alludes to the Otherness configured in a pseudo-Soviet arrangement. Goold's use of such Cold War film tropes within the BBC context can be read as supporting what Pierre Bourdieu has called the imperialist universalization of cultural prejudices (1999); in this case, anticommunist prejudices in anti-communist and Cold War films. ${ }^{7}$ In fact, the Orwellian and totalitarian iconography displayed in this film-mainly in the form of Macbeth's red banner imitating Stalin's effigy - in line with Jacques Derrida's work, seems to conjure up the totalitarian specter of hyper-utopian Socialism. ${ }^{8}$ In my view, rather than trying to explicitly compare Macbeth to a monstrous Soviet dictator, these "residual" Stalinish features-borrowing Raymond Williams' terminology (1977, 121-27) — can be seen as Western visions of the Other (Said 2003: xiii). Goold's use of demonizing Soviet icons, such as the Orwellian Stalinesque Macbeth banner, produces images of the Soviet terror to viewers familiar with the anti-Socialist mythology. ${ }^{9}$ Can we interpret these nostalgiainflected icons in the light of their contemporary relevance? For Boika Sokolova, the film represents "the state of our modern world," though "resited to a communist past" (2013, 169). Against deterministic Althusserian and Baudrillardian views (Althusser [1965] 2005; Baudrillard [1978] 2008), it is certainly possible to read the film against the grain, relying on cultural materialism too, as

\footnotetext{
${ }^{7}$ An entry in one of John Wyver's blogs challenges the film: "What extra this cloning of Hollywood currency has brought to this production? Could winning American audience with little knowledge of the play be one reason?" (Wyver 2010).

${ }^{8}$ As Derrida explains, the Soviet monster has been often used by neoliberalism to present itself as a panacea against the tyrannies of communism ([1995] 2012).

${ }^{9}$ In an "Interview," Goold declares having been inspired by the Kremlin and Cold War films where essentially the ageing Soviet generals fight each other for power (See DVD Extras).
} 
Celestino Deleyto has found in Hollywood partisan cinema (2003, 73). In other words, if these Hollywood clichés denounce Western terrifying visions of its past perceptions of the "Soviet monsters"mostly framed through Cold War films and varied means of propaganda-, the imagery revolving around the Soviet iconography can lead us to think that Goold's film criticizes both Western prejudices and other forms of past totalitarianism. As presented by Goold, the Soviet dystopia which totalizes all the Eastern Block can be read as a tool to undermine such capitalist false myths on socialism denounced by Derrida. If we apply cultural materialist premises, which reject the essentialist and totalizing visions of New Historicism, myths can be criticized and interrogated (Belsey 1992; Dollimore 1989; 1992; Howard 1992; Sinfield 1992; Wilson 1992; 1993; 2013). As Catherine Belsey affirms, meanings of texts are never single and do not unilaterally come out of the interpreters' collective perceptions (1992, 41). Therefore, it can affirmed that this film speaks in the present as well as in the past tense and that the scope of the context encompasses Western as well as Eastern horizons.

\section{The setting}

The main setting in the film is the ballroom at Welbeck Abbey as well as exterior settings chosen for a number of scenes. This room and the other facilities at the Abbey re-create Foucault's "Panopticon." A mongst the many renovations carried out on this twelfth-century building, the Fifth Duke of Portland created multiple tunnels and corridors interwoven through the mansion, ${ }^{10}$ which find their confluence in the ballroom, where the Earl used to hold his social gatherings. ${ }^{11}$ Sam McCurdy, director of photography, managed to get green lighting tones for the ballroom walls, thus evoking Kubrick's The Shinning or hospital-based "slasher" productions. (In fact, the Witches are killers who rip the Bleeding Sergeant's heart out after he is left on a stretcher in a contiguous hospital corridor.) As Goold says, this hospital nightmare represents

\footnotetext{
${ }^{10}$ See N ottinghamshire County Council, "Welbeck A bbey History." Accessed August, 2017. http:/ / www.worksopheritagetrail.org.uk/ resources/ welbeck_abbey_history. pdf.

${ }^{11}$ See "Director's and Producer's Commentaries" in DVD.
} 
what he fears: finding death in the place where comfort should be expected ("Director's and Producer's Commentaries"). Also, the setting plays into the Foucauldian views of disciplinary institutions as places for punishment. ${ }^{12}$

As soon as Macbeth (Patrick Stewart) becomes king, the banner representing his effigy appears embodying the above-mentioned totalitarian Other in the ballroom. This banner underlines the qualities of this surveillance-based regime. In scene 3.1., Banquo (Martin Turner) confronts Macbeth's image and speaks his suspicions towards him out loud. Nevertheless, when he is about to leave the room, he discovers that a buzzing intercom has recorded his whole speech. From that moment on, we know that Macbeth's regime depends on surveillance. The banner materializes how Macbeth keeps an eye on his subjects and the intercom proves that he also hears everything. Likewise, this totalitarian banner underlines Wilson's notion that it is "language which is 'fascist"' as "it compels speech and obliges those who use it to subject themselves to the order it prescribes" (1992, 3). Despite this, Banquo is recorded as he speaks the subversive words not allowed by the regime.

McGregor Wise affirms that surveillance films need to tackle the question of the limits of surveillance in the narrative (2016, 10). However, as already pointed out, Deleuze recognizes power as diffuse and nonlocalized (1987, 52). In this light, imitating several Shakespeare films that work on the oscillations between the languages of theater and film (Davies 1991), Goold's filmscape centrifugally stretches an apparently unlimited surveillance out without totally leaving its center: the ballroom. The cables interconnecting the rooms reach the Abbey cloister, where the Macbeths discuss what to do with the daggers (2.2). They also reach the kitchen, hospital facilities, the corridors, the mansion, and, eventually, the Trans-Siberian Express.

\footnotetext{
12 In dialogue with D. Cooper, M.-O. Faye, J.-P. Faye, and M. Zecca, Foucault compares the hospital with an institution that repairs the disorders produced by society. In this light, as in the Soviet Union, the intensified pairing of the medical profession with the coercive police shapes the consolidation of a fascist section of hyper-normal citizens versus the abnormal society members (2012: 126-27, 142).
} 


\section{Surveillance between different factions}

Surveillance-based power in this film is shifty and complex. As Dollimore indicates, power is non-monolithic (1984). Likewise, in this film, surveillance and, consequently, power, go hand in hand. The first overt allusion to technology-based surveillance takes place when Macduff yells through an intercom from Macbeth's kitchen announcing Duncan's death (2.3.67-74). The institutional corridors at Welbeck Abbey are wired; in fact, the state equipment has existed long before Macbeth: it predates his crowning. Yet, these facilities do not necessarily guarantee people's securities but only ensure that certain factions maintain their hegemonic power.

Thus, in this nightmarish world, characters mutually spy on each other. And in fact, Macbeth is spied on too, although initially, the evidence gathered does not suffice to overthrow him. After the discovery of Duncan's death, and subsequent to Macduff's summoning of Duncan's thanes to Macbeth's kitchen, Goold quotes Welles' filming of the scene by making Lennox (Mark Rawlings) and Macbeth exchange glances of complicity after the bloody daggers are produced. ${ }^{13}$ Also Banquo, suspicious of Lady Macbeth's fainting, conspiratorially mutters to Macduff (Michael Feast): "Look to the lady" (2.3.118). Later, being "caught-in-theact" through the intercom, Banquo is heard as he speaks against the tyrant. Although he has the moral grounds to accuse Macbeth, he lacks the political alliances for such an action.

Meanwhile, surveillance forges new alliances. After 2.3, the Porter (Christopher Patrick Nolan) takes over some of the Old Man's lines (2.4) at the Abbey courtyard. While smoking, he nonchalantly converses with Ross (Tim Treloar) about the assassination and observes Macduff's family when they leave in their car. At the same time, a long shot shows an outsider's viewpoint watching them all through the bars of the mansion gate. Unquestionably, surveillance exists outside Macbeth's rule. This means that Macbeth's spies are not the only ones who watch. Furthermore, at their meeting, Malcom (Scott Handy) and Macduff see photos of the people who suffer Macbeth's tyranny in a landscape recalling of the Gulag. These images function as triggers for the rebellion against the tyrant.

${ }^{13}$ In Welles' version, the Holy Father (Alan Napier), shown in extreme close-up, scrutinizes Macbeth after he kills the grooms. 
Therefore, even Macduff is partly a sharer in the power granted by evidence to build up a legitimate case against the dictator. In fact, in a later scene, called the "Stasi Montage" by Goold (see footnote 3), a series of state crimes committed by Macbeth are shown in snapshots which make the viewer complicit with the diegetic surveillance activity. In fact, the Porter is shown watching military parades on television in a manner that invites the viewer to partake in surveillance activity.

As for Ross, Lennox, the Porter, Angus (Bill Nash) and the First Murderer (Hywel John), they all collect information for and against Macbeth. While Angus bugs people's homes to get information, the Porter spies for Macbeth, and Ross gathers files on Macduff. From the beginning of the film, Ross carries files on Norway's defeat and Cawdor's treason. Lennox collects files on those who want to oppose Macbeth. However, he also collects files on Macbeth himself. As he interrogates Ross, he is deliberately ambiguous in his explanation of Duncan's death, Malcom's imputation and Banquo's murder. Before this, during Banquo's killing on the train, the First Murderer knows that Lennox has been sent to oversee the operation and then he witnesses how Lennox shoots the Second Murderer after a short dispute. The state bureaucrats are inclined to accept any such inhumanity as mere administrative procedure. But whereas the First Murderer, Angus and Ross are swifter in turning against Macbeth, Lennox and the Porter embrace real politik and willingly collaborate with him. Ironically, Lennox's files on Macbeth ("I have a file| Of all the gentry..." 5.2.8-9) are decisive to buy him a passage to join Malcom's rebellion. ${ }^{14}$ Thus, no matter how slow many have been in changing sides, information is a safe-conduct to make an alliance with those in power. Thus, loyalty is less important than information.

\section{Sons watching parents}

Foucault's analysis of power also regards the family as a major disciplinary institution. Yet, Macbeth's regime works against the stability the family is expected to provide. As Vasily Grossman says,

\footnotetext{
${ }^{14}$ In this film, the Second Murderer (Christopher Knott) is killed by Lennox after the assassination of Banquo. The First Murderer survives and becomes a member of Macbeth's secret police.
} 
"in one hut there would be something like a war. Everyone would keep close watch over everyone else [...]. The wife turned against her husband and the husband against his wife. The mother hated the children" (quoted in Conquest 1986, 256). To some extent, this passage seems to have determined Goold's vision of the Macduff family's division into different perspectives and responses to treason, some of them hostile to the mother. Lady Macduff (Suzanne Burden) tries to keep her children entertained with a pretense of normalcy while potential dangers approach. After her husband disappears, she attends one of the military parades and her worrying looks show that in the previous scenes she was keeping up appearances in the male-dominated ambience of Macbeth's kitchen.

Because of the bitter battle of wits with her bookish daughter (Lillian Dummer) and the milder conversation with her son (Hugo Docking), Macduff's wife sees her smile turned into a grin. Like Roald Dahl's Matilda, Macduff's daughter reads books and is critical of what her mother thinks and does. She asks her, mockingly: "Nay, how will you do for a husband?" (4.2.39). But the sharpest accusation comes when she addresses her scathing criticism of her mother: "Then you'll buy 'em to sell again" (4.2.41). How is her mother so naive as to sell their father out and uphold this orchestrated farce about his treachery? As opposed to this confrontational attitude, Macduff's son's approach is more sensitive and kinder as he prefers to plainly ask direct questions. ${ }^{15}$ Here Goold introduces a dramatic statement, from which it follows that perhaps the children, even if not completely understanding the whole picture, are certain about the many flaws that both the regime and the official history of their father's treachery present. For these children, that their father is a traitor is simply a wasteful thought. Therefore, they interrogate their mother's act.

In this scene, Goold alludes to the many incidents related to children denouncing their parents during the Stalinist era. Amis' Koba the D read, which, as indicated by Stewart (see "Theater Talk" 2008), was one of the sources of inspiration for Macbeth's characterization, refers to how "children who denounced their parents became national figures, hymned in verse and song" (2003,

${ }^{15}$ Goold distributes Young Macduff's original lines between the son and the daughter. A third younger daughter, a silent part, helps further develop Goold's study of the family as an institution tarnished by Macbeth's subversive regime. 
154). Previously, he mentions that "some parents killed their children. And other parents ate their children" (141). Seeing how the Macduff family is treated in this film from this angle, can we say that this a situation in which the family is about to face such a serious split? The murder squad does not give us time to find out. In any case, Macduff's daughter's questions are fissures in this disciplinary state. She sees the flaws of a system that does not use surveillance to capture criminals but to punish dissenting voices.

However, even if this fictionalization of a family split is rather timorous, Goold works on this idea in the "Stasi montage." In this section, one of the families scrutinized by Lennox's secret service is assaulted at home. As mentioned above, a little boy talks to Lennox and directly points at his mother. As the mother sees the officers coming, she starts running away, leaving her child unprotected in Lennox's hands. The fact that the child does not intentionally accuse her does not alter the cruelty of the situation nor does it change the fact that Macbeth's surveillance state is a threat to the institution of the family. In this respect, Macbeth's surveillance is aggressive against the conservative disciplinary and regulative principles embodied by such an institution as part of the larger social framew ork. ${ }^{16}$

\section{6. "Banquo and Macbeth all hail" (1.3.67)}

The first man in this production who, with some sarcasm, seems to be startled at Macbeth's kingship is Banquo. As al ready mentioned, Banquo does not shy away from appearing to be a threat to Macbeth's totalitarian regime. Macbeth and Banquo's mutual watch starts in the ballroom-scene 1.3 in the film-, where Banquo becomes a watcher as he starts keeping an eye on everything Macbeth does and thinks, particularly as he whispers to a mannequin dressed in a military jacket and reanimated by the Witches with a pumping heart-the Bl eeding Sergeant's heart. When the King embraces him, Banquo makes sure to let Macbeth see how

\footnotetext{
${ }^{16}$ In this production, Lady Macbeth (Kate Fleetwood) keeps a little shoe, a memento mori of her dead child. Yet, this dead child is from another marriage, as Patrick Stewart points out in an interview (see CD). Instead of children, the Macbeths keep an unusually personal relationship with a Servant (Oliver Birch), who is slightly retarded.
} 
little he matters for the elites of the kingdom. ${ }^{17}$ Is the peasant Macbeth perhaps thinking of high-flying with his betters? Later, in scene 2.1, a canted frame shows Macbeth confronted by Banquo in the kitchen right after the protagonist, sitting down near Fleance, tries to suggest that Banquo should be his accomplice. Banquo towers above his rival. Subsequently, he asks Fleance to quickly come back to him and threateningly makes clear to Macbeth that he will not do anything dishonorable. As mentioned above, he confides his suspicions on Lady Macbeth's fainting to Macduff and then openly addresses Macbeth while stating his suspicions of "treasonous malice" (2.3.125). Very likely, with this, Banquo has just signed his own death warrant. A reaction shot shows Stewart's resentful visage, which proves that very shortly he will take action against a possibly subversive Banquo.

After Banquo's speech is registered through the intercom in scene 3.1, David Tennant-as Hamlet- takes away one of the CCTV cameras from the wall in an outburst of rage, and Banquo furiously removes the intercom from the wall. Subsequently, his encounter with Macbeth and Lady Macbeth takes place at the courtyard of the mansion. Banquo and Fleance (Bertie Gilbert) are caught, in their travelling clothes and suitcases in hand, by a haunting party as they try to leave the country. In that guise, Banquo's promise of return for the banquet does not seem credible at all. As for Macbeth, on horse, he boisterously and even threateningly urges Banquo not to miss the feast. $\mathrm{H}$ is theatrical stature increases as he deduces that Banquo is probably trying to gather foreign alliances to turn against him, which gives him a pretext to eliminate his rival.

\section{D iegeticized surveillant omniscience}

As already suggested, surveillance blurs the boundaries between form and content in the filmic narrative. As Levin indicates in his analysis of Ford Coppola's The Conversation (1974), surveillance films have the capacity to "move away from a thematic to a structural engagement" in the film narrative $(2002,582)$. When the protagonist tries to find out the surveillance mechanisms in his apartment, the

\footnotetext{
${ }^{17}$ In this film production, it is obvious that-like Stalin-Macbeth comes from the rank-and-file and his political status is inferior to those of his fellow generals. This is confirmed in an Interview with Patrick Stewart in the DVD (2010).
} 
viewer discovers that the locus of surveillance "resides in a space that is epistemologically unavailable to [Gene Hackman] within the diegesis" and, thus, surveillance becomes "the condition of the narration itself" (583). Arguably, this "diegeticized surveillant omniscience" will be frequent in CCTV-based surveillance films of the 1990s onwards.

It can be rightfully stated that a similar effect takes place in Goold's M acbeth. Besides the abovementioned anonymous vigilant presence at the courtyard, there are other instances of surveillant omniscience, such as the "Stasi Montage," where several bits of state violence and documentary footage with military parades are shown while the servants prepare the table for the banquet scene. Also, some long shots feature Macbeth and Lady Macbeth covered in blood in a wide cloister corridor after the murder of Duncan. At that point, they seem to be under vigilance by some unseen mechanism. Since the Witches are the ones who stage-manage this institutional and nightmarish plot, it is not difficult to relate this omniscient surveillance to the supernatural. As Terry Eagleton states, the Witches "figure as the 'unconscious' of the drama, regarded as threatening but which tends to aggressively return, not so much subverting the binary opposition of chaos and order as deconstructing it" (1986, 2-3). Their presence de-regulates the already flabby but essentially hyper-rational, totalitarian and bureaucratic organization of surveillance in Scotland.

In fact, their surveillance seems to take place mostly around the ballroom, which preserves all the make-believe of theater. As al ready suggested, this area constitutes a center of surveillance in the film. Firstly, the Witches and Banquo see and watch over Macbeth's murderous thoughts. Yet, Banquo's watch backfires on him when he is caught by Macbeth's intercom as he challengingly looks at the tyrant's banner. Although Macbeth has been discovered by Banquo - "and I fear| Thou played'st most foully for't" (3.1.2-3) - , this does not at all discourage him in his murderous rule. However, it is at the ballroom that Banquo's Ghost returns as bloody witness to Macbeth's treacherous assassination. Eventually, Macbeth's last encounter with the Witches presents how the source of filmic integration between thematic and formal surveillance is articulated.

The Witches' powers depend on their technological control, no matter how rusty and dated this technology may seem to be. In 
scene 4.1, the parade of Kings is presented through several superimposed takes of Fleance entering the room. This editing turns the Witches into film auteurs of sorts. Mimicking a rudimentary digital reality, the visions line up in front of Macbeth. If the Witches' powers are connected to technology, it shouldn't be a surprise that they extend their powers to the audiovisual potentialities of an editing room. The abovementioned court masque thus becomes a surveillance feast where Macbeth's thoughts of Fleance and "Banquo's issue" are visually arranged. The Witches do not only figure the subconscious, as Eagleton remarks. They are also capable of shaping it in filmic forms. Macbeth's lack of understanding of where this omniscient level of surveillance comes from evinces that he is under surveillance too. Thus, the theatrum mundi metaphor is recovered in the production as the hero sees himself as part of a visual narrative framing the whole event. If Macbeth can extend his command of the Scottish institutional apparatus through symbols and images of fascism, the indefiniteness and the deregulated strength of the Witches' surveillance suffices to make Macbeth's communist dystopia give way to the liquidity of more Baudrillardian simulacra in the form of scraps of filmic narrative and a disorganized amalgamation of surveillance footage replacing this decayed horror state.

An additional proof that surveillance based on visual fabrics exists outside Macbeth's rule and within the filmic structure is the last sequence, in which different settings are shown as different levels in a video game. Thus, the viewer is invited to patrol over the kitchen, the corridors, the hospital facilities, the campaign hospital, the dark tunnels of the abbey, and, finally, the lift, where Macbeth and Lady Macbeth take their last journey. Surveillance follows its own channels, aligned to the neoliberal spiral of liquidity and decentralization, which ends up eliminating all sense of consistency and real freedom. In fact, as suggested, these last shots seem to reframe the narrative as a video game, bound to repeat its narrative with very few possibilities for the player except for those programmed by an unknown creative community of designers and programmers. In the "Director's and Producer's Commentaries," Goold, in fact, alludes to these last shots as the patrolling at the final stages of such video game. This reference embodies the Deleuzian paradox that, whereas the coordinates of surveillance and power appear as diffuse and untraceable, yet it situates the watched within 
the very narrow confines of an interactive narrative that allows only as many options as the programmers deem acceptable. ${ }^{18}$ The viewer is made complicit in this effect as, like the Porter watching the military parades on television, he watches the different scenarios of this massive scrutinized matrix, perhaps unaware that he is one more part in it.

\section{Conclusion}

The surveillance frame used by Goold modifies the traditional modes in which British TV has recorded Shakespeare stage productions. Although this film is theatrical in its homage to an original stage-based rationale, it is unusually-for British recorded theater-influenced by a plethora of Hollywood film conventions. The fact that the film, as a Shakespeare adaptation, still constitutes a feast for the ear as well as a visual delight clarifies the complex stance of this hybrid narrative. Therefore, conventions borrowed from the surveillance film struggle with the BBC's traditional house rules of studio drama, television film or live recording.

Goold's affiliation to Hollywood generic conventions seem to align him with narratives which are critical of the dangerous cons derived from surveillance malpractice. Surveillance films and series of the last two decades confirm Deleuze's belief that postrevolutionary surveillance disciplinary values are being replaced by values of the society of control, where power consists of random shifts and tabulations that resemble the dynamics of the game show rather than the hyper-rational dynamics of totalitarian civil rule. Parallel to this transition from one power system to another, Goold's film reflects it as it shows an aural disciplinary world which also makes use of reports and documents. This disciplinary world is mostly in the hands of localized subjects and civil servants. Progressively, this primitive system gives way to a more visual tyranny based on incomprehensible images edited by unreachable entities.

This liquidity, which does not permit the viewer to rationalize how power is structured in this society of control, invokes the

\footnotetext{
${ }^{18}$ In fact, Goold's self-proclaimed intention here is to pose the question that perhaps all this will happen again (See "Director's and Producer's Commentaries").
} 
intertextual complexity of the production. Despite Sokolova's recognition of elements alluding to our contemporary world, the pseudo-Soviet context of the film is still too general. All references to the Soviet totalitarian dystopia may amount to no more than scraps and shards of Western paranoid visions on Marxist failed utopias. However, the subconscious insights provided by omniscient surveillance show the scratches and holes of this Foucauldian nightmarish construction. A more malleable, less predictable, less organized and much less localized type of surveillance seems to run in parallel with the growth of defamiliarizing, cutting and editing in the Witches' scenes. Following an opposite route to the Lacanian and Freudian analogies on language and growth, the hyper-rational and institutionalized analogical system of discipline and surveillance in Macbeth's world has given way to a much more semiotic and infantile shapeless succession of images, which peep through the little fissures in the shield of the regime. As Wilson suggests, capitalism does not simply involve economic change but also linguistic change (1992, 2). Thus, the chaotic language of omniscient surveillance breaks all boundaries pinpointed in the Foucauldian space. As Michael Hardt and Antonio Negri suggest, the transcending of national boundaries favors the development of massively entangled networks of control (2000). In this light, state control in the film gives way to an undefined unreal macro-system of simulacra, reediting, repeated images, unintentional and disorganized snapshots. Yet, this does not mean that control has ceased.

It is no accident that the communist Derridean Ghosts in the film are defeated by marginal figures like the Witches and other female characters. To some extent, Macduff's daughter's scrutinizing on her mother's hypocritical stance for the regime seems to point at the crumbling system of discipline and punishment. Whereas the visions that pervade Goold's disciplinary state fulfill the Western nightmares and clichés stigmatizing the Eastern Other, the feminine subversive element, embodied in the Witches and Lady Macbeth, foregrounds the marginal, the creative, and the bloody altogether. Nevertheless, female interrogation of totalitarianism does not truly lead to encouraging or positive glimpses of a Utopian tomorrow beyond Macbeth's downfall, except for Macduff's daughter's critical gaze. 
Such downfall is shown when Malcom holds the tyrant's bloody head, a mutilated body part working as metonymy of the fall of the whole surveillance state. He has managed to defeat Macbeth because he has learned to control the tyrant's iconographic language. But the new government does not know that Macbeth's surveillance regime is subject to a larger regime of control over people's inner fears and thoughts. Rather than eradicating the Stalinist threat quoted in the introduction, a new liquid surveillance will unravel, manipulate and, if necessary, edit and reconfigure these thoughts in the form of montages of images and film scraps. In other words, Goold's clearly pessimistic vision presents an essentialist myth of socialist tyranny intermingling with another-perhaps also essentialist-myth of a liquid and undefined regime of far-reaching control. Is this society of control in the Witches' hands? Is it in the filmic structure itself? As in Coppola's The Conversation (1974), Goold succeeds in not providing clear answers to this problem posed by control societies.

\section{References}

A ckroyd, Peter. 2006. Shakespeare (The Biography). London: Vintage.

Althusser, Louis. (1965) 2005. “Ideología y aparatos ideológicos del Estado (notas para una investigación)." In La filosofía como arma en la revolución, translated by Oscar Molina, 102-28. M éxico: Siglo XXI.

A mis, Martin. 2003. Koba the Dread: Laughter and the Twenty Million. New York: Vintage International.

Archer, John Michael. 1993. Sovereignty and Intelligence (Spying and Court in the English Renaissance). Stanford: Stanford University Press

Bacon, Francis. 1999. "New Atlantis." In Francis Bacon (Selected Philosophical Works), edited by Rosemary Sargent, 239-68. Indianapolis: Hackett Publishing Company.

Baudrillard, Jean. (1978) 2008. Cultura y simulacro, translated by Antoni Vicens and Pedro Rovira. Barcelona: Editorial Kairós.

Belsey, Catherine. 1992. "Literature, History, Politics." In N ew H istoricism and Renaissance D rama, edited by Richard Wilson and Richard Dutton, 33-44. London and New York: Longman.

Bourdieu, Pierre. 1999. Intelectuales, política y poder, translated by Alicia B. Gutiérrez. Buenos Aires: Eudeba Editorial Universitaria.

Conquest, Robert. 1986. The Harvest of Sorrow: Soviet Collectivization and the Terror-Famine. New York and Oxford: Oxford University Press. 
Cooper, David, Marie-Odile Faye, Jean-Pierre Faye, Michel Foucault, and Marine Zecca. 2012. “Encierro, psiquiatría, prisión.” In U n diálogo sobre el poder y otras conversaciones, edited by Michel Foucault and translated by Miguel Morey, 124-68. Madrid: Alianza Editorial.

Davies, Anthony. (1989) 1991. Filming Shakespeare's Plays (The A daptations of Laurence Olivier, Orson Welles, Peter Brook and Akira Kurosawa). Cambridge: Cambridge University Press.

Deleuze, Gilles. 1987. Foucault, translated by José Vázquez Pérez. Barcelona: Editorial Paidós.

_-_. 1990. "Control and Becoming: Gilles Deleuze in Conversation with Antonio Negri." Translated by Martin Joughin. Futur Anterieur 1. Accessed September 2017.

http:/ / www.uib.no/ sites/ w3.uib.no/ files/ attachments/ 6._deleuzecontrol_and_becoming.pdf.

_-_. 1992. "Postscript on the Societies of Control." 0 ctober 59: 3-7.

Deleyto, Celestino. 2003. Ángeles y demonios. Representación e ideología en el cine contemporáneo de H ollywood. Barcelona: Ediciones Paidós.

Derrida, Jacques. (1995) 2012. Espectros de M arx: el estado de la deuda, el trabajo del duelo y la nueva Internacional. Translated by José Miguel Alarcón and Cristina de Peretti. Madrid: Editorial Trotta.

Dickson, Andrew. 2016. "Rupert Goold: 'It Was Pretty Intense, Living with My Lady Macbeth'." The Guardian, July 17, 2016. A ccessed September 2017. https:/ / www.theguardian.com/ stage/ 2016/ jul/ 17/ rupert-gooldmacbeth-shakespeare.

Dollimore, Jonathan. 1989. Radical Tragedy: Religion, I deology and Power in the D rama of Shakespeare and $\mathrm{H}$ is Contemporaries. Hemel Hempstead: Prentice $\mathrm{H}$ all, Harvester Wheatsheaf.

_-_. 1992. "Shakespeare, Cultural Materialism and the New Historicism." In N ew Historicism and Renaissance Drama, edited by Richard Wilson and Richard Dutton, 45-56. London and N ew York: Longman.

Eagleton, Terry. 1986. William Shakespeare. Rereading Literature series. Oxford: Blackwell.

Elias, Norbert. 1982. The Civilizing Process. Vol. 2: Power and Civility. Translated by Edmund Jephcott. New York: Pantheon.

Foucault, Michael. (1975) 2012. Vigilar y castigar: el nacimiento de la prisión. Translated by Aurelio Garzón del Camino. Madrid: Editorial Biblioteca Nueva.

Fraser, Antonia. 1996. The Gunpowder Plot: Terror and Faith in 1605. London: Orion House. 
Greenblatt, Stephen. 1994. "Invisible Bullets: Renaissance Authority and Its Subversion, Henry IV and Henry V." In Political Shakespeare: Essays in Cultural $M$ aterialism, edited by Jonathan Dollimore and Alan Sinfield, 1847. Manchester: Manchester University Press.

- - - 2004. W ill in the W orld: How Shakespeare Became Shakespeare. New York and London: W. W. Norton \& Company.

Grossman, Vasily. Forever Flowing. Translated by Thomas P. Whitney. New York: Possev-Verlag, 1972.

H amlet. 2009. Directed by Gregory Doran. Illuminations Media and BBC. DVD.

Hardt, Michael, and Antonio Negri. 2000. Empire. London: Harvard University Press.

Howard, Jean E. 1992. "The New Historicism in Renaissance Studies." In $\mathrm{N}$ ew Historicism and Renaissance Drama, edited by Richard Wilson and Richard Dutton, 19-32. London and New York: Longman.

Hunt, Maurice. 2005. "Reformation/ Counter-Reformation M acbeth." English Studies 86 (5): 379-98.

Kammerer, Dietmar. 2004. "Video Surveillance in Hollywood Movies." Surveillance \& Society (CCTV Special) 2 (2/3): 464-73.

Kinney, Arthur F. 2008. “Macbeth's Knowledge." In Shakespeare Survey. V ol. 57: $M$ acbeth and Its Afterlife, edited by Peter Holland, 11-26. Cambridge: Cambridge University Press.

Lefait, Sébastien. 2013. Surveillance on Screen: M onitoring Film and Television Programs. Lanham: Scarecrow Press.

-_- 2013-2014. “'This same strict and most observant watch' (1.1.71): Gregory Doran's Hamlet as Surveillance Adaptation." Borrowers and Lenders: The Journal of Shakespeare and Appropriation 8 (2). Accessed September 2017. http:/ / www.borrowers.uga.edu/ 1072/ pdf.

Levin, Thomas Y. 2002. "Rhetoric of the Temporal Index: Surveillant Narration and the Cinema of 'Real Time'." In CTRL [Space]: Rhetorics of Surveillance from Bentham to Big Brother, edited by Thomas Y. Levin et al., 578-93. Cambridge, Mass.: MIT Press.

Lyon, David. 2007. Surveillance Studies. A n O verview. Cambridge: Polity.

_-_. 2008. "Surveillance Society." Paper presented at the Festival del Diritto, Piacenza, Italy, September 28, 2008.

M acbeth. 1948. Directed by Orson Welles. Mercury Productions. DVD.

M acbeth. 2010. Directed by Rupert Goold. Illuminations Media and BBC. DVD. 
McGregor Wise, J. 2016. Surveillance and Film. New York and London: Bloomsbury A cademic.

Nicholls, Mark. 1991. Investigating Gunpowder Plot. Manchester: Manchester University Press.

Orgel, Stephen. 2011. Spectacular Performances: Essays on Theatre, Imagery, Books and Selves in Early Modern England. Manchester: Manchester University Press.

Richards, Neil M. 2013. "The Dangers of Surveillance." Harvard Law Review March 25: 1934-1965.

Said, Edward. 2003. O rientalism. London: Penguin Classics.

Schmitt, Carl. (1956) 2009. Hamlet or H ecuba: The Intrusion of the Time into the Play. Translated by David Pan and Jennifer Rust. N ew York: Telos Press.

Service, Robert. 2004. Stalin: A Biography. London: Macmillan.

Shakespeare, William. 2003. M acbeth. Edited by A. R. Braunmuller. Cambridge: Cambridge University Press.

Sinfield, Alan. 1992. "M acbeth: History, Ideology and Intellectuals." In N ew $\mathrm{H}$ istoricism and Renaissance D rama, edited by Richard Wilson and Richard Dutton, 167-80. London and New York: Longman.

Sokolova, Boika. 2013. “'Horrible Imaginings': Rupert Goold's Film Adaptation, a M acbeth for the Twenty-First Century." In Shakespeare on Screen: M acbeth, edited by Sarah Hatchuel, Nathalie-Guerrin, and Victoria Bladen, 149-69. Mont-Saint-Aignan: Presses Universitaires de Rouen et du Havre.

Stegh Camati, Anna. 2005. "Textual Appropriation: Totalitarian Violence in Shakespeare's M acbeth and Tom Stoppard's Cahoot's M acbeth." IIha do D esterro 49: 339-67.

Stewart, Alan. 2003. The Cradle King: The Life of James VI and I, the First $M$ onarch of a U nited G reat Britain. New York: St. Martin's Press.

“Theater Talk: Patrick Stewart, Rupert Goold on Macbeth." A pril 2008, PBS. Video, 25:08. https:/ / www.youtub.com/ watch?v=DMyfSQQamIA .

Thomas, Alfred. 2014. Shakespeare, D issent and the Cold War. Basingstoke: Palgrave Macmillan.

Williams, Raymond. 1977. M arxism and Literature. Oxford: Oxford University Press.

Wills, Garry. 1995. Witches and Jesuits. Oxford: Oxford University Press.

Wilson, Richard. 1992. "Introduction: Historicising New Historicism." In New Historicism and Renaissance Drama, edited by Richard Wilson and Richard Dutton, 1-18. London and New York: Longman. 
1993. Will Power: Essays on Shakespearean Authority. Detroit: Wayne State University Press.

_- - 2013. Free W ill: A rt and Power on Shakespeare's Stage. Manchester and New York: Manchester University Press.

Wyver, John. 2010. "Macbeth with Sir Patrick Stewart: The Scottish Play from Stage to TV." Bbctvblog, December 9, 2010. Accessed September, 2017. http:/ / www.bbc.co.uk/ blogs/ tv/ 2010/ 12/ macbeth-patrickstewart-tv.shtml.

_-_. 2016. Interview with author on June 21, 2016. Unpublished.

Zimmer, Catherine. 2015. Surveillance Cinema. New York and London: New York University Press.

How to cite this article:

Huertas Martín, Víctor. “Rupert Goold's M acbeth (2010): Surveillance society and society of control." SED ERI 27 (2017): 81-103.

A uthor's contact: victor.huertasm@uam.es

Postal address: Dpto. Filología Inglesa - Facultad de Filosofía y Letras - Universidad Autónoma de Madrid - Campus de Cantoblanco - 28049 Madrid, Spain 


\title{
Shakespeare our contemporary in 2016: M argaret Atwood's rewriting of The Tempest in Hag-Seed
}

\author{
Sofía Muñoz-Valdivieso \\ U niversidad de M álaga, Spain
}

\begin{abstract}
Margaret Atwood's novel $\mathrm{H}$ ag-Seed (2016) is a retelling of The Tempest that transfers the actions from the magic island of the original play to presentday Canada: the avant-garde artistic director of a Shakespearean Festival is ousted from his job by his more world-savvy deputy, lives in isolation for twelve years and plots his revenge, which will involve a staging of The Tempest at the local prison where he has been teaching for some time as $\mathrm{Mr}$ Duke. $\mathrm{H}$ ag-Seed is part of a larger project of fictional retellings of the Bard's plays conceived by Hogarth Press for the commemoration of the $400^{\text {th }}$ anniversary of his death, a moment when Shakespeare's cultural capital seems to be circulating more energetically than ever. The present article analyses $\mathrm{H}$ ag-Seed as a neo-Shakespearean novel that is original in the double sense of the term that A twood's teacher N orthrop Frye so frequently remarked: imaginative, innovative, and inventive but also true to its fountain and origins.
\end{abstract}

KEYwords: Shakespeare; The Tempest; Margaret Atwood; Hag-Seed; neoShakespearean novel; cultural capital.

Shakespeare, contemporáneo nuestro en 2016: $M$ argaret A twood reescribe The Tempesten $\mathrm{Hag}$ Seed

RESUMEN: La novela Hag-Seed (2016) de Margaret Atwood reescribe la pieza teatral de William Shakespeare La Tempestad y traslada las acciones de la isla mágica del original a Canadá en nuestros días: un director de teatro experimental pierde su trabajo al frente de un importante festival Shakespeariano por las maquinaciones de su ambicioso subdirector, vive en soledad durante doce años y planifica su venganza, para la que usará una versión teatral de La Tempestad con los internos de una prisión local en la
Shakespeare, nosso contemporâneo em 2016: a reescrita de The Tempestem $\mathrm{Hag}$ Seed, de M argaret A twood*

RESUMO: O romance Hag-Seed (2016), de Margaret Atwood, é um reconto de The Tempest que transfere as ações que têm lugar na ilha mágica da peça original para o Canadá da atualidade: o vanguardista diretor artístico de um Festival de Shakespeare é expulso do seu trabalho pelo seu substituto, mais sabedor de como o mundo funciona, vive isolado durante doze anos e planeia a sua vingança, que irá envolver uma encenação de The Tempest na prisão local em que tem vindo a ensinar há algum tempo sob

\footnotetext{
*Translation into Portuguese by Miguel Ramalhete.
} 
que lleva varios años trabajando como el profesor de literatura Mr Duke. H ag-Seed es parte de un proyecto de novelas encargadas por la editorial Hogarth Press que reescriben piezas teatrales del Bardo para la celebración del 400 aniversario de su muerte en 2016, un momento en el que el capital cultural de Shakespeare parece circular con particular intensidad. EI artículo analiza $\mathrm{H}$ ag-Seed como una novela neo-Shakespeariana original en el doble sentido del término que con frecuencia resaltaba el profesor de Margaret Atwood, Northrop Frye: ingeniosa, imaginativa e innovadora pero también fiel a sus fuentes y orígenes.

PALABRAS CLAVE: Shakespeare; The Tempest; Margaret Atwood; Hag-Seed; novela neo-Shakespeariana; capital cultural. o nome de Mr Duke. Hag-Seed faz parte de um projeto maior de recontos ficcionais das peças do Bardo concebido pela Hogarth Press para comemorar os 400 anos da sua morte, um momento em que o capital cultural de Shakespeare parece estar a circular com mais energia do que nunca. Este artigo analisa $\mathrm{H}$ ag-Seed enquanto romance neo-shakespeariano que é original de acordo com o duplo sentido do termo tão frequentemente notado pelo professor de Atwood, Northrop Frye: imaginativo, inovador e inventivo, mas também fiel à sua fonte e às suas origens.

PALAVRAS-ChAVE: Shakespeare; The Tempest; Margaret Atwood; Hag-Seed; romance neo-shakespeariano; capital cultural.

"In this day and age Caliban is the favourite, everyone cheers for him"

(H ag-Seed, 21)

Margaret Atwood's Hag-Seed: The Tempest Retold (2016) is a multilayered novel that imaginatively transforms its ostensible source text. Critics may come that will regard it as a palimpsest of Shakespeare's and later works (including her own), an elegant example of latter-day sophisticated intertextuality or a postpostmodern take on a canonical play which retrieves humanist readings of the artist-magician Prospero after decades of distrusting him as a patriarchal tyrant and a proto-colonizer. Whatever critical metaphor we adopt to explain the intricate power of this novel, its multifaceted complexity and its wealth, the fact remains that Atwood's text is a tribute to Shakespeare in a year of countless world-wide tributes to the Bard. What her teacher Northrop Frye described, referring to the 1964 anniversary of Shakespeare's birth, as our "superstitious reverence for the decimal system of counting" $(1965,4)$ has acted again in 2016 as a catalyst for the celebration of his legacy. H ag-Seed retells Shakespeare's The Tempest for a twentyfirst-century readership in the form of fiction, transferring the actions from the magic island of the original play to contemporary 
Canada. For many critics, among them Atwood's fellow Canadian Frye, "the subject of this play is the producing of a play" $(1986,172)$, and this is the overall understanding of The Tempest that she uses in $\mathrm{H}$ ag-Seed, a novel that celebrates the potential and power of Shakespeare's drama. ${ }^{1}$

The 2016 commemoration has been a momentous occasion for academic and cultural institutions in the UK and throughout the world to revisit the Bard's works and reexamine their position in contemporary society. Given that "the metaphor for literary and artistic value [...] as cultural capital is rapidly becoming commonplace" (Hedrick and Reynolds 2000, 6), we could say that in the anniversary year Shakespeare's cultural capital keeps on circulating more energetically than ever and with no signs of abatement. Each generation reads, performs and interprets Shakespeare in its own image, and the commemoration has generated a wide-spread urge to reconsider how his works can still talk to us and how Shakespeare can be, as Jan Kott famously phrased it in the sixties, our contemporary. Hag-Seed is Margaret Atwood's sixteenth novel and it was conceived and written as part of a larger project of fictional retellings of Shakespeare's plays devised by Hogarth Press for the celebration of the anniversary-with the publishing house undoubtedly hoping to ride the wave of greater Bard visibility and enhanced interest in his work this year: "The world's favourite playwright. Today's best-loved novelists. Timeless stories retold" ("Hogarth").

The collection celebrates the Bard's enduring power to inspire: it presents novels by respected contemporary authors that transport his characters and plots from their original locations and time to our own. The collection is premised on the idea that Shakespeare was a great reteller of stories, and it aims "to continue this tradition and celebrate his legacy, introducing his plays to a new generation of fans worldwide [...]. The books are true to the spirit of the original plays, while giving authors an exciting opportunity to do something new" ("Cover"). This is indeed a thrilling premise that obviates the conundrum of what constitutes "Shakespeare" and to what extent

\footnotetext{
${ }^{1}$ A twood credits three studies of Shakespeare in the acknowledgments: Frye's chapter on the play in his 1986 volume, Stephen Orgel's introduction to the 1987 Oxford edition, and Andrew Dickson's popular volume on Shakespeare gone global, W orlds Elsewhere (2015).
} 
we are sustaining, assimilating or dissolving his plays when we change his actions, his characters and, crucially, his language. The series began with the publication of Jeanette Winterson's update of The Winter's Tale in The Gap of Time in October 2015, followed by Howard Jacobson's Shylock is M y N ame (his take on The M erchant of V enice) in February 2016, Anne Tyler's Vinegar Girl (her version of The Taming of the Shrew) in June 2016, and Margaret Atwood's retelling of The Tempest in $\mathrm{H}$ ag-Seed in October 2016. ${ }^{2}$

The frame of the Hogarth collection forces the writers to never lose sight of Shakespeare's work and make sure that readers find enough elements that they can recognize from the plays. Given the specific conception of the series as both tribute to and modernizing of Shakespeare's plays, as a rewriting of The Tempest Hag-Seed occupies a peculiar position in relation to concepts such as adaptation, appropriation, intertextuality, revision, collaboration, interpellation and other varied attempts to charter engagements with Shakespeare's work. Adaptation and appropriation seem to be in recent years among the most frequently used concepts, although no discussion to date seems to establish a definitive distinction between them and, indeed, what Julie Sanders stated in 2001 is still true: "the terms in which this area of interest is articulated-adaptation, appropriation, reworking, revision-remain a site of contestation and debate" $(2001,1)$. The articulation of such a field is beyond the scope of the present analysis, but the awareness of its complexity provides some context for the difficulty of assigning a label to what Atwood does with The Tempest in H ag-Seed. Thomas Cartelli (1999), for instance, establishes differences between adaptation and appropriation in terms of the author's attitude towards the so-called original text, with appropriations pivoting more on the author's goals and adaptations more openly paying a tribute to it, while Sanders (2006) uses in her analysis of these two concepts the idea of closeness (adaptations) and distance (appropriations) from the earlier text. Sanders herself describes appropriation elsewhere as "the rendering apposite or appropriate, as it were, of Shakespearean drama in another context" (2001, 3). Whatever terminology they use, all contemporary discussions of engagements with pretexts, from

\footnotetext{
${ }^{2}$ The other novels to be published in the series will be retellings of 0 thello by Tracy Chevalier, $\mathrm{H}$ amlet by Gillian Flynn, M acbeth by Jo Nesbo and King Lear by Edward St Aubyn.
} 
Linda Hutcheon's general A Theory of A daptation (2006) to Alexa Huang and Elizabeth Rivlin's very specific Shakespeare and the Ethics of A ppropriation (2014), share the intellectual need to dignify the later texts not as derivative but as profoundly creative, their engagement with the so-called original not diminishing but enhancing their inventiveness and power. ${ }^{3}$

To the extent that Hag-Seed is a tribute to Shakespeare (and it clearly is), the novel would fit more easily into Cartelli's definition of adaptation, while in Sanders' terms of closeness, Atwood's transference from drama to fiction, with actions and characters in contemporary Canada and for the most part within a correctional center, would seem to suggest that her novel falls more clearly within Sanders' definition of appropriation. And yet, matters are far from clear-cut, since the resonances of The Tempest in the novel are at the same time obvious and discreet, blatant and nearly invisible. And, as to the agenda of the author, again, in the hall of mirrors that is the novel, the most evident intention is to pay tribute to Shakespeare and celebrate the power of his work to entertain, educate and make us human. And yet, again, Atwood the magician cannot resist the challenge to seize The Tempest and make it her own-or, as we will see, collaborate with Shakespeare to make something of their own. Her revisiting of the play has restrictions imposed by the Hogarth frame that were never in place for previous fictions related to The Tempest, from women's novels like Michelle Cliff's No Telephone to Heaven (1987), Rachel Ingalls's M rs Caliban (1982), Gloria Naylor's M ama Day (1988), Marina Warner's Indigo (1992), or Canadian revisions of Miranda as the country such as Margaret Laurence's The Diviners (1976), to Caribbean male engagements like Aimé Césaire's play U ne Tempête (1969) or George Lamming's novel W ater with Berries (1972), just to name a few. ${ }^{4}$

The feat of keeping a recognizable Shakespeare play while bringing it into the twenty-first century as a work of fiction is a tough balancing act, particularly in the case of this late romance.

\footnotetext{
${ }^{3}$ For a recent summary of similarities and difference between adaptation and appropriation, see Desmet and lyengar (2015).

${ }^{4}$ Careful analysis of creative engagements with The Tempest is provided by Zabus (2002). For women's revisions of this and other Shakespearean plays see N ovy (1999) and Sanders (2001). For the vitality of The Tempest as a source of inspiration and debate see Hulme and Sherman (2000).
} 
After rereading The Tempest several times, Atwood thought that it would be an impossibletask:

What was the modern-day equivalent of a magician marooned on an island for 12 years with a now adolescent daughter? You couldn't write that straight. [...] And what about the flying air spirit? And the Caliban figure?

Calm, calm, I told myself. I read the play again, this time backwards. The last three words Prospero says are "Set me free." But free from what? In what has he been imprisoned?

I started counting up the prisons and imprisonments in the book. There are a lot of them. In fact, every one of the characters is constrained at some point in the play. This was suggestive. [...] So I decided to set my novel in a prison. (A twood 2016b)

There are specific challenges in the project to turn The Tempest into a narrative work, essentially the fact that there is very little plot in it, but also that it mixes comedy, tragedy and romance. Atwood is a truly gifted mixer and re-maker of literary genres and here she constructs a light narrative which nevertheless includes tragic and elegiac elements. The Tempest is Shakespeare's “most neo-classical play" (Daniell 1989, 17) since, unlike the others, it follows the unities of time and place, with events unfolding over the course of a few hours in one single setting: the mysterious Mediterranean/ New World/ unlocated island where Prospero has been living for twelve years with his daughter Miranda and his two servants Ariel and Caliban. In The Tempest Shakespeare seems not so much interested in telling a story (Prospero does so in 1.2) as intent on exploring the very act of constructing and staging a performance, and criticism of the play has frequently highlighted its connections with the ceremonial form of the masque. ${ }^{5}$ The Tempest can thus be read as a metatheatrical text about an aged director who seems to believe in the nobleness of his enterprise as a means to an end, but also as an engrossing project in and of itself. This is the general interpretation of the play that A twood has transferred to her novel $\mathrm{H}$ ag-Seed.

Margaret Atwood first encountered Shakespeare's plays in her Toronto high school in the fifties (she also saw there her first performances, by the Earle Grey Players), and then at Victoria

\footnotetext{
${ }^{5}$ Significant analyses of the relation of The Tempest to Renaissance masque are provided among others by Gurr (2014), Lindley (1984) and Orgel (1987).
} 
college, where Frye was her teacher. ${ }^{6}$ She has responded to Shakespeare's works in previous fiction, including her toying with the characters of Gertrude and Horatio to provide new perspectives on $\mathrm{H}$ amlet in her short stories "Gertrude Talks Back" (Good Bones, 1992) and "Horatio's Version" (The Tent, 2007), the echoes of King Lear in Cat's Eye (1988), which incorporates an Earle Grey Players' performance of $M$ acbeth turned comic by the change in one of the props, and the integration of a production of Richard III in the park in the opening of "Revenant" (Stone M attress, 2014)-an inventive, outlandish take on the play in line with some of the Shakespearean productions mentioned in $\mathrm{H}$ ag-Seed. Atwood has explained that she has always been drawn to The Tempest because of the many questions it leaves unanswered and because of its generic complexity as "an early multimedia musical" (Blurb): "If Shakespeare were writing today, he'd be using every special effect technology now makes available" (Blurb). Her Prospero, the ill-fated theater director Felix Phillips (his name a tribute to Robin Phillips, who ran the Stratford Festival in Ontario in the late 1970s), lives for the theater and his obsession is "to create the lushest, the most beautiful, the most awe-inspiring, the most inventive, the most numinous theatrical experiences ever" (Atwood 2016a, 12). She chose to rewrite The Tempest because it has al ways been a favorite of hers for its focus on the theater: while others such as $\mathrm{H}$ amlet include a play-withinthe play, this is "the closest Shakespeare gets to writing a play about putting on a play" ("The N ext Chapter" 1:09).

Prospero can be seen as a metaphorical theater director who stages all the events on the island to create the result that he is looking for; as on the platform of a playhouse, he moves characters around, rearranges groups, creates special effects and even appears at the end to engage with the audience, who both are and are not the actual audience of the play. Unlike Puck, who fully steps out of character at the end of $A$ M idsummer $N$ ight's D ream to request applause, Prospero's status as an actor outside the play is less clear in his epilogue, as he involves the audience in the play's actions

\footnotetext{
${ }^{6}$ With his leanings towards comedy and romance and a temperament prone to focus on spiritual regeneration, Frye came naturally to have a special predilection for The Tempest, a play that he read as an embodiment of the values of forgiveness and restoration.
} 
("Gentle breath of yours my sails| Must fill, or else my project fails" [Epilogue, 12-13]), thus blurring the distinction between on-stage illusion and off-stage reality. In $\mathrm{H}$ ag-Seed Atwood recreates Prospero as the artistic director of the imaginary Makeshiweg Shakespeare Festival-very much itself a fictional recreation of the Stratford Festival in Ontario that she has attended throughout her life-who, after being ousted from his post by his more world-savvy deputy, Tony Price, lives in solitude for twelve years and plots his revenge on those who betrayed him. ${ }^{7}$ Felix's agents of retribution are the inmates turned actors in a prison production of The Tempest that will be attended by his adversaries, now important leaders in the community that will be supervising first-hand its literacy program. Atwood has significantly named the prison, in a humorous nod to Renaissance theater lovers, the Fletcher Correctional Center (and Felix's troupe of actors The Fletcher Players)-its reference to Shakespeare's collaborator John Fletcher witty shorthand for the collaborative nature of the novel at hand: Atwood and Shakespeare, Shakespeare and A twood.

The Tempest hinges upon the belief in magic, a premise that goes against our contemporary understanding of how the world works. Winterson's The Gap of Time resorts to video games to capture some of the unreal atmosphere of a play in which, among other things, Time enters with an hourglass. Magic in Atwood's novel gets transferred to forms that contemporary readers can relate to, such as the impact and possibilities of audio-visual and digital media, the internet or the hallucinatory effects of recreational drugs-although a pervading sense remains that a key magic strand in the universe created by Atwood is the power of the theater, of performance and art to fashion alternate worlds and shape realities that have the potential to produce, like director Felix's plays in the novel, "the collective indrawn breath, the collective sigh" (Atwood 2016a, 12), but also to allow us to know ourselves better. The original Prospero is absorbed in his magic books; Atwood's protagonist is obsessed with extreme staging angles that may deliver exceptional Shakespeare productions. As he himself admits, "he may on occasion have taken things too far. To be fair, more than on occasion;

\footnotetext{
${ }^{7}$ The comic perspective on the Stratford Festival presented through Felix in $\mathrm{H}$ ag-Seed bears some resemblance to the Canadian television series, Slings and A rrows (20032006). I am grateful to one of the SEDERI readers for bringing this to my attention.
} 
taking things too far had been his trademark" (Atwood 2016a, 33; emphasis in the original). When Felix is ousted from his post as the artistic director of the Makeshiweg Festival, he is preparing a cutting-edge version of The Tempest that could walk dangerously close to the precipice of farce:

His A riel, he'd decided, would be played by a transvestite on stilts who'd transform into a giant firefly at significant moments. His Caliban would be a scabby street person-black or maybe Nativeand a paraplegic as well, pushing himself around on an oversized skateboard. Stephano and Trinculo? He hadn't worked them out yet, but bowler hats and codpieces would be involved. And juggling: Trinculo could juggle some things that he might pick up on the beach of the magic island, such as squids. (Atwood 2016a, 16)

The Tempest is one of a few plays which seem to have been fully original creations of the Bard. Curiously, then, Atwood has chosen to rewrite as part of this series of novels that celebrate Shakespeare as a great reteller of stories one of the few in which the actions, characters and events were entirely his own. His use of previous sources is limited to very specific ideas or passages, the most significant being Prospero's speech renouncing his magic in 5.1, (related to Ovid's Medea), Ariel's removal of the banquet in 3.3 (related to Virgil's story of Phineus in the A eneid), and Gonzalo's envisioning of an ideal future commonwealth on the island in 2.1 (inspired by Michel de Montaigne's essay "Of Cannibals"). ${ }^{8}$ The Tempest is generally regarded as the Bard's last solo-authored play, and there is a long tradition of reading Prospero's final speech renouncing his magic as Shakespeare's farewell to the stage before retiring to live his final days in Stratford. In her collection of essays about writing, significantly entitled Negotiating with the Dead, Atwood discusses Prospero as an artist: "Without his art, Prospero would be unable to rule. It's this that gives him power [...] altogether, he is an ambiguous gentleman. Well, of course he is ambiguous-he is an artist, after all" (2002, 115). Ever since John Dryden and William Davenant adapted it to late seventeenth-century taste in The Enchanted Island (1667-1670) — which became a musical in Thomas Shadwell's operatic version in 1674- “The Tempest has been reread

\footnotetext{
${ }^{8}$ Detailed analyses of The Tempest in relation to these authors are provided by Bate (1993), Hamilton (1990) and Gurr (2014).
} 
and rewritten more radically, perhaps, than any other play. Long a source of inspiration and provocation for writers and artists, it has also emerged as one of the most contested texts in the critical sphere" (Hulme and Sherman 2000, xi).

Given the possible symbolic nature of the actions on the island, critical analyses of the play have been extremely varied, but a clear tendency towards demystifying the benevolent nature of Prospero and his plots has been sensed in the last decades of the twentieth century, with the development of neo-historicist, cultural material ist, feminist and postcolonial approaches to the plays. Postcolonial readings have seen it as a paradigmatic example of the encounter between colonizer and colonized. Feminist critics like Ann Thompson have explored the ideology of femininity in a text which, as she observes, significantly seems to deny the importance (even the presence) of female characters yet does "attribute enormous power to female chastity and fertility" (1998, 239). Like feminist interpretations, neo-historicist, cultural materialist and postcolonial readings have focused on the dynamics of power and inequality in the play and considered how Prospero uses and abuses his magic superiority on the island to regain his previous position of power. ${ }^{9}$ Although many critics no longer read The Tempest as a story of forgiveness and reconciliation, in the world of the theater and in popular culture, however, "the view [...] of Prospero as an essentially benevolent surrogate of Shakespeare the dramatist [has] never disappeared entirely" (Vaughan 2014, 38).

The title of Margaret Atwood's rewriting of The Tempest plays with our expectations, since "hag seed" is one of the insults that Prospero hurls at Caliban (by way of his mother Sycorax). Readers may approach the novel expecting to find what Edward Said would call a contrapuntal reading, an interpretation that shows "awareness both of the metropolitan history that is narrated and of those other histories against which (and together with which) the dominating discourse acts" (1993, 51). The obvious contrapuntal reading in a novel with this title would be to place Caliban's subjugation at its center, but the focus of $\mathrm{Hag}$-Seed is not the subaltern voice of the monster servant but Prospero, the magician himself, who focalizes

\footnotetext{
${ }^{9}$ Classic examples of these readings would be for instance Barker and Hulme (1985), Brown (1985), Cartelli (1999), and Greenblatt's chapter on The Tempest that gives the title to his 1990 volume.
} 
the narrative. As we have seen, by the late twentieth century "it became necessary to wrest from the Shakespeare canon an emblem of postcoloniality and to rewrite The Tempest from Caliban's perspective" (Zabus 2002, 9; emphasis in the original). Atwood's novel runs against this trend, and even though its title points to Caliban, his voice finds its way in a more indirect way through the prison inmates that Felix teaches. He certainly does not take center stage, as the title may suggest, although he is heard in the inmates' awareness that they all possess something of Caliban:

Now Hag-Seed's black and Hag-Seed's brown,

Hag-Seed's red, don't care if you frown,

Hag-Seed's yellow and Hag-Seed's trash white,

Hegoes by a lotta names, he's roaming in the night,

You treated him bad, now he's a sackful of fright. (A twood 2016a, 271)

Many of the dramatis personae in the play are metamorphosed into easily recognizable characters in the novel: Prospero's brother Antonio becomes Tony Price, Felix's ambitious colleague at the Makeshiweg Shakespeare Festival, "the evil-hearted, socialclambering, Machiavellian foot-licker" (Atwood 2016a, 11) who ousts him from his job and eventually becomes Heritage Minister. The honest old Gonzalo is the tender-hearted Lonnie Gordon, the chairman of the festival board who retrieves for him his annotated Tempest script when he is removed from his post. Felix's scheme to avenge himself and regain his job will unfold when Tony and others visit his prison: Justice Minister Sal O'Nally (Alonso, King of Naples), his son Frederick O'Nally (Ferdinand) and Sebert Stanley (Sebastian, Alonso's brother), a high-level politician who is rumored to be competing with O'Nally for party leadership. These are all supporting characters in the original play, in which the former Duke of Milan gets more than one quarter of the lines. The dissenting voice of Caliban is kept under control by magic, his obedient daughter Miranda has little to say and his other servant Ariel is fixated on regaining his liberty and is thus for the most part unwilling to contradict his master.

Atwood focuses her narration on Prospero, Miranda, Ariel and Caliban, even if only Prospero's role exists as a well-defined double of the original. There is no easy summation of the intricate mappings 
of the other three characters onto Atwood's multiple and multifaceted reincarnations. In the novel Felix's real daughter Miranda is dead, but she is resurrected several times in different forms (in Felix's mind, in theatrical performance and in a surrogate daughter figure that life brings his way). As in the play, Ariel has shifting shapes: his role is taken over in part by the ghost of Miranda, half vision of desire half hallucination, and for Felix, always, the beloved daughter that keeps him company; but Ariel's tasks are also performed by the inmates-actors who help him in his plans. The character of Caliban, the hag-seed of the title (or at least one of them), is disembodied and re-constituted as a multifarious collective, the group of inmates at the Fletcher Correctional Center that Felix instructs in the works of Shakespeare. In this way, the monster/ savage/ subjugated slave of the original play is transformed into a repository of the very human foibles and failures of a Canadian prison, with a multicultural population of colorful names (Leggs, PPod, Bent Pencil, Wonderboy, 8Handz) with personalities to match.

The five sections in $\mathrm{Hag}$-Seed correspond to the conventional division of Shakespeare's plays into five acts and the novel adds a "Prologue" to the original play. It also includes an "Epilogue" which presents Felix, as Prospero in Shakespeare's text, after the performance of his play. The added prologue is real ly a recreation of 1.1: while Shakespeare begins with Prospero's foes fighting death by drowning in a tempest which is only Ariel's crafted illusion, the prologue in the novel is a prolepsis of chapter 34, entitled "Tempest," which shows the planned turmoil that sets in motion Felix's revenge. In the first example of the Chinese-boxes structure of this novel, Hag-Seed ingeniously opens like The Tempest with the sinking of the court characters into a sea of confusion. The Ghent University professor that supervises the prison literacy program, who regularly meets Felix to discuss teaching in a restaurant appropriately called Zenith, facilitates the visit of his former enemies: "He could scarcely believe his luck. His enemies, both of them! They'd be right there in Fletcher! The one place in the world where, with judicious timing, he might be able to wield more power than they could" (Atwood 2016a, 70). She is the fictional embodiment of Lady Fortune and Prospero's lucky star and is fittingly called Estella: "You are such a star', he said" (71); "a true star, he tells her: his Lady Luck" (193). 
The sense of immediacy that the unity of time creates in The Tempest is recreated in $\mathrm{H}$ ag-Seed by the use of the present tense throughout the narrative, which unfolds in early 2013, when FelixProspero is preparing his production of The Tempest at the Fletcher Correctional Center. When the novel starts after the prologue, Felix is looking at himself in the mirror one morning as he gets ready to begin his fourth year as a prison instructor. As in The Tempest with Prospero and his dukedom, it has been twelve years since he was ousted from his job. In this multi-layered novel, there are several versions of Prospero's island, mainly the hut where Felix lives as the retired schoolteacher Mr Duke, but also the correctional facility itself where he prepares his Tempest, particularly the rooms in the building used for rehearsals and recordings of performances: "This is the extent of it, Felix muses. My island domain. My place of exile. My penance. My theatre" (Atwood 2016a, 81)-and indeed the everpresent island of guilt where he has been marooned since the death of his daughter.

Section I of the novel, entitled "Dark Backward" after Prospero's description of Miranda's first memories as "the dark backward and abysm of time" (1.2.62), presents the backstory of Felix in the only chapters in the novel which use the past tense. Atwood creates here an ingenious mapping of Prospero's speech to Miranda about their past in 1.2. In the play this is a difficult moment to stage, as Felix is well aware: “He's right, thinks Felix. That scene's been a challenge for every actor who's ever played Prospero: how to get through the Act I, scene 2 narration of Prospero's doleful history while at the same time making it compelling. The thing is too static" (A twood 2016a, 155). Prospero and Miranda were put on a boat and cast into the sea, and Felix's remembrance of how he left the Makeshiweg Festival contains hints of his movement away as progress by water, since he "didn't have the sensation of driving. Instead he felt he was being driven, as if blown by a high wind" (Atwood 2016a, 29); he felt "adrift" (30), surrounded by "islands of trees" (30), and his lost daughter Miranda "dead in the water" (33). When he finds in his alter ego Mr Duke a new life that allows him to feel that he "may be washed up, but F. Duke may still have a chance" (37), he looks at his Prospero cloak, which appears to him as "the dead husk of his drowned self" (63). Thinking about his dead daughter in rehearsals Felix feels "lost at sea, drifting here, drifting there. In a rotten carcass the very rats have quit" (160). Later on, when the preparations for 
the prison Tempest make him more hopeful, his thoughts are reminiscent of the metaphor of transformation by drowning in Ariel's song in 1.2: "No, not dead, but changed. In the gloom, in the gloaming, it's been transforming itself, slowing coming alive [...] Rich and strange. The many pearly eyes twinkle at him from the underwater darkness" (63-64).

When $\mathrm{H}$ ag-Seed opens in January 2013 Miranda has been dead for twelve years. This is the major change that Atwood introduces in Prospero's backstory: the recently widowed Felix lost his daughter, self-consciously named Miranda, when she was three years old while he was self-absorbed in a production. After losing her, he had used his obsession with the theater as a healing mechanism: "Right after the funeral with his pathetically small coffin he'd plunged himself into The Tempest. It was an evasion, he knew that much about himself even then, but it was also a kind of reincarnation [...]. Through her, his Miranda would come back to live" (Atwood 2016, 15-16). When he loses his job and removes himself from the world of the theater, his chance to bring back his daughter is lost too: "with the destruction of his Tempest, the new Miranda-the Miranda he'd been intending to create, or possibly to resurrect-was dead in the water" (32). In his isolation, Felix begins to feel that his daughter is "still with him, only invisible" (45). Like an actor that gets fully involved in a role, "a conceit, a whimsy, a piece of acting: he didn't really believe it, but he engaged in this non-reality as if it were real" (45), he starts to get children's books out of the local library, to help Miranda with her homework, and to teach her how to play chess: "She was a quick learner, and was soon beating him two times out of three" (45). Felix is both aware and not aware that his daughter is dead, so that we find moments of intimate conversation and interaction with Miranda about the minutest details of his daily life ("He needs a scarf [...] he's put it somewhere, but where? In the big old armoire in the bedroom, Miranda reminds him gently," 63); but he also reflects on her disappearance, as when he sees the school bus drive close to his hut: "Miranda might have been on a school bus once, if she'd ever reached that age" (63). On the whole, her presence is so powerful that he follows her growth in real time into 
adolescence, and so by the time he performs his prison Tempest his Miranda is, like Prospero's, a beautiful fifteen-year-old girl. ${ }^{10}$

Some reviewers of the novel have pointed out that the tragic, elegiac tone of this section sits in uncomfortably with the mostly comic, bordering on romp, unfolding of the overall narrative. In an otherwise enthusiastic review that describes the text as a neoShakespearean novel and claims that "students will learn more about the deeper meanings of The Tempest from this singular novel than from dozens of academic studies" (Bate 2016), Jonathan Bate refers to this part as "the only element that maps awkwardly on to the original" and states that "[Felix and Miranda's] shadowy dialogues seem to come from another genre" (2016). Indeed, The Tempest mixes tragic, comic and romance elements and the case could be made that the tragic elements in the play have been transferred to Felix's relation with his daughter, so that Alonso's suffering for his dead child Ferdinand, which in the original turns out to be only a temporary illusion, is reassigned in Atwood's novel to the reality that Felix's mind tries to amend with illusion, since he lives in permanent guilt for not having been there for her as an infant: “They can't possibly know anything about him, him and his remorse, his self-castigation, his endless grief" (Atwood 2016a, 160).

A nother possible reason for A twood's intervention in the plot of the play may have to do with Miranda's status as obedient daughter in The Tempest. At points one gets the feeling that in a twenty-firstcentury recasting of the play only a dead Miranda whose ghost Felix conjures up at will could fulfil the role of docile daughter that we find in the original. Indeed, as we saw earlier, this has become a source of discomfort for feminist critics, who find little female agency in this play in which Miranda is the only woman on the island and the females that are mentioned are considered evil (Caliban's mother, the witch Sycorax) or mere marriage goods (Ferdinand's sister, Claribel). Miranda is a problematic character for many contemporary readers who see her as the submissive daughter who follows her father's orders and is given little space to maneuver into agency of any kind. In section I she can fulfil as a ghost the function she has in act I of the play: she is a reassuring presence that

\footnotetext{
${ }^{10}$ Atwood mentions relevant sources on this topic in the acknowledgements section at the end: "And much about conversing with loved ones and other strange experiences can be learned in The Third M an Factor, by John Geiger" (Atwood 2016a, 293).
} 
calms Prospero-Felix into the conviction that he is not to blame for what happened, that his vision of the past is the only true one: Miranda "nods because she knows that to be true [...] noble people [...] sprout benevolent acts the way trees sprout leaves. And Felix, in the eyes of Miranda, is noble. It helps him to know that" (Atwood 2016a, 61).

When he reencounters his enemies and revenge is possible, Felix has been working as the English instructor in the prison's Literacy through Literature program for four years. He has brought into it his spirit of innovation and switched the students from reading novels like The Catcher in the Rye to performing plays by Shakespeare. Following the study routine that he has developed, the inmates carefully analyze his adapted version of the play under his guidance before attempting the performance. Prospero-Felix senses the beneficial influence his work has on the inmates when their performances are shown on the prison closed-circuit TV: "Watching the many faces watching their own faces as they pretended to be someone else-Felix found that strangely moving. For once in their lives, they loved themselves" (Atwood 2016a, 58). These are moments when Felix feels indeed like the original Prospero an agent of regeneration for his students and he sees himself as the vehicle for positive transformation, although he will have no qualms about using them for his own plan of revenge while presenting it as a move to defend their Literacy through Literature program, claiming like Prospero with his daughter that he has done nothing "but in care of thee" (1.2.19).

When Felix first introduces The Tempest to his Fletcher actors (he refuses to call them or think of them as inmates) he gets a more negative reaction than in previous years:

Using the blue marker he writes:

IT'S A MUSICAL: Has the most music + songs in Shkspr. Music used for what?

MAGIC: Used for what?

PRISONS: How many?

MONSTERS: Who is one?

REVENGE: Who wants it? Why? 
Consulting their faces-Stony, frowning, or blankly bewilderedhe thinks: they don't get it. N ot like Julius Caesar, not like M acbeth. They saw the point of those right away. (A twood 2016a, 86)

The Tempest is the fourth play he presents, after Julius Caesar, Richard III and M acbeth, which were texts about "power struggles, treacheries, crimes: these subjects were immediately grasped by his students, since in their own ways they were experts in them" (Atwood 2016a, 55). The Tempest has no battles and it involves magic but not witches (the ones in $\mathrm{M}$ acbeth had been a success), so he must use his imagination to create interest among his cast by describing its actions in terms that they can understand and creating a sense of magic that they can relate to.

Felix presents The Tempest to his actors as a story about prisons, prisoners and jailers, so that by bringing the play to the context of the readers, Shakespeare speaks to their specific situation and becomes relevant for them. Felix sees the play as full of prison images and in the acknowledgements section A twood calls attention to the prison literature that has inspired and helped her in her retelling of The Tempest. ${ }^{11}$ While inmates can easily relate to ideas of imprisonment and revenge in the play, other elements are remote from their experience, and this opens the way for Felix-Atwood's creativity: for instance, to sell the role of Ariel to his actors, who are reluctant to volunteer to play a fairy, he builds up the case for this character as a stranger, possibly an alien from outer space with special superpowers. As they come to perceive Ariel in these terms there is a lot more interest in the role, particularly when Felix presents him as the one who is in charge of magic, understood in a way that his actors can easily grasp: "If he were here with us now, he'd be called the special effects guy [...] he is like a digital expert. He's doing 3-D virtual reality" (Atwood 2016a, 104). His discussions are delightful explorations of various aspects of The Tempest, and seasoned teachers among readers will sympathize with his efforts to make the Bard meaningful for his students as he strives to convince them that "Shakespeare has something for everyone, because that's

\footnotetext{
${ }^{11}$ A twood mentions her interest in books about "literature and drama being taught or being experienced within prisons" (2016a, 292) and she explicitly credits Laura Bate's 2012 memoirs Shakespeare Saved M y Life, which she describes as "encouraging" (2016a, 292). The use of Shakespeare in the prison system has become the focus of serious study in recent years, as in Scott-Douglass (2007) or Lehman (2014).
} 
who his audience was: everyone, from high to low and back again" (Atwood 2016a, 84). Or as Sanders states, "Shakespeare [...] appears to be about inclusion, about making space for everyone to have a voice" (2001, 188).

When Felix gives the inmates the choice of role they would like to play, fifteen out of twenty actors choose Caliban, mainly because they identify with his situation of oppression and his attempts to rebel against it:

"So why do you want to play him?"

"He is poxy awesome."

"Weget him."

"Everyone kicks him around but he don't let it break him, he says what hethinks." This from Leggs.

"He's mean," says Shiv. "Wicked mean! Everyone who's dissing him, he wants to get them back!" (Atwood 2016a, 120)

Additionally, Felix provides multiple angles into Caliban for his class by arguing that he is musical and loves singing and dancing, he has local knowledge of the island, he has the most poetic speech in the play about his beautiful dreams, and he is searching for revenge since he feels that Prospero has stolen the island from him (Atwood 2016a, 121). In the play, Caliban appears at the end of Act I; likewise, in the novel the Literacy through Literature program at the Fletcher Correctional is introduced at the end of Section 1, thus bringing into the narrative the collective Caliban created by Atwood. Instead of imprisoning him/ them, Felix contributes to a liberation of sorts through their travelling with Shakespeare and their escape into the theater: unlike the original Caliban, who wants to steal Prospero's magic books to strip him of his magic, Atwood's multiple Calibans appear to receive willingly the knowledge of Felix-Prospero's books -Shakespeare's plays. Felix shares with them the language of art and performance, beginning with their attraction to the cursing in Shakespeare's texts. Each inmate-actor gets to choose ten swear words from the text which he can use in their class discussion and rehearsals, making thus Shakespeare's language their own as variations and combinations of his swear words and bawdy 
language, which are frequently integrated in their interactions..$^{12}$ In the play Caliban says to Prospero "You taught me language and my profit on't / Is I know how to curse" (1.2.437-38); in the novel, Felix thinks about the inmates "Your profanity [...] has oft been your whoreson hag-born progenitor of literacy. Along with your whoreson cigarettes, may the red plague rid them" (Atwood 2016a, 89)-in his innovative program, swear words lead the inmates to the Bard, so that it could be argued that their improved literacy is indeed the hag-seed of the Bard's profanity. And Caliban's rebellion is thus channeled through language, as they learn how to curse in Shakespeare's idiom and later develop the skills to envision new endings for the play they are performing.

The motley crew into which Caliban becomes reincarnated in the novel are at the center of Section $V$ of the novel, significantly entitled "This thing of darkness," Prospero's famous final acknowledgement of Caliban as his own in act 5 . In this final section, A twood toys with the afterlives of the original characters by presenting Felix's final assignment to his students; the last class is reserved for their presentations on their understanding of what will happen to the characters when the play finishes, so that when the inmates gather to deliver their after-performance team reports Atwood's novel flaunts its ingenious straying from Shakespeare's play. Each team has thought out what will happen to the characters once the play ends and they leave (or do not leave) the island and $\mathrm{H}$ ag-Seed closes with several chapters devoted to possible afterlives of the characters and answers to some of the many questions left hanging in the play. Thus in the conclusions of the Caliban-inmates, for instance, Ariel does not vanish into thin air but "stays on earth and he flies off to tackle climate change" (Atwood 2016a, 248); Antonio remains unrepentant and allies himself again with Sebastian on the voyage back, the two of them killing everyone else on the ship-a version of the characters' afterlives that is contradicted by another version (by the one young actress that Felix has brought in to play Miranda) which reconstitutes Miranda as the natural inheritor of Prospero's magic who beats all of them; and the freed Caliban becomes a famous rapper after he is finally acknowledged and pampered by

\footnotetext{
${ }^{12}$ Atwood credits in the acknowledgements The Shakespeare Insult Generator. There several available online, but from her comments in interviews she is most likely referring to a 2014 volume by Barry Kraft.
} 
Prospero as the son he had with Sycorax (one version) or he is abandoned, festers in his rage and plans his revenge on Prospero (another, more generally appealing version):

Felix is intrigued. Caliban has escaped the play. [...] Now there's no one to restrain him. Will Prospero be spared, or will retribution climb in through the window one dark night and cut his weasand? Felix wonders. Gingerly, hefeels his neck. (Atwood 2016a, 272)

This multiplicity of endings allows Atwood to incorporate subversive, against-the-grain, re-visions of The Tempest that the tight premise of the Hogarth series has bounded in, and provides a glimpse of insights that could pan out into alternative appropriations of the play. Atwood's novel sketches thus, as in an afterthought, what Chantal Zabus describes as the center of recent appropriations of the play: “These 'alter-native' plots serve to dismantle narrative authority and to reorient the circulation of knowledge. The singular, punctual Tempest is ousted by Tempests, which accommodate the multiple instabilities of contemporary texts and contexts" (2002, 2).

After the multiple Calibans reinvent the lives of the characters in the play, the novel closes with the Epilogue, entitled with Prospero's words, "Set me Free." In The Tempest Prospero asks the audience to set him free; in the novel, Felix is finally free of the ghost of his daughter and the guilt that has marked his life since she died. This moment also works as the liberation of his most intimate ArielMiranda, the force that has made his last performance possible, and Felix's words are exactly those used by Prospero when liberating Ariel:

How selfish he has been! Yes, he loves her, his dear one, his only child. But he knows what shetruly wants, and what he owes her.

"To the elements be free," he says to her.

And, finally, sheis. (Atwood 2016a, 283)

Given Atwood's remarkable fan following there is a distinct possibility that more readers may come to read Shakespeare's original Tempest by way of her retelling. Atwood has claimed that fan fiction on a grand scale really started with the admirers of Shakespeare, who through the centuries have responded to his works and rewritten his stories in endless ways. She is fully aware that The Tempest has been done in all possible modes on the stage 
and other media and that it has been analyzed ad infinitum. ${ }^{13}$ When she took up this project she felt it was a daunting task, but she has compared the restrictions imposed on her novel by the previous work to the situation she had when creating The Penelopiad, her rewriting of the 0 dyssey. She sees the limitations imposed by the existing Tempest as not so different from the strictures created by set literary forms such as the sonnet: instead of limiting the resources of the writer, they can increase her creativity ("Margaret" 2015, 1.00.22).

The subtitle of the novel, The Tempest Retold, highlights the necessary nature of $\mathrm{H}$ ag-Seed as a retelling of a canonical play. In $N$ egotiating with the $D$ ead, Atwood discusses the inevitable dialogue that authors must maintain with those that preceded them: "All writers learn from the dead. As long as you continue to write, you continue to explore the work of writers who have preceded you; you are also judged and held to account by them" (A twood 2002, 178). In the case of $\mathrm{H}$ ag-Seed, the writer's negotiation with the dead is a particularly complex process, since Atwood's aim is to retell The Tempest to create a contemporary double of the original, a recognizable copy that is at the same time its own creature. The Tempest is commonly considered to be Shakespeare's last solo play, but Atwood's negotiations with the dead in this novel turns her Tempest Retold into an uncanny collaborative work in which Shakespeare contributes his Prospero and other characters, some of his basic premises and some of his language, but lets his collaborator play with them and transform them into something rich and strange. As for some of the characters of the original Tempest, this is a process of transformation by drowning-our drowning, the play's drowning -in the magic ocean of our suspension of disbelief.

A nother way to express what A twood does in this novel, a more wicked view of her negotiations with Shakespeare's text is provided by her choice of words at the end of the five-page summary of The Tempest which she includes in her book. While Winterson's summary of The Winter's Tale in The Gap of Time is placed before her novel (which she then labels with the music term "cover version"), Atwood chooses to include her summary, which she calls "The

\footnotetext{
${ }^{13}$ Atwood mentions three specific performances of the play in the acknowledgements: Julie Taymor's 2010 film with Helen Mirren as Prospera, the Globe on Screen 2013 production with Colin Adam as Prospero and the Stratford, Ontario 2010 version with Christopher Plummer as Prospero.
} 
Original," after her own retelling, so that it seems to work as her own teasing epilogue in the hall of mirrors that is Hag-Seed. Atwood's summary of the play closes with a reference to Prospero's epilogue, understood by her as his request to the audience to set him free "by using its own magic to applaud the play" (Atwood 2016a, 289; emphasis added), and thus Atwood's ending seems to be a playful wink to her devoted readers to apply their own magic in their response to this quirky, multifaceted, hag-seed of a novel which both is and is not The Tempest-a peculiar polymorphic creature that, like Caliban in the inmates' final reading of the play, is the offspring of two magicians: Shakespeare and A twood, A twood and Shakespeare.

\section{References}

A twood, Margaret. 1988. Cat's Eye. Toronto: McClelland and Stewart.

-_- 1992. Good Bones. Toronto: Coach House Press.

- - - 2002. Negotiating with the Dead: A Writer on Writing. Cambridge: Cambridge University Press.

- - . 2005. The Penelopiad. Edinburgh: Canongate Books.

- - - 2007. The Tent. New York: Knopf Doubleday.

- - . 2014. Stone M attress. Toronto: McClelland and Stewart.

- - . 2016a. H ag-Seed: The Tempest R etold. London: Hogarth.

- - C. 2016b. "A Perfect Storm: Margaret Atwood on Rewriting The Tempest." The Guardian, September 24, 2016. https:/ / www.theguardian.com/ books/ 2016/ sep/ 24/ margaret-atwoodrewriting-shakespeare-tempest-hagseed.

Barker, Francis, and Peter Hulme. 1985. "Nymphs and Reapers Heavily Vanish: The Discursive Con-Texts of The Tempest." In Alternative Shakespeares, edited by John Drakakis, 191-205. London and New York: Methuen.

Bate, Jonathan. 1993. Shakespeare and O vid. Oxford: Oxford University Press. - - . 2016. "H ag-Seed: The Tempest Retold by Margaret A twood." The Times, October 1, 2016. http:// www.thetimes.co.uk/ article/ hag-seed-thetempest-retol d-by-margaret-atwood-2bpnrmx2k.

Bate, Laura. 2013. Shakespeare Saved M y Life: Ten Y ears in Solitary with the Bard. Naperville, IL: Sourcebooks.

Brown, Paul. 1985. "'This thing of darkness I acknowledge mine': The Tempest and the Discourse of Colonialism." In Political Shakespeare: N ew Essays on Cultural $\mathrm{M}$ aterialism, edited by Jonathan Dollimore and Allan Sinfield, 48-71. Manchester: Manchester University Press. 
Cartelli, Thomas. 1999. Repositioning Shakespeare: National Formations, Postcolonial A ppropriations. London and N ew York: Routledge.

Césaire, Aimé. 1969. U ne Tempête. Paris: Éditions du Seuil.

Cliff, Michelle. 1987. N o T elephone to Heaven. New York: Plume.

"Cover and title revealed for Hag-Seed." Penguin Random House Canada, February 22, 2016. http:/ / penguinrandomhouse.ca/ news/ cover-andtitle-revealed-hag-seed-new-novel-margaret-atwood-hogarthshakespeare-series.

Daniell, David. 1989. The Tempest. London: Palgrave Macmillan.

Desmet, Christy, and Sujata Iyengar. 2015. "A daptation, A ppropriation or What You Will." Shakespeare 11 (1): 10-19.

Dickson, Andrew. 2015. W orlds Elsewhere: J ourneys around Shakespeare's Globe. London: Bodley Head.

Frye, Northrop. 1965. A N atural Perspective: The D evelopment of Shakespearean Comedy and Romance. New York and London: Columbia University Press.

- - . 1986. Northrop Frye on Shakespeare. New Haven: Yale University Press.

Greenblatt, Stephen. 1990. Learning to Curse: Essays in Early M odern Culture. New York and London: Routledge.

Gurr, Andrew. 2014. "New Directions: Sources and Creativity in The Tempest." In The Tempest: A Critical Reader, edited by Alden T. Vaughan and Virginia Mason Vaughan, 93-113. London: Bloomsbury.

Hamilton, Donna B. 1990. Virgil and The Tempest: The Politics of Imitation. Columbus: Ohio State University Press.

Hedrick, Donald, and Bryan Reynolds, eds. 2000. Shakespeare without Class: M isappropriation of Cultural Capital. New York: Palgrave.

"Hogarth Shakespeare." Last accessed August 2017. http:// crownpublishing. com/ hogarth-shakespeare/

Huang, Alexa, and Elizabeth Rivlin, eds. 2014. Shakespeare and the Ethics of A ppropriation. New York: Palgrave.

Hulme, Peter, and William H. Sherman, eds. 2000. The Tempest and Its Travels. London: Reaktion Books.

Hutcheon, Linda. 2006. A Theory of Adaptation. London and New York: Routledge.

Ingalls, Rachel. 1982. M rs Caliban. Boston: Harvard Common Press.

Kraft, Barry. 2014. The Shakespeare Insult Generator. San Francisco: Chronicle Books.

Lamming, George 1972. Water with Berries. New York: Holt, Rinehart and Winston.

Laurence, Margaret. 1976. The D iviners. Toronto: McClelland \& Stewart. 
Lehmann, Courtney. 2014. "Double Jeopardy: Shakespeare and Prison Theater." In Shakespeare and the Ethics of A ppropriation, edited by Alexa Huang and Elizabeth Rivlin, 89-105. New York: Palgrave.

Lindley, David. 1984. The Court M asque. Manchester: Manchester University Press.

"Margaret Atwood: Shakespeare in my Work." Stratford Festival Forum, 2015. https:/ / www.youtube.com/ watch?v=md-4oLobu04.

Naylor, Gloria. 1988. M ama D ay. New York: Vintage.

"The Next Chapter: Audio Interview with Margaret Atwood." CBC Listen, October 10, 2016.

http:// podcast.cbc.ca/ mp3/ podcasts/ nextchapter_20161010_25846.mp3

Novy, Marianne, ed. 1999. Transforming Shakespeare: Contemporary Women's

ReV isions in Literature and Performance. New York: St Martin's Press.

Orgel, Stephen. 1987. "Introduction." In The Tempest, edited by Stephen Orgel, 1-88. Oxford: Oxford University Press.

Said, Edward W. 1993. Culture and Imperialism. London: Vintage.

Sanders, Julie. 2001. N ovel Shakespeare: Twentieth-Century W omen N ovelists and A ppropriation. Manchester: Manchester University Press.

- - . 2006. A daptation and A ppropriation. London: Routledge.

Scott-Douglass, A my. 2007. Shakespeare Inside: The Bard Behind Bars. London: Continuum.

Shakespeare, William. 1987. The Tempest. Edited by Stephen Orgel. Oxford: Oxford University Press.

Thompson, Ann. 1998. "M iranda Where's Your Sister?" In Critical Essays on Shakespeare's The Tempest, edited by Virginia Mason Vaughan and Alden T. Vaughan, 234-44. New York: G.K. Hall.

Vaughan, Virginia Mason. 2014. "The Critical Backstory: 'What's Past is Prologue'." In The Tempest: A Critical Reader, edited by Alden T. Vaughan and Virginia Mason Vaughan, 13-38. London: Bloomsbury.

Warner, Marina. 1992. Indigo; or, M apping the Waters. London: Chatto \& Windus.

Winterson, Jeanette. 2015. The G ap of Time. London: Hogarth.

Zabus, Chantal. 2002. Tempests after Shakespeare. New York: Palgrave.

H ow to cite this article:

Muñoz-Valdivieso, Sofía. "Shakespeare our contemporary in 2016: Margaret

Atwood's rewriting of The Tempest in H ag-Seed" SED ERI 27 (2017): 105-29.

A uthor's contact: simunoz@uma.es

Postal address: Dpto. de Filología Inglesa, Francesa y Alemana - Facultad de Filosofía y

Letras - Universidad de Málaga. Campus de Teatinos - 29071 Málaga, Spain

Submission: 20/ 12/ 2016

A cceptance: 10/ 02/ 2017 


\title{
Introducing Shakespeare to the fringes of Europe: The first Romanian performance of The Merchant of Venice
}

\author{
Madalina Nicolaescu \\ U niversitatea din București, Romania
}

\begin{abstract}
V enice; melodrama.

\section{Introducción a Shakespeare en la periferia europea: la primera representación rumana de The Merchant of Vcnice}

ABSTRACT

Shakespeare was introduced into the Romanian Principalities between 1830 and 1855, beginning with a production of The M erchant of V enice, translated from a French adaptation of the play. This essay considers the dearth of critical attention paid to the influence of French melodrama in Southeastern Europe, and in Romania in particular; examines the circulation of Shakespearean productions in this area; and investigates the various processes of de-and re-contextualization involved in the melodramatic adaptation of The M erchant of Venice in France in the 1830s and in its translation/ performance in the Romanian Principalities in the 1850s.

KEYWORDS: Shakespeare in Romania; French adaptations; The M erchant of

RESUMEN: Shakespeare fue introducido en los Principados Rumanos entre 1830 y 1855, siendo la primera una producción de The $M$ erchant of $V$ enice, traducida a partir de una adaptación francesa de la obra. El presente trabajo considera la escasa atención crítica que se ha prestado a la influencia del melodrama francés en el sureste europeo, y en Rumanía en particular. Además, analiza la circulación de las producciones shakespearianas en esta zona, investigando los diversos procesos de descontextualización y recontextualización realizados en la adaptación melodramática de The $M$ erchant of $V$ enice en Francia en la década de 1830, y su traducción y representación en los Principados Rumanos en

\section{A Introdução de Shakespeare nas M argens da Europa: A Primeira Produção Romena de The M erchant of Venice* $^{*}$}

RESUMO: Shakespeare foi introduzido nos Principados Romenos entre 1830 e 1855, começando com uma produção de The $M$ erchant of $V$ enice, traduzido a partir de uma adaptação francesa da peça. Este ensaio considera a escassez de atenção crítica prestada à influência do melodrama francês no sudeste europeu e na Roménia em particular; examina-se a circulação de produções shakespearianas nesta região e investiga-se os vários processos de descontextualização e recontextualização envolvidos na adaptação melodramática de The $M$ erchant of V enice em França na década de 1830 e a sua tradução/ representação teatral nos Principados Romenos na década de 1850.

*Translation into Portuguese by Miguel Ramalhete. 
Nicolaescu

la década de 1850.

PALABRAS CLAVE: Shakespeare en

PALAVRAS-CHAVE: Shakespeare na Rumanía; adaptaciones francesas; The $M$ erchant of $V$ enice; melodrama.

Roménia; adaptações francesas; The

$M$ erchant of $V$ enice; melodrama.

\section{The mystery around the first Romanian Shylock performance}

While the dissemination of eighteenth-century German adaptations in Eastern Europe (mostly in the Habsburg Empire) has al ready been tackled, the spread of nineteenth-century French Romantic versions of Shakespeare has hardly been broached. ${ }^{1}$ This paper will look at the "French connection" of the transnational diffusion of Shakespeare in Eastern Europe and will focus on the Bard's early introduction into the Romanian Principalities (Wallachia and Moldavia) at a time when they were still part of the Ottoman Empire, but had recently been placed on Europe's map. This period starts with the peace of Adrianople between the Ottoman and Russian empires in 1829 and ends with another Russian-Turkish war, the Crimean War (1853-1856). It marks the beginning of modern Romanian society, when windows to Europe were eventually opened and Romanian society embarked on a speedy process of re-inventing itself. The introduction of Shakespeare in the Romanian Principalities was part of an important process of cultural import from France which made possible the break with the premodern Ottoman heritage and the redefinition of Romanian political and cultural identity in the terms of, and after the models offered by, Western societies.

As was the case in other (East)European cultures, French translations of English literature (Shakespeare included) played the role of mediators, ensuring access to English texts, in a context in which there was no direct contact with English culture. ${ }^{2}$ Earlier French rewritings of Shakespeare by Jean-François Ducis had a wide circulation in Europe, reaching Poland and Russia in the East, Spain

\footnotetext{
${ }^{1}$ Among the most important contributions on German and French adaptations see Schulze (1993, 55-74), Gibińska (2014), Minier (2014), and Nicolaescu (2014).

${ }^{2}$ On the role of French culture as European cultural mediator in the eighteenth and early nineteenth century, see Lambert $(1993,31)$. For the first Romanian translations of English literature via French versions, see Grimm (2012).
} 
and Portugal in the West or Italy in the South; they further provided the text for the earliest translations of Shakespeare in the respective languages. ${ }^{3}$ What is singular about the reception of the French Shakespeare in Romanian culture is that it occurred relatively late and did not involve Ducis's adaptations; what was introduced into the Romanian Principalities were the re-workings of the Romantic generation that rejected Ducis and the neo-classical norms associated with his "imitations." 4 While the cultural mediation and circulation of Ducis's plays has received much critical attention, the transnational dissemination of later romantic French adaptations of Shakespeare has largely been ignored. One reason for this lack of interest is the long staying power of Ducis, who was performed at the Comédie Française until late into the nineteenth century and the correspondingly tenuous hold that the Romantic Shakespeare had on the French elite stages. ${ }^{5}$ A nother reason has to do with the lack of cultural prestige of popular Shakespeare adaptations performed on Boulevard stages. ${ }^{6}$ While scholarship has paid scant attention to the Shakespeare performed on these stages, the diffusion of popular adaptations across the continent has been ignored altogether. ${ }^{7}$ This

${ }^{3}$ Ducis's adaptations were designed to re-work Shakespeare's texts so as to make them "fit" the norms and neoclassical restrictions in force in eighteenth-century France. $\mathrm{His}$ rewritings enjoyed a long lasting success on the stage of the Comédie Française until the latter half of the nineteenth century. For the major changes in plot, characters and versification introduced by Ducis to make Shakespeare acceptable to the French audience, see Willems $(2010,95-99)$ and Pemble $(2005,240-42)$. For an overview of Ducis's circulation in late eighteenth-century and early nineteenthcentury Europe, see Stokes $(2012,299)$.

${ }^{4}$ Ducis's views were powerfully contested by Victor Hugo and the other French romantic playwrights and poets in the 1830s. On Victor Hugo "as anti-Voltaire" and hence a critic of Ducis, see Willems (2010, 41-43).

${ }^{5}$ In Lambert's view, the relative failure of the Romantic Shakespeare to conquer the French stage and the persistence of the neo-classical Ducis were determined by the autonomy of the theater from the literary movements of nineteenth-century France. However, Lambert focuses almost exclusively on the elite theaters and disregards the popular ones (1993, 36-37).

${ }^{6}$ There is a recent critical movement towards the reconsideration of the theatrical innovations produced on the Boulevard stages which were long dismissed as spectacular and commercial (Thomasseau 2009).

7 Lambert acknowledges that Alexandre Dumas Sr. provided the "theatrical Shakespeare" of the nineteenth century $(1993,38)$, but does not discuss his Hamlet at Théâtre Historique. Pemble examines the Dumas-M eurice version of $\mathrm{H}$ amlet in greater details, though in a most disparaging manner (2005, 110-17). 
paper is going to focus on one of these popular melodramatic adaptations, once successful and now fallen into oblivion, and will follow its journey towards what was considered to be Europe's borderland, i.e. the Romanian Principalities. I will look at the double process of de and re-contextualization involved in reworking Shakespeare (in French and in Romanian). Particular emphasis will be placed on the cultural and political meanings first injected into Shakespeare in the French adaptation and then carried across and modified in the Romanian translation.

The first Shakespearean performance, staged in Iaşi (the capital of the Principality of Moldova) in 1850, was the Romanian version of a French adaptation of The $M$ erchant of $V$ enice, which in Romanian was entitled Shylock- sau Sânetul de singe [Shylock or the Blood Bond]. The title seemed to be subject to variation and uncertainty: the play was referred to as both The M erchant of V enice and Shylock. Unfortunately, the play text did not survive so that our analysis has to rely merely on the information provided by the review of this performance, where Shakespeare's title and the title of the adaptation were interchangeable (Burada 1975, 341). The same review described the play as having been written by the famous author Shakespeare, and it further specified that it was translated from French by A. Vasiliu. ${ }^{8}$ There is no mention of any adaptor or a translator of the Shakespearean text into French who might have given the play the title Shylock. One can infer that the Romanian public at that time was little interested in differentiating between the original and its French re-working. Hence the smooth passage from the title of the original to that of the adaptation. The Romanian translator A. Vasiliu was well-known within the Iaşi theater circles for his successful translation of Lamartelliere's adaptation of Schiller's play Die Rauber (The Bandits). Shakespeare, like Schiller and other European canonical writers (Young, Byron), was introduced to this part of Europe via French adaptation of the source text. Given the cultural

\footnotetext{
8 “Reprezentații dramei renumitului autor Sacspir, intitulată N eguțătorul din V eneția (Sânetul de Singe) ne-au dat alaltăieri o probă despre gradul si talentul actorilor nostri, nu mai puțin traducătorului din limba franceză A. Vasiliu" [The performers of the drama of the famous author Shakespeare, called The M erchant of Venice (The Blood Bond) gave us yesterday a proof of the talent of our actors and of the translator from French A. Vasiliu]. Gazeta de M oldova 101 (20 December 1851), quoted in Burada (1975, $341)$. Note that Shakespeare's play is referred to with both titles, the original title and the alternative title of the French adaptation.
} 
prestige of French, the Romanian public fully adopted the French domestication of the sources and credited the respective re-writings as representative of the original.

The same French adaptation of Shakespeare's The M erchant of Venice was retranslated into Romanian for performances in Wallachia (also called Țara Românească), the southern Romanian Principality. The 1854 production of the play in Bucharest bears a slightly different title, Shylock evreul sau Învoiala de sînge [Shylock, the Jew or the Blood Bargain]. ${ }^{9}$ This time, the translation, available in manuscript form, mentions not only the Romanian translator (A. Teulescu), but also the French author of the adaptation: Mr. D'Alboaz. The name "D'Alboaz," however, is misleading, as it is a conflation of the names of the two French authors of the adaptation, M. Du Lac and Jules-Edmond Alboise.

Romanian scholarship has largely ignored this version, first because it is an adaptation and secondly because it was impossible to identify the French source text. I. Horia Radulescu was the first critic to mention it. He discussed six early nineteenth-century Frenchbased Romanian translations of Shakespeare, tracing and comparing their respective source texts, which he identified as subsequent revisions of Pierre Letourneur's eighteenth-century version. As he did not know the source text of Shylock, Radulescu only provided basic performance-related information (1938, 260.) Alexandru Duțu has been the first scholar to discover the manuscript in the library of the Academy in 1964. He no longer includes the text under the heading of translations of Shakespeare, but relegates it to Shakespeare "adaptations." As Duțu also takes at face value the supposed author's name of "D'Alboaz," the puzzle around the French source is not solved. The manuscript has not attracted any further critical attention, mostly due to its low status as a translation of an adaptation. ${ }^{10}$

What is further intriguing about the manuscript version is the fact that it does not mention where the French text was first performed.

\footnotetext{
${ }^{9} \mathrm{~N}$ ot unlike many translations commissioned for the stage throughout the nineteenth and twentieth century, the only extant manuscript, surviving in the Library of the Romanian Academy, has never been published.

${ }^{10}$ I would like to mention the important help Fernando Cioni gave me in identifying the French adaptation which helped me find the two authors.
} 
By contrast, the French original, published in Paris in 1830, does provide a whole list of details missing in the Romanian translation: it specifies that the play is a drama (not a comedy); that it has three acts (the usual structure of melodramas) and that it was performed at Le Théâtre de la Porte Saint Martin in April 1830. Though the Romanian translation follows the original in a most faithful way, it omits this important information. It might be assumed that these data were not considered relevant to Romanian audiences, not even to the censorship committee inspecting the text in 1854, at a time of political unrest at the height of the Crimean War. ${ }^{11}$ However, there is plenty of evidence to suggest a different hypothesis. Romanian theater producers were eager to advertise the initial place of performance of a play, as its restaging also involved a transfer of cultural capital associated with the initial theater. Furthermore, the Romanian public was well familiar with the theater of Porte Saint Martin, holding it in greater regard than the Comédie Fran çaise, which was thought to be ossified and outmoded. ${ }^{12}$ Actors would regularly buy play texts of the performances staged there, convinced they would succeed in Romanian theaters (Ollanescu 1981, 231). Both actors and audience were equally aware of the involvement of this theater not only in the artistic revolution of the Romantics but also in the political events of the 1830 July Revolution and later on in the 1848 events. $^{13}$ Therefore, the omission of the name of the French theater and the conflation of the authors' names might well have been a deliberate ruse to hoodwink the censors, known to suppress anything associated with political protest.

Nevertheless, the fuzziness around the title and authorship of the play begs the question about the knowledge that the Romanian audience had of Shakespeare at the time of his introduction onto the Romanian stage. How much of a canonical author was Shakespeare considered? How well known were his plays? Did the Shakespeare bardolatry precede knowledge of his plays, as had been the case in Hungary? (Davidházi 1993; 1998). What were the consequences of the French mediation for the early reception of Shakespeare in this

\footnotetext{
${ }^{11}$ For detailed information on how the censorship in the theater worked at that time, see Radulescu (1935, 42-44).

${ }^{12}$ See note 22 below.

${ }^{13} \mathrm{M}$ any members of the audience had spent their student days in Paris at the time and even actively participated in the revolutionary events.
} 
part of Europe? To answer some of these questions, I will first look at the early material traces of Shakespeare's works in the two Romanian Principalities. Next, I will take up the discussion of the French adaptation of The $M$ erchant of $V$ enice and look into the reasons it resonated with the Romanian public twenty-five years after its first performance in Paris. Particular attention will be paid to the melodramatic reworking that Shakespeare's play underwent in French. Did this mediation impede or facilitate the early Romanian reception of Shakespeare?

\section{Shakespeare's early routes of entry into the Romanian Principalities}

The first important shipments of Shakespeare's works in German and French translation into this part of Europe took place in 1840 and were ordered by two major book stores, Bell and Henning, located in Iaşi. The records show that earlier on, in 1838, Adolf Henning, a teacher of German at an elite school in Iaşi ("Institutul de baieti de pe dealul Miroslavei") had ordered several copies of Shakespeare's "Werke" in the Schlegel and Tieck translation for his students (Ionita 2007, 112). In 1841, a shipment of plays by Victor Hugo, Dumas, and Casimir Delavigne also included Ducis's works (I onita 2007, 157). Given the late arrival of the Ducis imitations to the Romanian Principalities, at a time when the reaction of the French romantics against Ducis and the neoclassical theater had already been embraced in Romania, Ducis's imitations of Shakespeare had little resonance with the public. Further shipments of Ducis's versions were discontinued after 1842. Instead, there was a sudden demand for Shakespeare, with several shipments of his works in French being registered with both book vendors, Bell and Henning. Over the next years, the import of Shakespeare's plays in both French and German continued at an increasing pace (Ionita 2007, $104,112,119,130)$. Unfortunately, similar data are unavailable on the import of Shakespeare books to Bucharest, but the pattern of importing Shakespearean texts must have been similar. There is one difference, however: Tara Romaneasca was almost exclusively a francophone country, with only few German books imported here. No German book was reviewed in the major journals of the time. Consequently, we can safely infer that fewer editions of Shakespeare in German were circulated here than were in Moldova. 
Operatic adaptations provided another venue for the introduction of Shakespeare to the Romanian audience. ${ }^{14}$ The archives of the year 1840, when the first important shipment of Shakespeare's plays took place, also include an invoice for Rossini's opera Otello in French. By this date foreign opera troupes (with German, Italian or French singers) along with French and German theater troupes had become hugely fashionable and were generously financed by the authorities; in stark contrast, the newly established Romanian theaters were left unfunded. Though accused of impeding the development of the local Romanian theater, foreign troupes played an important role as transnational agents disseminating Western culture in Europe's borderland. ${ }^{15}$ The success of the 1842 performances in French of Rossini's 0 tello and of Bellini's Capuleti et $M$ ontecchi stimulated the audience's interest in Shakespeare and created a market for his plays. It probably determined an increase in the orders for Shakespeare's works in French translation the same year as well. Furthermore, the operatic performances can be said to have precipitated the translation of 0 thello and Romeo and Juliet through Letourneur's French versions and their publication in $1848 .^{16}$

One reason for the success of the operatic versions of Shakespeare's plays lies in the high status that the opera enjoyed at the time. ${ }^{17}$ Romanian audiences enthusiastically embraced the Italian

\footnotetext{
${ }^{14}$ For the relationship between opera, melodramatic adaptations and Shakespeare, see Sanders (2012, 188-97).

${ }^{15}$ The first Italian opera was set up in Moldova in 1837. A highly successful opera troupe was directed by the German soprano Henriette Karl, who used to sing at the Prussian court, another by the Greek manager Papanicola who had set up the first opera in Istanbul. Sometimes French troupes would not come down from Paris but from Odessa, Russia, thereby setting up an Eastern European connection (Burada 1975, 129). On foreign companies in the Romanian Principalities in the early nineteenth century and on the cosmopolitan audience they played for, see Ollanescu (1981, 240-43), Burada (1975, 350-59), and Boia (2015, 19).

${ }^{16}$ Letourneur was known to the Romanian public from his translations of Young's poems, which were initially as popular as Byron's.

17 There was a craze for the Italian opera in all the important cities of the two principalities, including provincial cities like Craiova and Pitesti. All of the works of Rossini, Bellini, Donizetti, Karl Maria von Weber, Verdi and later on Wagner were performed in Italian, French or German. Authorities strongly subsidized and encouraged foreign opera companies who were eager to bring celebrities to this part of the world. (Liszt came in 1846, A dela Ristori in the early 1860s, etc.).
} 
opera as an emblem of their radical break with the Ottoman traditions and as an icon of their new affiliation with European modernity. Translations into Romanian of opera librettos, including of course Rossini's 0 tello, were a big market success in the $1850 \mathrm{~s}$ (Cornea 1966, 55-58). The Romanian passion for Rossini's Otello lasted until the 1870s, when Salvini's and Rossi's performances of Shakespeare's 0thello reoriented the public's interest towards Shakespeare's play. In 1845, before the publication of the first Romanian translation of 0 thello, the bulk of the Romanian public was familiar only with Rossini's version of the story. Even theater critic and dramatist Cezar Bolliac wrote a detailed review of a performance of the opera in Bucharest and mentioned Shakespeare only in passing, as a rewriter of Cinthio (Bolliac 1836). Although Bolliac was the first Romanian critic to write an essay on Shakespeare in 1836 (Bolliac 1836; Grigorescu 1971, 4), his knowledge of the plays was rather derivative and his essay largely reproduced Hugo's views on Shakespeare's genius as expressed in the preface to Cromwell. In conclusion, the opera can be said to have lent prestige and popularity to Shakespeare's plays.

For all the huge prestige that Hugo enjoyed in the Romanian Principalities at the time, ${ }^{18}$ his exalted views on Shakespeare did not play an important role in Romanian literary life. ${ }^{19}$ Shakespeare was only named once, in a sequence of authors that starts with Schiller. While Romanian writers were enthusiastic supporters of Hugo, Dumas and Delavigne and of their defeat of the neoclassic tradition, ${ }^{20}$ the use of Shakespeare in this clash did not have any

${ }^{18}$ Almost all of Hugo's plays were translated and performed in the 1840 s and $1850 \mathrm{~s}$ (Petrea 45, 159).

${ }^{19}$ Surprisingly, the preface to Cromwell was neither translated into Romanian nor discussed in literary debates. Likewise, the battle of H ernani, i.e. the dispute between the two literary camps in France in which Hugo had mobilized Shakespeare's example, did not have any resonance with Romanian writers (Cornea 2008, 227).

20 “Pe ideea asta, o gloată de scriitori a năbușit pe scena Frantii, au introdus pe teatru sistema lui Sakispir, Ghete si Siler. Dar nu tuturora le e dat sa scrie ca Sakispir sau Siler [...] si opintirile lor n-au făcut decit sa strălucească adevarații poeți si scriitori precum Hugo, Delavigne, Dumas. Aceștia înțelegînd duhul parterului ce se săturase de tragediile înalțate ale lui Corneil, elegiacice ale lui Rasin si filozofice ale lui Volter, și-au croit o sistemă mai potrivită pentru veacul lor [...]" [Working on this idea, a band of writers have flooded the French stages and have introduced into the theater the system of Shakespeare, Goethe and Schiller. But not everybody has the gift to write like Shakespeare and Schiller [...] and their stumbling and fumbling have set off 
particular resonance in Romanian cultural life. The Romanian Romantic Movement did not emerge in a conflict against the norms and values of the Enlightenment nor could the figure of Shakespeare be enlisted in any cultural or political struggle, the way he was deployed in other parts of Europe. Consequently, he got relatively glossed over. He was an "other," placed at a double remove from Romanian culture. His reception needed heavy mediation via more familiar theatrical genres.

\section{The appeal of the melodramatic version of The Merchant of Venice}

Why did the Romanian actors, going to Paris in the early 1850 s to get updated on the latest theatrical hits, accept an adaptation of The $M$ erchant of $V$ enice that had been staged twenty years before? Why did they choose an adaptation and not a more "faithful" and prestigious translation of Shakespeare such as Alfred de Vigny's The $M$ erchant of V enice (1827) or his 0 thello (1829)?

One obvious reason is that the Romanian actors were more interested in the popular performances on the Boulevard stages, where Shakespeare was present, albeit in heavily appropriated and re-written versions that sometimes bore little resemblance to the original (Pemble 2005, 98-100). ${ }^{21}$ Théophile Gautier was critical of these frivolous "imitations," which both grossly domesticated Shakespeare and further combined him with material drawn from Gothic writers, such as Ann Radcliffe and Lewis (Gautier 1859, 19; Pemble 2005, 101; Clark-Wehinger 2005, 67). Gérard de Nerval particularly objected to such eclecticism, fearing that the vulgarization of Shakespeare in the popular "imitations" might

the quality of true poets and writers like Hugo, Delavigne, Dumas. These, having understood that the spirit of the parterre has got tired of the elevated tragedies like Corneille's, or the elegiac ones of Racine, or the philosophical ones of Voltaire, have fashioned a new system, better suited to their age] (Negruzzi 1986, 514-15).

${ }^{21}$ Not all French critics were fully aware of the difference between the "faithful" versions (still heavily purged and re-written to suit the French taste) and the mere "imitations." Thus Le Figaro of A pril 201830 cannot distinguish between De Vigny's "faithful" translation for the stage and Du Lac and Alboise radical re-writing of The M erchant of V enice (Bassan 1984, 41). For the French tendency to take adaptations as representative of the original Shakespearean play see Morse $(2004,113)$. 
undermine the Romantic reformation of the French theater that had taken Shakespeare for its model (Clark-Wehinger 2005, 97, 131).

The Shylock staged at Le Théâtre de la Porte de Saint Martin provided an instance of the eclecticism which the French literary circles objected to, as it combined the Shakespearean plot with fashionable elements of the "drame sociale," the three unities of the French classic theater, plus some Gothic violence in the ending. Nerval dismissed the Shylock figure, who does get his pound of flesh in the end, "as a caricature of Shakespeare's character, ruled merely by passions and instinct" (Clark-Wehinger 2005, 98). The performance, however, proved successful and was staged in France well into the $1840 \mathrm{~s}^{22}$

I would like to advance three reasons that might have prompted the Romanian actors to choose this Shakespearean adaptation over other more "faithful" versions, which enjoyed the critics' support. To begin with, it is a prose translation; secondly, it has the appeal of the melodrama, thus ensuring a quick box office success; and thirdly, it could mobilize revolutionary meanings on the Romanian stages.

Du Lac and Alboise's prose version was easier to translate than a more "faithful" translation in verse, such as de Vigny's Le M archand de $V$ enise. The Romanian language was still in the early stages of modernization and hardly lent itself to the translation of French alexandrines. The 1855 translation of Dumas's version of $\mathrm{H}$ amlet in verse proved a disaster and compromised the performance of a most expected play. At the same time, Romanian translators had already acquired significant experience translating the colloquial prose of melodramas.

The melodramatic format must have appealed to the actors since they were aware that this highly emotional style was essential for the survival of the newly established theaters in the Romanian Principalities, where melodrama had strong appeal, and would ensure the allegiance of a large and varied audience. The clichés of the genre, much maligned by literary critics, nonetheless facilitated cultural adaptation and absorption of Western into Eastern culture.

${ }^{22}$ An important key to its success was the spirited performance of Shylock's role by Bocage, one of the most important and innovating actors of the Boulevard theaters, who could masterfully combine the old declamatory style with the new "natural acting," learned from the English players. 
Romanian theaters were particularly receptive to the second wave of melodramas written in the late 1920's and '30's by Victor Ducange and his school. ${ }^{23}$ These plays tried to occupy a middle ground between the "classic" type that emerged in postrevolutionary France and a more temperate approach that recuperated themes of the Enlightenment related to social and political issues, such as tolerance, justice, opposition to tyranny. ${ }^{24}$ This type of drama fits well with the "half romantic" nature of the Romanian literature in the 1830-1860 period, where features of the Enlightenment and Romanticism coexisted and interacted, both being regarded as revolutionary departures from the dominant traditions (Nemoianu 1984, 125-26). Romanian theater professionals and public alike appreciated the political and civic potential of these "liberal" melodramas and lumped them together with Romantic prose dramas by Hugo and Dumas, all initially performed at the theater of La Porte de Saint Martin in the $1830 \mathrm{~s}^{25}$

One more reason for the appeal of melodrama to the Romanian public was the conservative patriarchal values enshrined by the style (Przybos 1987). These values were in consonance with the views embraced in the Romanian society of the time and provided a common ground for the otherwise diverging French and Romanian social realities. The melodramatic adaptation of The $M$ erchant of $\checkmark$ enice applied a radical re-writing of the moral make-up of Bassanio and Portia. The latter, renamed Nerissa, is no longer a wealthy heiress, but a destitute poetess who lacks the money to bury her mother. Portia alias Nerissa does not disguise herself and therefore does not transgress against the traditional gender roles which had been reinforced by the French Restauration. ${ }^{26}$ She still wields a controversially strong power as a popular poetess, who can

\footnotetext{
${ }^{23}$ For the importance of distinguishing between various types of melodrama and the changes it underwent, see Thomasseau (2009). British critics have been mostly interested in the earlier, "classic" melodrama which emerged in the postrevolutionary years and was exported to Britain in the Napoleonic period (Cox 2007; Moody 2004; Bratton 2007).

${ }^{24}$ Relatively little has been written on the "second wave" of melodramas and its social oriented character; for best analyses see Thomasseau (2009), and Le Hir (1992).

${ }^{25}$ On the hybridization of melodramas and the Romantic drama of Hugo and Dumas, see Le Hir (1992, 125-29) and Cooper (2005, 456-63).

${ }^{26}$ Melodramas promoted the reinforcement of traditional definitions of femininity that was predicated on women's dependence on the husband and father (Perrot 1994).
} 
manipulate the "people" into rebelling against the Duke. Bassanio is Antonio's son (Antonio is the arch-villain in the play, yet does not appear on the stage); he is no longer the profligate wooer but Portia's/ Nerissa's secret financial supporter who asks Shylock for a loan to help her out. In a typically melodramatic manner, the adaptation suppresses the complex interlocking between commerce and romance in Shakespeare's play and rewrites the heroes as unambiguously virtuous victims. Bassanio adopts the sacrificial position of a Christ-like figure: he and not Shylock is the one who suggests the blood deal and offers his own piece of flesh as a warrant.

Family values are further reinforced; Shylock is a most loving father, not short on sympathy and fellow-feeling ${ }^{27}$ and initially forgives his daughter's transgressive feelings towards a Christian. Jessica is not a rebel and reciprocates her father's love with filial piety: she does not actually consent to her elopement and has to be abducted. Jessica attends the trial in order to defend her father and places herself between him and the enraged people.

The choice of an older version of the play over a more fashionable one could further be explained from a political perspective. Paris was a fascinating cultural capital for the Romanian intelligentsia on account of the combination of the political and artistic emancipation they found there. Romanian actors identified this political edge in the plays of the 1830s, staged around the July revolution, rather than in the repertoires of the late 1840s. It was in that earlier period that the relation between Romanticism and revolution was established in the theater. As Anne Ubersfeld $(1968,20)$ has pointed out, to be a Romantic meant to be against the government-in particular, to be against its fierce political and cultural censorship. Boulevard theaters -one of them being Le Théâtre de la Porte Saint Martin, where Shylock was performed-became hot spots in the July Revolution, with theater people fighting on the barricades (Duby and A riès 1994, 462).

${ }^{27}$ In the first act, several poor people praise his acts of charity and project him as a Robin Hood figure who rips off the rich to help the poor: "Le jeune pauvre: Oui, Shylock est dur aux riches, mail il est bon, humain pour nous" (Du Lac and Alboise 1830, 2; my emphasis). 
The Shylock of this version is reconfigured as a spokesman of the Droits de I'Homme and of the great ideals of the 1789 French Revolution of égalité fraternité- liberté. He confesses to his daughter early in the play:

J'étais né avec une âme tendre et généreuse [...] et le juif comme le chrétien était un frère à mes yeux; [...] je croyais qu'une âme grande, une figure humaine me rendait l'égal des autres hommes; je ne savais pas que le titre d'esclave était attaché aux vêtements de ma nation. (Du Lac and Alboise, 1830; 14; my translation and my emphasis)

[I was born with a loving and generous soul [...] and the Jew just like the Christian was a brother to me [...] I believed that a large soul and a human appearance would render me the equal of other men; I did not know that the label "slave" had been attached to the clothes of my nation.]

Shylock's thirst for revenge is further re-designed in keeping with the notion in the Declaration of the right to resistance and to redress for injury, notions which Benjamin Constant further developed. ${ }^{28}$

What is particularly interesting about this adaptation is that Shylock's personal action of revenge is coupled with a more impersonal legal initiative. He proposes to the Jewish community to use their financial clout and oblige the Duke and the senate to pass a law that secures what the French text calls "Ies franchises de notre nation" [the rights/ freedoms of our nation]. Du Lac and Alboise conflate here the two Venetian outsiders-Othello and Shylock. ${ }^{29}$ Shylock finds himself in the position of being asked to save the Venetian state not militarily but financially. The play expands the suggestion in Shakespeare's play of an alternative civic community around the synagogue (Lupton 2005) and introduces a council of the Jewish community which debates the loan to be granted to the state. In a most unexpected strategy of turning tables and propelling the underdog into a position of power, Du Lac and Alboise have the Duke come to the Jewish council to beg for assistance. Shylock, as leader of his community, proposes that in exchange of the loan given to Venice, the Jewish community should ask for the adoption of a

\footnotetext{
${ }^{28}$ I have discussed this aspect at large ( $\mathrm{Nicolaescu} 2011$ ).

${ }^{29}$ For the discussion of similar conflations of Othello and Shylock, see Bassi $(2011,239$ 42).
} 
new law that would secure their rights to equal and nondiscriminating treatment and to the inviolability of property:

[...] le ciel remet encore une fois le destin de Venise en nos mains.

Ces patriciens si fiers, ce sénat si superbe, le doge lui-même implorent aujourd'hui notre appui. Esclaves soumis, hier nous courbions humblement nos fronts devant eux. Les rôles ont changé. Ce sont les maîtres qui prient maintenant, et qui attendent avec anxiété que nous leur tendions une main secourable. Que faut-il faire? Laisser consommer leur ruine, et fuir avec nos trésors loin d'un pays où chacun de nos services est payé par une persécution nouvelle, ou bien oublier le passé, les sauver encore, mais en assurant cette fois et pour toujours les franchises de notre nation! Parlez, mes frères, que décidez vous?

[The heavens have once again put the fate of Venice into our hands. These proud patricians, this great senate, the doge himself beg us to come to their help. Yesterday we were still humble slaves who bowed down before them, today the roles have changed. Now the masters beg us and wait anxiously for us to give them a helping hand. What shall we do? Shall we let them be ruined and run away with our fortunes far away from a country where our charitable acts are rewarded with renewed persecutions, or shall we forget the past, forgive them, yet this time take action to secure once and for all the freedoms/rights of our nation? Say brethren, what is your decision?] (Du Lac and Alboise, 1830, 5-51; my translation and my emphasis)

It is beyond doubt that the French political reconfiguration of Shylock must have appealed to the Romanian theater people during the Russian occupation in the early 1850s. Shylock is hardly identified with the Jewish minority in the Romanian Principalities, whose numbers were just beginning to grow and became a target of anti-Semitic feelings. The Shylock of this version is read as a champion for equality and democratic rights and as such shares many features with the revolutionaries of the generation of FortyEight. In this period, the "Forty-Eighters" (i.e. the participants in the 1848 Revolution) at home and in exile were organizing a follow-up to the action of national and political liberation initiated in 1848. The revolutionaries were determined to use the Crimean War for the opportunities it opened up to liberate the country from the Russian protectorate and to negotiate a greater autonomy from the Ottoman Empire. The revolutionaries' agenda further included the recognition by the Sublime Porte of a new republican government 
and the extension of political rights and liberties granted to the Romanian population. In spring 1854 there broke out a series of uprisings against the Russians (the "barbarians from the North") (Barbu 2003, 11); an army in the southern part of the country had been organized and a republican government was in the making. The revolutionaries' plans fell through when Austria invaded the country and made a separate settlement with the Ottoman Empire. Given this political context, Shylock's active stance and refusal to bow down to oppression in Du Lac and Alboise's adaptation must have resonated deeply with the Romanian audience.

The Romanian translation of "les franchises de notre nation" introduced a slight change that pointed directly to the local political events. The word "franchises" is translated with "eliberare"meaning not merely freedoms/ rights but "liberation." This coincides with the fact that at that time the new revolutionary government and General Magheru, who was in charge of organizing the military insurrection, had advanced "a new Constitution of the Romanian Principalities, drawn up on the basis of the desires of the Romanian people, the progress of time and the security of the Ottoman Empire" (Barbu 2003, 76). The similarity between the two proposals must have had a titillating impact on the Romanian audience.

The translation of the play smuggled onto the Romanian stage a rich human rights vocabulary. References to equality, the rights of the individual, protection against unjust laws, as well as legal terms like contract, convention, warrant, not only supplied a "foreignizing" effect (Venuti 1995) but also conveyed an indirect political statement in favor of reform and modernization. The success of the first production of a Shakespearean play on the Romanian stages was therefore less indebted to the prestige of the Bard and more to the innovative cultural and political transfer that the radical French adaptation performed on the Romanian stage.

To conclude: this paper has been discussing the French route of Shakespeare's circulation across Europe to its south-eastern border. Contact with Shakespeare occurred later here than in Central Europe or Russia and coincided with the dissemination of Romantic French theater and Italian opera. What was first performed in Bucharest was a French melodramatic re-writing that radically reconfigured both the plot and the Shylock figure. I have been trying to argue that it is this very re-writing, taken as representative of the original, which 
best fitted the cultural and political context of a Shakespeare performance in a part of Europe that was trying to free itself both from the Russian occupation and the Ottoman rule. Given the heavy mediation of the Shakespearean play, what was mostly transferred to the Romanian stage had less to do with Shakespeare's England and much more with modern nineteenth-century French culture.

\section{References}

Barbu, Paul Emanoil. 2003. "Studiu introductiv." In Actiuni sociale si politice romanesti in anii 1853-1854 [Romanian Social and Political Documents in the Years 1853-1854], 5-25. Bucuresti: Editura A cademiei Romane.

Bassan, Fernande. 1984. Alfred de Vigny et la ComédieF rançaise. Tübingen and Paris: Gunter Narr Verlag and Editions Jean Michel Place.

Bassi, Shaul. 2011. "Barefoot to Palestine: The Failed Meetings of Shylock and Othello." In V isions of Venice in Shakespeare, edited by Laura Tossi and Shaul Bassi, 231-50. Farnham and Burlington: Ashgate.

Boia, Lucian. 2015. Cum s-a românizat România [How did Romania get Romanian.] Bucuresti: Humanitas.

Bolliac, Cezar. 1836. "Sakespir." Curiosul. 1: 30-31.

Bratton, Jacky. 2007. "Romantic Melodrama." In The Cambridge Companion to British Theatre 1730-1830, edited by Jane Moody, and Daniel Quinn, 11527. Cambridge: Cambridge University Press.

Burada, Teodor T. 1975. Istoria Teatrului in M oldova [History of the Theater in Moldavia]. New edition. Bucuresti: Minerva.

Clark-Wehinger, Alice. 2005. William Shakespeare et Gérard de N erval: Le thêâtre romantique en crise, 1830-1844. Paris: Harmattan.

Cooper, Barbara T. 2005. "French Romantic Tragedy." In A Companion to Tragedy, edited by Rebecca Bushnell, 452-68. Oxford: Blackwell.

Cornea, Paul. 1966. D e la A lecsandrescu la Eminescu, aspecte, figuri, idei. [From Alecsandri to Eminescu, Aspects, Figures, Ideas] Bucuresti: Editura Pentru Literatură.

- - . 2008. O riginile romantismului românesc [The Origins of Romanian Romanticism], $2^{\text {nd }}$ edition, Bucuresti: Polirom.

Cox, Jeffrey N. 2007. "The Death of Tragedy; or the Birth of M elodrama." In The Performing Century. Nineteenth Century Theatre's History, edited by Tracy C. Davis, and Peter Holland, 161-81. Basingstoke: PalgraveMacMillan. 
Nicolaescu

D'Alboaz. 1854. Seilok evreul sau invoiala de singe. D rama in 4 acte. A. Teulescu, trans. The Library of the Romanian A cademy. MS. 5864.

Davidházi, Péter. 1993. "Providing Texts for a Literary Cult. Early Translations of Shakespeare in Hungary." In European Shakespeares. Translating Shakespeare in the Romantic A ge, edited by Dirk Delabastita, and Lieven D'Hulst. 147-62. A msterdam/ Philadelphia: John Benjamins.

- - - 1998. The Romantic Cult of Shakespeare: Literary Reception in Anthropological Perspective. London: Palgrave Macmillan.

Drace-Francis, Alex. 2006. The M aking of M odern Romanian Culture. Literacy and the Development of $\mathrm{N}$ ational Identity. London and New York: I.B. Tauris.

Du Lac, M. and Alboise, Jules-Edmond. 1830. Shylock, drame en trois actes, imité de Shakespeare. Paris: Bezou.

Duby, George, and Philippe Ariès, eds. 1985-1987. H istoire de la vie privée. V ol 4. De la Révolution à la Grande guerre. Paris: Seuil.

Duțu, Alexandru. 1964. Shakespeare in Rumania. A Bibliographical Essay. Bucuresti: Meridiane.

Espagne, Michele. 2013. "La notion de transfert culturel." Revue Sciences/ Lettres 1. Accessed May 30, 2017. DOI: 10.4000/ rsl.219.

Gautier, Théophile. 1859. “De l'état actuel du théâtre." In H istoire de l'art dramatique depuis vingt-cinq ans. Vol 1, 15-20. Paris: Editions Hetzel.

Gibińska, Marta. "Polonia est divisa in partes tres: Shakespeare in the Polish culture of the 19th Century." In "In double trust": Shakespeare in Central Europe, edited by Jana Bžochová-Wild, 7-28. Bratislava: VŠMU, 2014.

Grigorescu, Dan. 1971. Shakespeare in cultura romana moderna. Bucuresti: Minerva.

Grimm, Petre. 2012. Scrieri de istorie literara [Writing of Literary History]. Edited by Liana Muthu. Cluj: Eikon Scriptor.

Hugo, Victor. 1968. “Préface" Cromwell. 62-108. Paris: Flammarion.

Ionita, Alexandra. 2007. Carte franceza in M oldova pana la 1859 [French Books in Moldova until 1859]. Iaşi: Demiurg.

Lambert, José. 1993. "Shakespeare en France au tournant du XVIIle siècle. Un dossier européen." In European Shakespeares. Translating Shakespeare in the Romantic A ge, edited by Dirk Delabatista, and Lieven D'Hulst, 22-45. Amsterdam/ Philadel phia: John Benjamins.

Le Hir, Marie-Pierre. 1992. Le Romantisme aux enchères: Ducange, Pixérécourt, Hugo. Amsterdam: John Benjamins.

Lupton, Julia Reinhard. 2005. Citizens-Saints. Shakespeare and Political Theology. Chicago: Chicago University Press. 
Mayer, David. 2004. "Encountering Melodrama." In The Cambridge Companion to Victorian and Edwardian Theatre, edited by Kerry Powell. 145-64. Cambridge: Cambridge University Press.

Minier, Marta. 2014. "Uprooting Shakespeare. A Historical Survey of Early to Institutionalised Hungarian Shakespeare Translation." In "In double trust": Shakespeare in Central Europe, edited by Jana Bžochová-Wild, 2951. Bratislava: VŠMU.

Moody, Jane. 2004. “The Theatrical Revolution, 1776-1843." In The Cambridge History of British Theatre. Vol. 2: 1660-1895, edited by Joseph Donohue, 199-216. Cambridge: Cambridge University Press.

Morse, Ruth. 2004. "Monsieur Macbeth: from Jarry to Ionesco." Shakespeare Survey 57: 112-25.

Negruzzi, Costache. 1986. Teatru, vol 3. Edited by Liviu Leonte. Bucuresti: Minerva.

Nemoianu, Virgil. 1984. The Taming of Romanticism. European Literature and the A ge of Biedermeier. Boston: Harvard University Press.

Nicolaescu, Madalina. 2011. "Re-writing Venice and Radicalizing Shylock: Nineteenth-Century French and Romanian Adaptations." In V isions of Venice in Shakespeare, edited by Laura Tossi and Shaul Bassi, 215-31. Farnham and Burlington: A shgate.

- - . "Shakespeare in Habsburg Transylvania." In Renaissance Shakespeares: Shakespeare Renaissances. Proceedings of the Ninth World Shakespeare Congress, edited by Martin Prochaska, Michael Dobson, Andreas Hoefele, 211-19. N ewark: University of Delaware Press, 2014.

Ollanescu, C. Dimitrie. 1981. T eatrul la romani [Romanian Theater]. Edited by Cristina Dumitrescu. Bucuresti: Editura Eminescu.

Pemble, John. 2005. Shakespeare Goes to Paris. How the Bard Conquered France. London and New York: Hambledon and London.

Perrot, Michelle. 1987. "La Famille triomphante." In Histoire de la vie privée. Vol 4. De la Révolution à la Grande guerre, edited by Philippe A riès and George Duby, 93-103. Paris: Seuil.

Petrea, Elena. 2009. V ictor Hugo in cultura româna. Iasi: Editura Universitatii Alexandru Ioan Cuza.

Przybos, Julia. 1987. L'entreprise mél odramatique. Paris: Jose Corti.

Radulescu, Ion Horia. 1935. Contributiuni la istoria teatrului din Muntenia 1833-1853. [Contributions to the History of the Theater in Muntenia]. Bucuresti: Institutul de Istorie Literara si Folclor.

- - - 1938. "Les intermédiaires français de Shakespeare en Roumanie." Revue de littérature comparée 18: 252-71. 
Nicolaescu

Sanders, Julie. 2012. "Shakespeare and Music." In Shakespeare in the Nineteenth Century, edited by Gail Marshall, 187-205. Cambridge: Cambridge University Press.

Schulze, Brigitte. 1993. "Shakespeare's Way into the West Slavic Literatures and Cultures." In European Shakespeares: Translating Shakespeare in the Romantic Age, edited by Dirk Delabastita and Lieven D'Hulst, 55-74. Amsterdam: John Benjamins.

Shakespeare, William. 1996. The M erchant of Venice. Edited by Molly Maureen Mahood. Cambridge: Cambridge University Press.

Stokes, John. 2012. "Shakespeare in Europe." In Shakespeare in the N in eteenth Century, edited by Gail Marshall, 296-314. Cambridge: Cambridge University Press.

Thomasseau, Jean-Marie. 2009. M élodramatiques. Saint Denis: Presses Universitai res de Vincennes.

Ubersfeld, Anne. 1968. Introduction to "Préface" Cromwell, by Victor Hugo. 17-51. Paris: Flammarion.

Venuti, Lawrence. The Translator's Invisibility: A History of Translation. London and New York: Routledge, 1995.

Vigny, Alfred de. 1920. Théâtre. Vol 2. Paris: Flammarion. (Le More de Venise 31-219: Le Marchande de Venise 219-324).

Willems, Michele. 2010. “Voltaire." In V oltaire, Goethe, Schlegel, Coleridge Great Shakespeareans, vol. III, edited by Roger Paulin, 5-44. London: Bloomsbury.

\footnotetext{
How to cite this article:

Nicolaescu, Madalina. "Introducing Shakespeare to the fringes of Europe: The first Romanian performance of The M erchant of V enice." SED ERI 27 (2017): 129-48.

A uthor's contact: madalinanicolaescu@gmail.com

Postal address: English Department - University of Bucharest - Str Pitar Mos 7-10 Bucuresti 990023, Romania
} 


\title{
Perceptions of sister queens: A comparison of printed book dedications to $M$ ary and Elizabeth Tudor
}

\author{
Valerie Schutte \\ Independent Scholar
}

\begin{abstract}
Comparisons of Mary and Elizabeth Tudor, sister queens of England, have become popular in the last decade as scholars have realized the impact of Mary on Elizabeth's queenship. To further that comparison, this essay likens printed book dedications to Mary and Elizabeth before each woman became queen and during their first five (or only five) years as queens. This essay argues that dedications to the Tudor sister queens show that these two women were perceived more commonly than has previously been recognized. By exploring these book dedications, it becomes evident that dedications were central to contemporary perceptions of what authors and translators thought Mary and Elizabeth would be interested in reading and passing along to their subjects along with what dedications thought the sister queens should be reading so as to be persuaded in different directions.

KEYWORDS: Queen Mary I; Queen Elizabeth I; Tudor; book dedications; John Proctor; John Foxe; Laurence Humphrey.

\section{Percepciones de las reinas hermanas: una comparación de dedicatorias a \\ M ary y Elizabeth Tudor en los libros impresos*}

RESUMEN : Las comparaciones entre Mary y Elizabeth Tudor, hermanas y reinas de Inglaterra, se han popularizado en la última década a medida que los investigadores se han dado cuenta del impacto de Mary en el reinado de Elizabeth. Para llevar esa comparación aún más lejos, este artículo equipara las dedicatorias a Mary y a Elizabeth incluidas en libros impresos antes de que se convirtieran en reinas y durante sus primeros cinco años de reinado. El presente trabajo sostiene que

Perceções de rainhas irmãs: uma comparação de dedicatórias a $M$ ary e Elizabeth Tudor em livros impressos ${ }^{* *}$

RESUMO: Mary e Elizabeth Tudor, rainhas irmãs de Inglaterra, tornaram-se populares na última década à medida que os estudiosos têm vindo a entender o impacto de Mary no reinado de Elizabeth. De modo a aprofundar essa comparação, este ensaio confronta dedicatórias a Mary e a Elizabeth em livros impressos antes de cada uma se tornar rainha assim como durante os primeiros cinco anos (ou nos únicos cinco anos) do reinado de cada uma. Este ensaio argumenta que as dedi-
\end{abstract}

\footnotetext{
*Translation into Spanish by Tamara Pérez-Fernández

** Translation into Portuguese by Miguel Ramal hete.
} 
las dedicatorias a las hermanas y reinas Tudor demuestran que estas dos mujeres fueron percibidas de forma más cercana de lo que previamente se había pensado. Con este análisis se hace evidente que estas dedicatorias fueron fundamentales en las percepciones contemporáneas de lo que autores y traductores pensaban que Mary y Elizabeth podrían estar interesadas en leer y en hacer circular entre sus súbditos, así como lo que las dedicatorias pensaban que las reinas hermanas deberían leer para inclinarlas en determinados sentidos.

PALABRAS CLAVE: Mary I; Elizabeth I; Tudor; dedicatorias en libros; John Proctor; John Foxe; Laurence Humphrey. catórias às rainhas irmãs Tudor mostram que estas duas mulheres eram entendidas de uma forma mais próxima do que o que se tem vindo a pensar. Ao explorar estas dedicatórias em livros, torna-se evidente que as dedicatórias ocupavam um lugar central nas perceções contemporâneas daquilo que autores e tradutores achavam que Mary e Elizabeth estariam interessadas em ler e em passar aos seus súbditos, assim como o que as dedicatórias consideravam dever ser lido pelas rainhas irmãs, de modo a serem persuadidas em diferentes direções.

PALAVRAS-CHAVE: Rainha Mary I; Rainha Elizabeth I; dedicatórias de livros; John Proctor; John Foxe; Laurence Humphrey.

I "exhort your grace to the continuance of your godly and vertuous liuing [...] and send your grace as it were an anker [...] least that your grace should (that God forbid) wauer or slide from the Catholike and true faith of God" (Hannapes 1561, C.iiii.v-C.v.r). Thomas Paynell wrote these words to Queen Elizabeth I in 1561, accompanying his translation of $\mathrm{Nicholas} \mathrm{de} \mathrm{Hannapes} \mathrm{The} \mathrm{en} \mathrm{samples}$ of vertue and vice. Paynell's dedication continued to praise Elizabeth's virtuous living as a model for other women. While his dedication to Elizabeth was just one of 183 printed book dedications that she received while she was queen, it is important for its resemblance to the dedications that Elizabeth's sister, Mary, received while she was queen. Paynell dedicated translations not only to Elizabeth and Mary, but also to their father, King Henry VIII (Moore 2011). As with Elizabeth, Paynell's dedications to Mary also advocated for Roman Catholicism while at the same time praised her wisdom and virtue. Superficially, dedications, such as those by Paynell, to Elizabeth and Mary followed similar rhetorical strategies, acknowledged that connection to a royal patron increased the authority of their texts, and offered some type of counsel to their dedicatees. Yet dedications to the sisters are important because they show that dedicators perceived the Tudor queens more similarly than has previously been recognized. 
This essay offers a comparison of the printed book dedications received by Mary and Elizabeth, of which those by Paynell are just a few. Specifically, I will briefly discuss pre-accession dedications to the sisters and focus the majority of the essay on all of the dedications given to Mary while she was queen and those to Elizabeth during the first five years in which she was queen, from November 1558 to 1563. This narrow frame of comparison is useful because during the first (or only) five years of each of their reigns, each queen faced similar challenges of obedience from their subjects, the state of church within England, and suitors and marriage, thereby providing the greatest similarities in purpose of dedicating to the Tudor queens. I will provide an overview of those similarities, such as counsel-giving and religion, as well as explaining one key difference: how dedicators perceived each queen to have influence over statecraft.

Comparisons of Mary and Elizabeth have only recently begun to be undertaken by scholars, and tend to focus on education, imagery, and ceremony, such as their coronation entry processions and how each woman touched for scrofula, but I suggest that book dedications are another area for comparison that have previously been under-utilized (Pollnitz 2015; Mclntosh 2009; Duncan 2011; Hunt and Whitelock 2010; Brogan 2015). Dedication comparison offers information regarding how authors and translators addressed each queen, offered them counsel, used textual imagery for both flattery and condemnation, used their names to increase book sales and influence, and in some cases how these sister queens negotiated with dedicators over patronage.

An examination of book dedications to Mary and Elizabeth also contributes to some of the newest emerging historiography of queenship, women's readership, and book creation. Over the last three decades, several scholars have undertaken to both categorize and explicate the relationships between women, reading, writing, textual reproduction (Hull 1982; Burke 2000; Erler 2002; Hannay 1985; Frye 2010; Goldsmith and Goodman 1995). However, the study of book dedications has only recently been taken seriously, instead of denigrated as praise that might not have reflected actual textual relationships (Wood 2008; Buchtel 2004; 2008; Baranda Leturio 2011; Guardiola-Griffiths 2011). Both Julia Crawford and Helen Smith have used book dedications to show that early modern books were 
collaborative efforts, and therefore consisted of more gendered interaction than has previously been recognized (Crawford 2014; Smith 2012). More specific to this essay, several recent studies have emerged that explicate dedications to Queen Mary I, yet they have focused on dedications to other royal women that mention Mary, a comparison of pre-accession dedications to Mary and Elizabeth, and a bibliographic analysis of all manuscript and printed book dedications to Mary (Schutte 2015; 2016; forthc.). This essay is in conversation with these studies, but adds to them by offering a comparison of specific elements of dedications to Mary and Elizabeth, such as counsel, to show that book dedications are overlooked sources that explain the process whereby a specific text was chosen for a specific dedicatee while at the same time offers insight into perceptions of that dedicatee. This essay contributes to furthering the understanding of ways in which Mary and Elizabeth were considered alike and how images of both women were proliferated by others, often without their knowledge or permission.

\section{D edications to the $Q$ ueens}

Before Mary and Elizabeth Tudor became queens of England, they each received a variety of printed book and manuscript dedications, as befitting their positions as daughters of and sisters to a king. Specifically, Mary received nineteen dedications and Elizabeth received seven, most likely because Mary was seventeen years older than Elizabeth and became queen at age 37 while Elizabeth inherited the throne at age 25 (Schutte 2015, 33-48; forthc.). Books on religion made up the majority of texts dedicated to Mary and Elizabeth, with those to Mary covering traditional, Catholic religion and those to Elizabeth addressing evangelical, reformed religion, showing that dedicators understood the differing religious views of the princesses. Dedicators were also aware that both princesses were highly educated and were prepared to contribute to their educations, with Elizabeth receiving dedications to two textbooks and Mary receiving three. Even though Mary and Elizabeth received preaccession dedications to similar types of books, the dedicators of those books perceived the princesses very differently. The difference in number of dedications to each princess, alone, suggests that Mary was perceived to be more important at court and have more patronage power than did her sister (Richards 2012, 194; Dowling 1986, 238). 
Dedications to the sisters before their accession to the throne demonstrate that Mary was regarded as an important figure, no matter her demoted status, while Elizabeth was often disregarded as a second daughter of the king, no matter her legal status.

As queen, Mary received twenty-five printed book dedications, while Elizabeth received fourteen in the first five years of her reign (Schutte 2015; Wood 2008). Each queen also received numerous manuscript dedications, most of which were given as New Year's gifts, as New Year's festivities were traditionally an occasion to give and receive gifts, thus providing the ideal opportunity to give the queen a present and receive something in return, such as a gift or patronage. ${ }^{1}$ The New Year's gift exchange allowed an opportunity for miscellaneous people with no connection to court to provide the monarch with a gift, a position many of the dedicators would have found themselves in (Heal 2014, 94). ${ }^{2}$ For Mary, her queen-era dedications followed three main themes: obedience, classical literature and philosophy, and the return of the true religion, while almost always reinforcing Mary's virtue, and the subject matter of the books themselves often followed the same four ideas (Schutte 2015,49 ). The dedications to Elizabeth in the first five years that she was queen mostly addressed religion (of varying sorts), virtue, and the increase of knowledge, whether classical or modern anatomy or architecture.

For both queens, dedications often followed a similar rhetorical pattern. A dedication would begin with praise, either of the queen's virtue, lineage, or education, would then briefly explain the text which the dedication accompanied, would explain why the text reminded the dedicator of that specific queen, and would end in some type of prayer or wish for prosperity and a long reign. For example, John Veron noted Elizabeth's "princelye goodness," as he

\footnotetext{
${ }^{1}$ Manuscripts dedicated to Queen Elizabeth include British Library (BL), Royal MS $5 \mathrm{E}$ XVII; BL, Royal MS 2 D II; BL, Royal MS 12 A XXX, Wellcome Library MS 136. For a detailed discussion of manuscripts dedicated to Queen Mary, see Schutte $(2015,81-$ 101). According to Natalie Zemon Davis, the act of gift-giving required action by both giver and receiver; a New Year's gift not only honored the monarch but implied desire for patronage during the upcoming year (2000, 14 and 24). Felicity Heal has recently published on gift-giving in England. See especially her chapter "The Politics of Gift-Exchange under the Tudors" (2014, 87-120).

2 Heal suggests that Elizabeth had "enthusiasm for elegantly bound volumes, alongside the more obvious clothes and jewels" (2014, 97-98).
} 
was a stranger to her and presented his book as a blind offering to her (Veron, 1561, C.iii.r). Once Veron offered Elizabeth such praise, he was then able to explain his text and thoughts on predestination to ask Elizabeth to accept his text and pass it on so that it could become known to her subjects. Veron, like so many other dedicators to other sixteenth-century English royal ladies, specifically Lady Margaret Beaufort and the six consorts of Henry VIII, also implied how a royal connection made a text more valuable, sellable, and authoritative (Schutte 2015, 7). ${ }^{3}$

\section{Counsel}

Unlike when Mary and Elizabeth were princesses, dedications to the queens were more forthcoming in offering counsel, as it was wellknown that monarchs needed good counsel so as to make good decisions (Schutte forthc.; Hoak 1995, 4). ${ }^{4}$ However, it was more critical to offer counsel to Mary and Elizabeth because it was not known how either woman would handle her power and perform her duties. Therefore, dedicators often noted that it was their bound duty to write these books and present them to the queen. Beyond duty, in order not to seem belligerent towards the queens, dedicators often couched their texts as being done for the good of the queen's subjects or for the good of the commonweal; their books were necessary to teach English people a lesson or remind them of their responsibilities. Yet, this professed duty was much more often a flattering way of saying that the dedicator was trying to offer some type of advice to the queen.

\footnotetext{
${ }^{3}$ Wood asserts that a "dedication to the Queen provided a cloak of legitimacy whether she knew the author or not" $(2008,6)$.

${ }^{4}$ Counsel is currently a popular historiographic trend that has mostly been done for kings, but studies on counsel to queens continue to be forthcoming. For an example of feminizing counsel within Tudor literature, see Ward (2013). Ward is particularly interested in how feminized counsel was portrayed on stage and suggests that the "rhetoric of counsel" changed with the reigns of Mary and Elizabeth, and on place that this is most evident is within tragedy plays, in which queens were often presented as counselors. Another recent study on late medieval counsel addresses mirrors for princes and their veiled political commentary (Ferster 1996). Joanne Paul and Helen Matheson-Pollock also have a forthcoming edited collection on queenship and counsel (2017).
} 
Mostly, dedicators counselled Mary in religion, specifically, to listen to her religious advisors who recommended the return of the Church of England back to Catholicism (Schutte 2015, 68-80). She was actually counselled by dedicators to follow the advice of her political council, implying that male dedicators thought that a queen regnant had to listen to male councilors because the nature of female rule was not yet fully established. Henry Parker, Lord Morley, longtime friend and supporter of Mary, wrote that she should follow "the wise counsel of the vnculpable, vertuous Cardinall, your cosyn," in matters of religion. ${ }^{5}$

Elizabeth was also counselled in religious matters, yet her dedicators often sought to steer her away from Catholicism, such as the dedication accompanying a Bible printed in Geneva by Elizabeth's "humble subiects of the English Churche at Geneua" (Bible, 1560, f. ii.r.). These (presumably) men counselled Elizabeth to be wary of her enemies (papists and prelates) and offered her the scriptures in English so that she did not have to listen to the false words of papists. Elizabeth, too, was counselled to choose good friends and counsellors as kings and queens attracted false friends. ${ }^{6}$ She was warned that the biblical King David encountered many enemies, so like David, she should rely on God to help her choose good counsellors (Boke of Psalmes 1559, *iiii,v.). ${ }^{7}$ Laurence Humphrey also advised Elizabeth take the advice of her counsellors, but at the same time warned her to get rid of treacherous nobles.

While all monarchs were expected to have counsellors and listen to their advice, these dedications show that dedicators to both Mary and Elizabeth thought that as queens they were more susceptible to taking bad advice and needed to surround themselves with qualified (male) counsellors. Thus, dedicators used dedications to surreptitiously offer their ideas to the queens, similarly to how panegyric verses also had the double meaning of providing council (Walsham 2003, 147).

\footnotetext{
${ }^{5}$ The dedications to all of Morley's manuscripts have been reprinted in Wright (1953, 183).
${ }^{6}$ Tara Wood suggests that dedicators "subtly" advanced "ideas of the commonwealth, and the duties of the citizen, usually while emphasizing that the she must rely on her advisors as responsible men" $(2008,175)$. The typo is in Wood's dissertation.

${ }^{7}$ This dedication is missing at least the first page on EEBO, so it is not possible to determine the exact dedicator.
} 


\section{Religion}

Again as in the pre-accession dedications, religion was the most common theme in the dedications to Queens Mary and Elizabeth. Dedicators addressing both Mary and Elizabeth sought to influence and support religious change. Dedications to Mary exhorted her to return England to the true religion of Catholicism, while those to Elizabeth were much more varied in scope (Schutte 2015, 68-80). Elizabeth received dedications advocating predestination, religious reform, and even Catholicism. This variation in dedications to Elizabeth shows the desire for religious reform by both Catholics and Protestants at the outset of Elizabeth's reign. Elizabeth's religious settlement, while re-instating stateled religion, was much more moderate in nature than her brother's settlement had been, thereby allowing all religious sects to attempt to counsel Elizabeth how to set up the newly re-established Church of England. When Mary became queen, there was no such confusion, as it was wellknown that she desired a reconciliation with Catholicism.

One important similarity in the religious dedications directed to both queens was the way in which many dedicators suggested that each woman was placed on the throne through God's will. Mary became queen because God wanted to return England to Catholicism, while Elizabeth became queen by divine will to purify the Church of England. This similarity is significant, because scholars have previously emphasized the providential nature of literary sources associated with Elizabeth, but have not made the same connections for Mary. ${ }^{8}$

For Elizabeth, several of her early dedications mentioned that she was placed on the throne by divine providence because of her Protestantism. In 1559, the dedication by anonymous subjects residing in Geneva accompanying The Boke of Psalmes noted that "God had not lesse miraculously p[re]ferred you to that excellent dignitie [...] aboue all mens expectations," meaning that God incredibly made her queen after having to endure the reign of Mary (Boke of Psalmes, 1559, *.iii.r). In another text printed shortly after Elizabeth's accession, Joannes Ferrarius claimed that "it hath pleased the greate Lord [...] to enstall your highnesse by his diuine

\footnotetext{
${ }^{8}$ Susan Doran has written about how John Foxe's dedication to Elizabeth heralded in peace, prosperity, and reform $(2003,172)$.
} 
prouidence, in the Roialle throne of maiestie" (1559, C.ii.r). Similarly, John Foxe argued that God gave England Elizabeth because so much persecution was done before she was queen (1563).

Yet Mary's propagandists also saw her as placed on the throne through divine intervention after the religiously oppressive reign of her brother, Edward. Richard Smith noted that Mary was "preserved" for many years under her enemies but with God's "singuler help" Mary was able to take the throne (Smith 1554, C.ii.vC.iii.r). Mary had neither riches nor political power, but was able to overthrow her enemies with the help of God. Likewise, Robert Recorde argued that "Godde in despite of cancred malyce and of frowninge fortune, dyd exaulte your maiestie to that throne royall, which iustice dyd belonge vnto your highness" (Recorde 1556, a.ii.r). The rhetorical strategy of divine favor, then, was first used with Mary but was taken over by Elizabeth's dedicators, and later used within the myth that England was favored by God for its Protestantism.

Images of powerful biblical women were also first used by Marian propagandists to describe Mary, but were later taken over by Elizabethan propagandists. ${ }^{9}$ At Mary's coronation, she was compared with Judith and Judith's defeat over Holofernes. ${ }^{10}$ Holofernes was probably meant to be representative of Edward and his religious settlement that Mary defeated within only a few months of becoming queen. These same biblical females were also compared to Mary in book dedications. In his dedication, John Angell wrote that England had recently been full of people who interpreted Scripture for themselves, "Tyll suche tyme that it pleased God of his infinite mercy, to sende us a newe Judith, by whose godlines the trewe light and knowledge of Goddes worde is nowe by her brought agayne" (Angell 1555, A.ii.v-A.iii.r). These female biblical figures were then "commandeered" by authors to represent Elizabeth because the connection between royal lady and biblical lady was so dominant (Kewes 2010, 48). Laurence Humphrey noted that though

\footnotetext{
${ }^{9}$ It is now recognized that Elizabeth and her propagandists borrowed much for Mary, and in some instances had to overtake the images used by Mary because they were so powerful (Kewes 2010, 47, 58-59; Wood 2008, 126).

${ }^{10}$ Duncan suggests that Holofernes was meant to represent Northumberland, whom Mary defeated in order to take the throne from Lady Jane Grey (2012, 161; King 1989, 218-19).
} 
Elizabeth was a woman, God preferred her and made her queen, just as He preserved several biblical women, such as Judith and Deborah (Humphrey 1563, B.i.r). ${ }^{11}$

\section{The Queen as King}

Dedications to Mary and Elizabeth share one other surprising image: the queen as king. Carole Levin has convincingly argued that Elizabeth considered herself to be both queen and king and that many authors represented her as such (Levin 2013, 131 and 148). Yet Marian scholars have recently shown that Mary, too, exhibited kingly characteristics, such as at her coronation and when she touched for scrofula (Richards 2008, 122, 137, 242; Duncan 2012, 27). Dedicators also contributed to Mary's image as king, more so than has previously been recognized (Schutte 2015, 56-57). In his dedication to his text on Wyatt's Rebellion, John Proctor twice noted that traitors "who through hatred to their prince or countrey shall either of their own malicious disposition be stirred" (1554-1555, a.iii.r) and "or of malice to their prince wyll entre into that horrible crime of preuie conspiracie or open rebellion" (1554-1555, a.iii.r). Proctor used the term "prince" in the general context of a leader, reinforcing Mary's legitimate right to be the sovereign, even when participants in Wyatt's Rebellion thought otherwise. This is in drastic contrast with many of the other dedications received by Mary, and many of those received by Elizabeth, in which the dedicators referred to Mary as both queen and princess, perhaps suggesting less power than a prince might have had.

One other dedicator to Mary, James Cancellar, in his dedicatory epistle to another book on obedience, made a biblical reference to the Book of Deuteronomy and how in it the children of Israel were called to be obedient to God. Cancellar's full title mentioned that all subjects needed to be obedient to both the king and queen, but the dedication was only directed towards Mary. This is important because in the dedication Cancellar noted that subjects ought to be obedient to their "king and gouernor," especially those who served him and made their living by him (Cancellar 1553, A.ii.v). Cancellar

\footnotetext{
${ }^{11}$ Wood suggests that Humphrey used his dedication as a commentary on female rule, suggesting that Elizabeth should reform the church as her father and brother had done, but in a traditional female way $(2008,94)$.
} 
used the term "king" as it was the term used in Deuteronomy, however, Cancellar did not qualify the term in any way. Therefore, in making a dedication to Mary that argued for the duty of obedience to the king, or supreme leader, Cancellar implied that Mary was both queen and king, which is why she deserved complete obedience (Schutte 2015, 55). Dedications such as these, should be used in conjunction with emerging Marian studies of her image, both created by her and for her, and her strategies of rulership to get a more even-handed and accurate picture of Mary as queen and what she demonstrated for Elizabeth (Richards 2010, 31-46).

Dedications in the first five years of Elizabeth's reign did not refer to Elizabeth as king, but as princely. Like Proctor, dedicators did not consider Elizabeth to be King of England, but did understand her to be the prince and legitimate ruler of England. Peter Whitehorne, in his dedication to his translation of Niccolo Machiavelli's The arte of W arre, noted that he dedicated his book on war to Elizabeth because wartime preparations were "determined by the abritremente of Gouernours and Princes" (Machiavelli 1562, a.iii.v). Thomas Bloundeville dedicated his translation of Plutarch's Three morall treatises to Elizabeth because in these treatises Plutarch shows where "a Prince ought most texcell" (Plutarch 1561, A.ii.r). And, John Veron wrote to Elizabeth that she had "Princelye goodness" and a "princelye harte" (Veron 1561, C.iii.r-C.viii.v) while John Foxe wrote of Elizabeth's "princely benignitie" (1563, B.ii.v). As for Mary, these dedicators did not qualify their use of the term "prince," thereby acknowledging that Elizabeth was their ruler and giving way to the later images of Elizabeth as both king and queen. Only one dedicator truly faulted Elizabeth for her sex, and that was Laurance Humphrey, who several times over the course of his eighteen-page long dedication mentioned that Elizabeth lacked the power of a "manlye kynge," yet was a successful queen, although what she accomplished was through God's work and not her own (H umphrey 1563, A.ii.v).

However, the anonymous members of the English church in Geneva made a much stronger case for Elizabeth as both king and queen of England. In their dedication, they compared Elizabeth to the biblical King David, as both she and David withstood "perils and persecutions" before attaining the throne, referencing Elizabeth's confinement in the Tower during her sister's reign (Boke of Psalmes 
1559, *ii.v). Likewise, the dedication frequently repeats that God put both her and David on the throne, so she should find comfort in God and that it is her duty to support His true (reformed) religion. This comparison of Elizabeth and David was not done because the members of the English church in Geneva regarded Elizabeth as King of England, but because David was a providential monarch, like Elizabeth, so he was a biblical figure from whom Elizabeth could learn how to govern (Doran 2010, 96; Walsham 2003, 147). However, it is through comparisons such as this that Elizabeth was able to fashion her image as both king and queen. But it is important to note that before Elizabeth, Mary had similar implications made of her status, thereby revealing that having a female monarch regarded as both king and queen was not novel with Elizabeth, only made clearer as Elizabeth's reign was significantly longer and Elizabeth ultimately chose not to marry.

\section{Statecraft}

Tellingly, there are some significant differences between the book dedications to Mary and Elizabeth. The most notable difference is how dedicators treated statecraft. Tara Wood noted that of the 183 printed dedications that Elizabeth received, almost all explored religion in some way, while others accompanied texts on "shorthand to science and statecraft" $(2008,6)$. Peter Whitehorne suggested in his dedication to The arte of warre that it was important to know of arms and defense because no real $m$ was free from using them. It was his duty to offer a text that would increase knowledge on the subject of war. He specifically dedicated his translation to Elizabeth because not only would her name give special authority to the text, but also "for the better defence of your highnesse," her subjects, and the realm (Machiavelli 1562, a.iii.r). As a woman Elizabeth would not have been expected to have been educated in military strategy, yet dedicators such as Whitehorne were pragmatic enough to realize that Elizabeth would need some sort of guidance should the need arise. $^{12}$

\footnotetext{
${ }^{12}$ Wood suggests that Whitehorne's dedication shows male anxiety over having a queen regnant, as Whitehorne suggests that educating male subjects in war will increase virility $(2008,189-90)$.
} 
Mary, on the other hand, did not receive any books or dedications on statecraft. No author gave Mary advice how to act politically as queen, instead mentioning in their dedications that Mary was surrounded by good council. For example, Robert Recorde wrote that "God not only hath endewed [Mary] with excellent knowledge, but also hath ayded with such prudent Councellars" (1556, a.ii.v). Elizabeth had qualified councilors as well, but dedications such as Whitehorne's suggest that English people accepted Elizabeth's role as head of the political realm more so than was accepted for Mary. I argue that dedicators to Mary did not address statecraft because it was assumed that politics was outside of Mary's purview even though she was queen; Mary's councilors would make political decisions for her. Even the books that Mary received in the aftermath of political rebellions did not address that Mary needed to know how to take charge with arms, but instead offered her advice of how to better command the obedience of her people (Cancellar 1553; Proctor 1554-1555). After Mary's marriage to Philip II of Spain, dedicators always mentioned both Mary's Engl ish and Spanish titles, but almost never mentioned Philip by name or even at all. The couple only received five joint dedications (Schutte $2015,105)$. This suggests that dedicators did acknowledge that Mary had superior authority in the realm, even over the king, but that dedicators were still not quite ready for a woman to rule politically (Schutte 2015, 103-15). By the accession of Elizabeth it was recognized that a female ruler did at least need some political knowledge, but it was still expected that male councilors would be making most of the political decisions.

\section{Conclusion}

This essay has briefly compared printed book dedications to Mary and Elizabeth Tudor before each woman became queen and during their first five (or only five) years as queens. As queen, Mary received twenty-five printed book dedications, while Elizabeth received only fourteen during her first five years as queen, and each woman also received several manuscript dedications. Those dedications had many similarities. They often followed the same rhetorical patterns, acknowledged that connection to a royal patron would lead to greater sales and influence of their books, and offered some type of covert advice to the queens under the guise of flattery. 
Even though religious policy was not typically an area under a woman's purview, the amount of dedications to both women dealing with religion suggests that dedicators were more comfortable with their queens having an impact on religion more so than statecraft.

Yet, dedications to the Tudor sisters as queens show that these two women were perceived more commonly than has previously been recognized. Both received veiled counsel, both were expected to have more power over religion than statecraft, and both were thought to need guidance on how to maintain the obedience of their people. This essay suggests that for all of their differences as princesses, the book dedications to Mary and Elizabeth as queens are incredibly similar. By exploring these book dedications, it becomes evident that dedications were central to contemporary perceptions of what authors and translators thought Mary and Elizabeth would be interested in reading and passing along to their subjects al ong with what dedications thought the sister queens should be reading so as to be persuaded in different directions.

\section{References}

Manuscripts

London, British Library (BL), Royal MS5E XVII

London, BL, Royal MS2 D II

London, BL, Royal MS 12 A XXX

London, Wellcome Library, MS 136

\section{Printed primary sources}

Angell, John. 1555. The agrement of the holye fathers, and D octors of the churche, vpon the cheifest articles of Christian religioun as appeareth on the nexte syde folowinge, very necessary for all curates. London: William Harford. STC 634.

Bible and Holy Scriptures conteyned in the Olde and Newe Testament, The. Translated by William Whittingham. Geneva: Rouland Hall, 1560. STC 2093.

Boke of Psalmes where in are conteined praiers, meditations, praises \& thankesgiuing to God for his benefites toward his church, The. Geneva: Rouland Hall, 1559. STC 2384.

Cancellar, James. 1553. The Pathe of 0 bedience, righte necessarye for all the king and Quenes maiesties louing Subiectes, to reade, learne, and use their due 
obediences, to the hyghe powers accordynge to thys godly treatise compiled by James Cancellar, one of the Quenes M aiesties moste honourable Chapell. London: John Wayland. STC 4564.

Ferrarius, Johannes, Touchynge the good orderynge of a common weale wherein aswell magistrates, as priuate persones, bee put in remembraunce of their dueties, not as the philosophers in their vaine tradicions haue deuised, but according to the godlie institutions and sounde doctrine of christianitie. Englished by william Bauande. London: John Kingston, 1559. STC 10831.

Foxe, John. 1563. Actes and monuments of these latter and perillous dayes touching matters of the Church, wherein ar comprehended and decribed the great persecutions [and] horrible troubles, that haue been wrought and practiced by the Romishe prelates, speciallye in this realme of England and Scotlande, from the yeare of our Lorde a thousand, vnto the tyme now present. London: John Day. STC 11222.

Hannapes, Nicholas de. 1561. The ensamples of vertue and vice, gathered oute of holye scripture. Translated by Thomas Paynell. London: J. Tisdale. STC 12742.

Humphrey, Laurence. 1563. The nobles or of nobilitye. London: Thomas Marsh. STC 13964.

Machiavelli, Niccolo. 1562. The arte of warre, written first in Italia[n] by $\mathrm{Nicholas} \mathrm{M}$ achiauell, and set forthe in Englishe by Peter Whitehorne Translated by Peter Whitehorne. London: John Kingston. STC 17164.

Plutarch. 1561. Three morall treatises no lesse pleasaunt than necessary for all men to reade, wher of the one is called the learned prince, the other the fruites of foes, the thyrde the port of rest. London: William Seres. STC 20063.5.

Proctor, John. 1554-1555. The historie of wyates rebellion, with the order and maner of resisting the same, wherunto in the en de is added an earnest conference with the degenerate and sedicious rebelles for the serche of the cause of their daily disorder. London: John Caly. STC 20407.

Recorde, Robert. 1556. The castle of knowledge. London: Reginald Wolfe. STC 20796.

Smith, Richard. 1554. A bouclier of the catholike fayth of Christes church, conteynyng diuers matters now of late called into controuersy, by the newe gospellers. London: Richard Tottell. STC 22816.

Veron, John. 1561. A fruteful treatise of predestination, and of the deuyne prouidence of god as far forth as the holy scriptures and word of god shal lead vs. London: John Tisdale. STC 24680.

\section{Secondary sources}

Baranda Leturio, Nieves. 2011. “Women's Reading Habits: Book Dedications to Female Patrons in Early Modern Spain." In Women's Literacy in Early 
Schutte

Modern Spain and the New World, edited by Anne J. Cruz and Rosilie Hernández, 19-39. Surrey: Ashgate.

Brogan, Stephen. 2015. The Royal Touch in Early Modern England: Politics,

M edicine, and Sin. Suffolk: Boydell \& Brewer.

Buchte, John. 2004. "Book Dedications and the Death of a Patron: The Memorial Engraving in Chapman's Homer." Book H istory 7: 1-29.

- - - 2008. "'To the Most High and Excellent Prince': Dedicating Books to Henry, Prince of Wales." In Prince H enry R evived: I mage and Exemplarity in Early Modern England, edited by Timothy V. Wilks, 104-33. London: Holberton.

Burke, Mary E., Jane Donawerth, Linda L. Dove, and Karen Nelson, eds. 2000. W omen, W riting, and the Reproduction of Culture in Tudor and Stuart Britain. Syracuse, NY: Syracuse University Press.

Crawford, Julia. 2014. M ediatrix: Women, Politics, and Literary Production in Early M odern England. Oxford: Oxford University Press.

Davis, Natalie Zemon. 2000. The Gift in Sixteenth-Century France. Madison: The University of Wisconsin Press.

Doran, Susan. 2003. "Virginity, Divinity and Power: The Portraits of Elizabeth I." In The M yth of Elizabeth, edited by Susan Doran and Thomas S. Freeman, 171-99. New York: Palgrave Macmillan.

_- - 2010. "Elizabeth I: An Old Testament King." In Tudor Q ueenship: The Reigns of $M$ ary and Elizabeth, edited by Alice Hunt and Anne Whitelock, 95-110. New York: Palgrave Macmillan.

Dowling, Maria. 1986. H umanism in the A ge of Henry V III. Kent: Croom Helm, Ltd.

Duncan, Sarah. 2011. "The Two Virgin Queens: Embodying Queenship in the Reigns of Mary I and Elizabeth I." In Elizabeth I and the "Sovereign Arts": Essays in History, Literature, and Culture, edited by Donald Stump, Linda Shenk, and Carole Levin, 29-52. Tempe: Arizona Center for Medieval and Renaissance Studies.

_-_. 2012. M ary I: Gender, Power, and Ceremony in the Reign of England's First Q ueen. N ew York: Palgrave Macmillan.

Erler, Mary C. 2002. Women, Reading, and Piety in Late M edieval England. Cambridge: Cambridge University Press.

Ferster, Judith. 1996. Fictions of A dvice: The Literature and Politics of Counsel in Late M edieval England. Philadelphia: University of Pennsylvania Press.

Frye, Susan. 2010. Pens and Needles: Women's Textualities in Early M odern England. Philadelphia: University of Pennsylvania Press. 
Goldsmith, Elizabeth C. and Dena Goodman. 1995. Going Public: Women and Publishing in Early M odern France. Ithaca, NY: Cornell University Press.

Guardiola-Griffiths, Cristina. 2011. Legitimizing the Queen: Propaganda and Ideology in the Reign of I sabel I of Castile. Lewisburg: Bucknell University Press.

Heal, Felicity. 2014. The Power of Gifts: Gift-exchange in Early M odern England. Oxford: Oxford University Press.

Hannay, Margaret P. 1985. Silent But for the Word: Tudor Women as Patrons, Translators, and Writers of Religious Works. Kent, $\mathrm{OH}$ : Kent State University Press.

Hoak, Dale. 1995. Tudor Political Culture. Cambridge: Cambridge University Press.

Hull, Susanne W. 1982. Chaste, Silent \& O bedient: English Books for Women, 1475-1640. San Marino, CA : Huntington Library Press.

Hunt, Alice and Anna Whitelock, eds. 2010. Tudor Queenship: The Reigns of $M$ ary and Elizabeth. New York: Palgrave Macmillan.

Kewes, Paulina. 2010. "Godly Queens: The Royal Iconographies of Mary and Elizabeth." In Tudor Q ueenship: The Reigns of M ary and Elizabeth, edited by Alice Hunt and A nne Whitel ock, 47-62. N ew York: Palgrave Macmillan.

King, John. 1989. Tudor Royal Iconography: Literature and Art in an Age of Religious Crisis. Princeton: Princeton University Press.

Levin, Carole. 2013. The H eart and Stomach of a King: Elizabeth I and the Politics of Sex and Power. $2^{\text {nd }}$ ed. Philadelphia: University of Pennsylvania Press.

M clntosh, J.L. 2009. From H eads of $\mathrm{H}$ ousehold to $\mathrm{H}$ eads of State: The Preaccession H ouseholds of M ary and Elizabeth Tudor, 1516 to 1558. N ew York: Columbia University Press.

Moore, Helen. 2011. "Gathering Fruit: The 'Profitable' Translations of Thomas Paynell." In Tudor Translation, edited by Fred Shurink, 39-57. New York: Palgrave Macmillan.

Paul, Joanne and Helen Matheson-Pollock. 2017. Q ueenship and Counsel in the Early M odern World. New York: Palgrave Macmillan.

Pollnitz, Aysha. 2015. Princely Education in Early M odern Britain. Cambridge: Cambridge University Press.

Richards, Judith M. 2008. M ary Tudor. London: Routledge.

- - 2010. "Examples and Admonitions: What Mary Demonstrated for Elizabeth." In Tudor Q ueenship: The Reigns of M ary and Elizabeth, edited by Alice Hunt and A nna Whitelock, 31-46. New York: Pal grave Macmillan.

_-_. 2012. Elizabeth I. London: Routledge. 
Schutte

Schutte, Valerie. 2015. M ary I and the Art of Book Dedications: Royal Women, Power, and Persuasion. New York: Palgrave Macmillan.

-_- 2016. "Under the Influence: The Impact of Queenly Book Dedications on Princess Mary." In The Birth of a Queen: Essays on the Q uincentenary of M ary I, edited by Sarah Duncan and Valerie Schutte, 3148. New York: Palgrave Macmillan.

-_- (forthcoming). "Perceptions of Princesses: Pre-accession Book Dedications to Mary and Elizabeth Tudor." In U nexpected H eirs in Early Modern Europe: Potential Kings and Queens, edited by Valerie Schutte. New York: Palgrave Macmillan.

Smith, Helen. 2012. "Grossly M aterial Things": Women and Book Production in Early M odern England. Oxford: Oxford University Press.

Walsham, Alexandra. 2003. "'A very Deborah?' The Myth of Elizabeth I as a Providential Monarch." In The M yth of Elizabeth, edited by Susan Doran and Thomas S. Freeman, 143-68. N ew York: Palgrave Macmillan.

Ward, Allyna E. 2013. Women and Tudor Tragedy: Feminizing Counsel and Representing Gender. Madison: Fairleigh Dickenson University Press.

Wood, Tara. 2008. "'To the most godlye, virtuos, and myghtye Princess Elizabeth': Identity and Gender in the Dedications to Elizabeth I." PhD diss., A rizona State University.

Wright, Herbert G. 1943. Forty-six Lives. London: Early English Text Society.

How to cite this article:

Schutte, Valerie. "Perceptions of sister queens: A comparison of printed book dedications to Mary and Elizabeth Tudor." SED ERI 27 (2017): 149-66.

A uthor's contact: veschutte@gmail.com

Postal address: Independent Scholar - Pittsburgh, PA, USA

Submission: 19/ 10/ 2016

A cceptance: 15/ 11/ 2016 


\title{
"For know, alas, I'm dumb, alas I love": Rhetoric of disability, female agency and tragedy in "The Dumb Virgin"
}

\author{
Juan de Dios Torral bo Caballero \\ U niversidad de Córdoba, Spain
}

\begin{abstract}
This essay will focus on the two sisters of "The Dumb Virgin; or, The Force of Imagination," addressing the crossover between disability studies, feminism and aesthetic theory. It will examine how art has the capacity to manipulate nature and how nature may be improved by the intervention of human industry. With this aesthetic duality, it will suggest that the writer reframes the concept of the 'normal' body, establishing a rhetoric of deformity and disability through the characters of Belvideera and Maria, both of whom overcome their natural disabilities by means of personal effort. Lastly, it will investigate the 'misfortunes' of several characters, paying particular attention to the educated nature of the two protagonists and how this poses a threat to the established order of society. The condusion to be drawn from this is that their challenge to the social construct is directly responsible for the tragic climax of the narrative.
\end{abstract}

KEYWORDS: Aphra Behn; "The Dumb Virgin"; female agency; rhetoric of disability and deformity; Restoration literature.

\section{"For know, alas, I'm dumb, alas I love": retórica de la discapacidad, agencia femenina y tragedia en "The D umb Virgin"}

RESUMEN : Este trabajo se centra en las dos hermanas de "The Dumb Virgin; or, The Force of Imagination" considerando la intersección entre los estudios de la discapacidad, el feminismo y la teoría estética. Se estudia cómo el arte puede manipular a la naturaleza y cómo la naturaleza puede ser mejorada por la intervención del esfuerzo humano. Con esta dualidad estética se plantea cómo la autora re-conceptualiza la noción de 'cuerpo normalizado' mediante la retó-

\section{"For know, alas, I'm dumb, alas I love": Retórica da deficiência, agência feminina e tragédia em "The D umb Virgin" ${ }^{*}$}

RESUMO: Este estudo centra-se nas duas irmãs de "The Dumb Virgin; or, The Force of Imagination", considerando a intersecção entre os estudos da deficiência, feminismo e teoria estética. Examinase de que forma a arte tem a capacidade para manipular a natureza e de que forma a natureza pode ser melhorada através da intervenção do esforço humano. Com esta dualidade estética, sugere-se que a autora reconceptualiza a noção de "corpo normal", estabelecendo

* Translation into Portuguese by Miguel Ramalhete. 
rica de la deformidad y de la discapacidad en los personajes de Belvideera y Maria que superan sus disfunciones naturales mediante su esfuerzo. Finalmente, se investigan los 'infortunios' de varios personajes destacando a las dos protagonistas como formadas y educadas, como amenazas al orden social establecido. Se concluye que los trágicos finales se derivan del desafío realizado al constructo social.

PAlabras Clave: Aphra Behn; "The Dumb Virgin"; agencia femenina; retórica de la discapacidad y la deformidad; literatura de la restauración. uma retórica da deformidade e da deficiência através das personagens de Belvideera and Maria, superando ambas as suas deficiências naturais por via de um esforço pessoal. Finalmente, investiga-se os "infortúnios" de várias das personagens, prestando-se atenção em particular à educação das duas protagonistas e de que forma isto representa uma ameaça à ordem estabelecida da sociedade. A conclusão a retirar-se é de que o seu desafio ao construto social é diretamente responsável pelo final trágico da narrativa.

Palavras-Chave: Aphra Behn; "The Dumb Virgin"; agência feminina; retórica da deficiência e da deformidade, literatura da Restauração.

A family of ten children will be always called a fine family, where there are heads and arms and legs enough for the number; but the Morlands had little other to the word, for they were in general very plain, and Catherine for many years of her life, as plain as any.

N orthanger A bbey (Austen 2006, 5)

\section{Introduction}

Before Sarah Scott's construction of a feminotopia ${ }^{1}$ in M illenium Hall (1762) and William Hay's theories regarding disability in D eformity. An Essay (1754), whereby he conceptualizes it as a privileged condition, the author of this short fiction ${ }^{2}$ (published under Aphra Behn's name) developed a comparable symbolic content that is worthy of further investigation.

\footnotetext{
${ }^{1}$ The term was coined by Marie-Luise Pratt $(1992,166-68)$ and used in reference to the work of Sarah Scott by Felicity Nussbaum (1997, 161-73).

${ }^{2}$ Leah Orr $(2013,30)$ questions the authorship of "The Dumb Virgin" and other stories traditionally attributed to Behn by specialized critics like O'Donnell (2004b, xxii), Trofimova $(2011,1)$, etc. These doubts of attribution had al ready been raised by Janet Todd $(1996,317)$ in her biography of Behn.
} 
This text considers the notion of femininity as a social construct (Armstrong 1987, 30) ${ }^{3}$ as well as a fictional structure, in terms of which the behavior of the protagonists of "The Dumb Virgin; or the Force of the Imagination" (1698) ${ }^{4}$ must be properly understood. Within this conceptual framew ork, the notions of female agency, the rhetoric of deformity and disability studies (Garland-Thomson 2002, 1) become wholly relevant.

This article will investigate how the literary writer demonstrates the ability of art to manipulate nature in compensation for the abnormal bodies of her female heroes (Belvideera and Maria). It discusses how the protagonists are capable of overcoming their natural disabilities by means of their industry and study. It also investigates how the writer subverts the female image and the established idea of the normalized body, making a strong case for greater female agency. This working hypothesis will be developed further addressing the aesthetic argument in the context of the rhetoric of disability and in the connection between deformity studies, feminism and aesthetic theory.

At this point it is worth acknowledging the generic construction of the text, as a romance and as a fiction, since this sheds light on certain elements of the plot. According to Michael McKeon, literature "crystallizes genreness [...] self-consciously incorporating it, as part of its form, the problem of its own categorial status" (2017, 67). Although McKeon refers here specifically to the novel, it is arguably equally applicable to this short story. In this respect, there is considerable relevance in the differentiation ${ }^{5}$ established by

\footnotetext{
${ }^{3}$ "The Dumb Virgin" has been subject to little critical analysis, with only few articles devoted exclusively to it (Craft-Fairchild 1993, Robitaille 1997, Nussbaum 2000 and 2003, Bowles 2012). Yao-Hsi (2014) has carried out a general investigation of the defective characters in several works published under the name of Behn. TorralboCaballero (2015) revisited questions of gender and examined other aspects such as realism and eroticism in the character of Maria.
}

4 "The Dumb Virgin" was printed-but not published-in 1698 along with "The Unfortunate Bride" and "The Unfortunate Happy Lady." These works were published in 1700 in Histories, N ovels, and Translations W ritten by the M ost Ingenious M rs Behn. It is possible that "all three short stories" were produced "as part of a "Second Volume'" (Todd 1995, 326) of All the Histories and N ovels published in 1698 (O'Donnell 2004b, xixxii).

${ }^{5}$ Certain writers of the following century attempted to define and categorize these terms. For instance, in 1742 Henry Fielding defined "a comic Romance" as "a comic Epic-Poem in Prose" in his preface to Joseph A ndrews (1980, 4). Later, in The Progress of 
William Congreve in the same period. He clarifies that "Romances are generally composed of the constant loves and invincible courages of heroes, heroines, kings and queens, mortals of the first rank, and so forth, where lofty language, miraculous contingencies and impossible performances elevate and surprise the reader into a giddy delight," while "Novels are of a more familiar nature: come near us, and represent to us intrigues in practice; delight us with accidents and odd events, but not such as are wholly unusual or unprecedented [...]" (Congreve 2003, 5).

The story contains certain elements that are clearly remnants of the romance tradition - "romance strategies" (Fuchs 2004, 31) _ such as the early death of the mother, orphan children, fantasy, hyperbole and sword-play. These elements illuminate the protagonists' successful attempts to overcome their disabilities. At the same time, however, the story also incorporates aspects that indicate a developing sense of realism, such as specific details relating to location and time. These include references to the Adriatic Sea, Venice, the Ponte di Rialto, and St. Mark's Basilica, as well as the ten minutes during which Dangerfield is involved in a swordfight. There are also historically relevant references, such as the skirmish between the Venetian and Turkish fleets, and the character of the Turkish merchant. This fusion of elements justifies the view of "The Dumb Virgin" as being a hybrid work in terms of its genre, embodying as it does the transition between a preceding literary period (romance) and the early modern era (fiction, the novel).

\section{M aster tropes of deformity and disability}

The first episode narrated in the text focuses on the mother of the protagonists. It presents a movement from the internal to the external environment, from domesticity towards the public sphere. ${ }^{6}$

Romance Clara Reeve $(1785,1,8)$ presents a comparison between the romance genre and the novel through a dialogue in which one of her characters, Euphrasia, defends the romance, while another-Hortensius - criticizes it. Reeve proposes "to follow its progress [romance's] through the different periods to its declension, to shew how the modern Novel sprung up out of its ruin, to examine and compare the merits of both, and to remark upon the effects of them" $(1785,1,8)$.

${ }^{6}$ The act of writing this story on the subject of the interiority of women (i.e. their secrecy) in itself stands as an act of participation in the public sphere. With regard to Belvideera and Maria's public presence, of great relevance is the concept introduced 
The wife of Senator Rinaldo is presented as "beautiful and virtous" as well as "disturbed by the following occasion" (341). The verb "disturb" is fundamental: its inclusion in the opening paragraph expresses a disruption of the normal from the outset of the work. At this point, Rinaldo and his wife are happy, and they have a young son; however, the mother (the writer does not reveal her name) ${ }^{7}$ develops a desire to travel to the Adriatic Sea to a place of "benign climate [...] situated exactly between Italy and Greece" that "appears an entire epitome of all the pleasures in them both." The "glories of the Island" (341) will be the trigger that sets in motion all the subsequent tragic events.

The wife of Rinaldo fails to secure the happiness she desires; during the voyage her ship is attacked by a band of Turkish pirates and her son falls overboard and disappears, presumed to have drowned. In this way, the mother's decision to follow her own desires leads directly to the loss of her son. In other words, her audacious determination to make a sea voyage simply for pleasureleaving her home and her country, abandoning her domestic life in Venice (and by extension her home, her family context and her husband)-is the cause for the first great tragedy of the narrative, affecting not only the woman who followed her desires by taking this trip but also her husband, who is equally tormented by the disappearance of their son. Furthermore, the pursuit of female desire on the part of the mother leads to the physical deformities in the children she bears following the tragedy at sea. The courage and desire to travel to terra incognita has its "just reward."

The mother tries to alleviate her suffering by conceiving again; however, this daughter (Belvideera) is born with physical abnormalities. Later, wishing again to ease her profound state of

by Jürgen Habermas and modulated by McKeon, specifically that: "The most visible case in point regarding the inclusiveness of the emergent public sphere is that of women" $(2005,73)$. The root of the concept can be found in Habermas ([1962] 1989, 36-37). Tita Chico examines the concept of "public display of femininity," applying it to The Rover $(2000,127)$. See also the study carried out by Martine van Elk (2017, 27 80), particularly the first chapter.

${ }^{7}$ Rinaldo's wife, the mother of the protagonists, appears unnamed, anonymously. In contrast, their father is characterized by his name (Rinaldo) and through his political position as a senator in the city of Venice. By depicting the characters in this way, the short fiction author gives great emphasis to the social enhancement of men in contrast to the silence, the neutralization and the marginalization of their female counterparts. 
melancholy and sadness, she conceives again, in time giving birth to another daughter (Maria) who is born dumb. The mother dies in childbirth. A mechanism of cause and effect is established here, illustrating the intentions of the author. Belvideera is born with a "deformity" (344) described with her "limbs [...] distorted," her "back bent, and tho the face was the freest from deformity, yet had it no beauty to recompence the dis-symmetry of the other parts" (344). Maria, the other protagonist, is born with a "defect" (344), described as "the most beautiful Daughter [...] but naturally and unfortunately dumb" (344).

These two core thematic concepts reflect two master tropes: one of deformity, the other of disability, which stand in opposition to the rhetoric of sameness. The author's treatment of disability by means of not one, but two disabled heroines is innovative and unprecedented in English literature. The gendered embodiments of the protagonists are not merely formulations of non-normalized bodies (Mintz 2006, 2-5). The depiction of Maria (muteness) reflects an "extreme preference for female docility and silence" (Bowles 2012, 8). Similarly, the depiction of Belvideera (physical disfigurement) emphasizes deformity, anatomical malformation and the idea of the ill-shaped body, contrasting with the idealized expectation that women should be beautiful and graceful. Belvideera and Maria communicate perfectly. The two sisters are complementary since they "are presented as two parts that together make a whole" (Bowles 2012, 7), a fact that is expressed by the narrator as follows: "his [Dangerfield's] love was divided between the beauty of one Lady, and wit of another, either of which he loved passionately, yet nothing cou'd satisfy him, but the possibility of enjoying both" (349).

Felicity Nussbaum states that "in both cases the mother's reproductive power is compromised by immoderate desire, and her womb, the defective appendage, makes manifest her hidden faults to produce a more defective second category of flawed femininity in the second generation" $(2003,28)$. The portrayal of defective femininity permeates the misogynist narrative of the period, in which femininity itself is depicted as inherently defective, a perspective challenged by this writer.

It may be concluded that "The Dumb Virgin" reveals a belief in the idea of swift punishment as just reward for a person's behavior. 
The conception of individual misdeeds carrying a harsh punishment for the perpetrator and putting others close to them at risk follows the long-standing belief that condemned deformity as being an instance of divine wrath. This view was posited by thinkers such as Francis Bacon ${ }^{8}$ in 1612, Thomas Pope Blount ${ }^{9}$ in 1697 and Samuel Johnson in 1755. In this particular story the disabilities of the children are given as evidence of the mother's "sins." ${ }^{10}$

\section{The aesthetic duality of art and nature}

The two sisters are employed by the author to represent a key aesthetic duality. The work establishes a clear distinction between nature and art from the beginning when it defines the island in the Adriatic Sea as "a place wonderfully pleasant in the Summer, where art and nature seem to out-rival each other, or seem rather to combine in rendring the most pleasant of their products" (341). This allusion confirms the knowledge of this dichotomy on the part of the writer. The equality and complementarity that the narrator raises is further modified when it is indicated that Rinaldo intends to compensate for "the defaults of Nature by the industry of Art" (344). In the European society of Venice where the protagonists are born, there is no balance between nature and art, since Belvideera is deformed and Maria is disabled. For this reason, the father gives power to human intervention (ars) in an attempt to remedy the imperfections caused by nature.

${ }^{8}$ Francis Bacon, in "Of Deformity" (1612), establishes that "Ubi peccat in uno, periclitatur in altero" $(2012,426)$. Hay's publication, which follows the same format seen in "Of Deformity," challenged the message of Bacon's essay. Hay pointed out that "far from exhibiting the anti-social personality traits described by Bacon, the deformed person contributes materially to the physical, moral, and spiritual improvement of society [...]" (James-Cavan 2005, 28).

${ }^{9}$ Pope Blount ([1692] 1967, 99) affirms that "a received Opinion among the ancients that Outward Beauty, was an infallible Argument of inward Beauty; and so on the contrary, That a deformed Body was a true Index of a deformed Mind, or an ill Nature."

${ }^{10}$ Samuel Johnson, in his Life of Pope (1781), justified the physical deformities of the poet Alexander Pope as being due to his behavior: "he was of a constitution originally feeble and weak, and as bodies of a tender frame are easily distorted his deformity was probably in part the effect of his application" (1984, 725). In his dictionary, Johnson (1755) defines "deformity" as "Ridiculousness" and "the quality of something worthy to be laughed at." 
Rinaldo declares his intentions, echoing those of the female writer, whose exercitatio ("industry of Art") appeared within a literary spectrum monopolized by male voices and in a society that fostered "constructions of femininity as deformity" (N ussbaum 2003, 24). The tools that their father applies are "the greatest provision for their breeding and education" (344), whose effect was immediately visible, resulting in prodigious progress and a remarkable degree of compensation for the disabilities suffered by the two daughters. Belvideera learns to speak "all the European Languages" (344), achieving the same profundity of knowledge and skill in her mental capacities and linguistic fluidity; as Maria grows she becomes increasingly beautiful, while "the language of her Eyes sufficiently paid the loss of her Tongue" (345).

The author reframes the classic arguments about natura and ars, reflecting her understanding of this crucial Renaissance-era diatribe tackled by Sir Philip Sidney ${ }^{11}$ and Shakespeare ${ }^{12}$ among others. Half a century later, the critic Samuel Johnson alluded to the manipulation of nature by art when he used the simile of the diamond in these terms: "as a diamond [...] may be polished by art, and placed in such situation, as to display that lustre which before was buried among common stones" $(2008,176){ }^{13}$

There is a connection between this aesthetic duality and the rhetoric of disability. The writer demonstrates how nature can be manipulated through the industry of art. Other authors argued that nature is capable of being "methodized." John Dryden stated that "the knowledge of Nature was the original rule, and all poets ought to study her [...] that those things which delight all ages must have been an imitation of Nature" ([1677] 2006, 2130). Similarly, Alexander Pope declared "Those Rules of old discovered, not devised| Are Nature still, but Nature Methodiz'd" showing that "N ature and Homer were [...] the same" ([1711] 2008, 3-5). This idea was also expressed by Congreve in Incognita, where he establishes

\footnotetext{
${ }^{11}$ Sidney affirms that "there is no art delivered to mankind that hath not the works of Nature for his principal object" $(2002,84)$.

${ }^{12}$ A similar opinion is voiced by Polixenes in Shakespeare's The Winter's Tale when he claims that "Nature is made better by no mean| But Nature makes that mean: so, over that art, | Which you say adds to Nature, is an art| That Nature makes" (4.3.88-91). In $\mathrm{H}$ amlet, Shakespeare confirmed that art holds "a mirror up to nature" (3.2.23).

${ }^{13}$ Originally published in The Rambler, on 20th March 1750.
} 
that "N ature had been partial in bestowing on some better faces than others, Art was alike indulgent to all, and industriously supplied those defects she had left, giving some addition also to her greatest excellencies" $(2003,15)$. We may conclude that the well-established aesthetic theory that the author applies - favoring art over nature - is present also in the work of certain writers of the Restoration period and the eighteenth century.

The "maker" was aware of the theoretical tradition summarized in the concept of ut pictura poesis, ${ }^{14}$ as evident in other works such as Oroonoko; or the Royal Slave, in the dedicatory letter of which the author draws a comparison between the poet and the painter, suggesting that "A poet is a painter in his way" (Behn 1997, 5). This serves to indicate that the content of a literary work should be a reflection of real life, an understanding similar to that presented by Samuel Johnson in the aforementioned reference. Comparing both types of creativity, Behn indicates that "the Pictures of the Pen shall out-last those of the Pencil" $(1997,6)$, confirming the writer's belief in the ability of literature to survive the passing of the centuries. The following section will examine an episode whose aesthetic background reflects this theoretical relationship.

\section{Female agency}

The rhetoric of disability, so central to the text as a whole, points to the concept of the gendered female by presenting Belvideera and Maria as a synecdoche. Maria's inability to speak is a metaphor for "the lack of social power accorded to women" (Pearson 2004, 200). According to Emily Bowles, "Behn crafts these narratives to amplify the corporeal practices to create femininity and thus draw attention

\footnotetext{
${ }^{14}$ The concept was established by Julius Caesar Simonides ( $5^{\text {th }}$ century $\left.\mathrm{BC}\right)$ through the idea that "painting is silent poetry, poetry eloquent painting." This declaration was written by Plutarch $(1878,1.50)$ in his M orals in these terms: "we first describe poetry [...] and tell [...] that it is an imitating art and doth in many respects correspond to painting; not only acquainting him with that common saying, that poetry is vocal painting and painting silent poetry," and "Though indeed Simonides calls painting silent poetry, and poetry speaking painting" (Plutarch $1878, \mathrm{~V}, 402$ ). This also calls to mind Scaliger's understanding of poetry, who echoed Horace's perspective (The A rt of Poetry. An Epistle to the Pisos, line 361), particularly concerning the topic of imitation. Similarly to Behn, Sidney had already determined poetry to be "a speaking picture" $(2002,86)$.
} 
to the ways in which femininity and femaleness are always already marked as defective" $(2012,2)$. The work develops a trope of female agency on various levels, both on aesthetic and creative terms as well as in the public and social spheres. ${ }^{15}$

Maria, the mute, is described as having the greatest skills and abilities in painting. When her father employs a renowned Italian artist to paint her portrait, after trying several times he gives up, unable to reproduce the brilliance of her gaze. The narrator details how, in response to the "weakness of the Painter," Maria "took up his Pencils and the Picture, and sitting down to her glass finished it her self" (345). This episode is an explicit example of female selfrepresentation, both figuratively and in a literal sense. The writer employs the powerful image of painting to reflect how the protagonist, incapable of speech, is nonetheless capable of applying her own unique set of skills and in so doing far surpasses the comparably poor attempts of a professional male artist.

Through this episode, the author points to several key principles. Firstly, she establishes that by the simple fact of being a woman, Maria is not incapable of creating a near-perfect work of art; in fact the painting she produces is far better than the attempts made by the professional painter her father had hired. Secondly, the writer makes a case for female activity as opposed to passivity. Maria embodies the idea of female-authored behavior, whose function is to break up and change the paradigm of femininity within the established cultural framework. The angelic young woman attains perfection through her skill with the brush. This passage is evidence of the prolificacy of Maria within the narrative as well as the prolificacy of the author as a writer, the works of the pen being comparable to works of art according to the author's aesthetic understanding discussed earlier.

The episode takes place at an internal level, within a domestic environment. However, the second episode that conveys female agency occurs externally to the domestic setting; specifically, at a

\footnotetext{
${ }^{15}$ The case of Celesia in "The Unfortunate Bride" is comparable, since it also tells the story of a blind heroine. Celesia's blindness also subverts normality and yet is portrayed as being somewhat beneficial. Her blindness is compensated by her ability to act as a guide to the protagonists, due to her mental and premonitory capacities, which surpass the physical sight of others, "for she saw clearly in her mind" (Behn 1995, 327).
} 
public celebration. Both Belvideera and Maria attract the attention of eligible gentlemen whom they meet at the ball they both attend. The novelistic employment of masquerade contains a heightened narrative potential that threatens patriarchal structures (Castle 1986, 4; Seager 2012, 79). The act of attending a masked ball is significant because it is another example of the author's depiction of active female behavior. This deduction should be considered with an emphasis on the fact that the protagonists do not represent the "normalized body."

The symbolic force of the appearance of the two disabled sisters in the middle of a social occasion is further emphasized in light of Congreve's account of a social event: "Everybody appeared well shaped, as it is to be supposed; none who were conscious to themselves of any visible deformity would presume to come thither." Congreve $(2003,15)$ in Incognita is describing a courtly masked ball, which also took place in Italy: notably, he directly excludes anyone with any kind of visible deformity. So, if anyone "conscious [...] of any visible deformity would presume" not to go to the celebration, following this stereotypical belief Maria and Belvideera should not have attended the ball. This highlights the boldness and the courage of the women in the story.

This episode calls into question the gendered roles to be assumed in a "Ball" and "Masquerade." In this context, Belvideera conceals her defects by disguising herself in men's clothes. ${ }^{16} \mathrm{~A}$ young Italian man quickly falls for Belvideera. When the protagonist speaks with the Courtier, he praises her sweet voice and "was entirely captivated with her wit" (346). The second remarkable occurrence is that another young man approaches Maria but, before he attempts to engage her in conversation, her sister Belvideera interrupts him, saying that Maria has taken a penance to remain silent. At this the young gallant responds "whoever impos'd silence on these fair lips, is guilty of a greater offense" (347).

Interestingly, it is Belvideera, aware of the social exclusion suffered by people with differing capacities, who takes it upon

\footnotetext{
${ }^{16}$ It is worth clarifying here that the appeal of the "masked ball" is that it allows characters to appear anonymized (Seager 2012, 788), their identities protected by their costumes. In this way, there is a degree of blurring or subversion of the traditional, ideological distinction of gender and class (Castle 1986, 55).
} 
herself to justify and conceal her sister's muteness from the young man. With regard to Maria's situation, the narrator's phrase "she agreed by paying the Price of her liberty" (347) is particularly revealing. In the ensuing conversation, one of Belvideera's responses is also very illuminating. She comments to the young Venetian on "the honor of being subdued by Ladies, we scorn mean praises" (347). With this phrase, the deformed protagonist represents women at the very pinnacle of the social hierarchy. The rigid demarcations of "the social contract" and "the sexual contract" (Armstrong 1987, 30) are being destabilized through the ideas presented by Belvideera. Through her fictional construct, the writer is challenging the social construct.

A nother illustration of female heroism occurs in the protagonists' house. The young man visits the house at the invitation of Rinaldo, who is unexpectedly called away to the Senate. Dangerfield encounters Maria in the library, where Rinal do tells him to entertain himself until he returns. In this scene, the two declare their love for each other and $\mathrm{M}$ aria, tormented by her inability to speak, decides to express herself through two brief lines of writing. Rinaldo declares: "I love you Madam to that degree, that if you leave me in a distrust of your anger, I cannot survive; I beg, intreat, conjure you speak, your silence torments me worse than your repproaches cou'd." Maria "moving towards a Writing Desk [...] took Pen and Paper, writ two lines" (353). The way in which the protagonist delivers her confession to her beloved is significant since she hands him the folded paper and retreats quickly from the room in shame ("flinging from him ran up to her chamber"). ${ }^{17}$ Her text reads: "You can't my pardon, nor my anger move.| For know, alas, I'm dumb, alas I love" (353). This episode presents two important ideas; firstly, the declaration of love on the part of the young woman and secondly, the revelation of her disability. Dangerfield's reaction is also significant in the forcefulness of his response and for the aesthetic

\footnotetext{
${ }^{17}$ The library setting ("a fine Library") (351-42) and Maria's writing are highlighted here as two key symbols in the text as a whole. The first is initially presented as a place of education and study for the young women, which her father has used to educate his daughters. The second presents the categorization of women as cultured and capable of writing and communicating with others outside the domestic sphere; capable of making decisions in matters of love, thereby suggesting a new conception of gender and new roles for women within society. Once again, the force of this image is enhanced by the protagonist being dumb.
} 
concept that it contains: "Dumb [...] naturally Dumb? O ye niggard powers, why was such a wondrous piece of Art left imperfect?" (353-54) once again explicitly pointing to the ideas of nature and art.

\section{Female possibility as a new conception of disability}

Femininity as a social construct is destabilized and subverted by the loyalty shown by the author's female protagonist to her own principles and the dictates of her own heart. Some critics have argued that this fiction "celebrates female virtues" (Pearson 1988, 150). Maria, Belvideera and their mother are the embodiment of female rebellion, a protest against female passivity. The way in which this is ultimately achieved is by choosing to represent themselves in society and by following their own desires rather than conforming blindly to the rigid rules that constrict femininity. In order to ensure the realization of their goals they must "transgress" the rigid and deeply rooted social conceptions of gender.

The examples given are textual representations of the protagonists' self-realization, which present a new understanding of deformity and disability. This understanding allows for a categorization of deformity as an active condition, and one in which individuals are capable of novel and constructive behavior. As Rosemarie Garland-Thomson has put it, "feminist disability studies question the dominant premises that cast disability as a bodily problem to be addressed by normalization procedures rather than a socially constructed identity" $(2005,159)$.

Within this paradigm, we may conclude that the tale presents the idea of "nonstandard bodies" as something beneficial, as a "transformity newness" (Garland-Thomson 2010, 201), as a "variability" (Mounsey 2014, 17), a viewpoint supported by Hay (2004, 24), who declared that "Bodily Deformity is visible to every Eye; but the Effects of it are known to very few." In this narrative, the effects are represented by female potential and agency. It may be concluded that the author of the tale stands as a forerunner in this field of literature, which displays physical deformities as powerful gifts or protean capabilities.

"The Dumb Virgin" deconstructs the established status quo with respect to female desire, as well as with regard to the development, 
involvement and depiction of women in society. It also subverts other deeply-rooted social customs, since the two daughters do not hide from the public eye as might be expected, secluded in the safety of the home as a result of Maria's muteness and Belvideera's physical deformity; instead, they actively pursue a life among high society. These defects do not prevent the young women from pursuing their desires, nor serve to deter their potential suitors. In this way, the writer formulates a wholehearted defense of the right of all women to a social life of their choosing, as she depicts one woman with physical deformities and another who is mute, yet who are still capable of contracting a marriage (N ussbaum 2000, 38). Female agency requires a courageous woman to attack the established social reality; nonetheless, the pursuit of her personal ambitions ends in tragedy.

\section{Tragic ends: M aria's suicide and Belvideera's reclusion}

Towards the end of the story several crimes are committed which are the first stages leading to the tragic conclusion. Dangerfield is murdered by a suitor of Belvideera called Gonzago. In his final moments, Dangerfield accidentally kills Rinaldo, while attempting to kill another character called Erizo. ${ }^{18}$ Finally, Maria takes her own life. The fact that these deaths occur in such quick succession is striking, and undoubtedly has a resounding impact on the reader. The circumstances surrounding Maria's suicide are deeply macabre; her death is preceded by a vision of the male protagonists, minutes from death, lying on the ground in a pool of their own blood.

\footnotetext{
${ }^{18}$ Particularly remarkable is the parallel that can be seen between this scene defined by the narrator as "fatal errour" $(358)$ and other works that were printed but not published in 1698. The same climax also appears in "The Unfortunate Bride" when Wildvill resolves to kill Frankwit but kills Belvira by mistake, "missing his Bride." The narrator defines it as a "fatal misunderstanding" (Behn 1995, 334). In "The Unhappy Mistake," Lewis Constance cries "O bloody Mistake!" (Behn 1995, 423) when Miles Hardyman deals him a fatal blow, having mistakenly taken him to be a rival for the love of Diana Constance. In O roonoko, when the protagonist kills his wife Imoinda and is discovered by the group of forty people who are searching for him, they cry out: "Oh, monster! that hast murther'd thy Wife" (Behn 1997, 62). In this case, Imoinda"s murder is not carried out in error but consciously and intentionally committed. There is no confusion or misunderstanding, which sets it apart from the aforementioned scenes. Nevertheless, there are noticeable parallels in terms of the murder itself and in the reaction of the group of onlookers.
} 
A nother pivotal moment occurs when Rinaldo, also lying fatally wounded on the ground, notices a birthmark on Dangerfield's neck and realizes that he must actually be his son (originally named Cosmo) who was believed to have drowned in the Adriatic Sea whilst travelling with his mother. The tragic nature of the situation is expressed by the long-lost son and lover of his sister when he cries out "O ye impartial powers [...] why did you not reveal this before? Or why not always conceal? How happy had been the discovery some few hours ago, and how tragical is it now?" (358-59).

Maria loses her father, her lover and her honor, "all at once" (358). The punishment she receives is colossal and is illustrated in a contrasting manner. The pleasure that the protagonist had previously enjoyed when making love with Dangerfield, described as "the greatest extasy of bliss" (357), has now become the direst tragedy. Belvideera describes the events as an "unfortunate history" (358). Maria, on the other hand, is overcome with suffering and "by a violent impulse broke the ligament that doubled in her Tongue, and she burst out with this exclamation: Oh! Incest, Incest" (359). Dangerfield echoes Maria's cries with "O! horror, horror, I have enjoyed my Sister, and murdered my Father" (359). Following this, the protagonist "plung'd it [Dangerfield's sword] into her Heart" (359). It is significant that Maria recovers from her disability in this dramatic moment and that she does in fact die with a fully functional, normalized body. Maria took great pleasure and satisfaction from life while she was dumb, but at the point when her disability disappears, her life becomes a tragedy. Maria loses her inability to speak after witnessing the fatal events occurring between her father and her lover, and upon realizing that she has committed an act of incest with her brother. It follows that Maria begins to speak as a result ${ }^{19}$ of the extreme trauma she suffers (the "violent impulse").

Belvideera's story also ends on a mournful note, as she decides "to maintain her a Recluse all the rest of her life" (360). The other protagonist condemns herself to reclusion, to a life of suffering and solitude within a melancholic domesticity and the interior world of the home. The conclusion to be drawn is that Maria commits suicide

\footnotetext{
${ }^{19}$ The same cause and effect can be seen in "The Unfortunate Bride" when Celesia recovers her vision after witnessing the tragic death of her cousin (Behn 1995, 334).
} 
and Belvideera becomes a recluse for the rest of her life; one sister takes her own life, the other retreats from life. At this point, they truly are the ones to decide their future. The protagonists choose to remove themselves from the social sphere, knowing their misfortune and the disastrous results of their female desirability and their unconventional behavior.

Analyzed in its entirety, it is possible to see how punishment is meted out to women both at the beginning and at the end of the story. According to the semantic argument that we have been following, these are punishments inflicted upon women who have broken free from the established social order, leaving the domestic sphere behind them and abandoning their position of marginality. First, the mother's punishment was the loss of her son Cosmo, followed by the deformity and the disability of her two daughters as well as her own death during childbirth. Subsequently, the punishment of the two daughters becomes evident. The punishment of the dumb sister who participates in social life (the masked ball, pleasure, ecstasy, Bliss) is death. The punishment of the deformed sister who also attempts to pursue her own desires is loneliness and seclusion.

The end of the text presents a tropic notion of female displacement. The two women withdraw from society, one through suicide, the other by self-imposed reclusion. This elimination is enforced by themselves because they are aware of the ostracism and the stigma that they would certainly suffer were they to remain, having "invaded" the territory of the male and of virtuous women of quality, being themselves "distorted" and "dumb." Belvideera chooses a life of total isolation; the stigma suffered by her sister would be far greater, since she also committed incest with her brother, al beit unknowingly. Therefore, Maria chooses death, and takes her own life.

The tragic aspect of the story which counterbal ances the narrative cannot be ignored. Maria (whose courage and ability are comparable to those of her mother) is the embodiment of the educated woman, and as such, she represents a direct threat to the established order. For this reason, the story is bound to come to a bleak conclusion; in this particular short fiction the woman who poses a menace to patriarchal society meets with a tragic, untimely death. Whatever is 
monstrous must be destroyed: and so, both the mother and daughters either die or end tragically.

Tragedy dominates the story's conclusion; such a bleak ending may well be interpreted as a morally justified result, deconstructing as it does the foundations established by the narrator over the course of the narrative, while simultaneously obliterating the positive impact of this mute, al beit eloquent, woman. This is the damning result of female expression in society (Craft-Fairchild 1993, 34). On the one hand, the young woman's education and exercitatio is consolidated; ultimately, however, the interference of Dangerfield, a symbol of masculine energy, makes it impossible for this model of female self-determination to survive. The protagonist's tragic and untimely death is inevitable. From the point of view of the patriarchal establishment, the existence of a woman capable of overcoming the natural limitations imposed upon her is such a grave threat to the status quo that it becomes necessary to destroy her. Nature abhors what is monstrous; as an educated woman, she is therefore just such a monstrosity, and for this, she must die. ${ }^{20}$

\section{The role of the narrator}

The role of the narrator deserves further attention in terms of the diverse forms in which is manifested within the story. At various times, the narrator takes the form of a character in her own right, as an eyewitness to key occurrences and as a writer who recounts the story in her own words. Firstly, it is worth noting that it is a female who narrates the story of Maria and Belvideera, a fact which stands in direct opposition to the hegemonically masculine literary discourse of the period. The narrator explains the deformity of the two female protagonists, pointing out the mother's culpability in this respect (following contemporary lines of thought): "which attributed to the learn'd the silence and melancholy of the Mother, as the deformity of the other was the extravagance of her frights" (344).

\footnotetext{
${ }^{20}$ Ardelia, in "The Nun: or, The Perjur'd Beauty," fights her confinement in the Monastery, against her father's will. She tries to remain true to her feelings, to her liberty and her freedom. A parallel can also be drawn between the climax of the two stories, since they both end in tragedy, with the death of the protagonist. Ardelia is subsequently referred to as "the late Fallen Angel" (Behn 1995, 311).
} 
The narrator appears within the fictional landscape alongside the protagonists: "Belvideera [...] was particularly pleas"d with the English which gave me the happiness of many hours of conversation with her" (344), confirming how she would regularly engage Belvideera in conversation in English, as well as being a witness to other events within the narrative. Speaking of Maria, the narrator reveals: "I remember this Lady was the first I saw use the significative way of discourse of the Fingers" (345). In this way, the narrator gives a direct, first-hand account of the details of the plot, which gives a sense of verisimilitude to the content of the story. She reappears towards the end of the narrative $e^{21}$ as a secondary character, ${ }^{22}$ a writer living close to Rinaldo's family_-"lodged within three doors of Rinaldo's House' (359), awakened by the cries of the neighborhood following the violence that erupts between Dangerfield, Rinaldo, Erizo and Gonzago. In his last moments, Dangerfield asks the female author to refer to his story by the term "Misfortunes" rather than "Crimes." In so doing, the male protagonist emphasizes the accidental nature of his "fate," ignoring the sense of wrongful action or punishment implied by the noun "crimes." The writer wishes to have "done him the Justice [...] to make him be pity'd for his misfortunes, not hated for his crimes" (359-60). The literary "maker" seeks to draw out the reader's compassion and to encourage them see these horrific consequences as an inevitable outcome.

The narrator describes herself as a writer in another passage in which she declares regarding one of the protagonist's names: ${ }^{23}$

\footnotetext{
${ }^{21}$ This is an example of a homodiegetic narrator (Genette 1972, 252) in the sense that she is in some way involved in the events being recounted (Abbott 2002, 64), lending them an imago veritatis.

${ }^{22}$ Backscheider $(2000,13)$ points to the authorial strategy (followed by Barker and Manley) of inserting their voice and certain autobiographical elements into their own works, concluding, "I see this characteristic as a deliberate strategy and an important, evolutionary step in the history of the English novel." Figueroa-Dorrego argues that this interference ensures the credibility, veracity and interest of the events narrated and concludes, "at no point are they capable of altering events to avoid the final tragedy" $(1999,49)$.

${ }^{23}$ In Oroonoko the narrator has a similarly multi-faceted role within the story (the female narrator is an eyewitness to specific events, as well as being a character within the narrative and the writer of the tale itself). A notably similar device occurs when the narrator confirms that one of the characters she meets over the course of the narrative appears in another of her comedies: "We met on the River with Colonel
} 
"Dangerfield, which was a name that so pleas'd me, that [...], I us'd it in a Comedy of mine" (348). She also reveals her nationality to be English at other points in the narrative, such as when she refers to a young Englishman as "my countryman" (345) and later by saying: "I began to mistrust my Englishman" (346). In this way, the distinction between "subject" and "subjected" becomes clear. Ros Ballaster has established the dual functions of the narrator who "represented simultaneously subject (the female writer) and subjected (the female character) within the social order, [as] a register of confusion, as well as an attempt to resolve it" $(1993,189)$. Nussbaum points out that "the narrator, herself a playwright, 'struck dumb by the horror of such woeful object' is herself made speechless when the heroine's tongue is loosened" (2003, 29). This anomaly complicates the otherwise neat relation between femininity and disability identified within the tale.

The narrator's initial appearance as a character creates a contrast between her "ableism" and the "nonstandardness" of Belvideera and Maria, although the last time she features directly in the narrative as a character she suffers a disability similar to that experienced by the female protagonists (ars). Nevertheless, the narrator undoubtedly personifies the idea of "sameness" or "ableism" in contrast to the deformity and disability of Belvideera and Maria.

In this way, the narrator alone (in contrast with Belvideera, Maria and their unnamed mother) is not directly associated with disability and deformity. However, as a character the narrator suffers disabling and paralyzing effects upon witnessing "the pathetic murder scene" (N ussbaum 2003, 32) at the climax of the story. The narrator factors into the dual concepts of natura and ars. The narrator, as an individual possessing ingenium (natura) inhabits a normalized body; however, when she features as a character in her own creation (ars), intervening directly in the social environment she has created, she becomes disabled precisely when she witnesses the

Martin [...], and whom I have celebrated in a Character of my New Comedy, by his own Name, in memory of so brave a Man" (Behn 1997, 57-58). This character, Martin, appears later as the protagonist of The Y oung Brother, or The A morous Jilt. However, it must be noted that the character of Dangerfield does not appear in any other of Behn's works. Todd suggests "she may be referring obliquely to The Rover which was based on Thomas Killigrew's Thomaso, The Wanderer since Dangerfield supposedly called himself Tomazo when he wrote his picaresque narrative of his adventures across England and Europe (D on Tomazo, published in 1680)" (1995, 464). 
tragic climax of her protagonists' story. Therefore, it is possible to conclude that the four female participants in the narrative (Belvideera, Maria, their mother and the narrator-character) all end tragically.

And yet despite this, it is to be inferred that the female presence in the story represents a defense of femininity; the characters themselves, as protagonists, uphold the notion of the free expression of female nature. At the same time, this female presence faithfully reflects contemporary reality, in that the tragic ends of the protagonists symbolize the consequences of active female engagement in the public sphere. The narrator-character's final appearance and her transition from normality to disability corroborate this theory that any woman who attempts to participate in social life either becomes marginalized or is eliminated entirely from society. The fact that the narrator is a woman represents a further defense of femininity, being an implicit proclamation for female literature and the status of the female writer. The indication is that while social parameters may restrict or silence women as actors within the social sphere, women writers-and their literary creations-persist and survive through the creative discourse that they develop.

\section{Conclusions}

From the outset, the concept of femininity is presented as deformed or disabled. The mother's unconventional behavior leads to her conceiving two children who are both in some way deformed. In order to achieve her purpose - one of social criticism and defense of the female - this master trope of deformity and disability should be understood as a synecdoche for femininity, both in terms of its representation and in the vindication of a greater female agency that is evident in the narrative. The anomalous female behavior portrayed by the narrator-character confronts the prevailing concept of female nature, insofar as the behavior of Maria and Belvideera is utterly subversive of it. Within this understanding, abnormality of any sort (here taking the form of dumbness and "dys-ymmetry" [344]) should not threaten to destabilize the social order. Maria and Belvideera should remain passive, thereby preserving the purity of female perception within society. Yet it is precisely their attempts to 
work against nature that leads to the shifting of these natural conditions, through behavior that defies established customs and social convention. These "individual bodies" choose to defy societal and cultural mores.

It may be concluded that the writer favors ars over natura and makes the case for nature improved by art and rules. The author's "industry" ("industry of Art") is a precursor to Congreve's "indulgence" ("Art was alike indulgent [...] and industriously supplied those defects") and also anticipates Pope's "method" ("Nature Methodiz' $\mathrm{d}^{\prime}$ ). In "The Dumb Virgin," this methodus ( $\mu c \dot{\theta} \theta o \delta o \varsigma$, which etymologically suggests the idea of a path to be followed) means study, education and artifice as a means of surpassing natural disabilities. This literary text, besides being a fiction, is a discourse on the theory of literature.

By means of these strategies, the author intends to cause a shift in femininity mythologies. Breaking the normalized and stereotypical rules challenges the comfortable classifications of gender and morality. Female agency presents a new conception of deformity, one that is viewed as being less defective and more beneficial. Consequently, the perception of disfigurement that the writer develops reflects an epistemological journey over the course of the eighteenth century from defective disfigurement to beneficial deformity.

Nevertheless, the challenge to the social construct must end in tragedy. Maria commits suicide, and hers is not the only death resulting from her actions. The sisters' attempts to realize a form of female heroism end in a monstrosity of incest and violence. All the women of the story come to a tragic end, indicating that the employment of female potential and desirability motivated by female agency can only end in utter misery. This may be seen to reflect an understanding of female and gendered agency as monstrous and abnormal. Similarly, a body such as that of Belvideera, which is born deformed, must remain on the margins of society, confined to the interior world of the home, within the domestic sphere. Her attempt to break out into the outside world causes several important changes. It allows Belvideera and Maria to implement their own will and to fall in love. Essentially, it allows them to become active participants within society. This courage has a 
destabilizing effect on the established order; their expression of female courage threatens the cultural construct of femininity.

The text becomes a reflection of social conventions and a microcosm of the case for a new conceptualization of femininity. Written some decades before the publication of M illenium $\mathrm{H}$ all, "The Dumb Virgin" shares certain motivations with Hay. The tale of Maria and Belvideera had already created a feminized universe, proposing an active role for women within society and challenging or subverting the dominant patriarchal ideology and its concomitant gender inequality. Critical interest in "The Dumb Virgin" arises from its depiction of two disabled female protagonists and how the author uses their representation to argue for both a greater female agency and a reframing of the concept of the "normalized" body. The writer's originality and courage in showing how nature can be manipulated through art is a fundamental aspect of this "novel" (335). The "maker" promoted art and exercitatio over nature; at the same time her writing postulates a new conception of gendered femininity.

\section{References}

A bbott, H. Porter. 2002. The Cambridge Introduction to N arrative. Cambridge: Cambridge University Press.

Armstrong, Nancy. 1987. Desire and Domestic Fiction. A Political history of the N ovel. Oxford: Oxford University Press.

A usten, Jane. (1818) 2006. N orthanger A bbey. Edited by Barbara M. Benedict and Deirdre Le Faye Cambridge: Cambridge University Press.

Backscheider, Paula R. 2000. Revising Women. Eighteenth-century "Women's Fiction" and Social Engagement. Baltimore: The Johns Hopkings University Press.

Bacon, Francis. (1612) 2002. "Of Deformity." In The M ajor W orks including the $\mathrm{N}$ ew Atlantis and the Essays, edited by Brian Vickers, 426-27. Oxford: Oxford University Press.

Ballaster, Ros. 1993. "Pretences of State': Aphra Behn and the Female Plot." In Rereading A phra Behn: History, Theory, and Criticism, edited by Heidi Hutner, 187-211. Charlottesville: University Press of Virginia.

Behn, Aphra. (1700) 1995. "The Dumb Virgin; or, the Force of Imagination." In The W orks of A phra Behn. The Fair Jilt and Other Short Stories, Vol. III, edited by Janet Todd, 335-60. London: William Pickering. 
(1689) 1995. "The History of the Nun: or, The Fair-Vow-Braker." In The Works of A phra Behn. The Fair Jilt and Other Short Stories, Vol. III, edited by Janet Todd, 205-58. London: William Pickering.

(1698) 1995. "The Unfortunate Bride; or, the Blind Lady, A Beauty." In The Works of A phra Behn. The Fair Jilt and Other Short Stories, Vol. III, edited by Janet Todd, 321-34. London: William Pickering.

(1698) 1995. "The Unhappy Mistake; or, the Impious Vow Punish'd." In The Works of A phra Behn. The Fair Jilt and Other Short Stories, Vol. III, edited by Janet Todd, 411-42. London: William Pickering.

__ (1688) 1997. Oroonoko. Ed. Joanna Lipking. New York: Norton \& Company.

Blount, Thomas Pope. 1967 (1692). Essays on Several Subjects W ritten by Sir Tho. Pope Blount. London: Printed for Richard Bentley, in Russel-street in Covent-Garden.

Bowles, Emily. 2012. "Fatally Enjoy'd: Rape, Resilience, and the Accessibility in Aphra Behn's The Dumb V irgin." A BO : Interactive Journal for W omen in the A rts, 1640-1830 2: 1-14.

Castle, Terry. 1986. Masquerade and Civilization. The Carnivalesque in Eighteenth-Century English Culture and Fiction. London: Methuen.

Chico, Tita. 2000. D esigning Women. The D ressing Room in Eighteenth-Century English Literature and Culture. Lewisburg: Bucknell University Press.

Congreve, William. (1692) 2003. Incognita. Edited by Peter A ckroyd. London: Hesperus Press Limited.

Craft-Fairchild, Catherine. 1993. M asquerade and Gender: Disguise and Female Identity in Eighteenth-Century Fictions by Women. University Park: Pennsylvania State University Press.

Dryden, John. (1677) 2006. "The Author's Apology for Heroic Poetry and Heroic License." In The N orton A nthology of English Literature, edited by Stephen Greenblatt and M. H. Abrams, 2129-31. New York: Norton \& Company.

Elk, Martine van. 2017. Early M odern Women's W riting. Domesticity, Privacy, and the Public Sphere in England and the Dutch Republic. London: Palgrave Macmillan.

Fielding, Henry. (1742) 1980. "Preface." In Joseph A ndrews and Shamela, edited by Douglas Brooks-Davies, 3-9. Oxford: Oxford University Press.

Figueroa-Dorrego, Jorge. 1999. A phra Behn (1640-1689). Madrid: Ediciones del Orto.

Fuchs, Barbara. 2004. Romance. New York and London: Routledge.

Garland-Thomson, Rosemarie. 2002. "Integrating Disssability, Transforming Feminist Theory." M WSA Journal 10: 1-32. 
—_. 2005. "Feminist Disability Studies." Signs 30 (2): 1557-87.

_ 2010. "Beholding." In The D isability Studies Reader, edited by Lennard Davis, 199-208. New York: Routledge.

Genette, Gérard. 1972. Figures III. Paris: Éditions du Seuil.

Habermas, Jüngen. 1989 (1962). The Structural Transformation of the Public

Sphere: An Inquiry into a Category of Bourgeois Society. Translated by

Thomas Burger and Frederick. Cambridge: The MIT Press.

Hay, William. (1754) 2004. D eformity: A n Essay. Edited by Kathleen JamesCavan. Victoria BC: University of Victoria.

Horace. 1783. The Art of Poetry. Epistle to the Pisos. Translated by George Colman. London: T. Cadell.

James-Cavan, Kathleen. 2005. "[A]ll in Me is Nature." Prose Studies 27 (1-2): 27-38.

Johnson, Samuel. (1779-81).1984. "Pope." In Samuel Johnson. The Oxford Authors, edited by Donald Green, 725-52. Oxford: Oxford University Press.

. (1750) 2008. "The Rambler, no. 4 [The New Realistic Novel] (1750)." In Samuel Johnson. The M ajor W orks including Rasselas, edited by Donald Greene, 175-78. Oxford: Oxford University Press.

McKeon, Michael. 2005. The Secret H istory of D omesticity. Baltimore: The John Hopkins University Press.

_ 2017. "The Eighteenth-Century Challenge to Narrative Theory." In $\mathrm{N}$ arrative Concepts in the Study of Eighteenth-Century Literature, edited by Liisa Steinby and Aino Mäkikalli, 39-77. Amsterdam: Amsterdam University Press.

Mintz, Susannah. 2006. "Freak Space: Aphra Behn's Strange Bodies." Restoration 30 (2): 1-19.

Mounsey, Chris. 2014. "Introduction." In The Idea of Disability in the Eighteenth Century, edited by Chris Mounsey, 1-27. Plymouth: Bucknell University Press.

Nussbaum, Felicity. 1997. "Feminotopias: The Pleasures of 'Deformity' in Mid-Eighteenth Century England." In The Body and Physical Difference: Discourses of Disability, edited by David Itchell and Sharon L. Snyder, 161-73. Ann Arbor: The University of Michigan Press.

—. 2000. "Dumb Virgins, Blind Ladies, and Eunuchs: Fictions of Defect." In "Defects": Engendering the Modern Body, edited by Helen Deutsch, and Felicity Nussbaum, 31-53. Ann Arbor: The University of Michigan Press.

2003. The Limits of the Human. Fictions of A nomaly, Race and Gender in the Long Eighteeth Century. Cambridge: Cambridge University Press. 
O'Donnell, Mary Ann. 2004a. "Aphra Behn: The documentary record." In The Cambridge Companion to Aphra Behn, edited by Derek Hughes and Janet Todd, 1-11. Cambridge: Cambridge University Press.

2004b. "Chronology." In The Cambridge Companion to A phra Behn, edited by Derek Hughes and Janet Todd, xi-xxii. Cambridge: Cambridge University Press.

Orr, Leah. 2013. "Atribution Problems in the Fiction of Aphra Behn." M odern Language Review 108 (1): 30-51.

Pearson, Jacqueline 1988. The Prostituted M use. Images of Women \& Women dramatists 1642-1737. New York: St. Martin's Press.

- 2004. "The short fiction (excluding O roonoko)." In The Cambridge Companion to A phra Behn, edited by Derek Hughes and Janet Todd, 188203. Cambridge: Cambridge University Press.

Plutarch. 1878. M orals. Translated from the Greek by Several Hands. Corrected and Revised by William W. Goodwin, with an Introduction by Raph Waldo Emerson. 5 vols. Boston: Little, Brown and Co.

Pope, Alexander. (1711) 2008. An Essay on Criticism. In Alexander Pope. Selected Poetry, edited by Pat Rogers, 1-20. Oxford: Oxford University Press.

Pratt, MarieLouise. 1992. Imperial Eyes: Travel Writing and Transculturalization. London: Routledge.

Reeve, Clara. 1785. The Progress of R omance, through times, countries, manners; with remarks on the good and bad effects of it on them respectively, in a course of evening conversations. 2 vols. Colchester: W. Keymer.

Robitaille, Marilyn. 1997. "Patterns of Iconicity in Aphra Behn's The Dumb Virgin, Or the Force of the Imagination." Conference-of-College-T eachers-ofEnglish-Studies, Alpine, TX (CCTEP), Sept. 62: 1-10.

Scaliger. 1905. Select Translations from Scaliger's Poetics. Edited by Albert S. Cook. New York: Henry Hork and Company.

Scott, Sarah. (1762) 1995. M illenium Hall. Edited by Gray Kelly. Peterborough: Broadview Press.

Seager, Nicholas. 2012. The Rise of the Novel. A Reader's Guide to Essential Criticism. London: Palgrave.

Shakespeare, William. (1623) 2007. The Winter's Tale. Edited by Susan Snyder and Deborah T. Curren-Aquino. Cambridge: Cambridge University Press.

—_. (1603) 2014. Hamlet. Edited by Philip Edwards. Cambridge: Cambridge University Press.

Sidney, Sir Philip. (1595) 2002. A n A pology for Poetry (or The D efense of Poesy). Edited by R. W. Maslen. Manchester: Manchester University Press. 
Todd, Janet. 1995. "The Dumb Virgin." In The W orks of A phra Behn. The Fair Jilt and O ther Short Stories. Vol III, edited by Janet Todd, 336-37. London: William Pickering. . 1996. The Secret Life of A phra Behn. London: André Deutsch.

Torralbo-Caballero, Juan de Dios. 2015. "'The Greatest Extasy or Bliss': Realism, Subversion and Eroticism in The Dumb Virgin; or The Force of Imagination." Revista Canaria de Estudios Ingleses 71: 143-62.

Trofimova, Violetta. 2011. "Magic and Irrationalism in Aphra Behn's and Jane Barker's Prose Fiction." In A phra Behn and Her Female Successors, edited by Margarete Rubic, 109-19. Berlin: Lit Verlag.

Yao-Hsi, J. Shih. 2014. "Fancy, Gender and Race in Aphra Behn's The Dumb Virgin and The U nfortunate Bride." Hikma 13: 173-92.

How to cite this article:

Torralbo Caballero, Juan de Dios. "“For know, alas, I'm dumb, alas I love': Rhetoric of disability, female agency and tragedy in 'The Dumb Virgin'." SEDERI 27 (2017): 167-92.

A uthor's contact: torralbocaballero@uco.es

Postal address: Dpto. Filologías Inglesa y Alemana - Facultad de Filosofía y Letras Plaza Cardenal Salazar, s/ n - 14071 Córdoba, Spain. 


\title{
Book culture in the Irish mission: The case of father Juan de Santo D omingo (1636-1644)*
}

\author{
Cristina Bravo Lozano \\ U niversidad Pablo de O lavide, Spain
}

\begin{abstract}
The Irish Mission was created in 1610, under the sponsorship of the Spanish monarchy, to preserve Catholicism in the British Isles. The training of priest and friars was heavily reliant on the use of bibliographic material. Short manuscripts, books and printed writings were supplementary tools for the missionaries' confessional work. Their pastoral duty could not be completed without access to readings and sermons. All these resources had to be smuggled as part of other merchandise to avoid the English control. The supply of doctrinal and theological works, chiefly from the Iberian Peninsula and the Spanish Low Countries and their commercial channels, was, however, beset by constant problems. It was the case of father Juan de Santo Domingo and his shipment of books seized in Bilbao in 1636. This study presents one of the few examples of circulation of texts between the Spanish monarchy and Ireland in the framework of the Irish Mission during the seventeenth century.
\end{abstract}

KEYWORDS: book dissemination; Irish Mission; Ireland; Spain; Flanders.

La cultura del libro en la Misión de Irlande: el caso del padre Juan de Santo Domingo (1636-1644)

RESUMEN: La Misión de Irlanda fue creada bajo el patrocinio de la monarquía de España para la conservación del catolicismo en las Islas Británicas. La formación de sacerdotes y religiosos encontró

\section{Cultura Livresca na M issão de Irlanda: 0 Caso do padre Juan de Santo D omingo (1636-1644)}

RESUMO: A Missão de Irlanda foi criada em 1610, com o patrocínio da monarquia espanhola, de maneira a preservar o catolicismo nas Ilhas Britânicas. A instrução de padres e frades dependia forte-

\footnotetext{
* This study has been undertaken thanks to funding from Juan de la Cierva-Formación (FJCl-2014-21225) and two projects funded by the Dirección General de Investigación del Ministerio de Economía y Competitividad: El modelo policéntrico de soberanía compartida (siglos XVI-XVIII): una vía alternativa a la construcción del Estado moderno (HAR2013-45357-P) and Sociedad cortesana y redes diplomáticas: la proyección europea de la monarquía de España (1659-1725) (HAR2015-67069-P MINECO/ FEDER). I am grateful to David Govantes-Edwards for the translation of this text.
}

Abbreviations: AGS=Archivo General de Simancas (Simancas, Valladolid); AHN=Archivo Histórico Nacional (Madrid); ASPF=Archivio Storico di Propaganda Fide (Rome); TNA: PRO=The National Archives: Public Record Office (Kew).

** Translation into Portuguese by Miguel Ramalhete. 
en los materiales bibliográficos un soporte fundamental. En ese sentido, pe queños manuscritos, libros y textos impresos actuarían como instrumentos auxiliares en su aplicación confesional en aquellos reinos. Por ello, su obligación pastoral se vio reforzada con el acceso y utilización de las lecturas y los sermones. Estos recursos se introducían de forma disimulada, confundidos con otras mercancías, para sortear el control de las autoridades inglesas. La provisión de obras doctrinales y teológicas, remitidas desde la Península Ibérica y los Países Bajos españoles, principalmente, no estuvo exenta de dificultades. Este fue el caso de fray Juan de Santo Domingo y su cargamento de libros, detenido en Bilbao desde el año 1636. Dada la dificultad de hallar fuentes al respecto, el objeto del presente estudio es presentar uno de los pocos ejemplos acerca de la circulación de textos enviados por la monarquía de España hasta Irlanda en el contexto de la Misión durante el siglo XVII.

PALABRAS CLAVE: circulación del libro; misión irlandesa; Irlanda; España; Flandes. mente do uso de material bibliográfico. Pequenos manuscritos, livros e textos impressos eram ferramentas complementares para o trabalho confessional dos missionários. $\mathrm{Na}$ verdade, o seu dever pastoral não estava completo sem acesso a leituras e sermões. Todos estes recursos tinham de ser contrabandeados no meio de outras mercadorias de modo a evitar o controlo britânico. A provisão de obras doutrinais e teológicas, vindas sobretudo da Península Ibéria e dos Países Baixos espanhóis assim como dos seus canais comerciais, estava, contudo, assolada por problemas constantes. Foi este o caso do Padre Juan de Santo Domingo e do seu carregamento de livros intercetados em Bilbao desde 1636. Este estudo apresenta um dos poucos exemplos da circulação de textos entre a monarquia espanhola e a Irlanda no contexto da Missão Irlandesa durante o século XVII.

PALAVRAS-CHAVE: circulação de livros; missão irlandesa; Irlanda; Espanha; Flandres.

In 1644, the Irish father Juan de Santo Domingo, Procurator General of the Dominican order, asked Philip IV to send 200,000 books, at the expense of the royal finances to disseminate "our holy faith in England, Ireland and Scotland." 1 They were made ready for shipment in the port of Bilbao, taking advantage of the ascendancy of the Confederation of Kilkenny and the favorable conditions that this offered for the Catholic religion. Once there, however, the custom officers raised a number of issues, and the books were detained in the harbor for three years. ${ }^{2}$

These texts were earmarked for the mission that the Spanish monarchy had been sponsoring in Ireland since 1610 (Bravo Lozano forthc.). The mission's goal was to mitigate the problems caused by

\footnotetext{
${ }^{1}$ For a general perspective on religious texts, see Bouza Álvarez (2006).

${ }^{2}$ A GS, Estado, leg. 2807. Consult of the Council of State. Madrid, 28June, 1644.
} 
emigration towards the Iberian Peninsula after the military fiasco of Kinsale (1601). This unsuccessful offensive against Elizabeth I forced Philip III to explore new ways of intervening in Ireland. Among other policies, confessional policies would come to the forefront. In 1610, a new initiative for royal patronage that involved the pension granted by the king to the archbishop of Cashel, David Kearney, began to take shape. The purpose of the 1,000 ducats per year assigned through the bishopric of Cadiz, ducats which were to be managed by the chaplain and almoner major Diego de Guzmán, was to send priests and friars to the British Isles in order to preach and administer the sacraments. The Irish colleges attached to Castilian and Portuguese universities, as well as the convents of the respective regular orders were in charge of ensuring that the missionaries underwent solid and comprehensive training. ${ }^{3}$ Following their vows and ordination, the missionaries started their voyage after a period of obligatory isolation, and carried with them a royal viaticum of 100 ducats to pay for the boat and secular clothes, liturgical ornaments and books (Bravo Lozano 2013). The latter, which were the keystone of the missionaries' education, were a complementary tool to aid them in their apostolic work (Gillespie 2005, 9).

The clandestine circulation of Catholic books in Ireland was common practice, avoiding the rules imposed by the Protestant government on the content and distribution of religious texts. In late medieval and early modern Ireland, in addition to being a vehicle for Irish secular culture, bardic poetry contained Christian interpretations which had been regularly employed as an instrument for religious instruction. ${ }^{4}$ Nevertheless, the importation and contraband of continental works, with updated religious views that adapted to the resolutions adopted in the Council of Trent, increased at the turn of the seventeenth century. Most of these new manuscripts and printed texts came from Flanders and circulated through ecclesiastic and other internal networks (Gillespie 1996; 1997, 155; 2005, 63).

Within this complex framework, father Juan de Santo Domingo's petition is one of the few documented examples of the dispatch of

\footnotetext{
${ }^{3}$ For the Irish colleges in the Iberian Peninsula, see O'Connell (1977, 2001, 2007); García Hernán (2006; 2012); Recio Morales (2004); and Fenning (2009).
}

${ }^{4}$ On the use of Gaelic texts in late medieval Ireland see Ryan (2011; 2013; 2015). 
books from the Iberian Peninsula to Ireland. This isolated testimony is indicative of the impact of the Catholic works sent from Spain to the island. It highlights the extraordinary relevance of literary culture and the multiple uses of reading in this "peripheral mission," but it also illustrates the logistical problems that deprived Irish clerics of such written material. ${ }^{5}$ This proselytizing activity aimed to transform social approaches to religion, from education in the domestic environment to general catechesis; from the ecclesiastical control of personal reading habits to guidance in the interpretation of the Bible; from the definition of a common confessional identity, where books acted as a key ideological tool, to the indoctrination of the priests and friars sponsored by the Spanish monarchy. However, it is difficult to assess the local distribution of the books, and indeed their cultural impact, in a society crisscrossed by great internal differences and defined by orality. It is also difficult to trace the missionaries involved, because the information available concerning the scope of their activities in Ireland is sparse, especially for some of the island's regions.

The urgent need to remove the impediments to Juan de Santo Domingo's work became obvious in 1636. At this time, the number of Catholic priests increased in England, but they were scattered throughout the kingdom. From 1618 onwards, the number of Episcopal appointments in Ireland also grew, following a series of promotions in Rome (Ó Hannracháin 2015, 39, 52-53). Despite these favorable religious circumstances, the imposition of tax by the Spanish monarchy, servicio de millones, which was collected by the custom offices in Bilbao and Vitoria, halted the passage of free books to the British Isles. ${ }^{6}$ These ports were among the main Spanish commercial links with northern Europe. Theoretically, the new religious conditions should have resulted in fewer difficulties and a speedy embarkation, but the fiscal measure came to alter the

\footnotetext{
${ }^{5}$ For a recent view of the issues surrounding books in early modern Catholicism, see the monograph edited by Maillard Álvarez (2014). For the bibliographic production of the English colleges in Castile and Flanders, see Bouza Álvarez (2002) and the volume edited by Cano-Echevarría and Sáez-Hidalgo (2009). Book culture was as important in the Irish Mission as it was in the better-known "interior missions." On the consumption of books by the peninsular "interior missions," see Palomo del Barrio (2011).
}

${ }^{6}$ For the tax of millones in the 1630s, see Gelabert (2001). 
situation. ${ }^{7}$ After the introduction of the tax, all merchandise was to be taxed at a rate of 30 reales per arroba ${ }^{8}$ ( 24 reales for custom duties and 6 for the tithe) and the loads of books were stopped and payment demanded of the mule drivers.

Indeed, this is what happened to five bundles and one chest of books, which were left in storage in the convent of the Santa Cruz (Segovia) while they waited to be sent to Ireland from Bilbao in 1636. The new royal tax meant that the price of sending the 1,220 arrobas of books rose by 3,660 reales-a price that neither the mule driver who had transported the books, Diego Ortiz de Montoya, nor the Dominicans were able to pay. ${ }^{9}$ These problems halted the shipment, which could not proceed past the port. This placed a heavy burden on the whole operation: "the muleteers cost dear, and the sea is less favorable, and the whole thing becomes more expensive." The only alternative for these friars was to appeal to Philip IV. The king could exempt them from the payment of the tax in order "that the number [of books sent to the Irish Mission] was not limited, until it could even be considered a little excessive."10

The question was examined by the Council of State. Attending to the reasons presented by the Dominican Procurator General, William Fitzgerald, and the aforementioned father Juan, the councilors asked them for the contents of the boxes. They wanted to verify that the shipment was really limited to books, as had been declared and no other products of contraband that could compromise the AngloSpanish relations. Without specifying the subject, father William indicated in the inventory that the boxes contained old and new copies "given as charity, for Mass." He also noted that some of them had been "bought by arrobas in bulk." After stressing that most of the volumes had been labelled well used, he highlighted how beneficial they would be to continue spreading the word in Ireland.

\footnotetext{
${ }^{7}$ On the commercial activity of the Basque ports, see García Fernández (2005).

${ }^{8}$ The arroba is an old unit of weight, which corresponded to $11.5 \mathrm{kgs}$ in Castile.

${ }^{9}$ The escribano real y del número of Vitoria, Juan de Ugarte, certified that the mule driver Diego Ortiz de Montoya did not pay the 30 reales per arroba for the printed books that he was transporting between Segovia and Bilbao, for which reason the books were left in Vitoria. AGS, Estado, leg. 2799. Certification of Juan de Ugarte. Vitoria, 4 July, 1636.

${ }^{10}$ AGS, Estado, leg. 2799. Father Juan de Santo Domingo to Philip IV. Segovia, 26 August, 1636.
} 
The ultimate purpose of the books was to assist preaching and the religious education of Catholics. Irish missionaries would use them as a complementary tool during their confessional and spiritual work. Their content was often politically charged and thus problematic, but they were only to be disseminated through communal readings and sermons directed by the priests and friars who carried them. In this context, particular note should be taken of the audience for which they were intended, and of how these practices could have a direct effect on the social structure, especially, among the geographically dispersed rural communities. In the seventeenth century, illiteracy was rife, and many learned religious values and prayers through preaching and ecclesiastical exegesis during the liturgy, the teaching of other, more learned, individuals, and imitation by example of local saints that stood as religious models (Gillespie 1997, 20-35; Cunningham 2014, 163). Nevertheless there were some people who could read, and convey different passages of the most widespread text, the Bible, to others. Catholics were compelled to practice their devotions privately and, indeed, use Catholic texts in their pious work of religious intercession (Gillespie 2005, 133-38; 2006, 23; Walsham 2000, 78). For all of these reasons, Philip IV adopted a pragmatic resolution and endorsed the petition, permitting the free embarkation of the books as an act of "charity."

Once the tax-related hurdles had been overcome, the next problem was to find ships to take the merchandise to Ireland. The active commercial networks based in the northern Spanish ports were involved in the transportation of missionaries and all kinds of products during the seventeenth century. Although the guards of the Customs Office searched the boats and freights, there were always merchants who were willing to take them secretly. However, after the military disaster suffered by admiral Antonio de Oquendo's fleet against the Dutch, the commercial flows of traffic were indirectly affected and the free circulation of vessels suffered accordingly. ${ }^{12}$ In 1641 , in conjunction with the rebellion in UIster, father Juan de Santo Domingo, now named Procurator General of his order, explained to Philip IV the problems involved in sending a new book shipment

\footnotetext{
${ }^{11}$ A GS, Estado, leg. 2799. Consult of the Council of State. Madrid, 16 September, 1636.

${ }^{12}$ For the context and the consequences of the battle of Dunas, see Alcalá-Zamora y Queipo de Llano (1975).
} 
that he had personally compiled. The first insurgent movement of the Irish Catholics (the Confederation of Kilkenny), however, opened new opportunities for their community. ${ }^{13}$ Despite the restrictions imposed by the English and the turbulent political context, attempts were made to rapidly resume the sending of Popish books between Spain and Ireland. However, trading ships became harder to come by due to the death of the Irish sailors who had once used their vessels to bring missionaries and forbidden merchandise to the British Isles. Owing to the ongoing political and religious developments, control measures became stricter and each ship and cargo was examined, especially around Dublin. The growing complications and need for confidentiality forced those involved to pay more for the boats to ensure that the vessels were not seized by the English authorities. Father Juan calculated an expenditure of 2,000 ducats-an amount that was, by all accounts, excessive-for this shipment, but the Spanish king had only provided him with 200 ducats. $^{14}$

At any rate, the amount requested from Philip IV in 1644 was again 2,000 ducats, in spite of the fact that the new shipment was much larger (it consisted of 200,000 books). The transport cost for this cargo-that is, excluding all other expenditures-was 2,000 ducats, according to the merchants of Bilbao. It is likely that while the issue was being resolved by the Council of State father Juan continued accumulating books for the Mission. He seemed to be persuaded of the importance of written texts for his enterprise. Faced with a more ambitious task, the Dominican procurator thought that he was justified in asking for the extra money to cover shipment costs. The Stuart ambassador at the Spanish court, Arthur Hopton, was aware of this situation, and informed London that the number of books collected by the friar was above 100,000 volumes, mainly consisting of devotional and instructional works. Although the matter was of great consequence to English interests, he was not able

\footnotetext{
${ }^{13}$ The Confederation of Kilkenny, within the context of the English Civil War, was an insurgent movement set up in 1641, when the Catholic elite and the ecclesiastic hierarchy of Ireland tried to take advantage of the circumstances and expel the English army on the island. It was terminated by Oliver Cromwell in 1649. There is plenty of literature about these events. Especially useful is Jennings (1959); Ohlmeyer (1995); Lenihan (1999, 2001); Canny (2001); Ó Siochrú (2005); Pérez Tostado (2008); and the volume edited by Ó Siochrú and Ohlmeyer (2013).
}

${ }^{14}$ A GS, Estado, leg. 2804. Consult of the Council of State. Madrid, 19 N ovember, 1641. 
to say whether royal funds were compromised, and he did nothing to complain to Philip IV about book circulation. ${ }^{15}$ Despite the diplomat's lack of information, the Spanish king had indeed conceded to father Santo Domingo 2,000 ducats, given the "pious" nature of the project. ${ }^{16}$ In addition, he crossed out any other costs by associating the shipment with the media anata of the "tithe of the sea" in Bilbao and other nearby ports in $1645 .{ }^{17}$ This new concession provided the Dominican with the means with which to pay the exportation expenses. These printed works were used to improve the Catholic position in Ireland, especially in the political context of the English Civil War and the progressive inclination of the Irish Catholics towards the royalist side.

In line with their stated missionary purpose, it was assumed that the bundles could contain doctrinal, theological and devotional works, breviaries, manuals for confessors, hagiographies and any text that helped to spread Catholicism. However, the record raises certain doubts concerning the content of the boxes: the books were purchased in bulk, and also there was a vast number of volumes. This suggests that the content of the books being carried to the Irish Mission was not restricted to religious topics; printed texts could, of course, be used to disseminate all kind of ideas. Concerning political issues, for instance, some texts appealed to religious tolerance, while others conveyed with controversial arguments and made apologies for the Holy See or espoused the role of the Spanish monarchy as the champion of Catholicism. At any rate, it is not possible to identify exact titles, the topics covered or the language in which these works were written; whether there were books in English, if catechisms in Gaelic, published in Flanders, were included, or whether there were volumes in Latin or in an European vernacular other than English. It is clear that the ultimate purpose of the project was to instruct Catholics through sermons, visual means and individual or

\footnotetext{
${ }^{15}$ TNA: PRO, State Papers, 94/ 42, ff. 164rv. Arthur Hopton to Henry Vane. Madrid, 24 A pril, 1641 (Pérez Tostado 2008, 29-30).

${ }^{16}$ AGS, Estado, leg. 2807. Consult of the Council of State Estado. Madrid, 28 June, 1644.

${ }^{17}$ AGS, Consejo y Juntas de Hacienda, leg. 884 [BD Misión de Irlanda, 1223]. Consult of the Council of Finances. Madrid, 8 February, 1645. Two days later, the monarch reiterated the order in favor of father Juan de Santo Domingo. AHN, Fondos Contemporáneos. Ministerio de Hacienda, L. 7890, f. 50r. Decree of Philip IV to the president of the Council of Finance. Madrid, 10 February, 1645.
} 
communal readings. Everyone involved was acutely aware of the potential of these works and the impact of bringing the written word to places where the voice of missionaries could not be heard (Walsham 2000, 76-77).

The books which were waiting for dispatch in Bilbao must be distinguished from those which were carried by the missionaries on their persons-books which were acquired in Spain with the viaticum of 100 ducats, because they were difficult to find in Ireland, where there were no printing houses. For smuggling purposes, these works were often small (sometimes nothing more than printed sheets) and easy to conceal from the English authorities. ${ }^{18}$ In other cases, they were short tracts, manuscripts or pamphlets published under other titles, but all of them contained the main doctrinal principles. Catechisms, such as those written by Bonaventure O'Hussey, Florence Conry or Theobald Stapleton, created a doctrinal framework and made the oral transmission of Catholic values easier (Gillespie 2005, 132). They approached religion in simple and clear language, and explained political ideas originating from the Continent, such as Irish loyalty to Rome and the defense of the Irish interests by the Spanish monarchy (Cunningham 2014, 155, 157, 159). Despite the power of this oral method of dissemination, messages thus conveyed were briefer than the Spanish Monarchy thought desirable for the purpose of consolidating Catholicism in the British Isles.

The documental traces left by these writings are limited, and their content was rarely discussed in the different consultations and memoranda. The only references allude to "apostolic and scholastic" volumes paid for with the royal prebend. Also, concerning these writings, the Spanish king played no role in favoring some authors over others. Except for the texts that the Irish Albert O'Farail translated and tried to print unsuccessfully between 1671 and 1693, the specific titles used by the Mission are not known (Bravo Lozano 2016). This is one of the most substantial differences between the Irish Mission and the work carried out by the Congregatio de Propaganda Fide in Ireland. The papal missionaries requested the recently printed Irish Grammar, the catechism Lucernam fedelium by Francis Molloy (Rome, 1676), the English Catechismus by Cardinal

${ }^{18}$ For the circulation of religious papers, see Watt (1991) and Gillespie (1995-1997). 
Howard and the Rituale Romanum published in 1614, amongst other doctrinal works. ${ }^{19}$

The circulation of these works was hampered by English laws (Bouza Álvarez 1995). The importation and sale of Catholic works were prohibited in England, and could only be printed clandestinely in local presses. Nevertheless, smuggling books from the Continent was cheaper than printing them surreptitiously on the island. The books were distributed by underground networks, where ecclesiastics sometimes acted as brokers of continental books (Allison and Rogers 1989). For father Juan and his enormous cargo, the legal framework posed a far bigger problem than the obstacles raised by the custom officers in Bilbao. A Ithough the Dominican may have exaggerated the number of books, he did not mention the plan to divide the books into smaller and more discreet boxes. A consignment of 200,000 books transported in one shipment would hardly have gone unnoticed by the British authorities, who would have seized and burned them, frustrating the whole project (Walsham 2000, 87). ${ }^{20}$

Sometime later, in 1681, two Irish priests arriving from Flanders, one of the main sources of Catholic books, were intercepted by the Plymouth port authorities. The inventory of goods carried out for the inquiry listed a series of books written in Spanish and Latin, manuscripts, letters to different addressees in Ireland and communion services. Thomist philosophical works, Patristic texts, commentaries on the Holy Scriptures by the Portuguese Carmelite João da Silveira, writings of logic, father Suarez's Metaphysics, the works of Saint John of the Cross and the Gaelic catechism of Theobald Stapleton were also part of this cargo. Alongside these volumes there were some books of sermons and prayers for different feasts, such as the panegyrics of Diego de Malo de Andueza, A suntos

${ }^{19}$ ASPF, Acta, vol. 57, ff. 62v-63r, 19. Petition of Nicholas Bodkin, OFM. Rome, 21 A pril, 1687; and ASPF, Scritture Originali riferiti nelle Congregazioni Generali, vol. 497, ff. 272r and 264r. Resolutions of the Congregation of Propaganda Fide addressed to Nicholas Bodkin and father Benedetto Sall. Rome, 21 A pril, 1687. Benignus Millett has identified petitions to the Congregation of Propaganda Fide concerning books published by different Irish members of the Franciscan Order. A mong these, the three works cited in the text were the most popular (2002-2003, 63-75).

${ }^{20}$ Despite many of the continental books being destroyed or lost during the successive wars, many are kept in the library of Trinity College Dublin (Pérez Tostado 2008, 30). 
predicables of the Benedict Diego Niseno, manuals for confessors like the one by the Franciscan Enrique de Villalobos, and some AngloLatin dictionaries. ${ }^{21}$

It is clear that the purpose of these priests was confessional. They had tried to smuggle the latest Catholic literary novelties from the Continent and the reeditions of certain works with which to assist their sermons and other pastoral tasks. The confiscation prevented these books from reaching their destination, but the political and religious thinking behind them continued unabated. The presence of second editions and later works on theology, morals and dialectics (published between 1660 and 1681), which had been written by the most up-to-date authorities from different religious orders, demonstrates that the missionary work in the British Isles was understood to be a global task. In fact, the cargo included texts that had been already disseminated in Madrid; these texts, imported from Flanders, attempted to reproduce the religious discourse of the royal court, taking some works from the "interior missions" as reference. ${ }^{22}$ These writings also conveyed a political message, by stressing the beneficial effects of Spanish sponsorship of the Irish.

The traffic of Catholic books and liturgical ornaments via the North Sea was constant at the end of the seventeenth century. It involved not only works printed by presses at St. Omer and other European locations, but also all kinds of devotional objects which were loaded onto ships on the Continent and destined for Ireland, England and Scotland. ${ }^{23}$ Mixed among other merchandise, just as the

${ }^{21}$ TNA: PRO, State Papers 29/417, ff. 394rv. List of books of two Irish priests. Plymouth, s. d., 1681.

${ }^{22}$ For instance Instrucciones predicables y morales no comunes, que deben saber los padres predicadores y confesores principiantes en especial los missioneros apostólicos (Seville, 1673) by the Franciscan José Gavarri and Casos raros de la confesión con reglas y modo fácil para hacer una buena confesión general o particular (Valencia, 1656) by Jerónimo López, were of great importance to the global missionary, although it must be noted that the praxies developed in the British Isles were different to Iberian practices (Palomo del Barrio 2007, 254-55).

${ }^{23}$ The press of St Omer's college was established and sponsored by Philip III in 1617 at the request of the Jesuit Joseph Creswell, superintendent of the seminaries and residences of the Englishmen in Castile and Portugal. The press secretly provided the English Mission with a great number of books, the significance of which has been analyzed in Bouza Álvarez (2002, 106-107). For the circulation of confessional works in Ireland, see Canny (1982). On the cultural influence of books in the relations between both crowns, see Creen (1985). 
missionaries were mixed among the sailors, these objects were smuggled into the dominions of the Stuarts for doctrinal purposes. This was nothing new: a few decades earlier, in 1621, Philip III had ordered his ambassador in Brussels, the Marquis of Bedmar, to hand six holy chalices and six chasubles of damask to father Nicolás de San Patricio, the Irish provincial of Saint Agustin, to celebrate Mass in his fatherland. However, owing to the personal circumstances of the priest and the difficulties involved in the transaction, the items were eventually handed over by the royal jeweler in Madrid. ${ }^{24}$ The ornaments were distributed among the Irish communities and served their purpose over the following 22 years. When they were worn out, and "there were no replacements, nor the possibility to make them," another Augustine father, Maurice Conald, asked Philip IV to:

renew these notable blazons of piety and devotion, giving six more in their place, decorating them with his name and coat of arms, like in the previous batch, so that everyone who said Mass in the kingdom of Ireland with them on, and those who heard them prayed to God for the prosperous success of Your Majesty and his dominions. ${ }^{25}$

Given the devout character of the petition and that these items could bring to the Mission, the king decided to send ten chalices, ten missals and other ornaments from the Low Countries. The Dutch route was the cheapest and the items could be delivered "more securely and promptly." 26 This is not an unimportant detail, as sometimes these deliveries were intercepted. In 1683, the London harbor authorities confiscated a suspicious cargo "loaded on a vessel from Flanders." A mongst other goods, the shipment contained three (non-inventoried) boxes of Catholic books; the customs report, however, specifies that the boxes contained "several crucifixes, breads and pictures."27 There are no more references to this

\footnotetext{
${ }^{24}$ AGS, Estado, leg. 2751. Consult of the Council of State. Madrid, 21 January, 1621.

${ }^{25}$ A GS, Estado, leg. 2803. Consult of the Council of State. Madrid, 23 January, 1640.

${ }^{26}$ As the councilors emphasized in their consultation, it was better to send the chalices from Spain or Flanders "for the risk that exists to make them there and the secret that it is necessary for it, not being so this as the ornaments because they are able to make them without more noise than the puntadas." AGS, Estado, leg. 2803. Consult of the Council of State. Madrid, 25 A ugust, 1640.

${ }^{27}$ TNA: PRO, State Papers 29/423, f. 198. Information on the confiscation. Whitehall, 16 A pril, 1683. In 1617, other shipmen that came from Spain were seized in Cork.
} 
consignment, except that it was seized, and thus it could well have been used to decorate a private chapel. Beyond their practical function, all of these resources and visual aids were aimed to cause a sensation among the recipients. Images were used to indoctrinate Catholic principles by triggering synesthetic reactions. Missionaries were encouraged to support their sermons with all kind of religious representations, including literary and non-literary filigree work (Gillespie 2005, 151).

Three years later, the English Secretary of State, the Count of Sunderland, received a list of books and other items from the Mayor of Lincoln, which was one of the main Catholic cities in the kingdom. During a routine search of the property of John Tarleton, officials found different manuals and the work Key of Paradise, bound in fillet and vellum, the catechism of Henry Turberville and that of the Cardinal Roberto Belarmino, books of prayers to the Virgin Mary and Saint Bridget, missals and other theological works such as Entertainments for Lent, Remonstrances, A bstracts, Following of Christ or Why are you a Catholic? Consisting of 158 volumes in total, this shipment had entered Lincoln without a problem. The accession of the Catholic James II to the throne removed the obstacles that had hitherto barred the entrance of Catholic books. In fact, "His Majesty's pleasure is that the Mayor of Lincoln do forthwith give order for restoring the above-mentioned books and papers to $\mathrm{Mr}$ John Tarleton." 28

The evidence, both from Ireland and England, indicates that a considerable number of books reached the British Isles from the Continent during the 1680s. Despite the fact that orality continued being the predominant means of indoctrination in the largely illiterate Ireland, these books provided effective support for the sermons delivered by the missionaries sent from Spain. As such, the books gave the Irish Mission an extra or auxiliary tool with which to disseminate the latest theological ideas and thus have a real impact. By means of these writings, objects and images, and the dissemination work carried out by the faithful, a widely scattered

According to the customer office's account, it had several religious images together with printed books, described in detail (Grosart 1887, 116-17).

${ }^{28}$ List of books and other things for John Tarleton. Whitehall, 13 A pril, 1686 (Timings 1964, 100). 
public could be reached, the religious message propagated and the definition of a spiritual model with which to shape the public conscience achieved (Gillespie 2005, 146-47).

The cargos compiled by father Juan de Santo Domingo in Bilbao (the safe delivery of which is unconfirmed), the purchase of books with the viaticum, as well as the lists of volumes in the customs record, highlight the active circulation of books towards the archipelago. This movement acted as a beacon for people to regularly send Catholic writings between Spain and Flanders in support of the missionary exercise. Writing and preaching were united behind a form of apostolic action that was particularly effective in that region. Jerónimo López's definition of “deaf missions" in his Casos raros de confesión, is applicable here, where the books turn into silent and discreet agents of the Spanish monarchy (Bouza Álvarez 2008).

\section{References}

Alcalá-Zamora y Queipo de Llano, José. 1975. España, Flandes y el Mar del Norte (1618-1639). La última ofensiva europea de los Austrias madrileños. Barcelona: Planeta.

Allison, A. F. and D. M. Rogers. 1989. The Contemporary Printed Literature of the English Counter-Reformation between 1558-1640. Aldershot: Scholar Press. 2 vols.

Bouza Álvarez, Fernando. 1995. "Contrarreforma y tipografía. ¿Nada más que rosarios en sus manos?" Cuadernos de H istoria M oderna 16: 73-88.

- - . 2002. "Una imprenta inglesa en el Madrid Barroco." Revista de O ccidente 257: 89-109.

- - - 2006. "Leer para creer. Religión y cultura del libro en la Edad Moderna." In Historia del Cristianismo. El mundo modern, Vol. III, Coordinated by Antonio Luis Cortés Peña, 637-79. Madrid: TrottaUniversidad de Granada.

- - . 2008. "Público pastoral: De la prédica a la imprenta. Da golosina y otras industrias de misionalización." In Papeles y opinión. Políticas de publicación en el Siglo de Oro, edited by Fernando Bouza Álvarez, 45-65. Madrid: Consejo Superior del nvestigaciones Científicas.

Bravo Lozano, Cristina. 2013. “Ex privilegio apostólico. La génesis de la Misión de Irlanda: Roma-Madrid, 1609-1624." In En tierra de confluencias. Italia y la M onarquía de España, siglos XV I-X V III, edited by Cristina Bravo Lozano and Roberto Quirós Rosado, 201-12. Valencia: Albatros Ediciones. 
- - . 2016. “'Se le dé papel, prensa y letras'. Albert O'Farail y el libro misionero The life of the Virgin M arie (1671-1693)." Cuadernos de $\mathrm{H}$ istoria M oderna 41: 51-70.

-_- (forthcoming). Spain and the Irish M ission, 1609-1707. London-New York: Routledge.

Canny, Nicholas. 1982. "The formation of the Irish mind: Religion, Politics and Gaelic Irish Literature, 1580-1750." Past \& Present 95: 91-116.

- - . 2001. M aking Ireland British, 1580-1650. Oxford \& New York: Oxford University Press.

Cano-Echevarría, Berta and A na Sáez-Hidalgo, eds. 2009. The Fruits of Exile: Emblems and Pamphlets from the English College of Valladolid. London \& Valladolid: Maggs Bros. and The Royal English College.

Creen, Ann Patricia. 1985. English Catholics as a Factor in Anglo-Spanish Relations, 1605-1625. Ann Arbor: The University of Michigan.

Cunningham, Bernadette. 2014. "Catholic Intellectual Culture in Early Modern Ireland." In Christianities in Early M odern Celtic World, edited by Tadhg Ó Hannracháin and Robert Armstrong, 151-62. New York: Palgrave-Macmillan.

Fenning, Hugh. 2009. "Students of the Irish college at Salamanca, 15921638." A rchivum Hibernicum 62: 7-36.

García Fernández, Ernesto, ed. 2005. Bilbao, Vitoria y San Sebastián: espacios para mercaderes, clérigos y gobernantes en el M edievo y la M odernidad. Bilbao: Universidad del País Vasco.

García Hernán, Enrique. 2006. "El Colegio de San Patricio de los Irlandeses de Madrid (1621-1937)." M adrid. Revista de arte, geografía e historia 8: 21949.

-_-. 2012. "The Irish College at Valencia (1623-1680): Historical Consequences." In Redes de nación y espacios de poder. La comunidad irlandesa en España y la A mérica española, 1600-1825, edited by Óscar Recio Morales, 93-102. Valencia: Albatros Ediciones-M inisterio de Defensa.

Gelabert, Juan E. 2001. Castilla convulsa, 1631-1652. Madrid: Marcial Pons.

Gillespie, Raymond. 1995-1997. "The Circulation of Print in Seventeenth Century Ireland." Studia Hibernica 29: 31-58.

- - . 1996. "The Book Trade in Southern Ireland, 1590-1640." In Books beyond the Pale. Aspects of the Provincial Book Trade in Ireland before 1850, edited by Gerard Long, 1-17. Dublin: Rare Books Group of the Library Association of Ireland.

- - - 1997. Devoted people. Belief and religion in Early Modern Ireland. Manchester: Manchester University Press. 
- - - 2005. R eading Ireland. Print, reading and social exchange in Early M odern Ireland. Manchester: Manchester University Press.

- - - 2006. "Print Culture, 1550-1700." In The Oxford History of the Irish Books. Volume III. Edited by Raymond Gillespie and Andrew Hadfield, 17-33. Oxford: Oxford University Press.

Grosart, Alexander B., ed. 1887. The Lismore Papers (second series). Vol. II. London: Chiswick Press.

Jennings, Brendan. 1959. "Ecclesiastical Appointments in Ireland, Aug. 1643-Dec. 1649." Collectanea H ibernica 2: 18-65.

Lenihan, Pádraig. 1999. Confederate Ireland, 1642-1649: A Constitutional and Political A nalysis. Dublin: Four Courts Press.

- - - 2001. Confederate Catholics at War, 1641-49. Cork: Cork University Press.

Maillard Álvarez, Natalia, ed. 2014. Books in the Catholic World during the Early M odern Period. Leiden: Brill.

Millett, Benignus. 2002-2003. "Irish Franciscans Ask Propaganda to Give Them Books for Their Pastoral Ministry in Ireland, 1689-1696." Collectanea Hibernica 44/ 45: 63-75.

Ohlmeyer, Jane H., ed. 1995. Ireland from Independence to O ccupation, 16411660. Cambridge: Cambridge University Press.

O'Connell, Patricia. 1977. The Irish College at Alcalá de Henares 1649-1785. Dublin: Four Courts Press

- - 2001. The Irish College at Lisbon, 1580-1834. Dublin: Four Courts Press.

_-_ 2007. The Irish College at Santiago de Compostela. Dublin: Four Courts Press.

Ó Hannracháin, Tadhg. 2015. Catholic Europe, 1592-1648. Centre and Peripheries. Oxford: Oxford University Press.

Ó Siochrú, Michael. 2005. "Catholic Confederates and the constitutional relationship between Ireland and England, 1641-1649." In British Interventions in Early M odern Ireland, edited by Ciaran Brady and Jane $\mathrm{H}$. Ohlmeyer, 207-29. Cambridge: Cambridge University Press.

Ó Siochrú, Michael and Jane Ohlmeyer, eds. 2013. Ireland: 1641. Contexts and Reactions. Manchester: Manchester University Press.

Palomo del Barrio, Federico. 2007. “Limosnas impresas. Escritos e imágenes en las prácticas misioneras de interior en la península Ibérica (siglos XVI-XVIII)." M anuscrits 25: 239-65.

_-_. 2011. "Misioneros, libros y cultura escrita en Portugal y España durante el siglo XVII." In M issions d'évangélisation et circulation des savoirs 
(XVI ${ }^{\mathrm{e}}-\mathrm{XVIII}{ }^{\mathrm{e}}$ siècle), edited by Charlote de Castelnau-L'Estoile, Marie Lucie Copete Aliocha Maldavsky and Ines G. Županov, 131-50. Madrid: Casa de Velázquez.

Pérez Tostado, Igor. 2008. I rish Influence at the Court of Spain in the Seventeenth Century. Dublin: Four Courts Press.

Recio Morales, Óscar. 2004. Irlanda en Alcalá: la comunidad irlandesa en la Universidad de Alcalá y su proyección europea, 1579-1785. Alcalá de Henares: Fundación Colegio del Rey.

Ryan, Salvador. 2011. "'Reaping a Rich Harvest of Humanity': Images of Redemption in Irish Bardic Religious Poetry." In H aving Life in H is N ame: Living, Thinking and Communicating the Christian Life of Faith, edited by Brendan Leahy and Séamus O'Connell, 239-52. Dublin: Veritas Publications.

- _ . 2013. "“Once I Heard a Story... from Scripture Does It Come': Biblical Allusions in Irish Bardic Religious Poetry." In Princes, Prelates and $P$ oets in $M$ edieval Ireland: Essays in $\mathrm{H}$ onour of Katharine Simms, edited by Seán Duffy, 524-37. Dublin: Four Courts Press.

-_- 2015. "'Scarce Anyone Survives a Heart Wound': The Wounded Christ in Irish Bardic Religious Poetry." In 'H is Brest Tobrosten': W ounds and W ound Repair in M edieval Culture, edited by Larissa Tracy and Kelly deVries, 291-312. Leiden: Brill.

Timings, E. K., ed. 1964. Calendar of State Papers. Domestic, James II. Vol. 2. London: Her Majesty's Stationery Office.

Walsham, Alessandra. 2000. “'Domme preachers'? Post-Reformation English Catholicism and the culture of print." Past \& Present 168: 72-123.

Watt, Tessa. 1991. Cheap Print and Popular Piety, 1550-1640. Cambridge: Cambridge University Press.

\footnotetext{
H ow to cite this note:

Bravo Lozano, Cristina. "Book culture in the Irish Mission: The case of father Juan de Santo Domingo (1636-1644)." SEDERI 27 (2017): 195-211.

A uthor's contact: cbraloz@upo.es

Postal address: Universidad Pablo de Olavide - Ctra. Utrera, km. 1 - 41013 Seville, Spain
}

Submission: 01/ 04/ 2017

A cceptance: 20/ 6/ 2017 


\title{
N elly or Ellen? Revamping the first English actresses in contemporary popular culture
}

\author{
Laura Martínez-García \\ U niversidad de O viedo, Spain
}

\begin{abstract}
The first British actresses have been the focus of extensive scholarly study, transposing the boundaries of academic life and irrupting in popular culture and becoming a part of the public imagination and folklore. This paper studies the perception we have inherited of "Pretty, Witty Nell," probably the best-known actress of the Restoration, through the analysis of two novels-Priya Parmar's Exit the Actress and Gillian Bagwell's The Darling Strumpet-that reconstruct Gwyn's life turning the "Protestant Whore" into a learned lady and a devoted mother. This revamping of her figure not only entails the erasure of the subversive potential of actresses' break with the public-masculine/ private-feminine dichotomy, but it also works as an attempt at neutralizing the threat that these "public" women pose to the gender roles that became normative in the seventeenth century and that are still seen as such nowadays.
\end{abstract}

KEYWORDS: Restoration; actress; identity; sexuality; fiction; Foucault; popular culture.

\section{¿N elly o Ellen? Reescrituras de las primeras actrices inglesas en la cultura popular contemporánea}

RESUMEN: Las primeras actrices británicas han sido objeto de innumerables estudios, Ilegando a traspasar las barreras del mundo académico e irrumpir en la cultura popular, hasta convertirse en parte del imaginario y folklore popular. Este artículo estudia la percepción que hemos heredado de la que probablemente sea la actriz más conocida de la Restauración, Nell Gwyn, mediante el análisis de dos novelas-Exit the Actress, de Priya Parmar, y The Darling Strumpet de Gillian Bagwell-en las que se reconstruye su vida para hacer de la "prostituta protestante" una dama respetable y madre amantísima. Esta reconstrucción

\section{Nelly ou Ellen? Reconfigurando as primeiras atrizes inglesas na cultura popular contemporânea*}

RESUMO: As primeiras atrizes britânicas têm sido objeto de inúmeros estudos, transpondo as barreiras do mundo académico e irrompendo na cultura popular, passando a fazer parte do imaginário público e do folclore. Este artigo estuda a perceção que herdámos sobre Nell Gwyn, provavelmente a mais conhecida atriz da Restauração, por via da análise de dois romances-Exit the Actress, de Priya Parmar, e The Darling Strumpet, de Gillian Bagwell-que reconstroem a vida de Gwyn, tornando a "prostituta protestante" numa senhora cultivada e numa mãe dedicada. Esta reconfiguração da figura de Nell Gwyn não só apaga o

*Translation into Portuguese by Miguel Ramalhete. 
de la actriz no sólo supone una eliminación del potencial subversivo de su ruptura con la división público-masculino/ privado-femenino, sino que es además un intento de neutralizar la amenaza que lo público de sus personas suponen para los roles de género instaurados en el siglo XVII y que aún perviven hoy en día.

PALABRAS CLAVE: Restauración; actriz; identidad; sexualidad; ficción; Foucault; cultura popular. potencial subversivo do corte das atrizes com a dicotomia masculino-público / feminino-privado, mas funciona também como uma tentativa de neutralizar a ameaça que estas mulheres "públicas" colocam aos papéis de género que se tornaram normativos no século XVII e que ainda são assim entendidos atualmente.

PALAVRAS-ChAVE: Restauração; atriz; identidade; sexualidade; ficção; Foucault; cultura popular.

In 2010, Jerome de Groot declared that "the historical novel [was] in robust health, critically, formally and economically" $(2009,1)$ as evidenced by the sales figures of the genre and the size of the section in any given bookshop; more interestingly, in his revised monograph Consuming History (2016) de Groot points towards the intersections of this genre with other categories which have resulted in the creation of fascinating hybrids like the literary subgenre of historical romance, of which Philippa Gregory has become the undisputable queen, thanks to her Tudor and Plantagenet series.

This paper analyses examples of these hybrids in the shape of two relatively recent historical romances that revamp the figure of the acclaimed Restoration actress, N ell Gwyn, Priya Parmar's Exit the A ctress (2011) and Gillian Bagwell's The Darling Strumpet (2011), to study how these historical romantic novels rewrite Gwyn's life, transforming her into a romantic heroine that fits normative and canonical gender roles.

Although it is true that Nell Gwyn is one of the best-known characters of the Restoration and that she has been hailed as the embodiment of the age, her life still remains a mystery and most of the anecdotes connected with her cannot be verified. Take, for example, one of the classic "Gwyn" moments,

The story [...] is a known fact; as is also that of her being insulted in her coach at Oxford, by the mob, who mistook her for the dutchess of Portsmouth. Upon which she looked out of the window, and said, with her usual good humour, Pray, good people, be civil: I am the protestant whore. This laconic speech drew upon her the blessings of the populace, who suffered her to proceed without further molestation. (Granger 2010, 429) 
The veracity of this "known fact" has been put into question very recently by historians and scholars (Conway 2006, 209) who have argued that "Restoration history is written primarily through the circulation of well-known anecdotes" rather than historical data (Pullen 2005, 25), a fact that contributed to the emergence of a "celebrity" culture which heavily relied on gossip and the mystery surrounding the new divas of Drury Lane: actresses.

Taking into account the lack of verifiable historical data on Gwyn's life and understanding that "the spaces scholars have no idea about-the gaps between verifiable fact-are the territory for the writer of fictional history" (de Groot 2016, 264), Gwyn's whole "life" becomes the writer's territory, susceptible of being rewritten and reimagined in any way the author chooses. This may justify the variety of Nells that have cropped up through history: in the last hundred years, Gwyn has been the face of orange marmalade, a tourist attraction in Drury Lane, the runner of a brothel in Kate Baker's steampunk series The Women of N ell Gwynne (2009) and a shrewd manipulator in Richard Eyre's Stage Beauty (2005). Furthermore, accounts of her life are not just suspiciously divergent from each other, but sometimes contradictory: while GrumleyGrennan (2010) and Hopkins (2000) insist on the mystery surrounding her childhood and Cunningham skates over the issue (2009), Ditmore's entry for her in the Encyclopedia of Prostitution and Sex W ork $(2006,192)$ openly paints her as a child-prostitute.

These myriad representations of $\mathrm{Nell}$, as well as the two novels that occupy this study, have one common feature: they take Gwyn's sexuality as their defining characteristic, resulting in a reimagining of Nell as either a whore or an angel, continuing with the practice explained by Straub,

the "ambiguity" of the actress-was she or wasn't she a whore?is often the focus of representations that seek to "resolve" the problem through an array of strategies dependent upon the actresses' personal biography, her recuperability into existent class structures, and the historical moment in the changing field of eighteenth-century sexual ideology. $(1992,16)$

This study argues that the subversive female performer of the Restoration is domesticated and stripped of her power, not through seventeenth-century slut-shaming, but rather through her "redemption" as the prostitute with a heart of gold (Cunningham 
2009 , 2) or a reimagining as a learned, dignified lady. Although Wallace argues that the historical novel has been seen as a tool which "allowed them [women writers] to invent or re-imagine [...] the unrecorded lives of marginalized and subordinated people, especially women" $(2004,2)$, in the case of these two novels, the lack of verifiable data is used to strip her off the subversive potential associated with early female performers by shifting the focus to the Cinderella quality of her Royal affair, thus contributing to the fashioning of Gwyn as the heroine of a romantic novel and to the perpetuation of the "darling strumpet" image.

The Restoration, an "age of the actor rather than the play" (N ussbaum 2005, 149), is the moment in history when the "celebrity" movement we now take for granted was born in England thanks to the incorporation of women to the theatrical world; the 1660s were the anteroom of the epistemological revolution of the eighteenth century, when, as Michel Foucault argued, the medieval feudal system was replaced with an early-modern deployment that classified individuals in binary opposites (sane/ insane, healthy/ sick, man/ woman) derived from scientific discovery and research (1990, 83). It was under the rule of the Merry Monarch that the first glimpses of a new regime in which "biology [...] assures marital order" (Laqueur 1990, 193) could be perceived in Britain and "the long period between the reign of King Charles I and the death of Queen Anne, is a transitional moment for the British Nation" (Martínez-Garcia 2014, 400), an in-betweenness or state of constant flux, straddling two opposing forces: a medieval conception of the world (or deployment of alliance) and an Enlightened scientific discourse which based gender order on the biological differences between the sexes and their ability to inhabit either the public or private spheres of life (Fletcher 1999) or the deployment of sexuality (Foucault 1990, 106).

More importantly, this "construction of femininity within the private sphere, coincides with the licensed appearance of the actress on the British public stage" (Bush-Bailey in Stokes 2007, 16) an event which sparked serious social conflict. Actresses, as women who were supposed to stay in the house but did not, violated the gender order and became "curiosities in the same aberrant category as the exotics [...] exhibited in public places for commercial return" (Nussbaum 2005, 149). As Gwyn's anecdote proves, sexuality became a central 
feature in the characterization of actresses, who were "caught in crosscurrents that defined their sexuality as public by profession and private by gender" (Straub 1992, 90), a dichotomy that was both the cause for their success and their downfall: on the "positive" side, the promised availability of their bodies became successful publicity for theaters and companies which soon started selling "public intimacy" a kind of "public performance produced expressly for the purpose of stimulating theatrical consumption [...] [an] illusion [which] makes possible the creation of desire, familiarity and identification" (Nussbaum 2005, 149).

Still, actresses' public exposure of their private bodies threatened to dilute the distinction public/ private, male/ female which formed the basis of social order, and, consequently, became symbols of transgression as they not only abandoned the private sphere, but also robbed men of their role as breadwinners: they were the ultimate gender-benders, who openly and publicly questioned gender roles and the ordering of society. Hence, the system attempted to neutralize the threat by drawing "parallels with prostitution, a link that has endured for generations in a patriarchal society employing the binaries of private/ public, virgin/ whore as its constructs of femininity" (Bush-Bailey 2009, 12-13) and which is reflected in the survival of Gwyn's carriage anecdote. In fact, and in an attempt at neutralizing the possible threat that the publicness of the actress may pose, "the lower-class background of the most promiscuous actresses is stressed, even exaggerated" (Straub 1992, 90) through the circulation of stories, like that of the carriage, that focus "on their sexual relationships" thus creating "a discursive link between first generation and prostitution" (Pullen 2005, 26).

No actress embodies the double dimension of Restoration fame like Gwyn: none other is more familiar than the orange seller turned Royal lover whose name has become a synonym for the Restoration at large. She was, without a doubt, the first "It girl" (Roach 2007, 63), pioneer of modern celebrity, of "the star-system that is very much part of our culture today" (Payne Fisk and Canfield 1995, 16). And although her status as a whore was a central part of her identity during her lifetime and in her after-life as a cultural icon, the potential for "recuperability" that lies in Gwyn's Cinderella-like story makes for fertile ground upon which to build the 
transformation of the subversive gender-bender into a romantic heroine that fits into the canonical gender roles still at work today.

This practice started when Gwyn's defenders claimed she had risen to the top in spite of her obscure past, in an attempt at making us root for the heroine. Wilson is quite clear in his account, when he declares that "one of the greatest triumphs of Nell's life was her ability to survive infancy and childhood" (1952, 11). Dryden, her contemporary, writes an epilogue especially for her in what would be her last role onstage and has her declare she has "liv'd a Slatern| Yet dy'd a Princess" (in Zwicker 2004, 139), a reminder not just of her uncertain and debauched origins, but a reference to her status as Royal Concubine that immediately activates connections to her longstanding affair with King Charles and reaffirms her as the first "People's Princess," thus making her social climbing a success story and turning the "whore" of the pamphlets into a member of the Royal family.

These rumors and stories about Gwyn's family and connections, turned into "fact" and "history" through repetition and reiteration (Pullen 2005, 27), are the basis for Bagwell's novel The Darling Strumpet, which presents us with a precocious ten-year-old girl and her first incursion into the world of prostitution,

Nell's stomach heaved with nervous excitement, but remembering Barbara Palmer's easy confidence, she managed an inviting smile as she looked up at him. She thought of what Deb and Molly had said-was it only this morning?-about the riches to be made this night. $(2011,18)$

The girl will sell her virginity to a teenager who cheats her of her money, passes her on to his friends and leaves her to fend for herself once the deed is done (Bagwell 2011, 8-20). The portrait Bagwell paints of Nell seems to confirm the views of seventeenth-century moralists who claimed that, from an early age, the lower classes showed a tendency to depravity and a precocious sexual drive that, in the case of Nell, soon drives her to a whorehouse, where she will be used and abused by a multitude of men. Bagwell includes detailed descriptions of Nell's sexual activities at the whorehouse and the minutiae of the depravation of the men who demand Nell's services, not only emphasizes the relationship between the lower classes and unbridled sexual desire which seemed apparent during the Restoration (Straub 1992, 90-91), but also offers a glimpse into 
Nell's future with the appearance of a young man who will whisk her away from the brothel to a comfortable life Gwyn abhors: "before long, she found the sameness of her days grew tedious" (Bagwell 2011, 68).

Gwyn's lack of interest in domesticity justifies her entrance to "the playhouse - anything might happen there" (Bagwell 2011, 88); soon Nell becomes the most celebrated orange-seller with desirability and fame increasing at the same pace. Nell is soon tempted by the luxurious life the Court Wits offer her: passing from the hands of Rochester (her instructor in all matters sexual) to those of Charles Sackville and his friend, Nell will be transferred from one bed to the other, an object intended for the fulfilment of male pleasure, reveling in the supposed admiration of these men and in the luxury they provide her with. It is not until the affair is over, that Bagwell, in an intrusion of twenty-first-century morals upon seventeenth-century society, has N ell reflect on these men's abuse of her person and body (Bagwell 2011, 165-66).

This reification of the actress's body was commonplace during the Restoration when all performers were seen as trade goods. In the case of actresses, this was even more so: once these women broke out from the relative safety of the home (as Nell does when she abandons Robbie's house), they came under public scrutiny and gossip, losing their right to privacy and becoming "public" women in the widest sense of the term. They moved from the private ownership of a father/ husband to become commodities any theatergoer could buy or rent provided he had the money to pay the fee (Nussbaum 2005, 149). Bagwell's equating of $\mathrm{Nell}$ and her body with property, or "the paradigm of the lower-class woman as commodity of the upper-class male contains the troublingly public sexuality of many actresses" (Straub 1992, 91) and ultimately serves as a way to limit her subversiveness. When Bagwell has Nell claim that "she felt dirty, and foolish to have thought that they regarded her as anything but a whore, bought and paid for" (2011, 168), she is continuing in the tradition of identifying actresses with their bodies and sexuality, a representation that 'does little to establish (their) actresses' respectability as a group" (Straub 1992, 92) specially if we take into account Nell's passive reaction to the leaking of her sexual adventures with the trio, a move that certainly limits, if not completely erases, the subversive power of her realization. 
In her novel Exit the Actress, Parmar confesses that while she "invented much of Nell's daily life" the historical facts that frame Gwyn's biography "are rooted in fact" $(2011,443)$ creating thus a narrative that concentrates "on the gaps between known factual history and that which is lived" (de Groot 2016, 263-64) and that seems to reject most of the inherited wisdom about Gwyn's life. She is now the daughter of a soldier fallen on hard times, educated and boasting a set of morals closer to eighteenth-century precepts which completely erase any possibility of her being the prostitute "history" has painted her to be. Young Nell's experience in the brothel is transferred to her sister Rose and in relation to Charles Hart, Nell's grandfather states "I know that you could not give your body without your affection" (Parmar 2011, 101). With this characterization, Parmar severs all connections with the innate depravity and the unscrupulous social climbing of the lower classes and creates a different woman, not Nell but Ellen, a sensible and respectable woman who is capable of showing all the qualities of a lady in spite of an unfortunate upbringing.

Although Parmar's protagonist allows the public to call her Nell, she refers to herself as Ellen, ${ }^{1}$ thus highlighting the distance between the real person and the public performance of "pretty, witty Nelly." By strengthening this difference between public and private, between "real" and "performed," Parmar tries to buttress her hypothesis that the inherited wisdom which paints Nell as goodnatured, rude and ignorant may be a façade to hide the "real" woman, an intelligent, sensitive and nurturing girl, ready for love, features that make Ellen a temptingly "recuperable" figure that fits snugly into the canon of femininity preached from the eighteenth century onwards.

In spite of taking opposite starting points to their reimagining of Gwyn (whore and lady), both Bagwell and Parmar use the second part of their novels to build a "romantic" fairy-tale story in which Ellen becomes Charles's spiritual companion, leaving the theater to devote her life to the Royal children as the role of the actress and "wife" are truly incompatible (Straub 1992, 94) in a society which saw the visibility of the actress and her public staging of her private

1 “They call me Nell. But I am Ellen, I think” (Parmar 2011, 135). 
sexuality as a loss of prescriptive femininity, linked to domesticity, motherhood and public invisibility.

In spite of the unmarriageability of actresses and despite the different approaches that Bagwell and Parmar take to Gwyn's entrance into the King's favor, both authors take great pains to portray the affair as that of a happily married couple: a comfortable relationship, which naturally moves from a passionate coupling to easy companionship and understanding with the passing of years. The domesticity of some of Gwyn's and Charles's exchanges is a feature that both novels have in common and one which seems to try and atone for the fact that both Nell and Charles were, in fact, unmarriageable: not only was he the King and her superior in class and rank, but he was al ready married and she was, as an actress and a concubine, twice a whore.

Parmar and Bagwell seem to try to create the illusion of marriage in the scenes where we can find the lovers together: Bagwell, who had shown Nell bored with domesticity in the first half of the book, offers now descriptions that emphasize the snugness and comfort of their exchanges, such as the opening lines of chapter seventeen: "The King's bedchamber was cosy, the blazing fire and dancing candlelight driving the shadows into the corners. Nell and Charles were propped against the pillows in the big bed" $(2011,218)$, thus creating a quotidian scene that many readers can identify with, an image which turns their illicit affair into something not just admissible and normative (from concubine to almost-wife), but completely justified and, to a certain extent, desirable.

Exit the A ctress also portrays Ellen as resisting domesticity when offered by the "wrong" man: Parmar's heroine rejects Harts's advances and offers arguing "I want truer love than what we shared" $(2011,212)$, an unlikely reflection for a Restoration woman, but one which appeals not just to the reconstruction of Gwyn as a romantic heroine, but to twenty-first-century's sensibilities and ideas on love. Parmar's novel, which seems to be deeply invested in the recreation of Gwyn as a respectable woman, gives us scenes in which not only do readers discover the fondness of both characters for each other, but which allow us into their private lives, to discover the similarities they bear to our own. While walking around the streets of Oxford, King Charles point out the architecture of the place to this eager pupil $(2011,270)$, while he talks fondly about his family, taking 
an interest in Ellen's background and friends (2011, 271-73); Parmar's portrayal of the relationship includes walks, confidences, tender words, a wealth of letters between the lovers full of endearments and pet names (2011, 291-92), passionate if quotidian quarrels (2011, 295-96), weekend getaways with friends (2011, 299) and what Ellen calls their "private time at the end of the public day" (2011, 303), pillow-talk intended to reinforce their closeness; thus, through these domestic tableaux Parmar turns this relationship into a mock-marriage, elevating Ellen from concubine to wife.

Furthermore, the descriptions of the easy intimacy, the pictures of domesticity and the many instances in which the two lovers console each other on their misfortunes, are all devised to give their relationship the appearance of what Stone calls a "companionate marriage" (1990, 325), the archetypal image of the ideal marriage that was gaining force in the seventeenth century and which has been seen as the embodiment of the normative gender roles that emerged then and which have survived well into our days: the woman stays at home, waiting for her husband's return so she can alleviate his troubles and keep him comfortable in his own home. Thus, Nell/ Ellen is domesticated, into abandoning theatrical life for a domestic one, a choice that turns her into a "wife," neutralizing the threat she posed as a public figure.

During the seventeenth and eighteenth centuries, normative femininity became linked to domesticity and nurture, two features seen as biologically inherent to females; thus, the system encouraged "women [...] to embrace motherhood as both a spiritual and practical calling" (Heller 2011, 19). All throughout history, defenders of Gwyn have highlighted these two features in their reconstruction of $\mathrm{Nell} /$ Ellen, emphasizing her role as mother and nurturing soul attending to the needs of her family, friends and of those less privileged, a strategy designed to accentuate her kindness in an attempt at clearing her name and separating her from the whore/ actress binary. A phra Behn, icon of proto-feminism, uses her dedication to The Feign'd Courtesans to emphasize that Nell's goodness made her renounce any titles (something the rest of Charles's mistresses had not done) in favor of her children, highlighting Gwyn's generous nature and disregard for social elevation, while portraying her as a loving mother to Charles's progeny: 
whom [her children] you have permitted to wear those glorious Titles which you yourself generously neglected, well knowing with the Noble Poet; 'tis far better to merit Titles than to wear them. $(1996,87)$

This praise of Gwyn reminds readers of Behn's own Angellica Bianca in The Rover, whose "self-construction as Petrarchan mistress charts the attempt of a woman excluded from the marital marketplace to turn her beauty into an alternative form of power" (Pacheco 1998, 323). Behn's praise elevates Gwyn as a selfless mother and unambitious lover, implying that N ell's happy acceptance of her roles as the Royal Concubine and whore/ actress are a public performance that, in actual fact, hides her true identity as a lady of quality (Rosenthal 1993, 18). Peter Cunningham, one of Gwyn's most celebrated biographers, opens his account of Gwyn's life arguing that she is a favorite of Britain because

with all her failings, she had a generous as well as a tender heart; that, when raised from poverty, she reserved her wealth for others rather than herself; and that the influence she possessed was often exercised for good objects, and never abused. (2009, 2)

Following in the footsteps of these two authors, Parmar presents us with an episode which reinforces this image of Ellen as a devoted mother: after abandoning Hart for Saville, Ellen learns she is pregnant with Hart's child and goes back to him. She then has a miscarriage after an accident and takes to her bed, desolate about the loss of her child; once she is deemed fit enough to return to the theater, she indignantly refuses, "Dr Bangs has proclaimed me healed. How can I be healed when I feel so unwhole? I am in such small pieces I cannot imagine how to fit them together again" (2011, 118). Miscarriages were seen common in the sixteenth century, to bore with discretion (Gelis 1996, 217) and a suspected punishment for Eve's disobedience (Anselment 1995, 52-53). Still, with the deployment of sexuality, attitudes to the loss of a child changed, with parents now publicly grieving the loss; thus, Nell's reaction to the news and the portrayal of her desolation add to her image as the ideal woman of the new social order, the nurturing mother, and bear witness not only to the shift in gender roles, but to the "changing parent-child relationship traced by Phillipe Aries and Lawrence Stone" (Anselment 1995, 55). 
Although Bagwell does not portray such an event, she does concentrate a great part of her book on Nell's close relationship with her children, including her insistence on nursing them herself, to the desolation she feels after her second son by Charles dies; Bagwell insists on the tenderness both Charles and Nell feel for their children, portraying them as "the emerging [...] new family type" (Stone 1990, 683) of the late seventeenth and early eighteenth centuries. In fact, the arrival of her first child works in the book to signal the change in the relationship between Charles and Nell, for the exciting life of parties and plays turns into the familiarity al ready discussed. Scenes of domesticity and companionship are as present in this second part of the book as the detailed descriptions of sexual encounters were in the first half and they are designed to change the reader's perception of N ell, from a loose and frivolous young girl, to a protective mother and "wife."

Bagwell's book devotes a great time and effort to the description of Nell's later years, and of her relationship with her less fortunate friends and with King Charles himself. Readers witness Nell's decision to abandon not just the theatrical world, but the public world of the Court as well, retiring to her house, happy to receive her friends, family and lover, to listen to their woes and to help them and offer solace whenever possible, turning Nell into the epitome of normative femininity and transforming the public woman into a domestic goddess.

To further emphasize this, Bagwell imagines a conversation between $\mathrm{Nell}$ and her confessor (the man who would actually officiate her funeral): here not only does the priest excuse Nell's questionable past, but she openly declares her desire to become Charles's wife, turning this former whore-actress into an honorable woman redeemed from sin by the purity of her love, her loyalty to the King and selflessness,

"Tell me," Dr Tenison asked, "would you have married the king had you been able?"

"Of course," Nell said.

"And were you true to him?"

“I was" ...

"[...] Your relations with him were grievous sin. But you have shown that you have a Christian heart, by many deeds in the time 
that I have known you. And I have no doubt that there were many more in your life before that. You have shown charity for the poor, the sick, those who could not of their own accord make their lives better or more comfortable. And I know that you have done it out of concern for them, admonishing me frequently that no one should know the source of their help." (2011, 310-11)

Thus, Bagwell's Nell undergoes a transformation from whore, to actress-whore, to Royal mistress and to devoted mother and wife, redeemed of her wild and questionable past by love and charity, two of the central characteristics that the new order of things believed women possessed innately. It seems that Bagwell's novel is a tale of redemption and $\sin$ in the fashion of eighteenth-century moral novels: the whore is transformed into a loving wife, thus buttressing the gender roles preached by the new system. Parmar's protagonist, a young woman who already possesses all the "innate" qualities of an honorable lady is elevated to the category of romantic heroine and her affair with the King comes as a reward for her staying true to her normative femininity instead of giving in to a life of lewdness: hers is a tale of good deeds rewarded.

This paper has shown that attitudes towards early actresses, towards the women who first broke the boundaries between the public/ private were, and continue to be, mixed. The seventeenth century saw the emergence of a society characterized by its insistence on the ordering of the universe and the organization of life in clearly differentiated binaries: actresses, with their blurring of the lines that had been so painstakingly drawn to separate public from private, male from female, normal form abnormal, were, and still are, a threat to the established gender order.

The general attitude towards these women who publicly performed their private selves alternated between fascination and revulsion, between acceptance and celebration, rejection and criticism. The two historical novels studied are revisionist in their attempt at painting Gwyn's character and bear witness to the struggle of reconstructing early-modern women and their lives. As the subject of historical romantic novels, Gwyn's biography is invoked or rewritten to create two different romantic heroines that will appeal to twenty-first-century audiences: whether it be to tell the tale of the good-hearted prostitute or the story of the middleclass prodigy fallen into hard times, Parmar and Bagwell offer tales 
of redemption through femininity, "true love," motherhood and charity.

Thus, in the hands of these authors, Gwyn loses all of her subversive powers, all of her significance as a symbol of transgression, as the epitome of the "gender-bender," moving from the "whore" side of the spectrum to join the ranks of subjects that do not question, but buttress the rigid and limiting gender roles imposed by the established gender order. This portrait of Gwyn, coupled with the fact that "any historical novel always has as much, or perhaps more, to say about the time in which it is written" (Wallace 2004, 4) rather than the time it is set in, leads me to conclude that these novels are an example of a sub-genre that "seems to sustain the dominant models of social ordering: family, heteronormative relationships and strictly defined gender roles" (de Groot 2009, 52).

\section{References}

Anselment, Raymond A. 1995. The R ealms of A pollo: Literature and $\mathrm{H}$ ealing in Seventeenth-Century England. N ewark: University of Delaware Press.

Bagwell, Gillian. 2011. The D arling Strumpet. London: Avon.

Baker, Kage, and J. K Potter. 2009. The Women of N ell Gwynne's. Burton, MI: Subterranean Press.

Behn, A phra. 1996. The Works of A phra Behn: The Plays 1678-1682. Edited by Janet Todd. London: W. Pickering.

Bush-Bailey, Gilli. 2009. Treading the Bawds: Actresses and Playwrights on the Late-Stuart Stage. Manchester: Manchester University Press.

Conway, Alison. 2006. “Known Fact or Urban Legend? Nell Gwynn's Oxford Pronouncement." Notes and Queries 53 (2): 209-10. doi:10.1093/ notesj/ gjl030.

Cunningham, Peter. 2009. The Story of N ell Gwyn - A nd the Sayings of Charles the Second. Kirkwood: Ballou Press.

Ditmore, Melissa Hope. 2006. Encyclopedia of Prostitution and Sex W ork. Santa Barbara: Greenwood Publishing Group.

Eyre, Richard. 2005. Stage Beauty. Lions Gate.

Fletcher, Anthony. 1999. Gender, Sex and Subordination in England, 1500-1800. New Haven: Yale University Press.

Foucault, Michel. 1990. The History of Sexuality, V olume I: An Introduction. London: Random House. 
Gelis, Jacques. 1996. H istory of Childbirth: Fertility, Pregnancy and Birth in Early M odern Europe. Cambridge: Polity.

Granger, James. 2010 [1774]. A Supplement, Consisting of Corrections and Large A dditions, to a Biographical $\mathrm{H}$ istory of England, and a List of Curious Portraits of Eminent Persons [... ] to the A uthor, James Granger. Volume 2 of 2. Gale ECCO, Print Editions.

Groot, Jerome de. 2009. The Historical Novel. The New Critical Idiom. London: Routledge.

_- - 2016. Consuming History: Historians and Heritage in Contemporary Popular Culture. London: Routledge.

Grumley-Grennan, Tony. 2010. Tales of English Eccentrics. Lulu.com (SelfPublished).

Heller, Jennifer. 2011. The M other's Legacy in Early M odern England. New edition. Farnham, Surrey; Burlington, VT: Routledge.

Hopkins, Graham. 2000. N ell G wynne. London: Robson Press.

Laqueur, Thomas Walter. 1990. M aking Sex: Body and Gender from the Greeks to Freud. Cambridge: Harvard University Press.

Martínez-Garcia, Laura. 2014. Seventeenth- and Eighteenth-Century English Comedies as a $\mathrm{N}$ ew Kind of Drama: A Foucauldian Interpretation of Family Relations, Sexuality, and Resistance as Psychological Power. Lewiston: Edwin Mellen Press Ltd.

Nussbaum, Felicity. 2005. "Actresses and the Economics of Celebrity, 17001800." In Theatre and Celebrity in Britain, 1660-2000, edited by Mary Luckhurst and Jane Moody, 148-68. N ew York: Palgrave Macmillan.

Pacheco, A nita. 1998. "Rape and the Female Subject in A phra Behn's The Rover." ELH 65 (2): 323-45. doi:10.1353/ elh.1998.0013.

Parmar, Priya. 2011. Exit the Actress. New York: Touchstone/ Simon \& Schuster.

Payne Fisk, Deborah, and John Canfield. 1995. Cultural Readings of Restoration and Eighteenth-Century English Theater. Athens \& London: University of Georgia Press.

Pullen, Kirsten. 2005. Actresses and Whores: On Stage and in Society. Cambridge: CambridgeUniversity Press.

Roach, Joseph R. 2007. It. Ann A rbor: The University of Michigan Press.

Rosenthal, Laura J. 1993. “'Counterfeit Scrubbado': Women Actors in The Restoration." The Eighteenth Century 34 (1): 3-22.

Stokes, John. 2007. The Cambridge Companion to the Actress. Cambridge: Cambridge University Press. 
Stone, Lawrence. 1990. The Family, Sex and M arriage in England, 1500-1800. London: Penguin.

Straub, Kristina. 1992. Sexual Suspects: Eighteenth-Century Players and Sexual Ideology. Princeton: Princeton University Press.

Wallace, D. 2004. The Woman's H istorical N ovel: British Women Writers, 19002000. Basingstoke: Palgrave Macmillan.

Wilson, John Harold. 1952. N ell Gwyn, Royal M istress. New York: Pellegrini \& Cudahy.

Zwicker, Steven N., ed. 2004. The Cambridge Companion to John Dryden. Cambridge, UK; N ew York: Cambridge University Press.

H ow to cite this note:

Martínez-García, Laura. "Nelly or Ellen? Revamping the first English actresses in contemporary popular culture." SED ERI 27 (2017): 213-28.

A uthor's contact: martinezlaura@uniovi.es

Postal address: Universidad de Oviedo - Dpto. Filología Inglesa, Francesa y Alemana Amparo Pedregal s/ $n$ - 33011 Oviedo (Asturias), Spain

Submission: 25/ 04/ $2016 \quad$ A cceptance: 04/ 07/ 2016 


\title{
Dominic Cooke, dir. 2016. The Hollow Crown: The Wars of the Roses. N eal Street Productions, N BC Universal, WN ET. DVD. (BBC, 2016)
}

\author{
Víctor Huertas Martín \\ U niversidad N acional de Educación a D istancia \\ U niversidad A utónoma de M adrid, Spain
}

The BBC has celebrated Shakespeare's 400th A nniversary with the heritage epic series The Hollow Crown: The W ars of the Roses, a threeepisode sequel to the first series produced by Sam Mendes in 2012. The first series consisted of four film versions of Richard II, H enry IV Part 1, H enry IV Part 2, and $H$ enry V. Therefore, the second comprises the three parts of H enry VI and dedicates a final episode to Richard III. Although, arguably, Shakespeare's original Henriads were not staged according to the chronological order of the reigns, following suit with its 1960s serial precedent An A ge of Kings, the BBC thought it fitter to follow the real historical line of kings from Richard II to Henry VII's accession to the English throne. Theoretically, this order might reinforce E. M. W. Tillyard's propositions on the Tudor Myth (1974). Consequently, the whole series could be taken as the retelling of the English decline after Richard II's deposition and the subsequent redemption of England with the advent of the Tudor monarchy. Nevertheless, if the Shakespearean explosion of the 2012 London Olympics gave way to a conclusion of the first series with Tom Hiddleston's rising as Prince Hal and his burial as King Henry $\mathrm{V}$, consciously or not the second series was made to coincide with the extremely controversial Brexit referendum. At a time in which the British nation faces one of its greatest historical crises, The Wars of the Roses appears as a more than appropriate topic because of its numerous resonances with the Shakespearean texts. Certainly, it is not an accident that An A ge of Kings and John Barton and Peter Hall's The $W$ ars of the R oses have been reedited and re-released on DVD in 2013 and 2016 respectively. ${ }^{1}$ Likewise, the creative team and some reviewers have alluded to the similarities of the series with the HBO

\footnotetext{
${ }^{1}$ Actually, the DVD reedition of Barton and Hall's The W ars of the R oses were released two days after the results of the Brexit referendum were published on 24June 2016.
} 
Game of Thrones series. ${ }^{2}$ This saga has become a television classic that consciously proclaims its Shakespearean origins and its inspiration from the two Henriads. ${ }^{3}$ M ore specifically, the character of Richard III has also been highly celebrated through the discovery of his remains at Grey Friars Church, Leicester, and through specific events like Kevin Spacey's Bridge Project tour and Rupert Goold's recent production at the Almeida Theatre. ${ }^{4}$ Therefore, the series appears surrounded by what seems to be a flurry of interest in the decline of the Plantagenets and the rise of the Tudors.

Although this second series displays elements of continuity with the first one-i.e. Anton Lesser plays Exeter in both series and Westminster Palace is used as a location in both of them-in many ways it departs from the 2012 structure. Whereas the first four episodes were treated as self-conclusive films by three different directors-Rupert Goold, Richard Eyre and Thea Sharrock-in this production, Dominic Cooke is the director for all three films and, in association with Ben Power, is responsible for the cutting and editing of the four Shakespeare plays. This editing has resulted in a single filmic narrative arch out of four plays that could be taken as individual stories. Two main strategies were followed to condense these four plays into a period of only six hours. Firstly, Power and Cooke excised everything which did not strictly apply to the feud between the Houses of Lancaster and York. All in all, we attend the accession of Henry VI as a nine-month-old baby and we end up with the overthrowing of Richard III (Benedict Cumberbatch). This means that Jack Cade's revolt has been entirely expunged and the subplots related to Jean La Pucelle, John Talbot and the French Dauphin have been heavily cut or eliminated too. Nevertheless, although the text is abridged, a constant pattern in the three episodes is that the recitation of Shakespearean verse is given all the necessary attention

\footnotetext{
${ }^{2}$ See Sherlockology for Metro.co.uk (2016), Shepherd (2016), Ordóñez (2012).

${ }^{3}$ The Extra Features in the Spanish DVD Box-Set of Game of Thrones include a documentary entitled "La Verdadera Historia detrás de Juego de Tronos." In this short documentary, George R. R. Martin as well as a number of historians explain the resemblances between several characters in Game of Thrones and many characters in the two H enriads.

${ }^{4}$ Goold's recent production of Richard III at the AImeida Theatre opens with a group of archaeologists working on an excavation in the middle of the stage. Before the performance begins, they extract what unmistakably looks like Richard's extremely twisted spinal column.
} 
on the small screen..$^{5}$ In many scenes, such as the public sequences taking place at Westminster Hall, the actors have the chance to display their vocal and physical projection in conditions very similar to those of the theater stage. Thus, Cooke clearly states that, just because the recording is filmic, it does not involve sacrificing the textual power of the play-texts. ${ }^{6}$

The other great strategy followed was the visual mapping of various themes and images which help achieve cohesion and coherence in the complex operation of blending four plays to form a single narrative arch. Firstly, the film makes ample use of icons that appeal to popular audiences. A multi-generational cast of British theater and television talent is featured. Very often, these artists come in pairs. That is the case of Cumberbatch and Andrew Scott (King Louis of France; BAFTA winner for his acclaimed Jim Moriarty), both of them stars in Sherlock. This also applies to the stars of A shes to A shes, Philip Glennister and Keeley Hawes, who play the champion John Tal bot and the Lady Elizabeth Grey respectively.

Reviewers have highlighted Cumberbatch's performance as Richard III. Contrarily to recent film adaptations of Richard III, this series offers Richard's journey from his youth to his tyrannical rule. As Richard Plantagenet (Adrian Dunbar) challenges King Henry (Tom Sturridge) and rides to his home, he discovers his sons Edward and George practicing sword-fighting. A medium shot shows the sinister, deformed and swinging figure of Richard attending his father's call in what seems akin to a horror film closure of the first episode. Later on, in the third episode, we can for the first time see Richard's naked body as we see the repulsive hump on his back. Also, very frequently, Richard suffers the horrible pains of scoliosis and arm paralysis. Although the character is depicted as dreadful, we can perceive some of Sherlock's persona in how his humorous sociopathy is often played out in the figure of this monarch who sits down in chambers below the ground and furiously finger-taps on the table as his wife Lady Anne and the two Princes are murdered in the London Tower.

\footnotetext{
${ }^{5}$ According to Charlotte Brunsdon, British quality television is endowed, amongst others, with two main assets: the "literary source" and "the best of British acting" (1990, 85-86).
}

${ }^{6}$ See "The Making of The H ollow Crown: The Wars of the Roses" in DVD (2016). 
Cooke employs a number of other iconic features that are recurrent through the film. The white rose and the red rose are constantly referred to through banners, heraldry motifs, battlefield markers, tapestries, and colors worn by soldiers of the different factions. Following suit with the first episode in the first series, a Plantagenet genealogy is shown by Mortimer (Michael Gambon) as he explains to Plantagenet that he is the true inheritor to the English crown. Yet, perhaps the most repeated icon is the crown that gives its name to the series. Passing from one hand to another, very often this coveted object is given close-ups and a life of its own. The object even undertakes its own journey as Henry VI throws it into the river and afterwards it is retrieved by Warwick's men.

The use of iconicity extends to the representations of landscapes, a theme which has come to be mandatory in any British historical series. Unsurprisingly, in line with a Tillyardian reading of the plays, the first episode commences with a view of the Dover cliffs and Cooke allows himself some poetic license in letting the viewer hear Judy Dench reciting part of Ulysses' speech in Troilus and Cressida (1.3.107-13). It is indeed significant that the opening aerial shot in the first episode features the White Cliffs of Dover, an icon of Britishness often displayed in film in opposition to the continent. Also, it is indeed noteworthy that Ulysses' speech on hierarchy is used at a time in which Brexit supporters challenge the European hegemony and order.

A series of other British locations are, likewise, exhibited. Amongst these, I would like to highlight the Tower of London, which is very often accessed through the so-called Traitor's Gate by boat so that, by way of reiteration, the viewer is invited to infer that somebody in the tower is going to be executed. Even in those realistic settings, Cooke does not let us forget that characters like Richard Gloucester need to constantly interact with the audience. Thus, Cumberbatch directly addresses the viewer as he is taken by boat through the Traitor's Gate. Also, he addresses us as he explains his plans to take "the English Crown." Afterwards, after savagely and repeatedly stabbing King Henry, he comes to us again to share his Ioneliness and lovelessness with the viewer (cf. King Henry VI Part 3, 5.6.68-93).

Pursuing this hybrid balance of theater, film and television, the series acknowledges that in filmic terms realism is something to be 
pursued. ${ }^{7}$ Therefore, long scenes are broken down into smaller sequences that provide realism and different settings: a hunting park, a shooting field, a tennis court, and a plethora of authentic locations. Montage is very often employed in narrative speeches in order to show what a character is revealing, and parallel sequences are featured. An instance of this appears in the first encounter between Talbot and La Pucelle at Rouen, as the two leaders deliver parts of their respective speeches to the soldiers. This filmic resource is employed again when King Richard and Henry Richmond deliver their battle speeches at Bosworth in an alternating sequence of parallel shots. Sometimes even experimental shots, such as the helmet camera shot opening in media res the second episode, appear, in this case featuring a street battle.

Attention has been paid to how Cooke chooses visual effect, spectacle and realism in battle scenes. Following realistic rather than theatrical metonymic premises, Cooke personalizes every battle. Thus, the battle of St. Albans takes place in the streets of the town. ${ }^{8}$ A nother battle takes place on the river and King Henry VI hides amongst the bushes spying on the soldiers walking on the water while rivers of blood fill the screen. Surprisingly, the scenes where the Old Man and the Young Man respectively discover their filicide and parricide are preserved in this production too (King $\mathrm{H}$ enry $\mathrm{VI}$ Part 3, 2.5.55-93). The battle of Tewkesbury is filmed in the woods and flies buzz around the corpses left hanged as the three York brothers look like three hairy wolves howling and rejoicing in their zest for violence.

Taking a look at the postcolonial controversies that also connect to Brexit, perhaps it is significant that Sophie Okonedo, a British black actress of Nigerian descent, portrays the "shewolf of France" (King Henry VI Part 3, 1.4.111). If we accept the premise that there is

\footnotetext{
${ }^{7}$ Regarding the hybridity of the series, Rupert Ryle-Hodges, executive producer of the series, says: "It's a very interesting thing to work on because it's a mixture of theater, film and television. I really enjoy the fact that there aren't the usual boundaries you get between the three disciplines. I've not worked in the theater before, but I feel that there's so much which comes from the theater which influences how we made this" (See "Directing and Producing Shakespeare's The H ollow Crown: The W ars of the Roses" 2016).

${ }^{8}$ As Cooke confirms, St. Alban's battle historically took place in the town ("Directing and Producing").
} 
no such a thing as color-blind casting, this actress serves to present Margaret of Anjou as an object of sale ruthlessly waged by a sensual and cynical Somerset (Ben Miles) and a degraded Duke of Anjou (David Troughton). Nevertheless, Margaret's otherness is played out as her fierceness and impetus for hunting, archery and, eventually war, are represented on many occasions. Is this perhaps a striking allusion to the recent "unleashed racism" in Great Britain? Or is it perhaps a means to express the renewed distrust between the East and the West as well as the shameful part played by Europe in relation to refugees?

All in all, as mentioned above, the film makes significant textual sacrifices, and thus many of the complex subplots and theatrical achievements in each of the four plays are sacrificed for the sake of clarity and narrative pace. However, Cooke manages to keep up a straightforward storyline that may seem rather repetitive in some respects-the chessboards, the coronation ceremonies, and the Tower of London may seem a bit overused-but he manages, on the other hand, to individuate the complex map of characters in the film. All these characters who very often simply appear in the screenplay as "place names"-Suffolk, Somerset, York, Gloucester, etc.-are nicely clarified through the selection of strong interpreters who, with very brief appearances on screen, can create differentiated figures, thus resolving Al Pacino's complaint about the difficulty of understanding the entangled web of characters in The Wars of the Roses. ${ }^{9}$

\section{References}

Brunsdon, Charlotte. 1990. "Problems with Quality." Screen 31(1): 67-90.

"Directing and Producing Shakespeare's The H ollow Crown: The Wars of the Roses." bbc.co.uk. Accessed 2016. http:// www.bbc.co.uk/ academy / production/ television/ article/ art20160512135013337.

The Hollow Crown. Directed by Rupert Goold, Richard Eyre, Thea Sharrock. 2012. Neal Street Productions, NBC Universal, WNET. DVD.

The H ollow Crown: The Wars of the Roses. Directed by Dominic Cooke. 2016. Neal Street Productions, NBC Universal, WNET. DVD.

\footnotetext{
${ }^{9}$ A part from the linguistic difficulty in Shakespeare's text, AI Pacino points out that a major difficulty in interpreting Richard III comes from the genealogical complexities of the previous three plays. See Looking for Richard (1996).
} 
Ordóñez, Marcos. "The Hollow Crown: Otra Lección." elpais.com. Last modified 12 September, 2016. http:/ / cultura.elpais.com/ cultura/ 2012 / 09/ 12/ actualidad/ 1347469381_042897.html.

Shakespeare, William. 2006. Troilus and Cressida. Edited by David Bevington. London: Thompson Learning.

- - - 2013. King Henry VI Part 3. Edited by John D. Cox and Eric Rasmussen. London and New York: Bloomsbury Arden Shakespeare.

Shepherd, Jack. 2016. “The Hollow Crown: The Wars of the Roses: Benedict Cumberbatch says filming the latest William Shakespeare adaptation was 'brutal'." independent.co.uk. Last modified 8 May, 2016. http:/ / www.independent.co.uk/ arts-entertainment/ tv/ news/ thehollow-crown-the-wars-of-the-roses-benedict-cumberbatch-williamshakespeare-brutal-bbc-henry-vi-a7018931.html .

Tillyard, E. M. W. 1974. Shakespeare's History Plays. London: Chatto \& Windus.

"Why Sherlock Fans Should Watch Benedict Cumberbatch in BBC Shakespeare Adaptation of The Hollow Crown: The Wars of the Roses." metro.co.uk. Last modified April 28, 2016. http:// metro.co.uk / 2016/ 04/ 28/ why-sherlock-fans-should-watch-benedict-cumberbatchin-bbcs-shakespeare-adaptation-the-hollow-crown-the-wars-of-the-roses5844279/ .

How to cite this review:

Huertas Martín, Víctor. Review of Dominic Cooke, dir. The Hollow Crown: The W ars of the Roses (BBC, 2016). SEDERI 27 (2017): 231-37.

A uthor's contact: victor.huertasm@uam.es

Postal address: Dpto. Filología Inglesa - Facultad de Filosofía y Letras - Universidad Autónoma de Madrid - Campus de Cantoblanco - 28049 Madrid, Spain 


\title{
Sonia Hernández-Santano, ed. 2016 William Webbe, A Discourse of English Poetry Cambridge: M odern Humanities Research A ssociation.
}

\author{
Rocío G. Sumillera \\ U niversidad de Granada, Spain
}

Before the appearance in print of the most renowned works on poetics of sixteenth-century England, George Puttenham's The A rt of English Poesy (1589) and Sir Philip Sidney's The D efence of Poesy (1595), William Webbe had published A Discourse of English Poetry (1586), now acknowledged as one of the first attempts in England to write a systematic and comprehensive poetics and to establish a national poetic canon. Webbe, who composed A D iscourse over the summer of 1586, was very likely unaware of Sidney's D efence, although it had been circulating in manuscript form since the beginning of the decade. As he confesses somewhat apologetically in the prefatory texts to his work, he was removed from the literary circles of London, which he says prevented him from reading some of the works he mentions and which he only knows by reputation. Webbe ponders the nature of poetry, essentially following Horace's A rs Poetica, and enthusiastically advocates a reformation in the direction of classical metres. In doing so he particularly encourages the two authors whom he hails as the paradigms of English poetry, i.e. Gabriel Harvey and Edmund Spenser, to take the lead.

Over a century ago George Gregory Smith included in his Elizabethan Critical Essays (1904) an edition of Webbe's treatise, which stood as the most recent attempt to edit Webbe's work until in 2016 Sonia Hernández-Santano published her conscientious modern-spelling version, accompanied by a thorough critical apparatus. The text of Hernández-Santano's edition is the result of collating that of the only original edition of Webbe's A D iscourse (printed jointly by John Charlewood and Robert Walley in 1586) with the old-spelling editions by Smith (1904), Edward Arber (1870) and Joseph Haslewood (1815). Hernández-Santano's edition furthermore includes the only other extant works by Webbe, to wit, his "translation of Virgil's Eclogues I and II in hexameters together with his rendering into Sapphic verse [of] Spenser's 'Song to Elisa' (from Calendar, 'A pril')," plus, the “Ap- 
pended translation of Georg Fabricius' 'Canons' on poetry as derived from Horace's A rs P oetica" (10).

Four are the contemporary works that shape Webbe's A Discourse: Thomas Elyot's The Boke N amed the Governour (1531), Roger Ascham's The Schoolmaster (1570), Thomas Phaer's translation of the A eneid (1573), and Spenser's The Shepherds' Calendar (1579). Each of them is employed by Webbe for different purposes. Thus, Elyot's work "constitutes a primary source of arguments and textual examples for Webbe's defence of poetic didacticism," and moreover it lends "authority to his choice of ancient poets who best serve instructive purposes" (8). The Schoolmaster, for its part, "provides Webbe with the appropriate discursive tools to hail literature as the principal idiom for the articulation of a mature cultural identity that would raise the English nation to the same status as the ancient empires" (7). Phaer's translation "provides Webbe with enlightening poetic exempla when it comes to demonstrating that the English tongue is capable of the rhetorical eloquence of classical texts" (8), while from The Shepherds' Calendar, "rendered in A Discourse as the most outstanding evidence of poetic proficiency" in English, Webbe extracts "all sort of exempla so as to illustrate every aspect of his humanist definition of poetry" (8). "Spenser, whose authorship Webbe does not openly assume," is, as Hernández-Santano asserts, "extolled both as an innovator [...] and as a consolidator of the canon of English national poetics, equated in this regard to Virgil for his success in transforming his vernacular language into a dignified instrument of poetic expression" (33).

In the instructive Introduction to her edition, Hernández-Santano devotes the two independent sections following the "Preliminary Considerations" precisely to discuss the extent of Ascham, Elyot and Spenser's influence upon Webbe: "2. The Humanist Context of A Discourse: Roger Ascham's The Schoolmaster and Thomas Elyot's The Governour" and "3. William Webbe and Cambridge Ideals: Canonizing Spenser's The Shepherds' Calendar." These are followed by "4. A Defence of the Quantitative Reformation of English Verse," where Webbe's ideas on versification, and his exhortation to experiment with quantitative meters, in decline among many poets save for exceptions such as A braham Fraunce, are explained in detail.

A Discourse was ultimately "conceived as a prescriptive manual on versification that provides practical instructions and examples so 
as to, on the one hand, contribute to the refinement of rhyme and, on the other, allow a coherent adaptation of Latin rules of prosody to English verse" (8-9). Webbe's zeal in his advocacy of classical hexameters, decades before promoted by the Cambridge circle (initially structured around Ascham, John Cheke and Thomas Watson), suggests that he was unaware that such specific reformation of verse was, by the time of the publication of his treatise, in decay if not dated-again with exceptions such as the younger generation of St John's College. Still, as Hernández-Santano rightly notes, there may be more to Webbe's work than the staunch defense of a particular form of versification: “Webbe's commentaries do not seem to be a neutrally descriptive catalogue of contemporary literary authorities; instead, from most of them the reader may infer Webbe's desire to be noticed by those to whom he alludes, both by publidy recognizing their merits, and by displaying his remaining links with the Cambridge world. Whether he intended to obtain patronage and to be accepted at an Inn of Court, or simply aspired to be accepted by the literary elite at whose apex he situated Harvey and Spenser is difficult to ascertain" (29-30). Hernández-Santano's edition closes with a "Textual Notes" section, which complements the abundant and exhaustive footnotes to the text, a "Glossary" containing obsolete or archaic terms, and a helpful updated bibliography of scholarship on Elizabethan literary theory.

\section{References}

Smith, George Gregory. 1904. Elizabethan Critical Essays. Oxford: Clarendon.

Arber, Edward, ed. 1815. W. Webbe, A Discourse of English Poetrie. Together with the A uthours iudgment, touching the reformation of our English Verse. London: English Reprints.

Haslewood, Joseph, ed. 1815. Ancient Critical Essays upon English Poets and Poësy. London: T. Bensley for Robert Triphook.

How to cite this review:

Sumillera, Rocío G. Review of Sonia Hernández-Santano, ed. William W ebbe, A D iscourse of English Poetry (Cambridge: Modern Humanities Research Association, 2016). SEDERI 27 (2017): 239-41.

A uthor's contact: sumillera@ugr.es

Postal address: Dpto. de Filologías Inglesa y Alemana - Facultad de Filosofía y Letras -

Campus Universitario de Cartuja s/ n - 18071 Granada - Spain 


\title{
Robert D. H ume and Judith M ilhous. 2015. The Publication of Plays in London 1660-1800: Playwrights, Publishers and the Market. London: The British Library
}

\author{
Jorge Jiménez Rodríguez \\ U niversidad de Sevilla, Spain
}

It would be advisable to consult Hume and Milhous' massive study before making any assumptions about the material aspects of play publication in the seventeenth and eighteenth centuries. Not only do they provide the empirical foundation from which further research might be conducted, but in doing so they carry out a thorough review of criticism that is immensely useful. It provides the reader with a very accurate view of the evolving ideas on playwriting in earlier works, rescuing important studies such as A lbright's D ramatic Publication in England 1580-1640 (1927) that have not enjoyed the success they deserved even if they have undoubtedly contributed to our current perceptions of early modern literature. Their statistical analyses constitute a basis for questions on issues such as readership, publication processes, anonymity, performance, economics of patronage, the sociology of playwriting and the advertisement of plays, allowing us to understand them in their own contexts of production and publication. Their work provides a solid structure that contrasts starkly with the interpretative trend in cultural and literary studies today, bridging the gap between speculation and a much needed scientific approach to literature. The Publication of Plays in London expands on their Panizzi Lectures delivered at the British Library (2011) and must be regarded as the culmination of a life-long career dealing with periods of dramatic activity that are often overlooked.

Hume and Milhous' partnership has been a major reference in Restoration drama criticism for a few decades. As for the material aspect of playwriting (namely distribution and the printing process), Hume's previous studies have laid the groundwork on which serious research might be based. The first part of the book deals with publication issues, including an introductory chapter on the emergence of the printed play-text in the early Elizabethan period. 
Part I proper begins in 1660 and covers the movement from quarto publication (1660-1715) to octavo and duodecimo (1715-1800). Part II is entirely devoted to financial contexts such as the price of plays and playwright's remuneration across the two periods. Finally, Part III analyzes the phenomenon of catalogues, reprints, collections and illustrations, which hitherto has not received much scholarly attention. This volume thus stands in an advantageous position, as it enables the authors to situate the Restoration period in a continuous timespan from the establishment of the theater business in Elizabethan times onwards.

In the first section, Hume and Milhous devote themselves to debunking misleading assumptions on questions of authorship and publication prior to 1660 . This allows us to observe the development of performance and publication rights and the changes leading to the establishment of the "third night profit" convention and the right of playwrights to peddle scripts to publishers and booksellers, which would have a tremendous impact in the professionalization of the theater. They provide an interesting insight into the Actor's Rebellion of 1694 as signaling the moment when performance rights became less fixed. They discuss Roger L'Estrange's status as a controversialist and the effects on licensing rights for professional playwrights, while also observing how King William's lax attitude towards playhouses managed to overthrow the claims of the United Company to the stock of pre 1645 works without raising complaints. Also, they manage to illustrate how booksellers secured a de facto perpetual ownership of the intellectual property of playwrights by allowing them to make only a single payment and how the turbulent political situation settled this state of affairs regardless of the passing of the Copyright Act (1710).

Even when Milhous and Hume base their conclusions on assumptions rather than statistical data, we are inclined to trust their well-established expertise as their management of evidence is clear enough to garner support for their intuition. Their guess that D'A venant and Killigrew thought up the business scheme whereby patent companies put the risk entirely on the playwright while creating a market for aspiring gentlemen not only accounts for the careers of the likes of Dryden and Shadwell, but proves difficult to deny given the historical evidence and the situation confronting them at the reopening of the theaters. They successfully prove that 
the involvement of playwrights in the printing process rose steadily from the 1660s onwards, yet they manage to include minor exceptions in constructing the big picture. The figures provided also show ground for a narrowing time lapse between performance and publication and the development of advertisement strategies coinciding with the rise of the newspapers or the commodification of cast lists and separate prefatory material at the turn of the eighteenth century. The material context of publication is well accounted for, as they provide a really good mapping of major publishing houses as well as changes in print runs and bookselling techniques. To my mind, their most important contribution rests on providing a solid foundation for future studies in authorship and the professionalization of the literary trade. The movement from collaborative and anonymous authorship to solo publication provides an explanation for the changing status of the playwright best seen in the appearance of major folio collections prior to the 1660s, as well as the posthumous collected works of D'A venant and Dryden, which indicate that plays had come to be seen as bearers of literary value.

As they move into the eighteenth century, their consideration of piracy and its effects on the change towards octavo and duodecimo formats by competing publishing operations is also developed. The collapse of licensing regulations and the failure to impose the Copyright Act paved the way for what they recognize as the "decline in the aesthetic and intellectual ambitions of playwrights" (120) which is marked by the enforcement of Walpole's Licensing Act (1737). The lowering of literary standards is explained through the reestablishment of a competing duopoly, crushing the competition posed by small venues like Little Haymarket and accommodating new performances to larger crowds, to whom a dialogue-based piece might have not seemed easy to follow. The new theater gave rise to new theatrical forms that were constantly adapting their public appeal to achieve maximum profitability. Hume and Milhous also discuss marketing differences between octavo singletons and popular opera libretti, which leads them to question "what qualifies as a play," excluding musicals and afterpieces that might skew the figures that mainly affect play publication for the purpose of their analysis. 
Hume and Milhous' materialistic approach is comprehensive but not overly ambitious. They recognize the inaccuracy in settling matters such as the relationship between printed versions and performance texts. Moreover, when they move to the realm of pure economics, they must admit the difficulty of establishing a stable comparison between seventeenth- and eighteenth-century sterling values and modern currency, which is also subject to all sorts of inflations and devaluations-for instance, some of the evidence we have for a playwright's earnings is given in broad-pieces, which had a face-value of 20 shillings, but rose to 23 by the end of the seventeenth century. They reject the argument of the affordability of playbooks. This leads to further assumptions about how much profit playwrights and booksellers could make selling luxury items, which in turn implies a much more reduced readership and hence subscription figures than those which have previously been assumed. It also has certain implications regarding a playwright's remuneration, which included the price obtained from the publisher, plus third and sixth night benefits and favors from prospective patrons.

The last part of the book deals with the purely material aspect of reprints and their status as empirical data, particularly in the case of eighteenth-century publishers like Tonson and Bell. This aims at vindicating the role of neglected reprints and collections as source material for investigation, a call to arms against the sole authority of first editions in research and a reminder that they often limit our views of the development of theatrical and literary practices. This volume includes a collection of appendixes, tables and figures for further research, namely a list of copyright payments for plays, a list of titles included in major multi-author collections, a series of copyright transfers (Lintott's and the Upcott collection), the publication order of Bell's British Theatre series (1791-1797) and a list of bibliographical resources that have helped shape this astonishing work. We are all of us indebted to Hume and Milhous for illuminating the darkness that often shrouds our perception of the publishing world in two crucial periods for the development of British drama. ${ }^{1}$

\footnotetext{
${ }^{1}$ The author wishes to acknowledge funding for this review from the Spanish government (MINECO ref. FFI2015-68376-P).
} 
(5) ederi 27 (2017)

H ow to cite this review:

Jiménez Rodríguez, Jorge. Review of Robert D. Hume and Judith Milhous. The Publication of Plays in London 1660-1800: Playwrights, Publishers and the Market (London: The British Library, 2015). SED ERI 27 (2017): 243-47.

A uthor's contact: geximro@gmail.com 


\title{
John K nox. 2016. El primer toque de la trompeta contra el monstruoso gobierno de las mujeres. Edited by José Luis M artínez-D ueñas and Rocío G. Sumillera $\mathrm{V}$ alencia: Tirant $\mathrm{H}$ umanidades
}

\author{
Carme Font Paz \\ U niversitat A utònoma de Barcelona, Spain
}

Bibliography on John Knox, the Scottish Reformation, and the theol ogical underpinnings of Presbyterianism has not been scarce in the last fifty years, with a weal th of articles, biographies, and booklength studies that have contextualized Knox's extensive production, as shown in David Laing's 1895 edition of Knox's works in six volumes or an illustrated Life by Thomas McCrie in 1814. Recent biographies (Percy 2013; Marshall 2008) are concerned with different episodes in Knox's life and his pastoral mission, while Jane Dawson's biography (2016) delves into unearthed correspondence between Knox and his friend Christopher Goodman during his "Frankfurt Troubles," the first textual discovery on Knox since 1875 that puts him, as Dawson suggests, in a more intimate and nuanced light. It might come as a surprise that one of Knox's more famous and controversial texts printed anonymously in his lifetime, The First Blast of the Trumpet against the M onstruous Regiment of Women, does not have a stand-alone annotated edition in English. It has hit the commercial market, though, with the "The Knox Trilogy" fiction series by Marie Macpherson (2012), aptly entitled The First Blast of the Trumpet and its two sequels, The Second and The Third blasts.

Despite the deafening flurry of his words and deeds, Knox's theological contribution as a key figure in the Reformation is established on solid ground, but the character and mind-frame of Knox the man is still elusive. Texts such as The First Blast have hindered, as Dawson suggests, a multifaceted and accurate version of Knox since scholars have tended to correlate the antagonistic arguments against female rule in The First Blast with a general acrimony against women. Was Knox a lover or a hater of women? 
How can we make sense of his intellectual respect and attachment to Anne Locke (1530-1590), the first woman to compose a sonnet sequence in English, with his arguments about women's natural inferiority in The First Blast? And perhaps more importantly, what repercussions do these apparent discrepancies between the discourse against women and the dealings with women have on the study of women's writing and social status in the context of the Reformation? These are questions that warrant a thorough analysis not only of Knox's biography, however brilliantly accomplished in Dawson's book, but an assessment of Knox's textuality inscribed within a Reform culture in the making, with the political, national and class tensions which he himself endured and provoked.

It is just timely that José Luis Martínez-Dueñas and Rocío Sumillera's translation and edition of The First Blast has been published with a brilliant introductory study that illuminates some of these critical areas in Knox studies. There are no translations of Knox's works into Spanish, an omission that can be traditionally explained by the political and religious animosity between radical reformist factions and Spanish Catholics, but that can no longer hold in a twenty-first century context despite the low incidence of Presbyterians in Spain (perhaps somewhat higher in a Latin American context).

The "Estudio preliminar" of El primer toque elaborates on the main episodes in Knox's biography, his family origins and education at St Andrews, his conversion to Protestantism in the 1540s under the influence of George Wishart, who was burnt at the stake in 1546, and his early pastoral activity in Berwick after his nineteen-month sentence in the galleys. His inspired sermonic activity in the 1550 s drew the attention of John Dudley, duke of Northumberland, and of a group of merchants in London and their wives, to whom Knox often gave spiritual counsel. His reformist leanings did not match the political developments in England at that time, when Mary I had imprisoned the Archbishop of Canterbury, Thomas Cranmer, and Protestants were burnt at the stake in Tyburn and Smithfield. Knox set out for the French city of Dieppe in 1554, and there he wrote letters to the "afflicted church of Christ" before he settled in Frankfurt, where a community of some two hundred English exiles had sought refuge. Martínez-Dueñas and Sumillera do not del ve into the particulars of Knox's troubles in Frankfurt, where his sermons on 
the particular liturgical practices of the exiled English church and his fierce criticism against the ineffectiveness of British Reform in the reign of Edward VI started a backlash that forced him to leave for Geneva. There he helped out in the edition of the Geneva Bible with his notes, parted with Calvin and became pastor of the congregation together with his friend Christopher Goodman. He also wrote two political treatises and The First Blast during a short stay in Dieppe before returning to Geneva. It was around this time when Knox configured his authorial voice as that of a prophet. While this is an aspect of Knox's scholarship that has long been noted and related to the political use of "social prophecy" in the context of English reformers, Martínez-Dueñas and Sumillera consider it a distinctive trait of Knox's style that connects his religious and political thought, and is recurrent in his text: "Este precepto, digo, con la amenaza añadida, junto con lo demás de lo que se habla en el mismo capítulo, no sólo a Ezequiel sino a cada uno a quien Dios coloca de guardián de su pueblo y su rebaño (y guardianes son aquéllos cuyos ojos Él abre y cuya conciencia Él azuza para exhortar al impío), este precepto me obliga a expresar mi conciencia sobre este asunto" (125). Knox is aware of his role as a prophet and his conscience as being a moral guide through which his connection with the divine is expressed. Martínez-Dueñas and Sumillera's analysis illustrate this point as it is articulated through the relationship between gender and political theory. When Knox threatens that "Ios hombres que reciban de mujer autoridad, honor o cargo, quedan con toda certeza persuadidos de que al mantener así el poder usurpado se declaran enemigos de Dios" (172), he is not suggesting a rebellion against women or the state, but an action against tyranny which is a responsibility shared with the people. It is an act of disloyalty towards God to keep in place a ruler whose deeds run contrary to $\mathrm{Him}$, thus inverting the classical concept of rebellion against the monarch: "Si la rebelión primera y auténtica es la del tirano contra Dios, la rebelión segunda, la de la nobleza o el pueblo contra el tirano, no es tal, pues supone la defensa de la ley de Dios" (46). Being essentially a Calvinist position, this is an apt reminder that contract theory between king and humanity is mediated by God, through men's conscience, and that later arguments in favour of regicide in the seventeenth century with Charles I had necessarily to justify themselves in religious terms. Although Knox was tapping into sixteenth-century theories of resistance, as the authors of the 
introduction rightly remark, this did not prevent him from receiving all manner of criticisms from other ministers of diverse Protestant leanings.

Martínez-Dueñas and Sumillera's study includes a thorough selection of reactions to Knox's text, and one by the minister Matthew Parker, who had not been in exile, shows outrage at a sentence he read in one of the books he had browsed in his last visit to London: "Una dama no puede ser por la palabra de Dios gobernante de un reino cristiano" (85). Parker's reaction is revelatory in that it points at a discrepancy between a misogynistic discourse and one that uses the tradition of literature against women to justify a political view. Knox had to print a "note to the reader" soon after the publication of The First Blast acknowledging himself as the author (since the tract had been published with no reference whatsoever to author, imprint, or place of publication). Knox had intended to reveal this information in a Third Blast, but he could not even complete a second one. Martínez-Dueñas and Sumillera's introduction details accurately the correspondence about this matter between Calvin and Elizabeth I, through her secretary of state William Cecil. Soon after she came to the throne upon the death of Mary I, she had to establish her political position in the face of powerful enemies. The First Blast did not contribute to it and, regardless of what Elizabeth I might have thought of Knox's verbal tirades against women, political muscle was her primary concern. Thus she let it be known to Calvin, who replied in a long letter with the hope of dissipating Elizabeth's mistrust towards exiled British Protestants in Strasbourg and Geneva. Calvin pointed out that Knox's published his First Blast without his knowledge or consent, that he did not subscribe to the tenor and opinions in it, and that Knox might have wrongly interpreted a conversation they once held about women and political power. Calvin's justification did not convince Elizabeth, who would bear him a grudge for life, but at least it did not make matters worse. Again, Martínez-Dueñas and Sumillera convincingly argue that Knox overdid his misogynist ranting by believing that this would benefit the political stance of the Protestant cause, but he miscalculated the fact that a Protestant queen would be next in sitting on the British throne. We may add to the authors' analysis that what these reactions further suggest is that blunt misogynistic remarks were no longer accepted in the halls of realpolitik. 
Martínez-Dueñas and Sumillera's translation into Spanish reads very fluently and keeps the original tone of sermonic denunciation, preserving the argumentative force of Knox's abundant biblical references as a subtext, which the editors annotate and expand in footnotes that do not smother the original text. With this edition and complete introductory study, the authors have made a much-needed contribution to Knox studies within a Spanish context while entering a dialogue with Knox's finest scholarship in its original.

\section{References}

Dawson, Jane. 2016. John Knox. N ew Haven: Yale University Press.

Eire, Carlos. 2016. Reformations: The Early Modern World 1450-1650. New Haven: Yale University Press.

Gordon, Bruce. 2011. Calvin. New Haven: Yale University Press.

Laing, David, ed. 1895 (2009). The Works of John Knox. Ithaca, NY: Cornell University Press.

Marshall, Rosalind Kay. 2008. John Knox. Edinburgh: Birlinn.

Mason, Roger A. 1994. John Knox on Rebellion. Cambridge: Cambridge University Press.

McCrie, Thomas. 1814. The Life of John Knox. Edinburgh: Printed for John Ogle.

Percy, Lord Eustace. 2013. John Knox. Cambridge: The Lutterworth Press.

How to cite this review:

Font Paz, Carme. Review of John Knox. El primer toque de la trompeta contra el monstruoso gobierno de las mujeres. Edited by José Luis Martínez-Dueñas and Rocío

G. Sumillera. (Valencia: Tirant Humanidades, 2016). SED ERI 27 (2017): 249-53.

A uthor's contact: Carme.Font@uab.cat

Postal address: Departamento de Filología Inglesa y Germanística - Edifici B - Campus de la UAB - Universitat A utònoma de Barcelona - 08193 Bellaterra, Cerdanyola del Vallès (Barcelona) - Spain 


\title{
Zenón Luis-M artínez, ed. 2016. Abraham Fraunce. The Shepherds' Logic and Other Dialectical Writings. C ambridge: M odern H umanities Research A ssociation
}

\author{
Jonathan P.A. Sell \\ Universidad de A Icalá de H enares, Spain
}

As the rear cover blurb proclaims, this volume is the first published critical edition of the three works by A braham Fraunce (1559?-1593?) on the art of logic contained in the manuscript preserved in the British Library as Add MS 34361. It is to Luis-Martínez's great credit that he has made these little read texts available in book form to a prospective audience which would hitherto either have had to make the trip to Euston Road or apply to Saint Louis University for a copy of Sister Mary M. McCormick's (1968) unpublished critical edition of the same three texts. Luis-Martínez (3) pays due tribute to McCormick's work, but his own edition will henceforth become the standard Shepherds' Logic for generations to come. In this sense it is no great exaggeration to say that Luis-Martínez is a twenty-first century counterpart to the great nineteenth and early twentiethcentury philologist-editors of early modern English rhetorical texts. As Luis-Martínez will probably be the first to admit, the texts presented here are not of the stature or importance of, say, Thomas Wilson's The Arte of Rhetorique (1553, 1560) or George Puttenham's The Arte of English Poesie (1589), which found their editorial champions in G. H. B. Mair (1909) and Gladys Willcock and Alice Walker (1936), respectively, although Fraunce himself, Ramists in general and, perhaps, Luis-Martínez might object to my bracketing of Fraunce's logical writings with others on rhetoric; but like Francis Bacon's fly on the axle-tree of history, Fraunce and countless other second or third-division authors were capable of kicking up an awful lot of dust, and it is often the common dust of the literary journeymen rather than the glittering pinnacles of high art rising above it which is of greater historical interest.

The major difference between McCormick's and Luis-Martínez's editions is the latter's decision to provide a modern-spelling version, which, we are told (49), is the result of collating the original 
manuscript with McCormick's old-spelling edition and parallel passages in Fraunce's The Lawyers' Logic (1588). Perhaps unnecessarily - we have been brought up quite happily on modernspelt Shakespeare, Sidney and Donne, while some academic journals insist on modern spelling for quotations from original sourcesLuis-Martínez justifies his decision by adducing the similar modus operandi of recent editions of Puttenham's The Art of English Poetry (2007) and William Scott's The M odel of Poesy (2013), the idea being that modern spelling will neither offend the specialist nor put off the "beginning graduate student." That said, modern-spelling editions can run into difficulties when differentiating between issues of orthography and morphology. Words as ordinary as "moe" (more) and "fet" (fetched) are here transcribed as found, and the reader is referred to the Glossary, usefully appended to the texts; but would any harm be done if they were given their modern forms in the transcription?

Luis-Martínez's thorough and up-to-date Introduction means that few will need to consult what he calls deferentially McCormick's "illuminating account" (3) of the Ramist context. Based on thorough knowledge of recent Ramus-related scholarship, all duly listed in the comprehensive Bibliography, it provides a useful account of English Ramism; says all that can be said about Fraunce's life, works and literary legacy; considers carefully the vexed issue of dating (opting for 1583 or very early 1584 for The Shepherds' Logic); analyses the evolution of Fraunce's logical thought from The Shepherds' Logic to The Lawyers' Logic; discusses the relationship between dialectic (the second art of Ramist logic, the first being invention) and rhetoric with reference to The Shepherds' Logic and Fraunce's A rcadian Rhetoric (1588), and between logic, poetry and poetics with reference to Edmund Spenser's The Shepherds' Calendar and The Shepherds' Logic; briefly introduces the two other logical texts that complete British Library Add MS 34361, namely, "Of the Nature and Use of Logic" and "A Brief and General Comparison Between Ramus his Logic and that of Aristotle"; and finally explains the procedures followed in editing the texts.

Several points of interest emerge from all this which illuminate various aspects of English literary and intellectual culture in the 1580s. The failure of Fraunce's logical writings to secure the patronage of Sir Philip Sidney (like him, a former pupil of 
Shrewsbury School), who in 1585 made another Cambridge Ramist, William Temple, his personal secretary, is a reminder of the precarious hand-to-mouth existence of university graduates with no, or only very tenuous, personal connections. That two graduates should vie for patronage on the strength of Ramist logical works (Temple's edition and commentary on Ramus's Dialectica was published in 1584) is an indication of how hot an issue among the intelligentsia of the day was the Ramus versus Aristotle debate, which from our vantage might seem like a storm in a cold cup of tea. In this respect, Fraunce's anti-scholastic, anti-monkish and therefore anti-Catholic invective, which Luis-Martínez suggests (146n7) was inherited from Thomas Norton's 1561 translation of Calvin's Institution of Christian Religion, was perhaps too trenchant for Sidney's patrician demeanor and courtly savoir faire. On the other hand, in the broader context of philosophical history, the empiricism of Fraunce's apparently original account of logic's origins anticipates what would later distinguish British thought from the continental tradition. In a trio of writings that draw heavily on Ramus's own works, on Friedrich Beurhaus's two volumes of commentary of them, and, particularly, on Johannes Piscator's In P. Rami Dialecticam A nimadversiones (1580), which steered something of a middle course between Ramus and Aristotle, to come upon what seems to be Fraunce's own voice in the following passage from "Of the Nature and Use of Logic" (recommended as entertaining first port of call for readers before embarking on The Shepherds' Logic) is a welcome breath of fresh air:

That therefore is true Logic, which is agreeable to reason imprinted in man, and apparent in the writings, arguments and disputations of the most excellent in every kind, as Plato, Aristotle, Demosthenes, Cicero, Homer, Virgil and such like, whose particular examples collected by observation have brought this art to perfection, and so in others. For what first taught astronomer's the number and course of the planets? Sense. What first told the natural philosopher that a lion feareth a cock, an elephant hateth a rhinoceros? Experience. What made the physician believe that rhubarb was good to purge, that eupatorium cured the infected liver? Daily observation in daily particulars. (146)

Indeed, if Luis-Martínez's Introduction were to be criticized, it would be for the absence of any appraisal of Fraunce's own contributions to English Ramism: his debts are clear, as are the development of his Ramist ideas, but his own legacy as a thinker is 
never given succinct treatment; rather it is left to the reader to draw his or her own conclusions. A case in point is Fraunce's tendency to simplify his sources: for if one of the main goals of Ramism was to order, systematize and simplify the diverse Aristotelian writings on logic and dialectic, Fraunce simplifies (and occasionally reorders) the simplifiers. Whether this is due to lack of energy or serves some philosophical agenda is a moot point which might have deserved some consideration.

If Ramism was markedly Protestant, it was also democratic where other rhetorics and poetics were aristocratic. One of its chief claims was that logic was the art of arts, the mental superstructure which enabled and gave backbone to other arts such as rhetoric and grammar, but also, as the passage quoted above attests, astronomy, natural philosophy, medicine, as well as humbler fields of activity like shoe-mending and carting (157). Whereas the Ciceronian myth of language as recycled by Thomas Wilson viewed eloquence as a gift of God bequeathed to a privileged few and, in Puttenham, none more privileged than Queen Elizabeth I, to the Ramist logic was natural in origin and, since all men can reason, universal. Of course, some men are better at it than others, and a few even excel; and it is the writings of the excellent which repay study and serve as models to help the rest of us improve. What is truly novel about Fraunce's Shepherds' Logic is that by implication, to the conventional list of Plato, Aristotle, Demosthenes, Cicero, Homer and Virgil it adds Edmund Spenser as a further "excellent," al beit vernacular, author. And it is in this regard that Luis-Martínez articulates his central thesis: "Fraunce's logic for shepherds is chiefly a book for poets and about poetry, a first-hand document showing how scholarly training in the arts of discourse could enlighten the composition and interpretation of poetic texts" (3). On the assumption that by "arts of discourse" (which on Ramist terms should strictly speaking be subordinate) is intended the art of logic, Luis-Martínez's contention is that Fraunce's work could offer guidance in what Ramists would call the "genesis" (composition) and "analysis" (interpretation) of poetic texts. By analyzing the "invention" and the "judgement" (or dialectic) of Spenser's The Shepherds' Calendar, potential poets would learn on the one hand how even the modest shepherd was possessed of natural reason and, on the other, how an excellent poet could, through language, render that pastoral logic to the pitch of perfection. Luis-Martínez further suggests that pastoral's 
conventional identification with the middle or plain style made it a particularly appropriate model of "plainness and accuracy of expression" (38), a point which might need to be qualified in the light of William Webbe's view in A D iscourse of English Poetrie (1586) that pastoral's "cloak of simplicity" was a ruse for fabricating rather more complex allegorical significances. ${ }^{1}$

Nonetheless, Luis-Martínez's thesis is plausible, yet there is one dimension to pastoral which is overlooked but may account for Fraunce's sustained engagement with the mode, as noted elsewhere (41). For as Louis A. Montrose has argued, literary pastoralism, which began to flourish in the last quarter of the sixteenth century, was a means of "covert political communication" and "a mode of ornamental self-display"; its pastorals were "coded performances in which a community of speakers and auditors, writers and readers, participate in a dialectic of inclusion and exclusion, in a process of social signification," one strand of which was the "metaphorical identification between otiose shepherds and leisured gentlemen" (1983, 427, 448, 431). Viewed in this light, Fraunce's logic may have been intended for courtiers sub specie shepherds, in which case the generally levelling aetiology of Ramist logic would come into conflict with the narrowly elitist ambition of Elizabethan pastoral. Another more straightforward and supplementary thesis might build on the parallels between the (almost exactly contemporaneous) vogues for Euphuism and pastoral and contend that Fraunce's recruitment of Spenser's work was merely an attempt to cash in on a bankable title: as with "Euphues," "anatomy" or "wit," any work with the word "shepherd" or, after Sidney, "Arcadia" on the title page (where authors' names were generally absent) was certain to attract an audience. ${ }^{2}$ Thus, the whole conception of The Shepherds' Logic might have been a plain, cynical and practical exercise in selfpromotion: sexy logic, sexy title... laughing all the way to patronage (with a bit of luck, but not in Fraunce's case).

As for The Shepherds' Logic itself, one suspects it is of less interest for what it says than for what it signifies as historical dust. If the

\footnotetext{
${ }^{1}$ Webbe's D iscourse, in a new critical edition by Sonia Hernández-Santano, has been published in the same series as the book under review (Webbe 2016). See also pages 239-41 in the current issue of Sederi for a review of that edition.
}

${ }^{2}$ On the publishing craze for Euphues, see Kesson (2014). 
Ramist-A ristotelian controversy reads today like an early modern precursor to any of the countless theoretical spats which beleaguer and often disfigure the academic project, at times Fraunce's own work is reminiscent of those jargon-heavy articles whose theoretical convolutions too often tend to obfuscate the blindingly obvious. It is also testimony to the pitfalls attending over-zealous taxonomy: some categories, for example, the argument "Of the thing caused" (76-79), are so capacious as to lose all analytical utility; while others, such as the arguments "Of the Subject," "Of the Adjunct" or "Of comparison (80-85, 92-93), or "Of the Like" (96-98), verge on the purportedly different and secondary arts of grammar and elocution, respectively. More crucially, logic's purported status as the "art of arts" relies on the question-begging premise that there can be thought without language ("reasoning may be without talking," 57), notwithstanding France's discussion of judgement (115), which practically conflates grammar with logic. Some of Fraunce's examples of false syllogisms in his chapter "Of the Elenchs" will raise a smile, my favorite being "God is everywhere;| Everywhere is an adverb;| Therefore [...]" (141-43). I leave the conclusion to the reader.

Luis-Martínez's edition comes complete with footnotes citing Fraunce's sources and three appendices, the first including pertinent extracts from The Lawyers' Logic, the second a catalogue of all the quotations from Spenser, and the third a comparative table of the contents of Fraunce's logical writings and Ramus/ Piscator's Dialecticae libri duo. The Index is full and helpful. All in all, for the foreseeable future Luis-Martínez's meticulous, ground-breaking edition will be the obligatory point of departure for all students and scholars with an interest in Fraunce's logical writings, as well as a providing a useful introduction to English Ramism in general. The book is a credit to English Renaissance studies in Spain, and LuisMartínez is to be congratulated.

A few errata in no way diminish the magnitude of LuisMartínez's achievement: "Macllmaine" in the Bibliography appears as "Mcllmaine" in the Index, and is spelt inconsistently in the Introduction; the tabulation of the argument of the adjunct (84) should read "Adjunct" rather than "Subject"; in the Glossary, "Modals" is out of al phabetical order. 


\section{References}

Kesson, Andy. 2014. John Lyly and Early Modern Authorship. Manchester: Manchester University Press.

McCormick, Sister Mary M., ed. 1968. A Critical Edition of A braham Fraunce's "The Shepheardes Logike" and "Twooe Generall D iscourses." Unpublished PhD dissertation. St Louis University.

Montrose, Louis Adrian. 1983. "Of Gentlemen and Shepherds: The Politics of Elizabethan Pastoral Form." English Literary H istory, 50 (3): 415-59.

Puttenham, George. 2007. The Art of English Poesy. Eds. Frank Whigham and Wayne E. Rebholz. Ithaca: Cornell University Press.

Scott, William. 2013. The M odel of Poesy. Ed. Gavin Alexander. Cambridge: Cambridge University Press.

Webbe, William. 2016 (1586). A Discourse of English Poetry. Ed. Sonia Hernández-Santano. MHRA Critical Texts. Volume 467. Cambridge: The Modern Humanities Research A ssociation.

How to cite this review:

Sell, Jonathan P. A. Review of Zenón Luis-Martínez, ed. A braham Fraunce. The Shepherds' Logic and Other Dialectical Writings (Cambridge: Modern Humanities Research Association, 2016). SED ERI 27 (2017): 255-61.

A uthor's contact: jonathan.sell@uah.es

Postal address: Facultad de Educación, $4^{a}$ planta, 24 - Universidad de Alcalá - Calle Madrid 1-19001 Guadalajara, Spain 


\title{
Richard McCabe 2016. \\ "Ungainefull Arte": \\ Poetry, Patronage, and Print in the Early Modem Era Oxford: Oxford University Press
}

\author{
Nora Rodríguez-Loro \\ U niversidad de Sevilla, Spain
}

Studies on patronage have generally been marked by a misconception of this system, since it has only been considered in economic terms. Alexander Beljame's $M$ en of Letters and the English Public in the Eighteenth Century (Le Public et les hommes de lettres en A ngleterre au dix-huitième siècle: 1660-1744) published in 1881, offered an inaccurate portrayal of aspiring professional authors as being entirely dependent on court favorites and praising them primarily for their nobility rather than their literary credentials. Similarly, in The Dedication of Books to Patron and Friend (1887) Henry Benjamin Wheatley referred to the dedication of plays as a literary fashion, which consisted in "praising men according to a scale of the more pay the more praise" (1887, 2). According to Wheatley, the dedications of the seventeenth century were marked by "slavish adulation," which is "something sickening to think of" (1887, 14). These scholars particularly criticized the praising of the patron, and they failed to understand that praise functioned as a literary convention.

Richard McCabe's "U ngainefull A rte": Poetry, Patronage, and Print in the Early M odern Era (2016) considers the importance of patronage to a writer's career, examining not only the rhetoric of dedications, but also how traditional modes of literary patronage were influenced by the challenge of print, as the economies of gift-exchange contended with those of the marketplace. To that end, he builds on the work of Pierre Bourdieu and associates patronage with systems of "generalized exchange" or "gift economy," although he stresses the importance of considering "how such concepts relate to that of the emergent book-market, and what the aesthetic implications of this relationship might be"(2). McCabe believes that the issue of patronage is often studied as purely contextual or biographical, while matters of self-presentation and self-reflexivity, 
which are vital to the literary expression of patronage, are marginalized. He attempts to supply a more nuanced view of the literary and social construction of patronal relationships, exploring the implications of print and book marketing and emphasizing the relationship between poet, patron, publisher, and reader.

Following the work of social anthropologists such as S. N. Eisenstadt and $\mathrm{L}$. Roniger, McCabe regards patronage as being part of a "macro-societal" context involving issues of hierarchy, social asymmetry, status anxiety, locality, kinship, credit, and obligation. In fact, literary patronage "was often exercised through presentation to a benefice or chaplaincy, appointment as private secretary or household tutor, or recommendation to some office of state, judicial appointment, or courtly sinecure" (3). Different forms of patronage may all converge, functioning through influence, connection, and direct power. The networks through which patronage was sought and gained were extremely diverse: "access to influence might be institutional (through schools, universities, Inns of Court, guilds), regional (connected to ancestral loyalties), religious (engaging with partisan or sectarian sympathies), familial (including extended groupings of clients and dependants as well as blood kin), or factional (exploiting or promoting divisions)" (4).

In McCabe's view, patronage was a dynamic social process endlessly negotiated and renegotiated between the parties concerned. The lack of a professional career structure or any formal mode of public recognition, forced writers to resort to various idealized paradigms in an attempt to flatter, or shame, prospective patrons into a sense of "obligation" (4). This "art of dedication" developed its own peculiar rhetoric with recurrent images, tropes, and themes, and allowed writers to establish what the ancient rhetoricians termed "ethos," an authorial worthiness designed to cultivate a privileged relationship with both dedicatee and readers (4). Through illustrious patronage poets might gain canonicity and by sponsoring a great talent patrons might accumulate "symbolic capital," which was an essential component of the "magnificence" expected of a person of rank (6).

All the parties involved struggled to "define the activity in mutually advantageous terms, typically involving altruism and beneficence on the one part and worthiness and gratitude on the other" (15). Authors attempted to define patronage in affective 
terms, refusing to discuss it in terms of economics or clientage. Poets had an acute interest in "representing themselves as 'friends' rather than 'clients', and their poetry as independent art rather than mercenary homage" (16). At the heart of the matter is "a negotiation between the patron's present celebrity and the poet's future fameand only through the latter can the patron's memory endure" (17). Moreover, the receipt of patronage conferred "authority" on talent: "the greater the patron's authority, the better the prospects; the highest authority might even confer the laurel crown" (17).

In addition, McCabe draws on examples from classical antiquity and Renaissance Italy to look at patronal relationships from the patrons' point of view. From this perspective, he observes, "patronage became the 'art of the powerful' and magnificence its aesthetic" (46). Magnificence functioned both as an expression of status and as a means to gain it. The terms in which the practice of dedications is customarily described transform it into "something incontestably sublime-magnificence, charity, patriotism, or simply noblesse oblige - the latter equally if not more important to those who were not of the ancient nobility or whose claims to preeminence were questionable" (46). While humanists encouraged the cultivation of letters as an expression of true nobility, patronage was commonly driven by an intense competition between families (such as the Sforza, Gonzaga, Medici, and Estensi).

McCabe further discusses the relevance of the advent of print for the patronage system. The printing press fundamentally altered the way in which poets thought about their careers and handled their relationships with patrons. It afforded authors the alluring economy of the open market, although it "threatened, at its worst, to downgrade the author to the level of hired penman, a mere employee of some printer or publisher" (7). There arose for the first time "the 'stigma' not of print per se, but of a remuneration from print that could not easily be represented as a 'gift' rather than a fee" (7). The expansion of print culture demanded "some mark of illustrious patronal recognition that distinguished an author from the rising number of writers promoted by the new medium" (7). The fear was that mass publication would destroy literary standards. Nevertheless, printing posed less of a threat to the system of patronage than might have been expected: "the new technology created new methods of policing and control, and publishers, no less 
than authors, needed the protection of powerful patrons" (8). In fact, printing fostered "a new set of social networks that radically altered conditions for the composition, editing, and reception of letters" (8). McCabe argues for the complementarity of patronal and print economies: "while illustrious patronage enhanced authorial status, both functioned as marketable commodities" (65).

Dedications extended patronal relationships to a wider audience. The circulation of a growing number of printed dedications "enhanced a patron's visibility while recommending the dedicator to a network of other influential writers, printers, and patrons" (65). The dedication was used to offset the "stigma" of hired labor by offering "gifts" to the public through the dedicatee, characterizing selling as gifting. Since the rhetoric of patronage served to idealize its economy, certain tropes were recurrent: dedicated works are "gifts," and unworthy of the recipient; the gesture is made as a "token" of love, service, friendship, respect, or gratitude; social disparity notwithstanding, author and patron are linked by bonds of affection, kinship, origin, or loyalty; the giver seeks "protection," "favor," or "acceptance" and relies on the recipient's courtesy or grace; association with the dedicatee will lend luster to the writer because he or she is the true arbiter of worth; in supporting, protecting, favoring, or accepting the author's tribute, the dedicatee acts in the public as well as the private interest; dedicatees are noble, gentle, benevolent, learned, fair-minded, patriotic, godly, or loyal, a credit to their class, court, guild, arms, or blood" (73). In addition, assertions of sincerity, loyalty, impartiality, and veracity are common topoi aimed at establishing an orator's ethos, or moral character, and consequently common to eulogist and flatterer alike (74).

McCabe explains that the peculiarity of the art of dedication is that it embodies panegyric in epistolary form. A major purpose of the epistle was to facilitate acceptance of the gift by fashioning the recipient in idealized terms. For this reason, there are appeals, for instance, to honor, courtesy, friendship, kinship, grace, loyalty, and favor, as well as negotiations between familiar and formal modes of address. An illustrious patron bestows luster on both writer and work, and when he or she is alleged to have "accepted" an author's approach, the correspondence could be imagined as reciprocal (79). McCabe considers further topoi of dedicatory writing, such as the 
"humility topos," which derives from the social disparity between author and patron, signaled in the blazoning of titles, formality of address and conventionally apologetic tone (83). In addition, as McCabe explains, "the function of rhetoric is to persuade, and that of persuasion to attain a clearly defined end" (85). An appeal for support may be expressed in terms of public utility, with an emphasis on the cultural, moral, or political "use" of an author's work as well as establishing some form of "fictive kinship" with the dedicatee, but in all cases, one needs to interrogate convention for intent (85).

The second section of the book deals exclusively with literary patronage in Renaissance Italy. McCabe traces the development of Petrarch's attitudes towards patronage, examines his association with, among others, Robert of Naples, Cola di Rienzo, the Colonna, the Visconti, and the Emperor Charles IV, and studies the presentation of patronage in the Africa and a number of verse and prose epistles (108-21). He also considers Ariosto's literary career, contrasting his attitudes to his Estensi patrons both in script and print, and examining the various strategies used to ironize an apparently straightforward eulogy (123-32). Finally, McCabe relates Tasso's uneasy relationship with Alonso II d'Este and its implications for his major writings, particularly the A minta and G erusalemme Liberata (136-45).

The last section explores English literary patronage, from 1500 until 1625, considering the careers of Caxton, Skelton, Elyot, and Udall. McCabe traces the advent of the printer/ publisher as an increasingly central figure in canon formation, and in the production of new vernacular works (150-67). He also studies the impact of female sovereignty on traditional modes of patriarchal patronage, comparing Elizabeth to Mary Tudor. He analyses the various strategies that Queen Elizabeth employed to maintain her independence from the different factions attempting to appropriate her authority, or control her image (173-93). An examination of the dedications addressed to the Earl of Oxford and the Countesses of Pembroke and Bedford demonstrates the extent to which coteries operated in Elizabethan and Jacobean England (199-211). Drawing on the fact that membership of elite groups conferred considerable status on emerging authors, he argues that the notion of coterie might be essential for commercial as well as creative reasons. With 
regards to career trajectories, he illustrates how three very differently positioned poets (Gascoigne, Spenser, and Daniel) negotiated patronage and print, "professional" careerism, and "laureate" status (229-66). Furthermore, McCabe discusses the implications for literary patronage of the accession of James I, who had an already well-established print persona (288-309). To the inherent difficulties of the production of courtly literature, the Stuart accession added those of a rival court, for Prince Henry cultivated a different literary aesthetic. A final chapter examines the consequences of the creation of a poet laureateship by Charles II, and its effect on the professional career and public reputation of John Dryden (314-20).

In conclusion, McCabe offers a comprehensive analysis of literary patronage in the Renaissance, with particular attention to the rhetoric of dedication. In it, he points out the impact of print on the traditional modes of literary patronage, when the economy of giftexchange was challenged by the marketplace. His work is an essential resource for all scholars interested in literary patronage and its rhetorical conventions.

\section{References}

Beljame, Alexandre. (1881) 1948. M en of Letters and the English Public in the Eighteenth Century. Ed. Bonamy Dobrée. London: K. Paul, Trench, Trübner.

Wheatley, Henry Benjamin. 1887. The D edication of Books to Patron and Friend. London: Elliot Stock.

How to cite this review:

Rodríguez-Loro, Nora. Review of Richard McCabe. "Ungainefull Arte": Poetry, Patronage, and Print in the Early Modern Era (Oxford: Oxford University Press, 2016). SEDERI 27 (2017): 263-68.

A uthor's contact: nrodriguez6@us.es

Postal address: Dpto. de Literatura Inglesa y Norteamericana - Universidad de Sevilla -

C/ Palos de la Frontera s/ $n$ - 41004 Sevilla, Spain 


\title{
Thomas 0'Connor. 2016. Irish Voices from the Spanish Inquisition: Migrants, Converts and Brokers in Early Modern Iberia Basingstoke: Palgrave-M acmillan.*
}

\author{
Óscar Recio Morales \\ U niversidad Complutense, M adrid
}

Irish Studies enjoys a privileged position in the current historiographical renewal of the study of foreigners in early modern Spain and Spanish America. However, no monograph or collection has been dedicated to the relationship between the Irish "nation" (using the term of the period) and the Spanish Inquisition. This book attempts to fill this gap by including the twofold experience of those individuals who suffered the persecution of the Holy Office (Santo 0 ficio) and those who worked for its institutions such as interpreters, translators, informers, family relatives, and theological experts. The research findings are extraordinary.

The three main achievements of this work are the following: first, the balance between the historical context and the fragmentary, yet rich, variety of inquisitorial cases. On the one hand, the dozens of cases examined are perfectly integrated within a narrative where "great international politics" succeed in determining, in many cases, the trials' outcomes and their consequences for the accused; at the same time, inquisitorial sources enable us to study the personal life and professional career of the accused, which endows the narrative with an extraordinary liveliness. The second achievement is the extensive use of documentary sources from Spanish and Portuguese archives, as well as the handling of multilingual or, if one prefers, Continental bibliography. This would seem obvious in this scholarly endeavor, were it not for the fact that there are still English-speaking authors who misuse the fragmentary and dated Calendar of State Papers when referring to Spain, and others who only make use of sources and studies written in English. Third, the presence of Portugal-especially of Lisbon-in this book is especially

\footnotetext{
${ }^{*}$ Review translated by María J. Sánchez-de-Nieva.
} 
noteworthy, since Irish Studies related to the Iberian Peninsula have tended to focus almost solely on Spain and Spanish America.

This work is divided into three chronologically organized parts (sixteenth, seventeenth, and eighteenth centuries) in a long durée perspective which proves appropriate to address such a complex issue for the first time. The first part (sixteenth century: Chapters 1, 2 , and 3) examines the first steps taken by the Irish in acting as gobetweens between the British and the Spanish empires, as well as their ability to elaborate an ad hoc discourse in their relationship with the Inquisition. This "persecution narrative"-which would repeat itself over the next two centuries-emphasized the Catholic nature of Ireland and the forced conversions of individuals to the state Anglican Church, either by force or by necessity (to practice a profession). According to the Thomas $\mathrm{O}^{\prime}$ Connor it was therefore a superficial conversion to Catholicism rather than a sincere act. This was the standardized narrative Inquisition judges expected to hear. The Inquisition was aware of Ireland's ethno-religious complexity, but decided not to deal with it (neither did it question the spaces of religious freedom left in London, where many Irish people lived before they moved to Spain). Thus judges did their job, there was room for reconciliation, and usually the criminal process did not pursue matters further. It was only when this standardized discourse was broken that the accused was in real danger. This is what happened to one John Martin, a native of Cork, who had been living in Mexico for many years. He did not use the usual intermediary translator, he defended himself in Spanish, and he was stubborn in his answers. What seemed like a clear example of acculturation and earnest collaboration ended in tragedy: he was executed in 1575.

The formal entry of Irish clerics into the structures of the Inquisition did not take place until the institutionalization of a network of Irish colleges in Spain and Portugal, as noted by the author. However interesting this thesis may be, it means a significant qualitative leap which would have benefited from a more detailed explanation: the internal disputes between Franciscans close to the Gaelic world and Old-English extraction Jesuits were unlikely to be the best combination through which to collaborate with the Holy Office. Nor were some well-known cases of theological dispute in the Castilian universities that ended up involving some Irish 
teachers. Although quite well known, the case of the teacher at the University of Santiago de Compostela, Patrick Sinnott, could have led the author to a further examination of the conflict between the new academic perspectives and the Inquisition (82-83).

In the second part of the book (seventeenth century: Chapters 4, 5 and 6), the Holy Office's practical need for Irishmen is clearly established: some merchants worked as interpreters for Inquisition officials on the inspection of foreign ships (73-76), while clerics and other members of religious orders reconciled Irish Protestant recruits who arrived in Spain in numbers in the 1640s. The last part of chapter 4 (Reconciling I rish M uslims, 83-86) is particularly interesting as it deals with an unheard episode in the Mediterranean history of the Irish. In chapter 5 (devoted to America), it is al so fascinating to learn of the relationship between the Irish Jesuit Michael Wadding, rector in 1628 of the college San Jerónimo de Puebla (Mexico) and theological examiner for the Inquisition, and the famous reformer bishop and visitador general (inspector) of New Spain, Juan Palafox y Mendoza (1600-1659). Mexico was also the setting of one of the key cases of the Inquisition, that of William Lamport, a creature of Gaspar de Guzmán, the count-duke of Olivares (1587-1645), King Philip IV's right-hand man. The author provides new information on the case up to the execution of Lamport in 1659, this case demonstrating once again that an open, outright confrontation with the Inquisition could only harm the accused: occasionally even, as was the case with Lamport, the process could turn into a political trial.

The third and last part of the book (1701-1713) opens with the new possibilities that the Spanish War of Succession (1701-1713) offered the Inquisition thanks to the presence of foreign soldiers in the peninsula, and specifically Irish Protestants. It highlights the founding of the Casa de Catecúmenos by the Inquisition commissary in Madrid, where English and Irish clerics monopolized the reconciliation of heretics. In chapter 8, devoted to the golden age of Irish merchants in Spain, the author reveals an interesting thesis on the close collaboration with the Inquisition in order to explain part of their business success: during the War of Succession the Irish occupied the place of English merchants in Spanish ports and this collaboration with the Holy Office secured them a privileged place in Málaga, Bilbao, the Canary Islands and Cádiz. In chapter 9 it is 
interesting to note the potential threat that the Inquisition posed to talent mobility and the incorporation of foreign scientists into the industrial and military modernization programs in Spain. Although many Irish benefited from being Catholic, many of mixed origin or married to followers of a different religion were subjected to the same reconciliation process as foreign soldiers were. Finally, chapter 10 examines the twofold role of Irish women in their relationship with the Inquisition as subjects of reconciliation, on the one hand, and as denouncers, witnesses, and interpreters, on the other. Women suffered from the Inquisition's social control, but they also learned to take advantage of it, especially denouncing husbands accused of bigamy and abandonment in marriage. Testimonies of a group of Irish women sexually molested by an influential Irish cleric at Court, John Lacy, resulted in his definitive exile from Madrid in 1754, the loss of all of his titles and honors, and compulsory rehabilitation in a local religious house, Lacy was also ordered to pay all costs.

In conclusion, we have here a reference work on a topic that, as noted by the author himself, opens new research opportunities on other groups of foreigners in Spain, such as the English and Scots. Unfortunately, it is a shame that such an outstanding monograph, advancing as it does interest in Irish Studies in Spain and making use of so many institutions and public archives, is somewhat expensive, and perhaps beyond the reach of many scholars interested in it.

How to cite this review:

Recio Morales, Oscar. Review of Thomas O'Connor. Irish V oices from the Spanish Inquisition: M igrants, Converts and Brokers in Early Modern Iberia (Basingstoke: Palgrave-Macmillan, 2016). SED ERI 27 (2017): 269-72.

A uthor's contact: orecio@ucm.es

Postal address: Dpto. de Historia Moderna - Profesor Aranguren, s/ n. Edificio B Universidad Complutense de Madrid - Ciudad Universitaria - 28040 Madrid, Spain 


\title{
Performance Reviews*
}

\section{The G lobe to G lobe Hamlet Tour: \\ A Celebratory Performance in Elsinore. \\ Elsinore Conference 2016 \\ Shakespeare, The Next 400 Years \\ Kronborg Castle, Helsingør \\ 21 A pril 2016}

\author{
Remedios Perni \\ U niversidad de A licante, Spain
}

\begin{abstract}
CAST AND CREATIVE TEAM
Cast: Keith Bartlett, John Dougall, Ladi Emeruwa, Phoebe Fildes, Miranda Foster, Naeem Hayat, Beruce Khan, Tom Lawrence, Jennifer Leong, Rãwiri Paratene, Matthew Romain, Amanda Wilkin.

Directors: Dominic Dromgoole and Bill Buckhurst.

Designer: Jonathan Fensom.

M usic: Laura Forrest, Bill Barclay.

Produced by Shakespeare's Globe.
\end{abstract}

This production of Globe to Globe Hamlet at Hamlet's castle in Elsinore was the concluding show of the two-year-long tour of the Shakespeare's Globe project before the company's return to the Globe in London, where the tour had opened on 23 April 2014. Sixteen actors and actresses had travelled across the seven continents

\footnotetext{
* Sederi collaborates with www.ReviewingShakespeare.com, the first website devoted to scholarly reviews of and writing about worldwide Shakespearean performance (theatre, film, TV) for a general audience. Reviews about Shakespearean performances worldwide submitted for publication to Sederi are sent to the team of specialists managing ReviewingShakespeare, and they will decide whether the review might also be suitable for publication on their webpage. Inversely, a selection of reviews of Spanish and Portuguese productions of Shakespeare's plays submitted to ReviewingShakespeare are also considered for publication in Sederi.
} 
to confirm Dominic Dromgoole's idea that "Shakespeare can entertain and speak to anyone, no matter where they are on earth" (Globe to Globe Web 2016). Indeed, after touring throughout 197 countries and performing in front of hundreds of thousands of spectators, the mission had been accomplished. The tour was even granted UNESCO patronage for its commitment to different local communities and its promotion of culture, and many people had applauded this wonderful initiative. Besides, the show in Elsinore Castle aimed to celebrate Shakespeare's double anniversary; namely, 400 years since his death and 200 years since the beginning of the oldest Shakespeare performance tradition at Kronborg. But what made the $21^{\text {st }}$ of April in Helsingør most special was that the production was double as well. There were two occasions to see the play: one of them was public, in the afternoon, and the other one was private, in the evening. This last performance welcomed the Shakespeareans taking part in the 2016 Elsinore Conference (entitled Shakespeare: the $N$ ext 400 Y ears) and some special guests, the Queen of Denmark among them. While the royal visit could have been remembered as a mere anecdote, the presence of the queen actually contributed to the meta-theatrical dimension of Globe to $\mathrm{Gl}$ lobe $\mathrm{H}$ amlet, which also deployed various challenging and ironic twists with regard to Shakespeare's play.

The meta-theatrical perspective adopted by the touring company could be seen even before the performance started, as the portable stage they had been carrying all around the world was a theatrical survival kit consisting, basically, of a structure made of sticks, a red curtain, three or four trunks on the stage and musical instruments hanging from the wall and ready to be played by any of the performers. There was no simulation, no intention of hiding the theatrical structure. Actually, these actresses and actors recalled the Hamlet-directing-the-actors scene, and the aesthetics of the whole play seemed to pay homage to The M ousetrap: they were travelling actors in a travelling play performing changeable roles and perspectives on the old text. Such a sense of movement and fresh spontaneity resulted in one of the most humorous versions of $\mathrm{H}$ amlet onstage, turning the tragedy into a comedy at some points, especially during the first part.

Naeem Hayat, born in East London of a Pakistani family, played Prince Hamlet, providing the mythical character with a new de- 
centralized and post-colonial identity that was far from the typically masculine solemnity of other Hamlets, focusing on the (anti-) hero's vulnerability and paranoia instead. By contrast, Ophelia (Phoebe Fildes) appeared as a girl full of life in a pinkish flowery dress - as those that can be found at Brick Lane or Spitalfields Market in London. In fact, the characters' costumes contributed to the joviality of their performance, as these were designed as a hybrid between the Middle Ages and the postmodern hipster aesthetics. It is also worth mentioning Keith Bartlett's take on Polonius and his hilarious and onomatopoeic performance, which made the audience laugh all throughout the first part of the play, and the Claudius-Gertrude tandem (John Dougall and Miranda Foster), both dressed in velvet red capes, as if to note their complicity.

In many senses, this production offered a simplified iconic version of our over-complicated readings of $\mathrm{H}$ amlet, making things clear from the beginning. To stage a play is to make choices, and this $\mathrm{H}$ amlet went for more straightforward meanings than academic interpretations. For instance, if Claudius' and Gertrude's complicity was shown through their dress, Ophelia and Polonius's closeness was highlighted through their speech, as they would speak many lines simultaneously. Ophelia's "dishonesty" towards Hamlet is shown through her unambiguous collaboration with her father and the court in spying on the supposedly mad prince: while he is asking her the well-known accusatory "Are you honest?," we can see Polonius hiding behind the curtain, and Hamlet looking at the curtain itself and guessing someone is there when hearing Polonius cough. We can also clearly feel Hamlet's psychotic misogyny when he shakes violently both Ophelia and Gertrude; the former, during the Go-to-a-nunnery scene, and the latter in the queen's chamber, but only until the top patriarch, the Ghost father, tells him to stop. There is no Oedipus complex this time, but only plain family matters. Of course, this sort of malleable simplification allowed the company to focus on the comic side of the play as well as to adopt an interesting variety of cultural tics and expressions from the different parts of the world where the play was staged during two years; on this specific occasion, for example, they introduced some Danish wordplay and expressions and jokes on Danish drinking habits.

One of the climactic moments of this party-like production of $\mathrm{H}$ amlet, as mentioned above, was the staging of the play-within-the- 
play, The M ousetrap. The audience of the play was the real audience that evening at Kronborg Castle, while Ophelia and Hamlet were seeing it from the sidelines. John Dougall, who was playing Claudius, also acted Gonzago, while Miranda Foster (also Gertrude) and a younger man were to "kill" him with poison. The red curtain was used as a makeshift element. When it opened, we could see the "acted" scene; when it closed and opened again, we saw the same actors with different robes, embodying Gertrude and Claudius following the plot in horror. This game of simultaneity provided the audience at Kronborg with a feeling of identification understood in different ways: first, we identified with the imaginary audience of The M ousetrap; then, we identified the mocked characters with the queen and king in $\mathrm{H}$ amlet; moreover, we understood that the prince was unmasking them very straight-forwardly. Finally, the most brilliant touch-if not the most hilarious-was provided by the presence of Queen Margrethe of Denmark herself, as Naeem Hayat was staring at her and her entourage when reciting the words about "guilty creatures sitting at a play" (H amlet, 2.2.524).

But not everything about this $\mathrm{H}$ amlet was parody and humor. While the first part of the play was performed in the depicted comic fashion, the second one, after an interval, developed into the tragedy that any $\mathrm{H}$ amlet fan would expect. Very interestingly, Ophelia was the one in charge of connecting comedy and tragedy; actually, she was the thread linking all major characters, and of course this has not been the first time that her role in providing a common tragic space has been highlighted in a production.

When the second part started, Ophelia was already deranged, dressed in white and singing beautiful songs. We had seen her playing drums and other instruments before the interval. Now, she was mentally gone, close to sleepwalking, and the other characters could not but contemplate her distress. Then, a very sad Gertrude narrated her death (a typical option in received productions of the play), and Laertes appeared onstage, a bit overreacting, while the other characters-all but Hamlet, who was still on his way to England- mourned Ophelia's demise.

The cemetery scene also reflected the changeable and hybrid nature of this production, as it presented a female gravedigger in conversation with Hamlet and Horatio. Nonetheless, the most fascinating moment of this scene takes place when Ophelia enters 
singing to her own funeral and proceeds to lie down and be buried (only below a brown mantle). The scene shifts from this moment onwards are quite agile and quick. Soon after Ophelia's burial, the duel between Hamlet and Laertes takes place and all the characters are dead by poison.

However, what started as a comedy could not end as a complete tragedy. Once Hamlet speaks his last words and a new beginning with Fortinbras is announced, reaching the conclusion of the play, Ophelia comes back to the stage unexpectedly, singing lively and resuscitating all the corpses as she is dancing onstage. This way, this production closing the biggest theatrical celebration of Shakespeare's anniversary, seems to inform us that the rest is not silence. Indeed, since Hamlet's first collapse, there has been much to say and to perform, much to sing and to commemorate. Indeed, it would be fair to say that the Shakespeare's Globe has magnificently contributed to our happy celebration of The Bard over the last two years. Bravo!

\section{References}

Globe to Globe. 2016. "About the Project." Accessed August, 2016. http:/ / globetoglobe.shakespearesgl obe.com/ hamlet/ about-the-project.

Shakespeare, William. 2005. Hamlet. Edited by Ann Thompson and Neil Taylor. London: Arden Shakespeare.

How to cite this review:

Perni, Remedios. Review of The Globe to Globe Hamlet Tour: A Celebratory Performance in Elsinore. Elsinore Conference 2016: Shakespeare, The N ext 400 Y ears. SEDERI 27 (2017): 273-77.

A uthor's contact: reme.perni@ua.es

Postal address: Facultad de Filosofía y Letras - Universidad de Alicante - Carretera de San Vicente del Raspeig s/ n - 03690 San Vicente del Raspeig - Alicante, Spain 